\title{
Suggestions for Introducing Creative Entrepreneurship Education into China's Design Education
}

By

\author{
Weiwen $\mathrm{Yu}$
}

A thesis submitted to the Faculty of Graduate and Postdoctoral Affairs in partial fulfillment of the requirements for the degree of

Master of Design

in

Industrial Design

Carleton University

Ottawa, Ontario

(C) 2015, Weiwen $\mathrm{Yu}$ 


\begin{abstract}
In China, creative industries are evolving, but creative entrepreneurship education is undeveloped. In order to propose an approach for introducing creative entrepreneurship education into design education in China, this study utilized a mixed method to investigate designers' entrepreneurial aspirations, motivations, and intentions as well as the factors that drive designers to develop their entrepreneurial potential. It also provides suggestions for developing creative entrepreneurial programs for design graduates. Interview and survey data were collected from Chinese designers and analyzed through a descriptive and a statistical procedure. The analyses suggested that Chinese designers' entrepreneurial intentions (EIs) are positive but not strong enough to motivate them to start their business. The statistical analysis uncovered eight main motivational factors and clustered five types of creative designers. Three of the creative clusters would benefit from creative entrepreneurship education. Moreover, the analyses suggest creative entrepreneurial programs should be established by design schools at regular public universities.
\end{abstract}

Keywords: Creative Industries in China, Creative Entrepreneurship, Design Education in China, Entrepreneurship Education in China, Entrepreneurial Intentions 


\section{Acknowledgements}

Without significant people's aid, it would have been impossible to complete this study. Firstly, I need to thank you my co-supervisors, Professor Bjarki Hallgrimsson and Dr. Mika Westerlund. They provided enormous support and help, allowing me to accomplish this study. Secondly, I need to thank Mike for his little favor. Meanwhile, Dr. Lorenzo Imbesi's hints helped me with my study as well. Finally, I need to thank my friends, my parents in particular, and those whose names cannot be presented in this acknowledgement. 


\section{Table of Contents}

$\begin{array}{ll}\text { Abstract } & 2\end{array}$

Acknowledgements $\quad 3$

$\begin{array}{ll}\text { List of Tables } & 7\end{array}$

$\begin{array}{lr}\text { List of Figures } & 8\end{array}$

Glossary of Terms 11

$\begin{array}{ll}1.0 \text { Introduction } & 18\end{array}$

$\begin{array}{ll}1.1 \text { Background and Needs } & 20\end{array}$

1.2 Demystifying Problems 22

1.3 Purposes of the Study 24

1.4 Research Questions 25

1.5 The Scope of the Study 25

$\begin{array}{ll}1.6 \text { Delimitations } & 26\end{array}$

$\begin{array}{ll}2.0 \text { Literature Review } & 28\end{array}$

$\begin{array}{ll}\text { 2.0.1 Defining design } & 28\end{array}$

2.1 Design in China 28

2.1.1 A brief history of China's design 29

2.1.2 Endemic problems in China's design education 30

2.1.3 China’s design milieu $\quad 35$

2.2 Creative Industries in China 37

2.3 Entrepreneurship and Entrepreneurship Education 39

2.4 Entrepreneurial Education in China $\quad 42$

2.5 Creative Entrepreneurship or Design Entrepreneurship 44

2.6 Blending Entrepreneurship and Design in Education 45

2.7 Two Case Studies $\quad 47$

2.7.1 Student placement for entrepreneurs in education (SPEED) in the UK 48

2.7.2 Design direct: How to start your own micro brand 51

2.8 Rationales for Creative Entrepreneurship in Design 53

2.9 Entrepreneurial Aspiration, Motivation, Intention, and Driver (EAMID) 58

2.9.1 The theory of planned behaviour (TPB) 58 
2.9.2 Entrepreneurial intentions (EIs) $\quad 60$

2.9.3 The relation between entrepreneurial motivations and drivers $\quad 61$

2.9.4 Different levels of entrepreneurial intentions (EIs) 64

$\begin{array}{ll}3.0 \text { Methodology } & 68\end{array}$

3.1 Research Questions Review $\quad 69$

3.2 Qualitative Method - Expert Interviews 70

$\begin{array}{ll}\text { 3.2.1 Sampling and participants } & 70\end{array}$

$\begin{array}{ll}\text { 3.2.2 Procedures and data } & 71\end{array}$

3.3 Questionnaire (Quantitative Method) 71

3.3.1 Sampling and participants $\quad 73$

$\begin{array}{ll}\text { 3.3.2 Procedures and data } & 73\end{array}$

$\begin{array}{ll}4.0 \text { Finding and Analysis } & 75\end{array}$

4.1 Findings from Interviews $\quad 75$

4.1.1 Entrepreneurial aspirations and intentions $\quad 75$

4.1.2 Entrepreneurial impediments and obstacles 76

4.1.3 Attitudes about creative entrepreneurship and design education $\quad 78$

4.2 Findings from the Survey $\quad 80$

4.2.1 General analysis - Frequency distribution (FD) 81

$\begin{array}{ll}\text { 4.2.2 Factor analysis } & 87\end{array}$

$\begin{array}{ll}4.2 .3 \text { Cluster analysis } & 90\end{array}$

$\begin{array}{ll}\text { 4.2.4 Crosstabs analysis } & 93\end{array}$

$\begin{array}{ll}5.0 \text { Conclusions } & 112\end{array}$

$\begin{array}{ll}5.1 \text { Discussions } & 113\end{array}$

5.1.1 Discussion for general entrepreneurial intentions and motivated drivers

5.1.2 Discussion for specific designers' entrepreneurial behaviour $\quad 116$

$\begin{array}{ll}\text { 5.1.3 Discussion for design education } & 120\end{array}$

5.1.4 Discussion for future suggestions about creative entrepreneurial $\begin{array}{ll}\text { programs } & 122\end{array}$

$\begin{array}{ll}\text { 5.2 Limitations } & 125\end{array}$ 
References

Appendix 3

Appendix 5 


\section{List of Tables}

Table 1. 100 Creative Enterprises in the SPEED’s Program 50

Table 2. Factors and factors loading based on variable sets C and D 88

Table 3. Five types of designers based on their entrepreneurial intentions 91 


\section{List of Figures}

Figure 1. The three big economic regions (yellow) in China. 21

Figure 2. The brand profile. $\quad 52$

Figure 3. The model of creative entrepreneurship education. $\quad 54$

Figure 4. The new model for design education in China. $\quad 57$

Figure 5. The model of the theory of planned behaviour. 59

Figure 6. An adapted linear illustration of beliefs to behavior. $\quad 60$

Figure 7. The model and contexts of intentionality. $\quad 61$

Figure 8. The model in scales' level of entrepreneurial intention (EI). 65

Figure 9. Two types of individuals. $\quad 66$

$\begin{array}{ll}\text { Figure 10. The methodological structure. } & 69\end{array}$

Figure 11. The values of respondents based to gender. 82

Figure 12. The values of respondents based to age. $\quad 82$

Figure 13. The values of respondents based to type of school. 83

Figure 14. The values of respondents based to type of student. 83

Figure 15. The values of respondents based to education status. $\quad 84$

Figure 16. The values of respondents based to type of company. 84

Figure 17. The values of respondents based to position. 85

Figure 18. The values of respondents based to years of working. 85

Figure 19. The values of respondents based on the most influential persons. 86

Figure 20. The values of respondents' entrepreneurial aspirations. 86

Figure 21. The crosstabs of type of school and gender (A03* A01). 94

Figure 22. The crosstabs of education status and gender (A05* A01). 94 
Figure 23. The crosstabs of education status and the final question (A05* F).

Figure 24. The crosstabs of entrepreneurship and gender (B01* A01).

Figure 25. The crosstabs of entrepreneurship and age (B01* A02).

96,119

Figure 26. The crosstabs of entrepreneurship and type of school (B01* A03).

Figure 27. The crosstabs of entrepreneurship and education status $(\mathrm{B} 01 * \mathrm{~A} 05)$.

98,120

Figure 28. The crosstabs of entrepreneurship and type of company (B01* A06).

99,117

Figure 29. The crosstabs of entrepreneurship and years of working (B01*A09).

99,119

Figure 30. The crosstabs of start-up categories and gender $(\mathrm{B} 03 * \mathrm{~A} 01)$.

100,118

Figure 31 . The crosstabs of the likelihood of creating venture and age (B04* A02).

Figure 32. The crosstabs of the likelihood of creating venture and type of company (B04* A06).

Figure 33. The crosstabs of the likelihood of creating venture and years of working (B04* A09).

Figure 34. The crosstabs of the likelihood of creating venture and clusters (B04* Clusters). 104

Figure 35. The crosstabs of the obsolete design courses and gender $(\mathrm{E} 01 * \mathrm{~A} 01)$.

Figure 36. The crosstabs of the obsolete design courses and type of student (E01* A04). 105

Figure 37. The crosstabs of the yearning for design methods and education status (E05* A05).

Figure 38. The crosstabs of the yearning for design methods and type of company (E05* A06).

Figure 39. The crosstabs of the yearning for skills and knowledge about software practice and education status $(\mathrm{E} 06 * \mathrm{~A} 05)$. 
Figure 40. The crosstabs of the yearning for skills and knowledge about project management and gender $(\mathrm{E} 08 * \mathrm{~A} 01)$.

Figure 41. The crosstabs of the yearning for skills and knowledge about project management and education status $(\mathrm{E} 08 * \mathrm{~A} 05)$.

Figure 42. The crosstabs of the yearning for skills and knowledge about marketing and education status $(\mathrm{E} 09 * \mathrm{~A} 05)$.

Figure 43. The crosstabs of difficulties of finding jobs for young design graduates and age (E14 * A02).

Figure 44. The crosstabs of venture creation because of difficulties' finding jobs and age (E16 * A02). 


\section{Glossary of Terms}

The Bohai Economic Rim (BER) refers to an economic area that includes cities in Hebei

Province, Shandong Peninsula, and other cities around the Bohai Bay but are socioeconomically influenced by Beijing, the capital city, and a municipality, Tianjin (Zhang, 2011).

Cluster Analysis (CA) refers to a mathematical method for grouping similar objects in a set from numerable data (Romesburg, 2004).

Creative Cities refers to cities that carry identities as global cities' that influnence finances, business, politics, and professional services or offor special cultural content, torurism, and entertainment; meanwhile, they have resources that can support the development of societal amenity, techonological, innovative, cultural, and creative indsutries (Flew, 2012).

Creative Class refers to professionals who are engaging in, contributing to, participating in, working for, and operating creative industries. They produce valuable outputs by using their talents. These professionals are artists, designers, architects, writers, editors, programmers, filmmakers, musicians, etc. (Florida, 2002; UNCTAD, 2008).

Creative Clusters "are groupings of manufacturing and business activities consisting largely of creative enterprises" (Li, 2011, p. 104).

Creative Economy refers to "the interface between creativity, culture, economics and technology as expressed in the ability to create and circulate intellectual capital, with the potential to generate income, jobs and export earnings while at the same time promoting social inclusion, cultural diversity and human development" (Newbigin, 2010, p. 24).

Creative Entrepreneurs are talented entrepreneurial individuals who believe and utilize creativity to generate wealth and socioeconomic values, and they sustain this activity to provide creative products and services for society (Howkins, 2007; UNCTAD, 2008). 
Creative Entrepreneurship refers to the procedure of creating, developing, operating, and manging a business by creative entrepreneurs in creative sectors or creative industries.

Creative Industries "are the cycles of creation, production and distribution of goods and services that use creativity and intellectual capital as primary inputs; constitute a set of knowledge-based activities, focused on but not limited to arts, potentially generating revenues from trade and intellectual property rights; comprise tangible products and intangible intellectual or artistic services with creative content, economic value and market objectives; are at the crossroad among the artisan, services and industrial sectors; and constitute a new dynamic sector in world trade" (UNCTAD, 2008, p. 13).

Cross-Tabulation Analysis (CTA) refers to contingency table analysis, or contingency analysis, which is intended to "test hypotheses about how some variables are contingent upon others, or how increases in one affects increases, decreases or curvilinear changes in others" (White \& Korotayev, 2004, p. 1). In practice, it is used to "compare two categorical variables by showing a table with the classes of one variable as the rows and the classes of the other variable as the columns" (Pontius \& Cheuk, 2006, p. 2).

Design Entrepreneurship "is the collection of correct skills and abilities to develop the right ideas and market them as the successful design products" (Gunes, 2012, p. 65).

Entrepreneurship is an activity that creates new enterprises and economic development that carries innovation, employment, and social values (Acs, Desai, \& Hessels, 2008; Low \& MacMillan, 1988).

Entrepreneurship Intentions (EIs) refers to the consciousness that exists in entrepreneurs' minds for new venture creation (Bird, 1988; Boyd \& Vozikis, 1994). 
Factor Analysis (FA) refers to "a collection of methods used to examine how underlying constructs influence the responses on a number of measured variables" (DeCoster, 1998b, p. 1). Foreign Direct Investment (FDI) refers to an investment made by foreign companies or organizations instead of domestic investors (Investopedia, LLC., 2015); In China, this term is used to describe foreigners' investments.

Foreign Joint Ventures (FJVs) refers to a partnership in doing business between foreign and domestic investors that cooperatively share business activities, management, and outcomes in China (Government of Canada, 2015).

Foreign Owned Enterprises (FOEs) refers to organizations and enterprises entirely owned by foreign investors or owners in China. There are no Chinese partners involved the ownership or investment of these enterprises (Huang, 2013).

Frequency Distribution (FD) refers to "the summary of the values of a variable based on the frequencies with which they occur" because it is to present "how the values of the variable are distributed across all of the cases in the data" (Colwell \& Carter, 2012, p. 40).

Gaokao (高考)—University Entrance Examination, National Matriculation Examination, National College Entrance Examination in China (UEEC, NMEC, NCEEC) — refers to a national level academic examination for senior high-school students to register before they can enroll in any level of college or university in China (Davey, Lian, \& Higgins, 2007).

Gaige Kaifang (改革开放) refers to the policy implemented by the Eleventh Central Committee of the Chinese Communist Party in December 1978. It was intended to transform China's planned economy into a transition economy and to open the market to foreign investors (Huenemann, 2013). 
Guanxi (关系) refers to a Chinese socio-cultural term. It is a socio-beneficial relationship between two independent individuals, and it relies on continual transactions between these two individuals (Li \& Liu, 2010; Taormina \& Lao, 2007; Yeung \& Tung, 1996).

Interdisciplinary "refers to the integration or synthesis of two or more disparate disciplines, bodies of knowledge, or modes of thinking to produce a meaning, explanation, or product that is more extensive and powerful than its constituent parts" (Rboten, O'Connor, \& Hackett, 2009, p. 86).

Kaiser-Meyer-Olkin (KMO) is a measurement for sampling each variable's adequacy overall (Cerny \& Kaiser, 1977; Dziuban \& Shirkey, 1974; Kaiser, 1970).

Kuomintang (KMT) is the ruling party in Taiwan. It was established by Sun Yat-sen and Song Jiaoren in mainland China in 1912. Later it governed the Republic of China starting from 1928, and in 1949, it moved to Taiwan (Kuomintang, 2015; Simkin, 2014).

Micro-Sized Enterprises (MSEs) refers to manufacturing enterprises with less than twenty employees and capital investments smaller than three-million yuan (the Chinese currency unit), wholesale enterprises with less than five employees and capital investments lower than tenmillion yuan, and retail enterprises with less than ten employees and capital investments lower than 4.99 million (Abe, Troilo, Juneja, \& Narain, 2012).

Mixed Methods refers to a research method that involves in both qualitative and quantitative methods. This type of combined method "recognizes the importance of traditional quantitative and qualitative research but also offers a powerful third paradigm choice that often will provide the most informative, complete, balanced, and useful research results" (Johnson, Onwuegbuzie, \& Turner, 2007, p. 129). 
Original Brand Manufacturers (OBMs) refers to brands that carry "the name of the original manufacturer (e.g., Johnson and Johnson, Hoover, Ford, Microsoft, Hewlett-Packard, and IBM)" (Doyle, 2011).

Original Design Manufacturers (ODMs) refers to companies that operate from designs. They develop and manufacture devices, items, or products under contracts, and their products are either rebranded by other firms or sold by other vendors or retailers (ODM (own design manufacturer), 2013; Original design manufacturer, 2015).

Original Equipment Manufacturers (OEMs) refers to companies that manufacture products or components of products for other brands, organizations, or individuals through contracts (Doyle, 2011).

The Pearl River Delta Economic Zone (PRDEZ) refers to one of the eight economic zones that is located in the Pearl River Delta area in the south part of China. It is dominated by two special administration regions-Hong Kong, Macao, and other cities like Guangzhou, Shenzhen, Zhuhai, Foshan, Zhongshan, Jiangmen, etc. (Zhang, 2011).

Private Enterprises (PEs) are businesses that are created and owned by private individualscitizens in a free-enterprise economic system (Law, 2009).

Project 211 refers to an educational project for one-hundred institutions of higher education in China. It intends to enhance crucial disciplinary areas through these institutions for national benefits in the twenty-first century (China Education Center Ltd., 2015; Zha, 2011). Project 985 refers to a constructive project conducted by the Chinese government with the purpose of developing world-class-level institutions in Chinese in the twenty-first century (China Education Center Ltd., 2015; Zha, 2011). 
Shanzhai (山寨) is a controversial term created by grassroots in China. On the one hand, it normally refers to products that are made by unpopular and small-sized manufacturers using low-cost techniques. These products are commonly labeled as a cheap copies or copycats $(\mathrm{Li}$, 2011). On the other hand, it is considered as a type of grassroots or open-sourcing innovation (Keane, 2013).

Small and Medium-Sized Enterprises (SMEs) refers to enterprises with specific amounts of employees and capital invenstments. Small-sezed enterprises are defined thusly: manufacturing enterprises with between twenty and 299 employees and capital investments between three and 19.99 million yuan, wholesale enterprises with between five and nineteen employees and capital investments between ten and 49.9 million yuan, and retail enterprises with ten to forty-nine employees and one to 4.99 million yuan in capital investments. Medium-sized enterprises require three-hundred to one-thousand employees and twenty to forty-million yuan in investments for manufacturing enterprises, twenty to two-hundred employees and fifty to four-hundred million yuan in investments for wholesale enterprises, and fifty to three-hundred employees and five to two-hundred million yuan in investments for retail enterprises (Abe et al., 2012).

State Owned Enterprises (SOEs) are organizations and enterprises that are fully or partly controlled by governments and not owned privately (Castree, Kitchin, \& Rogers, 2013). Township and Village Enterprises (TVEs) refers to "the different types of enterprises that are established in townships (including the villages under their jurisdiction) with the bulk of their capital being invested by rural economic collectives or farmers and that undertake the obligations to support agriculture," (Ding, Lan, \& Warner, 2001, p. 329).

Vocational Education and Training (VET) is "an alternative title for the further education sector" (Oxford University Press., 2015). Sectors may include continuing education and lifelong 
learning. In China, VET is divided into three levels, junior, senior, and tertiary (Ministry of Education of the People's Republic of China, 2006).

The Yangtze River Delta Economic Zone (YRDEZ) refers to an economic area that has many metropolises, such as Shanghai, Hangzhou, Suzhou, Wuxi, Nanjing, Ningbo, etc. (Zhang J., 2011). 


\subsection{Introduction}

Since the concept of creative industries was unveiled by the British Labour government in 1997 (Flew, 2012), followed by the idea of the creative economy introduced by John Howkins (2007), creative industries have been developed for many years in the United Kingdom (UK) and later implemented by many developed and developing countries. After many years of developing creative industries by demystifying epistemologies and definitions to make policies and develop architecture, the UK government realized that there was an urgent call for developing creative entrepreneurship education (DCMS, 2006). Not only can this type of new education match the demands of the market and creative graduates but also it can be a new direction in the development of entrepreneurship education (Carey \& Naudin, 2006; Penaluna \& Penaluna, 2006; Rae, 2012).

As the world's biggest developing country, China fosters the development of creative industries in order to transfer its older low-technological, high-polluting, labour-intensive manufacturing and economic model to a more sustainable, innovative, and technological based model (Keane, 2013; Li, 2011). However, creative entrepreneurship education as an integral part of the development of creative industries seems to be neglected in China. Neither business nor design schools in China provide creative entrepreneurship education. Although the development of entrepreneurship education in China has been burgeoning since the mid-1990s, programs in entrepreneurship education are mainly dominated by management studies, such as masters of business administration (MBA), and business plan competition (Li, Zhang, \& Matlay, 2003; Millman, Matlay, \& Liu, 2008). The fostering of students' creativity, positivity, and entrepreneurial intentions (EIs) towards new venture creation in entrepreneurship education in China are still missing, especially in education geared toward the development of creative 
industries. Additionally, mass enrollment and expansion in education are causing many problems that affect the development of design education in China. Young designers believe that what they learned from school programs is irrelevant to their professional environments and that is missing from their programs.

As a result, problems in the development of creative industries, design education, and entrepreneurship education in China are interrelated. Creative entrepreneurship education seems to be the most promising solution for tackling these problems. However, suggesting an approach for developing creative entrepreneurial education within design education in China requires enormous studies and vast research because there are too many uncertainties and concerns related to this suggestion. In the UK, motivations for developing creative entrepreneurship education in higher educational institutions (HEIs) at the national level are explicit. Developing creative industries for the UK is one of its national polices. This contributes to its economic development (DCMS, 2006). At the individual level, creative graduates and individuals have strong entrepreneurial aspirations and intentions. These two basic requests have been clarified, allowing policy makers, educators, scholars, and researchers to conduct further studies and implement experimental workshops, seminars, and courses for creative entrepreneurship education. However, in China, the approach for inserting creative entrepreneurship in design education is still just a theory. Based on this premise, this study uses qualitative and quantitative research methods to understand Chinese designers' EIs, investigate what entrepreneurial aspirations and motivations drive designers participating in creative entrepreneurship, and discover useful suggestions for introducing creative entrepreneurship to design education in China. 


\subsection{Background and Needs}

Since John Howkins invented the term creative economy in his book, The Creative Economy: How People Make Money from Ides, in 2001, many countries and areas, such as the European Union, the United Kingdom (UK), the United States (US), East Asia, Australia, and New Zealand, have embedded the idea of creative economy in their national strategic agendas as new models for their economic development (Flew, 2012; UNCTAD, 2008). In practice, these new models are developing creative industries. As an archetype, the UK not only used this model to bring its economy out of stagnation but also to preserve its economic sustainability and progression. After the development of creative industries succeeded in many developed economies, developing countries, such as Brazil, China, and some African countries, began establishing policies to develop their own creative industries (UNCTAD, 2008).

As one of the biggest developing countries in the world, China's conventional economic models were unsustainable for economic growth (i.e., low technological manufacturing, lowvalue exports, and a mass production infrastructure). Policies implemented by the Chinese government have triggered urbanization and industrialization in the eastern coastal regions for many years (Zhang, 2007). The three big economic regions, the Bohai Economic Rim (BER), centralized by Beijing, the Yangtze River Delta Economic Zone (YRDEZ), dominated by Shanghai, and the Pearl River Delta Economic Zone (PRDEZ), have consequently become the most developed regions in China (see Figure 1).

The developed-economic regions are yearning for a new, less-polluted, and sustainable economic model for maintaining their economic growth. In fact, all areas also need this model to sustain their economic growth instead of using older models. In this post-transitional economy, the model of developing creative industries is an alternative option (UNCTAD, 2008), because it 
can help China transform its transitional economy to a sustainable, innovative, and knowledgeable economy (Keane, 2013; Li W., 2011).

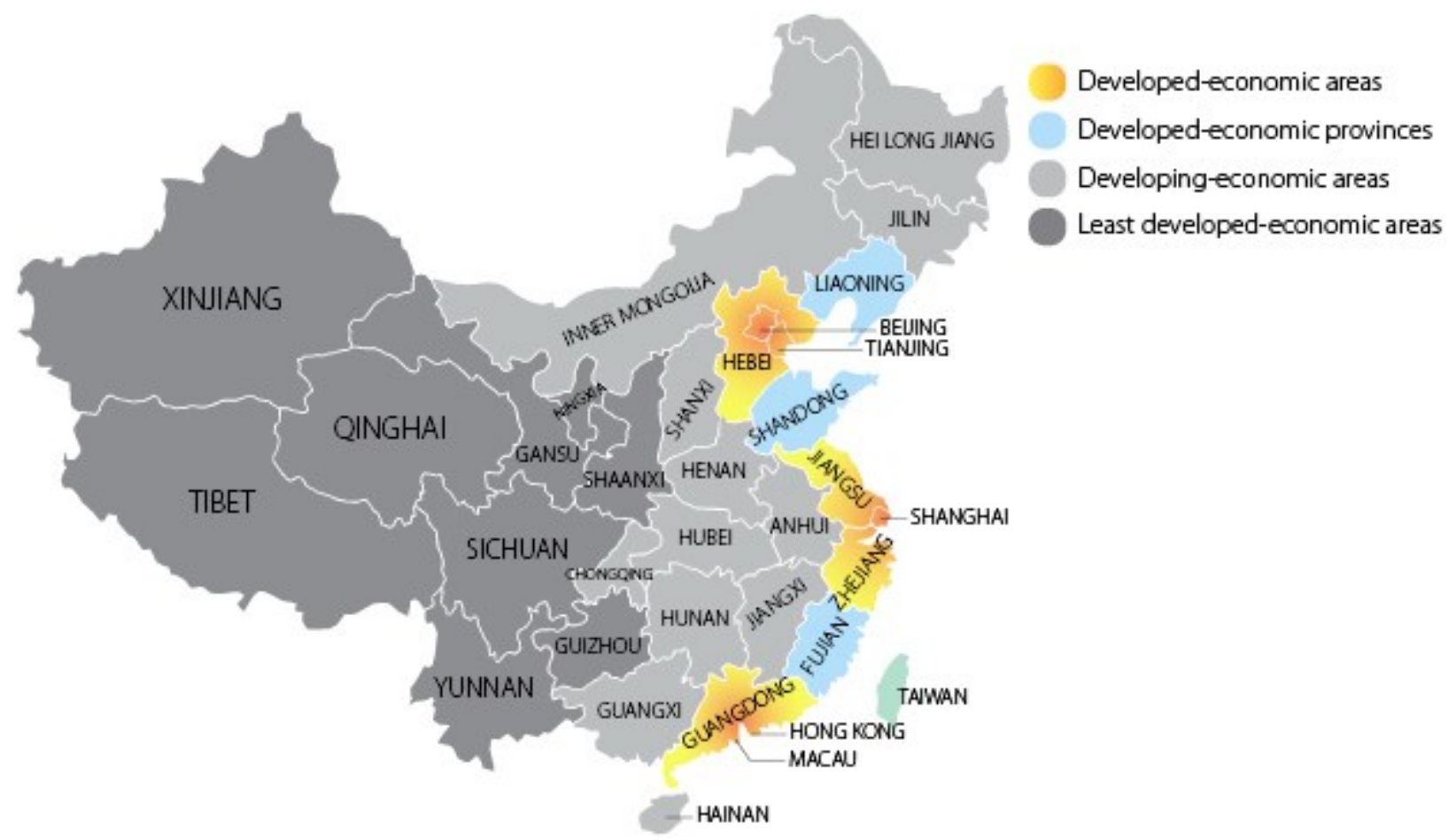

Figure 1. The three big economic regions (yellow) in China.

Internationally, educators have started to pay attention to entrepreneurship in the development of creative industries. For example, there are programs for studying creative industries from the bachelor level to the doctorate level at the Queensland University of Technology (QUT) in Australia, entrepreneurial learning in the context of creative industries in the UK (Rae, 2012), and the program of design practices in the School of Design at Hong Kong Polytechnic University (Ball \& Overhill, 2012; The Hong Kong Polytechnic University School of Design, 2014). However, design education in China is still far behind. 
In addition, Anderson (2012) argues that contemporary technologies, such as computer numerical control $(\mathrm{CNC})$ machines, 3D printers, online social media, online crowdfunding platforms, and mobility, allow creative individuals to make their own products and items. Ball and Overhill (2012) also suggest that it is feasible for Chinese designers to develop their own brands and make their own products. Options for self-employment and brand development in China now are inexpensive and easily available. Moreover, online crowdfunding platforms have suddenly attracted enormous attention in China (Bischoff, 2014; Xiang, 2015). This makes possibility of developing products, self-production, and creating micro brands much easier and more viable.

\subsection{Demystifying Problems}

Developing creative industries in China is not straightforward however. Challenges of developing creative industries are not only pertinent to the implementation of governmental policies but also to the maintenance of intellectual property protection. Although Keane (2013) and $\mathrm{Li}$ (2011) have suggested implementing governmental policies from the national level to the municipal level, increasing intellectual property (IP) regulations, intensifying the number of creative clusters, and transforming more cities to creative cities, one crucial aspect is not emphasized. This aspect is creative entrepreneurship education, which is significant for the development of creative industries (Carey \& Naudin, 2006; Carey \& Matlay, 2010; Penaluna \& Penaluna, 2006; Rae, 2012).

Moreover, problems in Chinese design education caused by mass enrollment and expansion in higher educational institutions (HEIs) are decaying and declining the quality of Chinese creative industries, especially in the long term. These issues will continue unless problems in design education are addressed. These problems include the lack of qualified 
teachers, outdated pedagogical methods, and inappropriate curriculums for design students. For instance, there are over 1,200 institutions in China providing design education (Hai \& Siu, 2011; Justice, 2012; Ling \& Zhang, 2012). Each school recruits around 290 students annually. This adds up to more than 340,000 students per year enrolling in design education. In the short term, these innumerable design graduates will access creative industries as creative workers. This raises many questions in terms of how many creative enterprises can recruit these young designers who have almost no working experience. How many of them will be employed by either design-related or non-design-related companies? Furthermore, many employers have complained that these young professional designers' skills and knowledge are too narrow and that they lack business knowledge and skills such as marketing and branding (Fung \& Lo Choi, 2001).

Entrepreneurship education in China still emphasizes conventional models_-business management, MBA, and business plan competitions. Entrepreneurial programs and curriculums are still dominated by business schools in China, although new directions have been launched, such as technological entrepreneurship (Millman, Li, Matlay, \& Wong, 2010) and entrepreneurship education for students outside business schools (Millman et al., 2008; Wu \& $\mathrm{Wu}, 2008)$.

In sum, problems in the development of creative industries, design education, and entrepreneurship education are interrelated. Creative entrepreneurship education seems to be an encouraging approach. Hypothetically, if such programs or curriculums existed in design education, not only would design students extend their knowledge and skills but also many of them would become nascent creative entrepreneurs because the EIs among design students could be enhanced through creative entrepreneurship education. 
In practice, administrators and policy makers could insert existing models from the UK into China's design education. However, due to cultural, social, and economic diversity between the West and China, this raises questions about how transplantable these models are. In addition, although drivers of entrepreneurship and entrepreneurship education between the UK and China have many similarities at the national level, such as developing entrepreneurship education for social sustainability and fulfilling demands from the changing economic environment (Galloway \& Brown, 2002; Jack \& Anderson, 1999; Li et al., 2003; Millman et al., 2008; Millman et al., 2010; Nabi \& Holden, 2008; Rae, 2005; Wu \& Wu, 2008), entrepreneurial aspirations and intentions at the individual level may be different. Particularly, the EIs among Chinese designers are still unclear. Without knowing designers' entrepreneurial aspirations, motivations, and drivers, the suggestion of introducing creative entrepreneurship education into China's design education becomes difficult. Thus, before proposing the approach of introducing creative entrepreneurship education into design education in China, studies about entrepreneurial aspirations, motivations, and drivers would be highly beneficial.

\subsection{Purposes of the Study}

The aim of this study is to investigate what Chinese designers' entrepreneurial aspirations, motivations, and drivers are and how these might affect creative entrepreneurship in China's design education. Theoretically, the approach of introducing creative entrepreneurship into design education in China could alleviate issues caused by mass enrollment and expansion in China's design education by stimulating potential creative entrepreneurs. The approach would be a new orientation - an interdisciplinary program for the development of design education and entrepreneurship education in China. It would provide vast opportunities to designers who intend to create their own business and brands. 


\subsection{Research Questions}

As a prerequisite to this hypothetical approach, research questions were developed that address entrepreneurial aspirations, motivations, and drivers of Chinese designers. Because the hypothetical approach is interrelated to three diverse categories, the development of creative industries, design education, and entrepreneurship education in China, the research questions are as follows:

1. What are the entrepreneurial drivers that would stimulate the development of selfemployment and entrepreneurship among designers in China?

2. Who would be potential creative entrepreneurs in China?

3. What aspects should be taken into consideration when designing creative entrepreneurship education for designers in China?

\subsection{The Scope of the Study}

Firstly, the essential contribution of this study is to raise awareness about the importance of creative entrepreneurship education among China's policy makers, educators, scholars, and researchers. The infrastructures for the development of creative industries in some eastern coastal areas in China have been well developed ( $\mathrm{Li}, 2011)$. Many current studies and research about the development of creative industries in China are focusing on strategic implementation, policy making, and infrastructure development. Studies pertinent to design education or entrepreneurship education in China are easier to find, but sources and data related to creative and design entrepreneurship education in China are very rare. This study could be the starting point. Secondly, as a big and novel topic, which has its complexity related to three areas (i.e., the development of creative industries, design education, and design entrepreneurship), this study provides much needed data for this topic. 
This study also suggests a solution for generating potential nascent creative entrepreneurs through education. These nascent creative entrepreneurs could contribute to the development of creative industries in China. In fact, enlargement of creative enterprises requires creative individuals to become creative entrepreneurs. This study suggests a new orientation for the development of China's design education. Moreover, academics, scholars, and researchers may also be inspired by this study. They may conduct further research on how design and design education can contribute to the development and improvement of the creative economy, creative industries, and entrepreneurship education in China.

\subsection{Delimitations}

This research will be the first known study related to the topic of creative entrepreneurship education in China. Many current studies about China's design education are about pedagogical methods, design epistemology, design cultures, and design practices.

Databases regarding design and designers in the professional environment are undeveloped.

Despite the complexity of this study, it is unable to encompass all aspects of creative entrepreneurship education per se. Thus, a number of delimitations need to be addressed. Firstly, this study does not compare existing models and programs of creative entrepreneurial programs, such as studies about the development of creative entrepreneurship education that are continuing in the UK. Without existing creative entrepreneurial programs in China, it is impossible to discover the differences between programs in different countries and areas.

Subsequently, this study in itself does not constitute a proposal for introducing creative entrepreneurship into design education in China; that would require much future research. Such a proposal requires enormous efforts beyond the scope of this study. Moreover, this research does not investigate what cause certain design entrepreneurs to be successful, or what their business 
models might be. Finally, there is no psychological perspective in terms of investigating similarities and dissimilarities between designers and design entrepreneurs. In addition, the focus of this research does not pertain to studies of comparison between micro-business development and entrepreneurial psychology. 


\subsection{Literature Review}

This section articulates the background and current milieu of design in China. Problems caused by mass enrollment, expansion in design education, the development of creative industries, as well as issues of entrepreneurship education in China, are identified as rationales

for the research. Firstly, the definition of design needs to be framed in the context of this study.

2.0.1 Defining design. According to De Mozota's (2003) synopsis, environmental design, product design, package design, and graphic design are the four general categories of design disciplines. Commonly, industrial design and product design in the context of the design community are interchangeable, even though their definitions are slightly diverse. Thus, in this paper, industrial design and product design are exchangeable. In terms of dimensional categorization in design disciplines, $2 D$ design includes graphic design, information design, illustration, and textile design, while $3 D$ design includes furniture design, fashion design, interior design, industrial design, and environmental design, and 4D design includes digital design, interactive design, and web design (De Mozota, 2003). In fact, each design discipline has a long history. It is arduous to illustrate all design disciplines precisely, therefore, the contexts of design in this research will mainly relate to industrial design, but other design disciplines are still included.

\subsection{Design in China}

In this thesis, design in China only refers to design in the mainland of the People's Republic of China (PRC). In the reality, China's design should include design in mainland China, Hong Kong (HK), Macau, and Taiwan. However, for historical and political reasons, contents of design in HK, Macau, and Taiwan are excluded in this study. For instance, as Wong (2011) describes, the development of contemporary design in both HK and Taiwan occurred 
faster and earlier than in mainland China. On the one hand, Taiwan's design progression has been strongly influenced and dominated by Japanese design because Taiwan had been colonized by Japan for a half century. On the other hand, design in HK has been benefited by the British due to colonial aspects, especially in its design education (Wong, 2011). Due to a geographic reason and its population, Macau's design is usually included as a part of HK's design.

2.1.1 A brief history of China's design. The beginning of modern design, advertising, and graphic design in China, started in Shanghai during the period of the Republic of China (RC), governed by the Kuomintang (KMT), from the late 1920s to the mid-1930s (Sinha, 2008; Wang, 1989; Wong, 2001; Zhang \& Parker, 2008). However, the development of design in China started to change after the establishment of the PRC (Justice, 2012; Sinha, 2008; Wang, 1989; Zhang \& Parker, 2008).

From 1949 to 1979. Due to political reasons, China's socioeconomic milieu experienced dramatic fluctuations. Design, graphic design, and advertising, existed as political tools — making political propaganda products (Justice, 2012; Wang, 1989; Wong, 2001; Wong, 2005). Designers at that time were artist-workers or decorators. When Gaige Kaifang was implemented, the economic reforms began at the end of 1978, and China entered into a transitional economy. The development of Chinese design started its growth and to development as a systematic design pedagogy (Wong, 2005).

From 1979 to 1999. Privatization happened among enormous state owned enterprises (SOEs), and micro-sized and small-sized private enterprises began emerging in the Pearl River Delta (PRD) area. Advertising and graphic design developed rapidly, particularly in the PRD area and Shanghai (Wang, 1989; Zhang \& Parker, 2008). In the meantime, the concept of commercial design began being perceived by design educators and designers because of the 
influence of Europe's, Japan's, Taiwan's, and HK's designs (Justice, 2012; Wong, 2001; Wong, 2005; Zhang \& Parker, 2008). Imitation was gradually being populated in not only advertising and graphic design but also product design (Wang, 1989). The growth of design education started across the country. Design departments and schools in institutions gained the autonomous right of developing their disciplines, curriculums, and programs (Wong, 2005).

From 1999 to present. From 2003 to 2013, the average rate of the gross domestic product (GDP) in China sustained 10.3\% growth (Aridas \& Pasquali, 2013). This economic success has been burgeoning urbanization and industrialization of many urban areas in China (Zhang, T., 2007). Existing products and services made by companies no longer satisfied the needs of customers. Middle class demands triggered companies to produce high-quality products with good designs (Justice, 2012; Sinha, 2008; Yu, Chan, \& Ireland, 2007; Zhang \& Parker, 2008). The demands from the market required more talented designers.

Design education entered a blooming era. Most of the current design schools, design departments, and design programs in China were established between 1999 and 2010. By 2007, the number of design schools and design programs were over fifty times bigger than the numbers in the 1980s (Muynck \& Carriço, 2012). For example, around 1,700 art and design students graduated across the country in 1989 (Wong, 2005), but around 250,000 design students graduated in 2003 (Hai \& Siu, 2011). Design weeks, exhibitions, conferences, and competitions are prevalent. This includes the China Red Star Design Award in Beijing, the Successful Design Award in Shanghai, and the Kapok Design Award in Guangzhou (Muynck \& Carriço, 2012). However, the hasty development in design education in China also caused many problems.

2.1.2 Endemic problems in China's design education. Endemic problems in design education are mainly caused by the expansion and massification of HEIs in China. According to 
Zha's (2011) study, the expansion and massification in HEIs are generated by political and economic reasons that are supporting the country's social and economic development and prosperity. After The Outline of Educational Reform and Development in China (OERDC) was implemented by the State Council of China (SCC) in 1993, expanding and reforming higher institutions became the priority of developing higher education in China. HEIs based on a stratified and hierarchical system are split into three levels that are based on administration and funding support: the national level (tier one schools), at the top; the regular level at regular public universities, in the middle (tier two schools); and the level of vocational colleges and private universities and colleges, at the bottom (tier three schools).

At the national level, around one hundred universities were merged and reformed from traditionally prominent universities to become higher standing institutions at the national levelinstitutions in Project 211 — and competitive institutions with global recognition - institutions in Project 985. Institutions in Project 211 and Project 985 are continuously run by the ministry of education (MOE) and other ministries. However, other formerly ministry-run universities and independent colleges are run by provincial administrations. These universities and independent colleges are considered to be regular level public institutions. At the bottom, the level of vocational colleges and private universities and colleges are authorized by either provincial governments or provincial ministries of education. Many of these institutions do not have a high reputations and are located in second and third-tiered cities.

In fact, regular public universities and independent colleges contribute most of the enrollment (Zha, 2011), and institutions in the private sector contribute a great number of enrollment as well (Chen D. Y., 2004). Firstly, by recruiting more students, these institutions can acquire more finances (Bai, 2006; Zha, 2011). Without direct funding from the MOE or other 
ministries, enormous institutions in developing and less developed regions either need financial support from their local governments, or they need to acquire funding via student's tuition fees. Thus, institutions started charging students' tuition fees in 1997 as a result of official policies. Consequently, students' enrollment and the expansion of institutions started to soar (Zha, 2011). Secondly, demands for more educated employees also stimulated HEIs to expand new departments and disciplines and to increase their recruitment. Additionally, the more new departments and disciplines that were established, the more students these institutions could recruit. The more students these institutions could recruit, the more finances they would obtain. The third reason was that, in 1998, a couple economists advised that enrollment expansion would increase educational consumption and economic benefits (Chen D. Y., 2004; Zha, 2011).

Chinese design education cannot avoid the effects caused by mass enrollment, expansion, and massification in HEIs. The mass enrollment in design education was caused by a couple of reasons. The first reason was social demands. The booming development of original equipment manufacturers (OEMs) and original design manufacturers (ODMs) created demand for design graduates. Tremendous amounts of non-design institutions discerned the demand of design from the labour market, and they started to establish design departments and programs. Secondly, HEIs can benefit from design students' tuition fees. Students who study design normally have to pay more tuition than students who study non-design subjects. Thirdly, high school students who apply for design schools, design programs, or programs related to art and design more easily access universities and colleges compared to students who apply for other majors. This is because the Gaokao score requirements for majors pertaining to art and design are lower than the requirements for other majors based on the national matriculation examination (NME). The fourth reason is that, at the beginning of the expansion of design education, design graduates' 
wages and employment rates were higher than those of graduates who studied other disciplines. Thus, enormous amounts of high schools students applied for design programs and selected design as their future major. Finally, all these rationales triggered design schools, departments, and programs to become defaults in China. Even agricultural universities, normal universities, and universities of geoscience, finance, and economics are all established design programs and curriculums (Ling \& Zhang, 2012).

This mass enrollment directly resulted in some severe issues in China's design education. At the horizontal level, the disparities of resources and finances as well as developments in design education are caused by mass enrollment. Top design schools that have a long historical development not only acquire abundant resources and financial support from the MOE and provincial governments but also recruit professional lectors and talented students. These schools include the Academy of Arts and Design at Tsinghua University (Tsinghua University, 2010), the School of Design at Jiangnan University (Jiangnan University, 2013), the School of Design at Hunan University (Hunan University, 2008), the School of Design at the China Academy of Fine Arts (CAFA, 2015), etc. Most of them are at the national level. These schools are in developedeconomic regions and coastal cities. For other newly established design schools, most of which are at regular public universities or at the level of vocational colleges or private universities and colleges, they cannot gain enough financial support and recruit qualified teachers. Top design schools in China hastily developed partnerships with foreign top design schools and created collaborative programs and workshops to reduce the gap between leading design schools in the West and themselves in design pedagogy, education, and research. However, the majority of design institutions in China are still behind the global propensity in design pedagogy. 
At the vertical level, the evolution of design pedagogy in China's design education is stagnated. Because the development of design education has deep roots in traditional fine art and aesthetic craft (Wong, 2005), design programs and curriculum are dominated by art-oriented schools such as China Academic of Fine Arts, the Guangzhou Academy of Fine Arts, the Xi'an Academy of Fine Arts, etc. Moreover, there are two orientations for industrial design in design schools in China. One is aesthetic and art-oriented, and the other is engineering and mechanically-oriented. Mechanically-oriented industrial design programs are offered by some technological and scientific institutions, such as the Beijing Institute of Technology, the Beijing University of Technology, and the Harbin Institute of Technology (Ling \& Zhang, 2012). Although art-oriented and mechanically-oriented design programs are gradually emerging, the teaching methodologies in the discipline of industrial design in design schools in China are still majorly dominated by the art-oriented style.

According to Ling and Zhang's (2012) study, students in aesthetic and art-oriented dominated schools lack appropriate knowledge of mechanics and engineering. Students in mechanically-dominated schools are the opposite. Aesthetic and art-oriented design schools are still using the Bauhaus' methodologies in their design pedagogies, but merely emphasizing artistic skill training instead of using interdisciplinary and contemporary design methods, such as teaching design, thinking, and problem solving to students, is problematic.

In Fung and Lo Choi's (2001) study, they discovered that "Chinese design teachers did not always have a clear idea about how the new innovative design curricula and accompanying teaching and learning methodologies could be implemented in practice" (p. 175), albeit these teachers have had knowledge about design education practices in the West and in HK. Many young teachers have limited experience in design practices and teaching. Moreover, because of 
the burgeoning expansion in design institutions, new design schools are unable to recruit professional design teachers who not only have teaching experience but also working experience. A number of new design schools directly hire young graduates from other institutions as their design teachers. Obsolete curricula are still being used in both long-established and renowned design schools (Muynck \& Carriço, 2012). Students cannot be educated professionally by teachers who do not have enough practical experience. As a result, Chinese design graduates do not always have the skills that the market wants them to have, and employers complain that these students were not trained in the right ways (Muynck \& Carriço, 2012).

2.1.3 China's design milieu. Although opportunities for young Chinese designers are rich, competition among young design graduates is still brutal. According to Ling and Zhang's (2012) study, there are four types of platforms for design and innovation in China. First, design and innovation are based on the manufacturers' platforms. This means design and innovation are needed by original equipment manufacturers (OEMs), original design manufacturers (ODMs), and original brand manufacturers (OBMs). The second type of platform is design-consulting firms. The third type of platform is design associations supported by governments, and the fourth type of platform is design ateliers organized by design institutions. Design associations and institutional design ateliers that can facilitate state owned enterprises (SOEs) and private enterprises (PEs) are engaging with design institutions. This experimental cooperation can intensify SOEs and PEs' innovation and improve design institutions' methodological developments as well.

All design jobs are virtually covered by these four types of platforms in China. Multinational conglomerates and famous design consulting firms magnetize proficient young design graduates from leading design schools across the country. The raising discernment of 
design and innovation has generated innumerable domestic OBMs and SOEs starting to recruit talented design graduates from top design schools as well. In addition, China now not only captivates global capital but also global human capital. Smart, intellectual, and competitive designers and design graduates from Europe, America, Japan, Korea, Singapore, Taiwan, and HK are moving to China for success (Lin, 2011; Toloken, 2010). Many of them have interdisciplinary knowledge (Vanchan \& Bryson, 2013). Moreover, Chinese design graduates from foreign leading design schools have started to return to China for better opportunities, instead of staying in the countries where they graduated (Justice, 2012).

As a result, Chinese design graduates from domestic and foreign top design schools and foreign design graduates are all competing for design jobs that are provided by multinational conglomerates, domestic OBMs, and design firms in China. This means that design graduates from renowned design schools and private universities and colleges (most of these schools are at the regular level and the level of vocational colleges) have to compete with graduates from leading design schools (most of these schools are at the national level). Graduates from design schools at the regular level or from private institutions will have difficulties applying for good positions. The aftermath of the global financial crisis in 2008 plus increasing labour and material costs compel enormous amounts of small-sized OEMs to shut down. Furthermore, many middlesized ODMs and some OBMs are moving from the PRD and YRD areas to hinterland provinces such as Sichuan, Guizhou, Henan, etc. (Xinhua, 2012). Thus, the rivalry of job applications for young design graduates who want to work for OEMs, ODMs, and OBMs and stay in cities located in the PRD and YRD areas becomes severe.

Young Chinese designers do not only need to deal with job competition but also cope with inadequate knowledge in their field. In Xiao and Wu's (2011) study, they interviewed sixty 
graduates. Only $26(43.3 \%)$ were working as designers or working in industries that relate to design. Close to $52 \%$ did not work as designers, and three people were unemployed. In another study, Chen (2008) interviewed a number of interior designers and architects from Beijing and Hangzhou. Despite the fact that junior designers' wages are still higher than other occupations on average, designers' average working hours were found to be as high as twelve to fifteen hours per day. Some of them constantly need to work more than thirty-two hours per week.

Furthermore, Zhou's (2008) study demonstrates that $45 \%$ of designers believe that they need to upgrade their skills and knowledge. Fifteen percent consider applying for a postgraduate or vocational program. Half of them were found to be satisfied with their wages, but the other half were not. Although these studies only can represent design graduates' occupational situations on a small scale, these studies still portray that graduates from renowned design schools and regular public institutions may have difficulties gaining and performing their positions after graduation. This also illustrates that design graduates from vocational colleges and private universities and colleges may be coping with poor situations in terms of job security.

\subsection{Creative Industries in China}

The concept of creative industries was introduced to China through the Shanghai Creative Industries Development Forum in 2004 (Keane, 2009; Keane, 2013; Li, W., 2011). Li suggests that creative industries have four values in China:

- Transformation of resources: Creative industries turn various natural and cultural, tangible and intangible resources into capital for economic development. At the same time, they promote the transformation of various kinds of capital (economic, cultural and social). 
- Value upgrade: R\&D, design, sales, branding and services are the key links to increasing industry value added and to bringing about a transformation from 'made in China' to 'created in China.'

- Structural optimization: Creative industries optimize the structure of traditional cultural industries by re-creating and re-upgrading the resources of these industries. In addition, creative industries optimize the structure of primary, secondary and tertiary industries.

- Market expansion: The cultural features contained in a product can help the product to increase its value, and therefore sales, and to target a more diverse range of consumer demographics. (Li, W., 2011, pp. 3-4)

From a socioeconomic perspective, the conventional economic models are unsustainable for economic growth in China. From a sociocultural perspective, young generations in China have started to embrace Western culture instead of traditional Chinese culture, such as Beijing Opera, comedy crosstalk, and Confucianism (Keane, 2013; Li, 2011; Yu et al., 2007). Moreover, more and more educated middle class individuals are craving high-quality, well-designed, and innovative products and services in different industries. This demand has become a catalyst for burgeoning the development and diffusion of creative industries in China.

Although the appearance and the socioeconomic value of creative industries have been increasing since 2006, the conversion from the current model of 'Made in China' to a model of 'Created in China' is still in the earlier stage. Firstly, the Chinese bureaucratic system may slow the efficiency of implementing creative industries from province to province. Secondly, although intellectual property (IP) legislation has been implemented by the Chinese judicial system, the 
piracy problem known as Shanzhai is continually harming the intellectual capital in the development of creative industries in China (Li, 2011).

Thirdly, the development of creative industries in China lacks human capital. In terms of human capital, Howkins (2007) refers to education and training. He also suggests that "creative people," the "job of thinker," the "creative entrepreneur," and the "just-in-time person" are the key players in creative industries (Howkins, 2007). Establishing a creative class is the keystone of developing creative communities and creative cities (Flew, 2012; Florida, 2002; Li, 2011; Scott, 2010). However, the education system in China does not offer any creative entrepreneurial programs for management or entrepreneurship. Most of the managerial and entrepreneurial programs are provided by business schools, but none of these programs pertains to creative entrepreneurship or creative entrepreneurship management for creative industries (Li et al., 2003; Millman et al., 2008).

The lack of competitiveness in the Chinese creative class also affects the development of creative industries in China. For instance, the research of Chu, Gao, and Ma (2007) demonstrates that $34 \%$ of Chinese creative enterprises are from the Bridge 8 Creative Industrial Park, Luwan District, Shanghai. In contrast, $66 \%$ are from HK, Taiwan, and other countries. This scarcity of competency is the result of many factors. However, the competency of human capital, education, and training are the prime reason. In fact, the educational system in China is concentrating on quantity instead of quality. Under this circumstance, Chinese graduates cannot compete with their counterparts from other countries.

\subsection{Entrepreneurship and Entrepreneurship Education}

The French economist, Richard Cantillon, invented the term entrepreneur in his 1732 treatise, and its English translation was published anonymously in 1755 (Matlay, 2005). Since 
that time, in the academic world, the terms entrepreneur, entrepreneurial, entrepreneurship, and enterprise and studies related these terms have been evolving for many decades. However, both arguable and achievable issues of entrepreneurship are how to define it and what its socioeconomic values are.

In a report by Global Entrepreneurship Monitor (GEM) in 2009, entrepreneurship is defined by three primary features: attitudes, activity, and aspirations (Bosma, Levie, Bygrave, Justo, Lepouter, \& Terjesen, 2010). The report explains that entrepreneurial attitudes "are attitudes toward entrepreneurship. For example, the extent to which people think there are good opportunities for starting a business, or the degree to which they attach high status to entrepreneurs, might be termed entrepreneurial attitudes" (p.10). Moreover, "other relevant attitudes might include the level of risk that individuals might be willing to bear and individuals' perception of their own skills, knowledge, and experience in business creation" (p. 10). Entrepreneurial activity is pertinent to a process of creating a new business and any comparable economic activities. Entrepreneurial aspiration is related to "the qualitative nature of entrepreneurial activity" (p. 11), such as inventing new products and services, entering new markets, etc. In fact, entrepreneurship's contributions to societies and economies, such as wealth creation, employment generation, and production innovation, are undeniable (Acs, Desai, \& Hessels, 2008; Jack \& Anderson, 1999; Low \& MacMillan, 1988; Bosma, et al., 2010).

Recently, studies of entrepreneurship have emphasized how to embolden individuals to become nascent entrepreneurs and how to develop the skills necessary for securing their start-ups (Matlay, 2005; Matlay, 2006). Whether nascent entrepreneurs are born or made is an ongoing debate. The fact is that rationales of being an entrepreneur are diverse (Carter, Gartner, \& Reynolds, 1996; Gibb \& Ritchie, 1982), but entrepreneurial skills and knowledge can only be 
acquired from pragmatic working experiences or academic education (Hynes, 1996; Gibb, 2002; Matlay, 2006; Rae, 2005).

In fact, epistemological approaches to entrepreneurship education have been enhanced diversely for many years. Particularly in the West, entrepreneurial programs have been suggested to dispersing out from business schools (Hynes, 1996; Gibb, 2002; Matlay, 2006). Traditional entrepreneurial topic courses, such as business planning, managerial strategies, theoretical knowledge, and cases studies, have become sub-topic courses in new entrepreneurial educational approaches (Matlay, 2006). New approaches are not focusing on learning about entrepreneurial knowledge and skills; instead, they are emphasizing doing entrepreneurial activities. In other words, letting students create a genuine microenterprise through entrepreneurial programs instead of learning contextual knowledge is the new tendency.

Because of the uniqueness of entrepreneurship, traditional entrepreneurship education does not allow students to transfer their conceptual knowledge into real practice. New approaches to entrepreneurship education suggest learning by doing (Gibb, 1997; Gibb, 2002; Rae, 2005; Vincett \& Farlow, 2008). Students should develop a genuine business and learn from the process of building it. Thus, the process of building a small business includes planning, managing, negotiating, and connecting all sources, customers, and stakeholders together. This type of learning needs to deal with everyday uncertainty, and it is arduous to gain experience from conventional entrepreneurial courses. Hence, a combination of experimental and contextual learning in entrepreneurship education is necessary. Other new approaches to entrepreneurship education are even going further. For instance, Gill (2002) suggests that entrepreneurship education should be not only a matter of conventional business schools to educate students but also an integral part of the pedagogy for academia and society as a whole. 
Based on Gill's (2002) philosophical approach of a new direction for the epistemology for entrepreneurship education, educating people to have entrepreneurial knowledge and skills or entrepreneurial mentalities is not only the duty of a conventional business schools but also the responsibility of education in general. From this perspective, entrepreneurship education should not be restricted to only the conventional discipline—-business. Entrepreneurship education should be introduced into other disciplines, such as biotechnology (Gibb, 2002), computer science (Matlay, 2006), engineering (Hynes, 1996), design (Carey \& Matlay, 2010; Gunes, 2012; Rae, 2012; Teixeria, 2010), etc.

\subsection{Entrepreneurship Education in China}

Synopsized from previous studies of entrepreneurship education in China (Li et al., 2003; Millman et al., 2008; Millman et al., 2010; Mu, 2006), the development of entrepreneurship education in China is caused by a number of rationales. Firstly, entrepreneurship education will contribute to the development of small and middle-sized enterprises (SMEs) and private enterprises (PEs). This is because the momentum of SMEs and PEs in the last two decades have not only provided innumerable job opportunities but also contributed to the economic prosperity of Chinese society. Secondly, the success of the model of entrepreneurship education in the West became an archetype for Chinese entrepreneurship education. Thirdly, the development of hightech giants, such as Sina, Tencent, Alibaba, and Baidu, became successful examples with which to encourage entrepreneurship education being burgeoned in HEIs. Fourthly, entrepreneurship education can produce more and more nascent entrepreneurs to develop SMEs on the one hand, and it can release the pressure caused by high unemployment rates on the other hand.

By the late 1990s and the early 2000s, entrepreneurship education in China entered a new era. The model of business competition in entrepreneurship education was started among some 
HEIs. In 1998, Tsinghua University was the first institution to hold the Student Business Plan Competition (SBPC). The following year, the Challenge Champion Business Plan Competition (CCBPC) superseded the SBPC and became the definitive business plan competition for high institutions (Li, et al., 2003; Millman et al., 2008). These types of competitions offered a new platform for fostering students' developing skills and knowledge for innovation, creativity, and entrepreneurial management. Meanwhile, these successful contests attracted attention and gained funding for further development. The MOE also decided to extend entrepreneurship education from the postgraduate level to undergraduate level. Later, two other programs were launched by the MOE, the Pilot Entrepreneurship Education Programme (PEEP) and the Know About your Business (KAB) program. The purposes of these new programs include increasing entrepreneurship awareness, entrepreneurial skills, and knowledge acquisition and integrating entrepreneurship training (Millman et al., 2008). Within these programs, students simultaneously learn entrepreneurial skills, gain knowledge, and used their capacities to participate in business plan competitions. Winners use the award money to fund their start-ups. This encourages more students to engage with entrepreneurship education as well. Finally, technological entrepreneurship became a new approach to entrepreneurship education (Li et al., 2003). It is also known as internet entrepreneurship (Millman et al., 2010). This approach is a result of the booming internet users and the e-commerce in China.

As students' EIs become explicit, their attitudes support the development of entrepreneurship education. For example, Wu and $\mathrm{Wu}$ (2008) conducted a study at Tongji University in Shanghai. They discovered that EIs among students are positive. Students with diplomas and undergraduate degrees are more interesting in terms of entrepreneurship than students with postgraduate degrees are. Academic majors affect and influence EIs. Engineering 
students have the highest EIs. However, their study also shows that entrepreneurial curricula do not have significant impacts on respondents' entrepreneurial ideas.

Another example is Mu's (2006) study of 511 students. It found that $83 \%$ of participants considered entrepreneurship education a prerequisite to higher education in China. Additionally, $77.8 \%$ of the students believed that entrepreneurial programs could improve their knowledge, skills, and capacities form unilateral levels to multilateral levels. It was also found that $62.5 \%$ of participants believed that they could obtain some pre-working experience and extend their social network through entrepreneurship education. Moreover, $37.5 \%$ of the participants expected that they could acquire creative and innovative capacities through entrepreneurship education, and $31.5 \%$ of participants anticipated that institutions could establish entrepreneurial management programs or programs for business creation. Conversely, Mu (2006) also points out that students complain they cannot learn useful entrepreneurial knowledge and skills from current entrepreneurial programs. Students believe that current curricula and courses are unprofessional, and their EIs do not increase as a result of these unprofessional programs. However, although entrepreneurship education in China has seen a rapid development at various levels, there is still a missing category — creative entrepreneurship education-which can directly improve the development of creative industries.

\subsection{Creative Entrepreneurship or Design Entrepreneurship}

The terms, creative entrepreneurship and design entrepreneurship, are easily confused. They are literally different but have similarities at some points. Based on the interpretation from the United Nations Conference on Trade and Development (UNCTAD) (2008), creative entrepreneurship means entrepreneurship in creative industries. In other words, creative entrepreneurs are those that develop or operate their ventures in creative industries, for example, 
a musician, an artist, or a freelance graphic designer who works for himself or herself, or a film developer, a 3D designer, or a craftsman who creates his or her own firm. However, creative entrepreneurship also means creativity in entrepreneurship. This means that creative entrepreneurs include not only artists, musicians, designers, and so on but also other creative people.

Conversely, Gunes (2012) articulates that design entrepreneurship means "the collection of correct skills and abilities to develop the right ideas and market them as the successful design products" (p. 65). He also defines the skills necessary for entrepreneurs as executive, business planning, managerial, and creative issues skills. Design entrepreneurship in Gunes' context is under the circumstance of product design.

In accordance with the aforementioned explanations, creative entrepreneurship and design entrepreneurship have their similarities. Moreover, design, as one category, is included in creative industries (Flew, 2012; Howkins, 2007; Keane, 2013; Li, 2011; UNCTAD, 2008). Designers are one type of the creative class, creative participants, or creative contributors. From this perspective, design entrepreneurship, by its definition, is not as broad as the meaning of creative entrepreneurship. Because the term design in this study is not only limited to product design, the researcher prefers to use the term creative entrepreneurship instead of design entrepreneurship. Another reason for this is the fact that the term creative entrepreneurship is more prevalent in China.

\subsection{Blending Entrepreneurship and Design in Education}

Because evolving the creative economy is one of the prime policies on the agenda for economic growth in many countries, sustaining the capacity of perpetual development in these countries' creative industries is required. Education becomes the only engine that can support 
powers for the development of creative industries. Meanwhile, due to the structure and size of creative industries, the majority of creative industries are comprised of self-employed people, freelancers, micro-sized enterprises (MEs), and small and medium-sized enterprises (SMEs) (Flew, 2012; Florida, 2002; Howkins, 2007; UNCTAD, 2008). Improving the development of creative industries means improving the development of MSEs and SSEs. Based on this perspective, introducing entrepreneurship education to promote the development of creative industries is reasonable (Carey \& Naudin, 2006; Carey \& Matlay, 2010). This approach also provides a new direction for the conventional development of entrepreneurship education (Penaluna \& Penaluna, 2006; Rae, 2012). In fact, inserting entrepreneurship into design education could be a controversial approach for both business and design academia. It could be argued that either design should be inserted into entrepreneurship education to develop creative entrepreneurship education or entrepreneurship could be inserted into design education to develop entrepreneurial design education. However, Penalunas' (2006) study argues that many creative individuals and students do not think traditional business studies meet their needs or that the methods of teaching in regular business schools does not attract creative students. Penalunas (2006) suggest “a model that embeds 'entrepreneurship', as a 'core' module within the art and design discipline" (p. 2).

On the one hand, capacities for creativity and innovation are integral parts of success in future business development (Verganti, 2009). Educators also recognize the essentiality of creativity for entrepreneurship education (Kirby, 2004). On the other hand, Ball's (2002) study points out that design education needs to involve entrepreneurial and business education due to a lack of business awareness and knowledge, project management skills, and career management skills, such as networking, research skills, and the ability to gathering information, among 
creative graduates. Furthermore, from the perspective of design and entrepreneurship education, it seems that it is rarely mentioned that creative individuals, such as musicians, designers, and artisans, have desires to be entrepreneurs or involved entrepreneurship. However, Carey and Naudin (2006) argue that creative individuals do have entrepreneurial tendencies. In fact, in the report from the UK's the Department for Culture, Media and Sport (DCMS), Developing Entrepreneurship for the Creative Industries: Making the Case for Public Investment, found that graduates in creative disciplines are more likely to become self-employed, and they feel that their degrees have not adequately prepared them for careers in creative industries (DCMS, 2006). Gunes (2012) also suggest that "entrepreneurship based design education is a crucial foundation for creativity and innovation driven economic development" (p. 66). Entrepreneurship education can help "design students to embrace managerial, economic and strategic thinking knowledge, as well as design skills and motivation to encourage entrepreneurial success" (Gunes, 2012, p. 66).

From these scholars' perspectives, entrepreneurship, creativity, and design need to be blended together. The following are needed: A) entrepreneurial emphasis with creative and design support; B) creative and design emphasis with entrepreneurial support; and C) entrepreneurial, creative, and design equality. The next section will present two case studies to illustrate creative entrepreneurship education in practice.

\subsection{Two Case Studies}

In order to help explain creative entrepreneurship education, two case studies are presented. The Student Placement for Entrepreneurs in Education (SPEED) in the UK represents entrepreneurial, creative, and design equality. Another case is a practical design course, Design Direct: How to Start Your Own Micro Brand, offered by the School of Design at the Hong Kong Polytechnic University (HKPU). It represents design emphasis with entrepreneurial support. 
2.7.1 Student placement for entrepreneurs in education (SPEED) in the UK. In his article, "Action Learning in New Creative Ventures," Rae (2012) describes the following: The SPEED project set out to enable university students to establish their own business ventures as work experience projects, and created a significant, innovative example of action learning applied to new venture formation and entrepreneurial development. It was funded by the Higher Education Funding Council for England (HEFCE) under the Higher Education Innovation Fund (HEIF Round 3), running in 13 Higher Education Institutes (HEIs) in the UK between 2006 and 2008 and leading to successor projects. (p. 603)

SPEED was an experimental program that investigated the theory of learning by doing in students at the university. In this case, the doing was creating new business models. Forty-three percent of 770 ventures were in the creative industries or related to the creative industry sectors. The initial concept of SPEED "was developed by Birch (Staffordshire University) and Clements (University of Wolverhampton) in 2005, who recognised the unrealised potential of enabling entrepreneurial students to start business ventures during their studies as work experience projects, forming an alternative to conventional work placements" (p. 607). Meanwhile, its aim was "to facilitate student skills of enterprise and creativity, enabling potential entrepreneurs to test out business concepts and produce new graduate enterprises" (p. 607). Students could pragmatically acquire practical entrepreneurial skills and business management knowledge for sustaining their new ventures. Moreover, entrepreneurship education among HEIs would be able to renew their approaches if the program was successful, which it was.

The SPEED program started in 2006, and ran for thirty months. It included thirteen institutions, twelve English universities and one in Northern Ireland, contracted with $£ 5$ million. 
Sixty-three percent of participants were males and thirty-seven percent were females. The subject areas involved were $22 \%$ business, $28 \%$ art and design, and the rest were engineering, computing/IT, sports, performing arts, etc. Most of the participants were in their second year (full-time) or in their third year (part-time). Categories of ventures that student developed were design and retail (15\%), services, media, and IT (13\%), and others were divergent. "Creative business, including photography, media, marketing design and product design, constituted 43 per cent overall" (Rae, 2012, p. 608).

Rae analyzed one-hundred enterprises and identified four types of ventures (see Table 1). Type 1 were creative design and production enterprises ( 27 ventures). They included fine arts (ceramic, glass, and sculpture), furniture and lighting design and production, craft production, fashion design and production, landscape design, and garden design. Type 2 were performance and experience enterprises (15 ventures), which included event and festival promotion, music promotion and staging, fireworks display, and creative travel experience. Type 3 were digital, media, and promotion enterprises (49 ventures), including photography, video production, marketing and advertising, magazine and book publishing, IT and gaming, graphic design, and web design. Finally, type four were trading enterprises ( 9 ventures), including online retailing, art dealing and gallery management, fashion retailing, and memorabilia sales. 
Table 1

100 Creative Enterprises in the SPEED's Program

\begin{tabular}{|c|c|c|}
\hline Type & & Subtype \\
\hline \multirow[t]{6}{*}{ Type 1} & \multirow[t]{6}{*}{ Creative design and production } & Fine arts - ceramics, glass, sculpture \\
\hline & & Furniture and lighting design and production \\
\hline & & Craft production \\
\hline & & Fashion designer maker \\
\hline & & Landscape and garden design \\
\hline & & Total: 27 \\
\hline \multirow[t]{5}{*}{ Type 2} & \multirow[t]{5}{*}{ Performance and experience } & Event and festival promotion \\
\hline & & Music promotion and staging \\
\hline & & Firework display \\
\hline & & Creative travel experiences \\
\hline & & Total: 15 \\
\hline \multirow[t]{7}{*}{ Type 3} & \multirow[t]{7}{*}{ Digital, media and promotion } & Photography \\
\hline & & Video production \\
\hline & & Marketing and advertising \\
\hline & & Magazine and book publishing \\
\hline & & IT gaming \\
\hline & & Graphic and web design \\
\hline & & Total: 49 \\
\hline \multirow[t]{6}{*}{ Type 4} & \multirow[t]{6}{*}{ Trading } & Online retailing \\
\hline & & Art dealer and gallery management \\
\hline & & Fashion retailing \\
\hline & & Memorabilia sales \\
\hline & & Total: 9 \\
\hline & & Overall total: 100 \\
\hline
\end{tabular}

Rae (2012) discovered that subjects presented diverse motivations toward creative enterprises, "some aspiring to make their creative output into a business, others primarily interested in furthering their creative practice, for which generating an income from business activity was necessary but not a prime aim" (p. 615). Subjects who did not consider turning their ventures into sustainable businesses were defined as learning failures. Those who used their creative skills to design and develop businesses with successful solutions were strongly intending to continue their businesses. 
SPEED was recognized as "an innovative and largely effective programme" (Rae, 2012, p. 618) for students to be trained in the knowledge-based, creative, and digital economy. Because of increasing tuition fees, lack of governmental teaching grants for arts and humanities, and severe competition in the labour market, arts and humanities majors have to deal with the risk of unemployment. "Hence creative entrepreneurship can make an increasingly important contribution to bridging the widening gap between higher education and graduate employment in this economic context” (Rae, 2012, p. 618). The SPEED program brought different categories together and intertwined entrepreneurship education, creativity, and design into a new approach—creative entrepreneurship education.

2.7.2 "Design Direct: How to Start Your Own Micro Brand." "Design Direct" was a six-week workshop course for postgraduate design students. The workshop was coordinated by Roger Ball, a professor of industrial design and the leader of Master of Design Practices and the Asian Ergonomics Lab, and his colleague, Ernesto Spicciolato, in the School of Design at the Hong Kong Polytechnic University (HKPU) in 2012. In this six-week workshop course, nineteen students practiced how to develop their own micro-brands. During the course, students had to create a profile, equivalent to a business plan, for their micro-brand. Students also needed to build prototypes and make viable products (Ball \& Overhill, 2012).

Experienced and successful mentors were invited to advise students before they started their practices. Students were required to accomplish several assignments. The first exercise was a brand profile (see Figure 2), which outlined the structure of the brand's development. The second one, business proposition, required students to answer three questions:

1. What is your brand idea? (Description)

2. How is it new or different from existing products? (Innovation) 
3. How will it improve the customer's life? (Benefit) (Ball \& Overhill, 2012, p. 98)

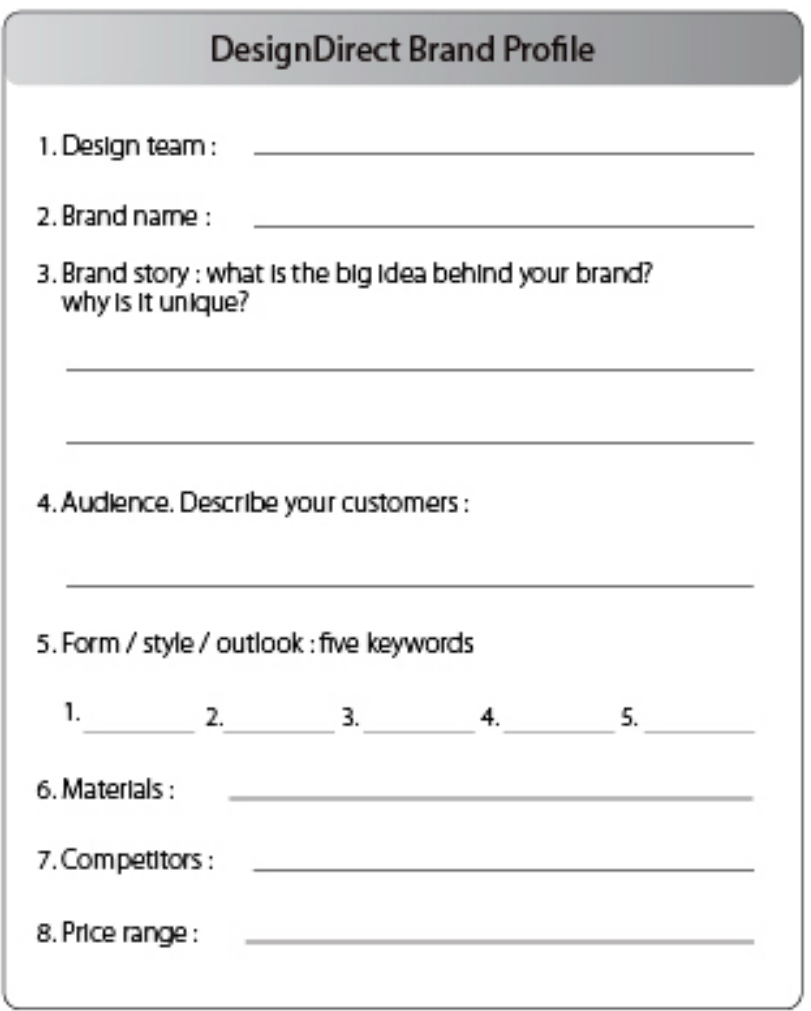

Figure 2. The brand profile. (Ball \& Overhill, 2012, p. 97)

The third exercise was public speaking and visuals. It required students learn how to do formal business presentations, particularly presenting business plans because most design students do not have these kind of skills (Ball, 2002). Brand name and strategy was the fourth exercise. Students were asked to create a unique brand name for their micro-brand. Strategy related to learning how to develop business models for their brands. The final exercises were website and web search optimization, which allowed students to learn how to do e-commerce. These exercises familiarized students with business, branding, management, and entrepreneurial knowledge, albeit in a very short period. For example, teams were required to do a three-minute 
video advertisement about their brand. This was considered as a part of the branding exercise. Moreover, teams needed to develop a website or use online social networking service (SNS), such as Facebook, YouTube, and Twitter to create a brand page. When teams' proposals and brand products were confirmed by the coordinator and advisor, teams had to utilize rapid prototyping techniques, such as computer-aided design (CAD), computer numerical control (CNC), and 3D printing machines, to make their prototypes.

Compared to SPEED, this program was a short workshop course. However, the aim of this course was educating designers to be prepared for modern working environments in the knowledge-based economy. Particularly, it brought entrepreneurial thinking to design students in order to familiarize designers with branding, perceiving issues of intellectual property, ecommercialization, marketing, advertising, business strategy development, management, etc. (Ball \& Overhill, 2012; Gunes, 2012).

\subsection{Rationales for Creative Entrepreneurship in Design}

The reason for approaching creative entrepreneurship in design education in China is not because current educational modes in China's design are irrelevant. It is because this new hypothetical approach offers a new orientation to design education in China (see Figure 3). The new hypothetical approach is something that the labour market has been yearning for many years. For those design graduates who intend to establish their own businesses, this approach provides a new platform to aid them. Presumably, the majority of designers do not take business courses during their academic years in China. Missing managerial and entrepreneurial knowledge will make young designers spend extra effort and time to familiarize themselves with their career milieus, especially for those who are going to work for multinational organizations. Ball's (2002) study argues that the problems that have slowed down creative individuals' career 
success are primarily a lack of business and entrepreneurial knowledge. Fung and Lo Choi's (2001) study shows that companies in China complain about the skills and knowledge of design graduates, which are too narrow. Their findings suggest that "design students are not relevant to modern-day socio-economic circumstance" (p. 176).

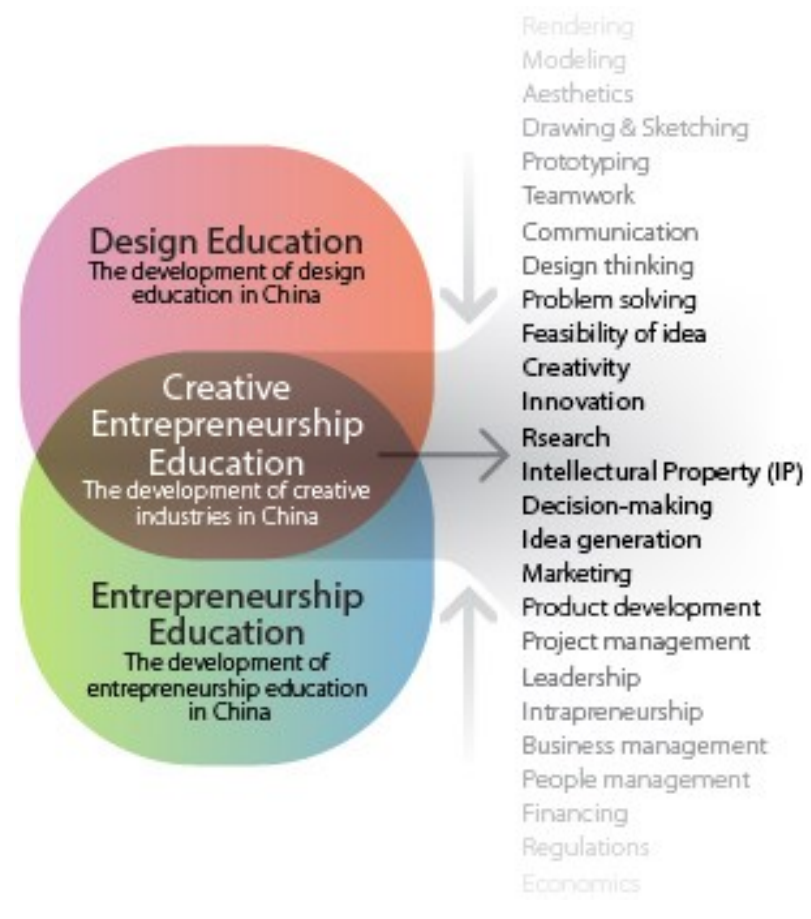

Figure 3. The model of creative entrepreneurship education.

Subsequently, the creative economy needs more creative clusters, participants, and entrepreneurs to flourish its development (Flew, 2012; Florida, 2002; Keane, 2013; Li, 2011). Designers are candidates who have creative and innovative skills, passion, ideas, and talents to thrive in creative industries. Unfortunately, Chinese designers lack managerial and entrepreneurial skills and knowledge. In Li’s (2011) study, the majority of creative enterprises in China are SMEs. The most effective development for SMEs is to embolden more and more 
talented graduates to become SMEs creators (Galloway \& Brown, 2002; Gibb,1997; Jack \& Anderson, 1999; Nabi \& Holden, 2008). However, in China, entrepreneurial programs for creating businesses in practice do not exist in both business and design schools. Inserting entrepreneurship into design education would particularly bring the concept of creating start-ups to design education. Not only could establishing programs similar to SPEED and "Design Direct" offer more opportunities for designers who are willing to become nascent entrepreneurs but these programs also could provide more contributions for developing creative industries in China.

In fact, the present circumstance in China has changed. Firstly, resources and technologies for minimal production are possible today. Young designers can easily embrace technologies such as CAD software, 3D printers and scanners, and CNC machines. Secondly, promotion platforms for new start-ups are prevalent in China now, particularly platforms on the internet and mobile networks (e.g., Taobao, Weibo, WeChat, etc.). Thirdly, innumerable crowdfunding platforms in China offer an easy way for young graduates to gather funds for startups (Bischoff, 2014; Xiang, 2015). Fourthly, e-commerce in China has undergone unimaginable developments (Dobbs, et al., 2013). Online shopping has become an irresistible part of people's daily lives. This ubiquitous phenomenon exists because online shopping is convenient compared to street shopping, and there are over one-hundred million mobile users in China.

Finally, the contemporary consumeristic culture in China is entirely diverse compared to the past. The major consumeristic generation in China will be those who were born in the late 1980s, the 1990s, and the early 2000s. They have become the pillar of economic contribution in China. Their culture, behaviour, mentality, and values are completely different from their parents. They are more individualistic. They are the experts of new technologies. They prefer 
shopping online instead of shopping in stores. They are looking for products that have a unique design, can represent their identities, and are not mainstream (Justice, 2012; Sinha, 2008; Yu et al., 2007). This diversity divides the consumer market into enormous amounts of small segments. Each segment will have enough customers to support it.

Conversely, design graduates who do not want to become self-employed people or entrepreneurs can also benefit from entrepreneurial education. Giudice and Ireland (2014) claim that the future world needs leaders who are either from the business world and fully understand design or from the design world and fully understand business. In other words, design and business management should be synthesized. Design and business should not be separated (see Figure 4). Because the majority of lucrative conglomerates in China are still run by state owned enterprises (SOEs), foreign joint ventures (FJVs), and foreign owned enterprises (FOEs), if young designers want to be recruited by these colossal organizations, they need to meet or exceed these organizations' requirements. Designers who have basic entrepreneurial and business management knowledge will thrive faster and more efficiently compared with those who do not. 


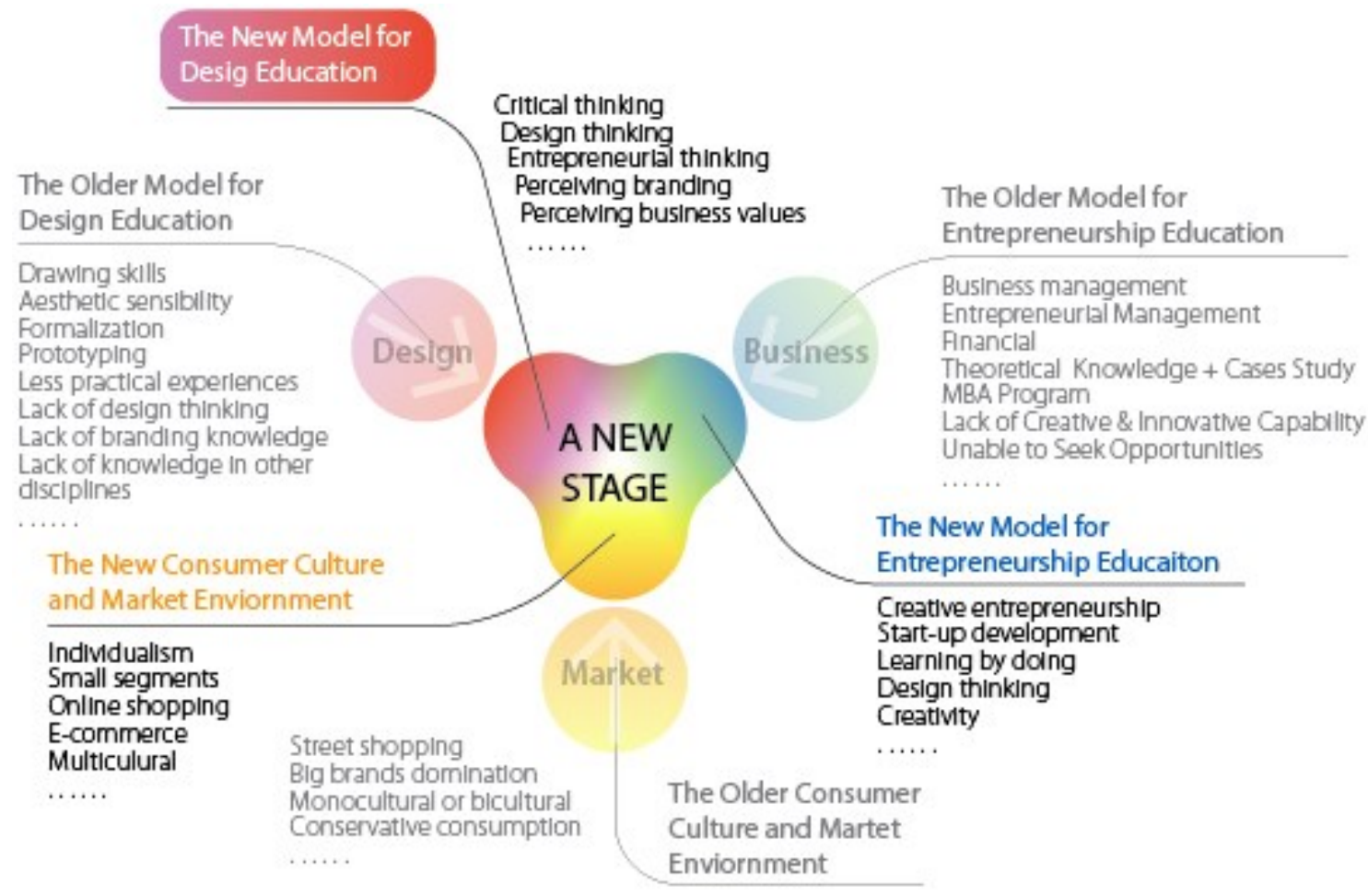

Figure 4. The new model for design education in China.

In sum, because of simple technologies, the internet, online social media, and ecommerce, young designers can easily transform their ideas and concepts to authentic products or services. In other words, people can easily create start-ups, develop their own brands, and make things (Anderson, 2012; Ball \& Overhill, 2012). Hypothetically, creative entrepreneurship education can facilitate these possibilities and provide solid foundational skills and knowledge to young designers in the knowledge-based economy in China. In addition, creative entrepreneurship education also aids designers in accessing the organization world more easily and helps them become successful in the organization world faster. However, in order to propose creative entrepreneurship education for design students in China, studies considering designers' 
entrepreneurial aspirations and intentions are a prerequisite. The next section explains what entrepreneurial aspirations, intentions, and motivated factors are.

\subsection{Entrepreneurial Aspiration, Motivation, Intention, and Driver (EAMID)}

Studies have shown that creative graduates have the entrepreneurial characteristics and intentions of being self-employed or freelancers in the UK (Ball, 2002; Carey \& Naudin, 2006; DCMS, 2006). This directly generates developing entrepreneurship education for creative and design education in HEIs in the UK. More importantly, although creative entrepreneurship education in the UK has only been developed for a short period, the motivations and drivers for its development at the national level are clear-economic sustainability and growth (DCMS, 2006). At the individual level, creative graduates' entrepreneurial aspirations and intentions also urge the UK's HEIs to develop the creative entrepreneurship education. In China, the motivations and intentions for developing creative industries at the national level are also plain. However, at the individual level, entrepreneurial aspirations and intentions among creative graduates are still unknown. In order to understand entrepreneurial aspirations, motivations, and intentions among creative individuals, research needs to explain what entrepreneurial aspirations, motivations, and intentions are.

2.9.1 The theory of planned behaviour (TPB). From a cognitive-psychological perspective, in his study, "The Theory of Planned Behavior," Ajzen (1991) suggests that "intentions to perform behaviors of different kinds can be predicted with high accuracy from attitudes toward the behavior, subjective norms, and perceived behavioral control; and these intentions, together with perceptions of behavioral control, account for considerable variance in actual behavior" (p. 179). In Ajzen's explanation, "attitudes toward the behavior," "subjective norms", and "perceived behavioral control" are the key players for predicting intentions. 
Attitudes toward the behavior refers to favorable or unfavorable evaluations or aspirations that are based on individuals' attitudes. Subjective norm refers to external influence, or social pressure. Perceived behavioral control refers to decisions, impediments, and obstacles for the preforming behaviours reflected by past-experiences. All three of these key players are affected by salient information and beliefs, which can be seen in Figure 5. Attitudes toward the behavior are assumed to be influenced by behavioural beliefs. Subjective norms are constituted by normative beliefs, and controlling beliefs provides the basis for perceived behavioural control.

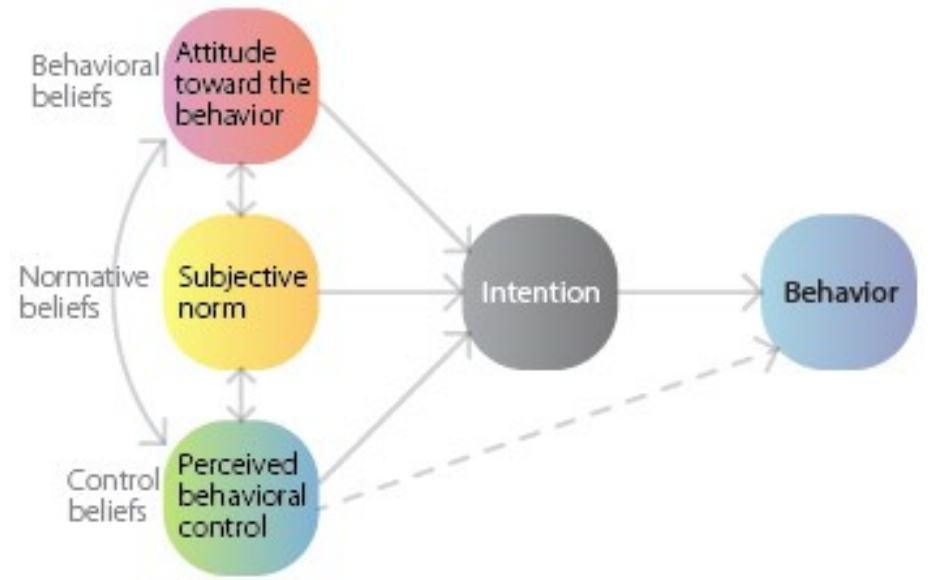

Figure 5. The model of the theory of planned behaviour. (Ajzen, 1991, p. 182)

Ajzen (1991) explains that behavioral beliefs refer to individuals' attitudes, and "attitudes develop reasonably from the beliefs people hold about the object of the attitude" (p. 191). Normative beliefs refer to concerns with "the likelihood that important referent individuals of groups approve or disapprove of performing a given behavior" (p. 195). Control beliefs "may be based on part on past experience with the behavior, but they will usually also be influenced by second-hand information about the behavior" (p. 196), such as the shared experiences of friends 
or other people. In sum, "intentions are assumed to capture the motivational factors that influence a behavior; they are indications of how hard people are willing to try, of how much of an effort they are planning to exert, in order to perform the behavior" (Ajzen, 1991, p. 181). In other words, intentions are the motivations of individuals' behaviours, and individuals' behaviours are the outcomes of their intentions. Intentions are generated by individuals' attitudes that come from individuals' beliefs (see Figure 6).

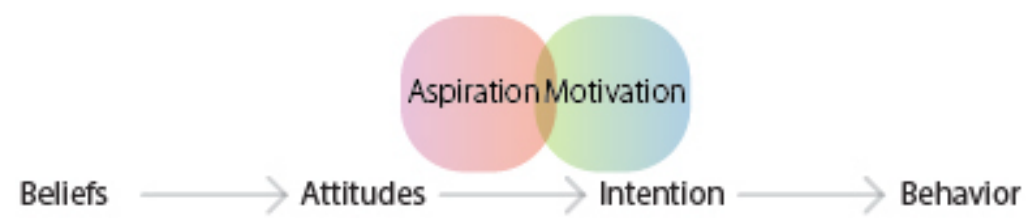

Figure 6. An adapted linear illustration of beliefs to behavior (Boyd \& Vozikis, 1994).

2.9.2 Entrepreneurial intentions (EIs). Based on Bird's (1988) study, entrepreneurial intentions (EIs) refer to "entrepreneurs' states of mind that direct attention, experience, and action toward a business concept, set the form and direction of organizations at their inception" (p. 442). In other words, EIs are the outcomes of rational analytic, intuitive, and holistic thinking that are based on entrepreneurs' personal experiences and beliefs (Boyd \& Vozikis, 1994). Motivations for creating an enterprise, or EIs, play significant roles in the development of nascent entrepreneurs (Boyd \& Vozikis, 1994; Krueger, Reilly, \& Carsrud, 2000). Therefore, EIs become a critical measurement for predicting potential entrepreneurship. Moreover, intentionality is affected by internal factors, such as personality, abilities, skills, and knowledge, and external factors, such as socio-political environments and market tendencies (see Figure 7). 
These internal and external factors will affect individuals' intentions about developing a new enterprise or not.

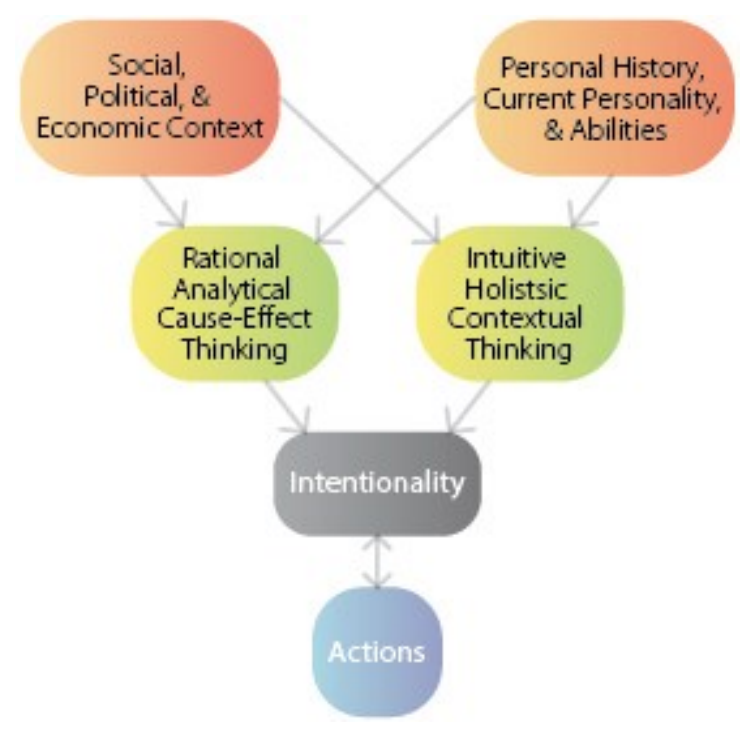

Figure 7. The model and contexts of intentionality (Bird, 1988, p. 444).

2.9.3 The relation between entrepreneurial motivations and drivers. From Ajzen's model (1991) of the theory of planned behavior to Bird's model (1988) of EIs, entrepreneurial aspirations are formed by individuals' beliefs and attitudes, which are affected by internal and external factors. Entrepreneurship or entrepreneurial activities are driven by entrepreneurial motivations and EIs. Entrepreneurial motivations refer to individuals' motivations for developing their own businesses. Their motivations come from internal factors, external factors, or both. For instance, family members, friends, or classmates, or colleagues (external influences) might motivate an individual who is considering developing a business. When an individual has a good idea or recognizes an opportunity for developing a business, this individual is motivated by his or her internal factors. Shane, Locke, and Collins (2003) suggest several concepts of entrepreneurial 
motivation (e.g., the need for achievement (nAch), risk-taking, tolerance for ambiguity, locus of control, self-efficacy, goal setting, independence, drive, and egoistic passion).

The concept of the need for achievement (nAch) was first propounded by McClelland (as cited in Kirby, 2004). The term, achievement motivation, also relates it (Shaver \& Scott, 1991). It was used to describe individuals who have high levels of the nAch. They tend to be more responsible than those who have a low nAch. Individuals who have high levels of the nAch desire to accomplish tasks and tackle problems. The conclusion of Shane et al. (2003) suggests that the nAch is only appropriate as a tool for differentiating between firm founders and general populations.

Risk-taking propensity is considered as another motivation of interest (Shane, Locke, \& Collins, 2003). It refers to individuals' abilities to coping with ambiguity and uncertainty. This quality more often exists in entrepreneurs than non-entrepreneurs (Kirby, 2004). However, "the measurement of risk-taking propensity may be confounded with high self-efficacy" (Shane et al., 2003, p. 265).

Tolerance for ambiguity means "individuals perceive ambiguity when they lack sufficient cues to structure a situation" (Begley \& Boyd, 1987, p. 83). It is used to measure entrepreneurs' motivations for business development and perseverance because entrepreneurs need to deal with daily uncertainties (Shane et al., 2003).

Locus of control is the "measure [of a] subjects' perceived ability to influence events in their lives" (Begley \& Boyd, 1987, p. 81). Individuals who have a low external locus of control believe their characteristics do not support them in controlling their outcomes, whereas individuals who have a high internal locus of control do (Shane et al., 2003). It is also considered as one of fundamental entrepreneurial attributes (Kirby, 2004). 
Self-efficacy refers to "a person's belief in his or her capability to perform a given task" (Boyd \& Vozikis, 1994, p. 66). If an individual has a high level self-efficacy, this individual will develop better strategies to achieve given tasks, will be dedicated to accomplishing these tasks, and will put more effort into converting negativity into positivity (Shane et al., 2003).

Goal setting, as Shane et al. (2003) suggest, refers to quantitative goal setting. It means that entrepreneurs need to preserve all the outcomes from different tasks pertinent to one standard - business success. For instance, an entrepreneur needs to maintain business growth, provide innovation, and secure financial performance.

Independence also refers to the desire for autonomy. It has been found to be an important entrepreneurial attribute (Kirby, 2004). It is related to “taking responsibility for one's own life rather than living off the efforts of others" (Shane et al., 2003, p. 268).

Drive, as Shane et al. (2003) suggest, is similar to the nAch, but it has broader references. They consider drive to include an individual's ambition, goals, energy, stamina, and persistence for entrepreneurship.

Egoistic passion refers to an individual's passion, enthusiasm, and interest on working or building an organization (Shane et al., 2003). Individuals are particularly motivated by their own interest. For entrepreneurs, egoism is related their personal interest and enthusiasm for selfdevelopment, self-achievement, and self-success.

In fact, many of these concepts are used to identifying entrepreneurial traits, such as risktaking, the need for achievement (nAch), locus of control, tolerance for ambiguity, etc. (Kirby, 2004). However, entrepreneurial motivations can be driven by other factors, such as the threat of unemployment, wealth, self-challenge, etc. (Hessels, Gelderen, \& Thurik, 2008). 
2.9.4 Different levels of entrepreneurial intentions (EIs). Atherton (2007) suggests a transitional process for navigating how an individual goes from having no interest in developing an enterprise to having an interest and finally putting his or her interest into action with five phases. These five phases are "no awareness, awareness, interest, exploration, and engagement" (p. 410). The first stage, no awareness, means that the individual does not have any consideration or recognition about creating a business. The second stage, awareness, means that the individual is considering or recognizing a business opportunity but might still have little motivation. The first transition, from no awareness to awareness, is when an individual moves from never considering any business creation option to considering creating a business but is not considering this option seriously. The awareness of the option could be motivated by friends' entrepreneurship or the threat of unemployment (Atherton, 2007). The third stage, interest, means the individual has a strong interest in the idea of creating a business. The second transition, from awareness to interest, is when the individual realizes that creating the business is a possible and viable option. The fourth stage, exploration, is when the individual starts to form specific ideas about the creation of the business or is exploring possible options for developing the business. During the third transition, from interest to exploration, the individuals' entrepreneurial aspirations for creating the business are strong. The final stage, engagement, means the individual has confirmed his or her intention to creating the business. During this final transition, from exploration to engagement, the individual start to plan or put his or her considerations into action.

Based on Atherton's model (2007), EIs can be divided into five levels, from zero to four (see Figure 9). This transitional model presents the transformation of EIs from mental consciousness to physical action. At level zero, EIs are negative. At level one, EIs become 
slightly negative, but they slightly exist. At level two, the existence of EIs move from slightly negative to slightly positive. EIs become more positive when they arrive at level three. At the final level, level four, EIs drive individuals to start their physical actions to develop a business.

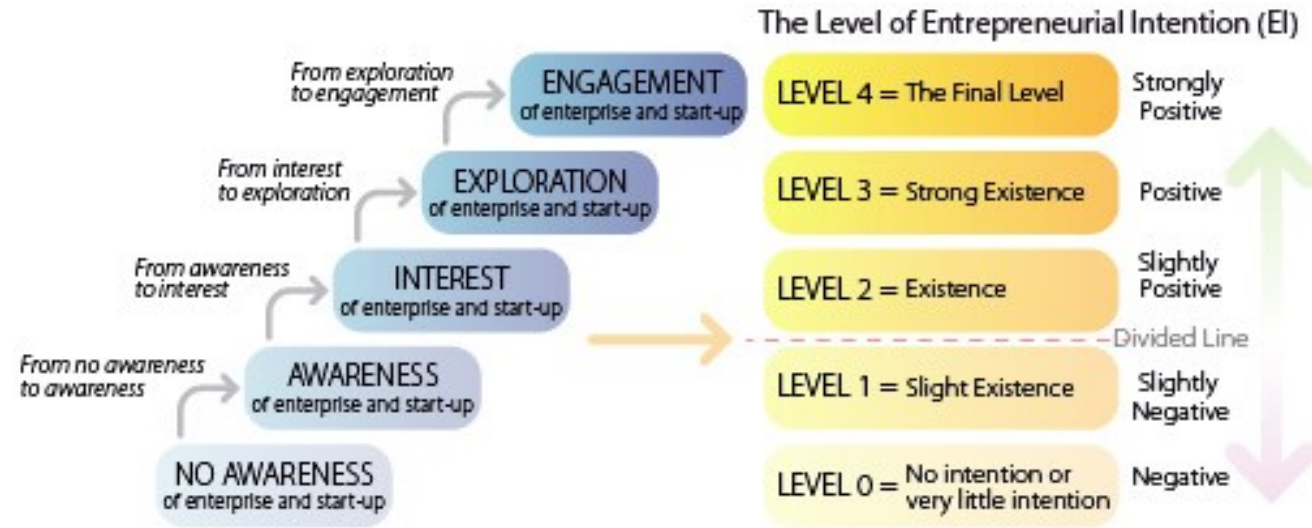

The Extended Pre-Start Model (Atherton, 2007, p.410)

Figure 8. The model in scales' level of entrepreneurial intention (EI).

Figure 8 depicts how potential entrepreneurs move from having no intention of creating an enterprise to confirming their ideas or plans for developing an enterprise as they are driven and motivated by their intentions (entrepreneurial intentions). From the phase of no awareness to awareness, individuals start to have EIs, but their EIs are still negative. From the phase of awareness to interest, EIs start to drive individuals forward to the next phase. In this transition, EIs do not stimulate individuals to start their physical actions until they move to the next transition. From the phase of interest to exploration, EIs become more positive. EIs not only exist in individuals' minds but also motivate individuals to look for feasible opportunities for further enterprise development. From the phase of exploration to engagement, EIs become firm and strong. They lead individuals to start planning for their venture creation or urge individuals 
actually developing their business. This transitional process also presents how potential entrepreneurs become nascent entrepreneurs.

Based on aforementioned explanations, individuals can be divided into two types, $\mathrm{A}$ and B. Type A, individuals do not have any EIs or aspirations, but the other type does. However, type A can also be separated into two types, A1 and A2. Type A1 will never have any entrepreneurial intentions or aspirations, but type A2 may have them because this type of individual may be motivated by internal factors, external factors, or both (see Figure 9). Entrepreneurial awareness may not exist in the beginning, but it will grow later. Individuals' entrepreneurial aspirations, motivations, and intentions can be formed by different factors, which can be internal, external, or both.

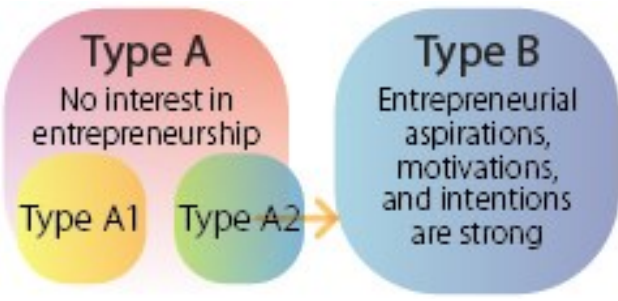

Figure 9. Two types of individuals.

Before putting the hypothetical approach to the agenda of developing creative entrepreneurship education in design education in China, it is worth examining who creative potential entrepreneurs are, or who creative individuals who intend to be self-employed are, among creative graduates. Discerning graduates' motivations for entrepreneurship is necessary. Particularly, for policy makers, educators, scholars, and researchers; they need legitimate data and studies to understand entrepreneurial aspirations, motivations, and intentions among creative 
graduates. Legitimate data and studies can help them to establish policies and strategies for introducing creative entrepreneurship to design education. Entrepreneurial aspirations, motivations, intentions, and drivers are important measurements for identifying potential creative entrepreneurs among creative graduates. Because of this, this study investigates the levels of EIs among Chinese designers and what drivers motivate their intentions. 


\subsection{Methodology}

This research uses mixed methods - a synthesis of quantitative and qualitative research. The reason for this methodology is that mixed methods research "recognizes the importance of traditional quantitative and qualitative research but also offers a powerful third paradigm choice that often will provide the most informative, complete, balanced, and useful research results" (Johnson, Onwuegbuzie, \& Turner, 2007, p. 129).

According to a study conducted by Shane et al. (2003), some drivers motivating individuals' entrepreneurial intentions can be determined through qualitative research, such as independence, drive, and egoistic passion, and some are determined through quantitative research, such as the need for achievement, risk taking, and tolerance for ambiguity. Moreover, this study not only investigates entrepreneurial intentions in creative graduates but also it tries to understand creative graduates' attitudes about introducing creative entrepreneurship to design education in China. In fact, there is lack of prior studies about entrepreneurial motivations and drivers among creative individuals in China. Due to these reasons, the researcher decided to utilize a qualitative method to collect raw data first. After the qualitative data analysis, a questionnaire was developed and conducted as quantitative research (see Figure 10). 


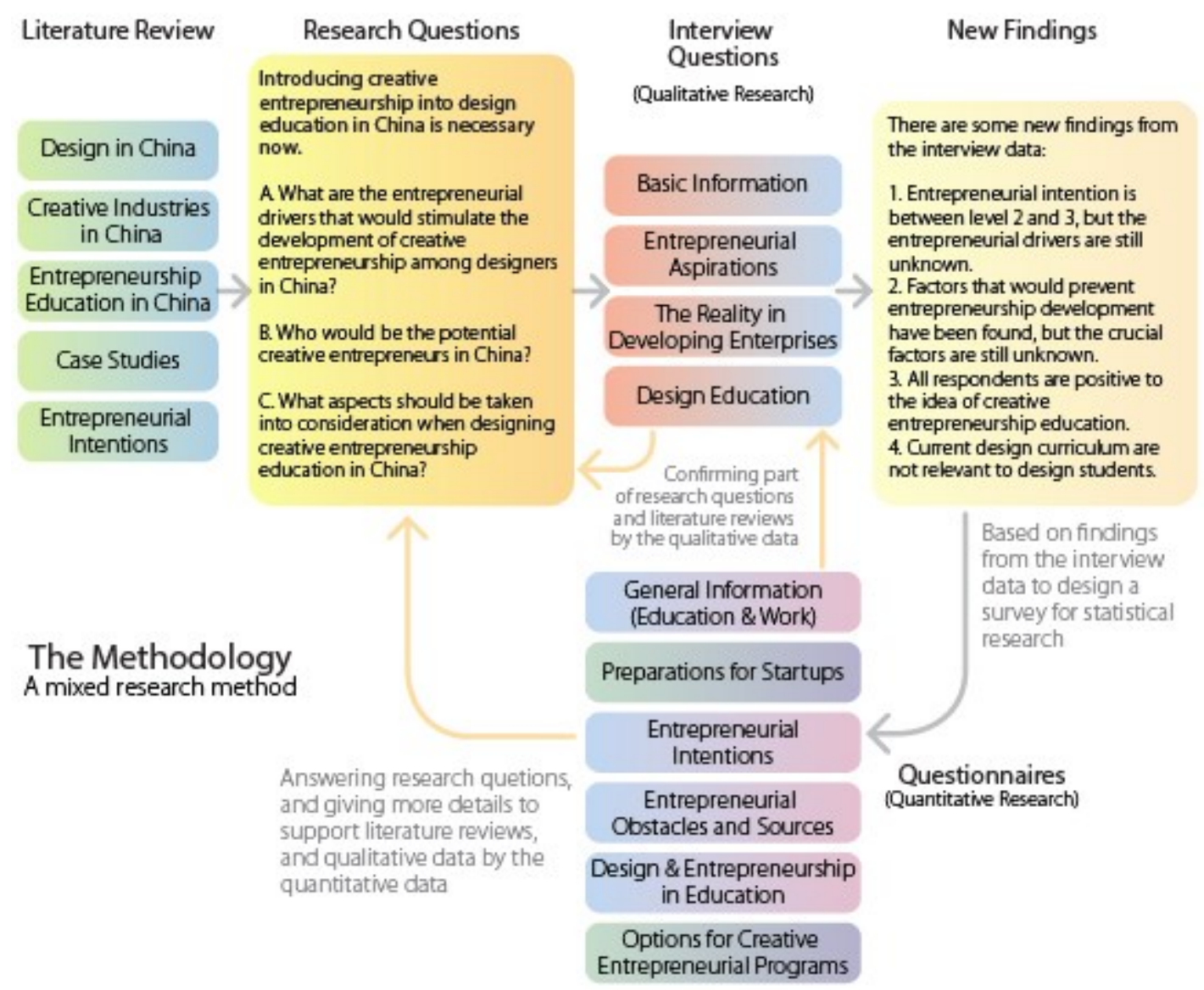

Figure 10. The methodological structure.

\subsection{Research Questions Review}

In accordance with the findings from the literature review, it is logical to conclude that the idea that creative entrepreneurial programs for Chinese designers is feasible. Introducing creative entrepreneurship to design education in China is a legitimate hypothesis. However, entrepreneurial aspirations, motivations, intentions, drivers, and attitudes about creative entrepreneurship education among Chinese designers still need to be investigated. Thus, the following research questions were created: 
1. What are the entrepreneurial drivers that would stimulate the development of selfemployment and entrepreneurship among designers in China?

2. Who would be potential creative entrepreneurs in China?

3. What aspects should be taken into consideration when designing creative entrepreneurship education for designers in China?

\subsection{Qualitative Method - Expert Interviews}

The purpose of the qualitative method was to collect basic information about designers' entrepreneurial aspirations, motivations, intentions, impediments, obstacles for entrepreneurship, and attitudes of introducing creative entrepreneurial education to design education in China. The researcher developed twelve interview questions; two for collecting basic personal information, two regarding entrepreneurial aspirations and intentions, four related to entrepreneurial impediments and obstacles, and four concerning attitudes about creative entrepreneurship and design education (see Appendix 1). All interview questions were developed based on secondary sources and literature reviews. Additionally, due to the attribute of qualitative research, variable settings in this type of research are less rigid (Bouma, Ling, \& Wilkinson, 2012).

3.2.1 Sampling and participants. The researcher used a convenient-purposive sampling method for recruiting interview participants. Their age, gender, educational status, study majors, and working positions were included. The researcher recruited three female and three male participants. These were all young Chinese designers between twenty-three and thirty years old, holding a Bachelor of Design Arts (BDA) degree conferred by Chinese design institutions. Participants were either industrial or graphic designers. They each had at least three months of working experience. The consideration of language in the interview was Chinese, Mandarin. The researcher used his personal and professional network to contact friends and former coworkers 
who are design managers, and asked them to recruit junior designers or young intern designers who were unknown to the researcher as potential interviewees. Next, the researcher contacted the design managers by email with two recruitment inquiry letters, one for design managers and another for potential participants, as well as a participation consent form. Design managers who accepted the researcher's inquiry sent emails containing all of the documents to their junior or young designers. Only those who accepted the researcher's request contacted to the researcher.

3.2.2 Procedures and data. The data in the qualitative research was collected through phone interviews. Each interview was audio-recorded for accuracy and subsequent analysis. The average interview time was thirty minutes. There was no interruption during the interview. Audio records were transcribed into Chinese first and translated into English later. A coding method was utilized to assemble interview data into a limited number of themes and issues that not only pertain to interview questions but also aided in later questionnaire development. Quotations were selected from the interview transcripts that pertained to research questions and themes. Results and findings from the qualitative data were categorized and developed for the quantitative study. The findings and results can be seen in chapter 4.0, Findings and Analysis.

\subsection{Questionnaire (Quantitative Method)}

The researcher used a questionnaire survey set to a large sample population to attest results from the interview data and to find new patterns and factors that motivate designers' entrepreneurial aspirations and intentions. Sixty-seven questions were created for the survey. The questionnaire was divided into four sections, and its contents were presented as follows:

\section{General information section (9 questions)}

\section{a. Gender}

b. Age 
c. Educational background

1) Type of school

2) Type of student

3) Educational status

d. Working information

1) Type of company

2) Position

3) Working categories

4) Years of working

II. Entrepreneurial likelihood (5 questions)

a. Entrepreneur confirmation

b. The first time of thinking about self-employment or entrepreneurship

c. Start-up categories

d. The likelihood of business creation

e. Influential persons

III. The Likert-type scale section (52 questions)

a. Entrepreneurial intentions (17 questions)

b. Motivations and obstacles for entrepreneurship (18 questions)

c. Attitudes about design education in China (17 questions)

IV. Attitude about creative entrepreneurship education (1 question)

In the general information section and the section of entrepreneurial likelihood, questions were designed for single choice selection. In the Likert-type scale section, particularly in the subsections of entrepreneurial intentions and motivations and obstacles for entrepreneurship, 
questions were designed based on Ajzen's (1991) the Theory of Planned Behavior (TPB), factors and drivers related to EIs, Bird's (1988) study, and some motivated concepts based on the study by Shane et al. (2003). Contents were used, such as personal attitudes (attitude toward the behaviour), subjective norm, perceived behavioural control, internal and external factors (EIs), the need for achievement (nAch), tolerance for ambiguity, locus of control, independence, and egoistic passion (or individual passion). In the sub-section of attitude about design education in China, questions were designed based on the literature review and secondary sources. For example, questions were pertinent to the relevance of design curriculums and their content. All fifty-two questions were measured on a seven-point Likert scale, ranging from strongly disagree (1) to strongly agree (7). Details about the survey can be seen in Appendix 2. The survey was designed to be complete in ten to fifteen minutes. It was created in two formats, a Microsoft World file, and an Adobe PDF file.

3.3.1 Sampling and participants. The recruiting method for the survey was slightly different from the recruiting method for the interview. Instead of inquiring through design managers and waiting for potential respondents' permission, an exponential non-discriminative snowball sampling method was utilized for quantitative data collection because of the limitation of time, budget, and distance. The researcher sent an email with one introduction, consent statement, and a survey to the researcher's friends (designers) and former coworkers, asking them to invite designers in their professional networks to complete the survey. The survey was written in Chinese, Mandarin. The span of data collection, from sending out the first survey to receiving the last response, was thirty days.

3.3.2 Procedures and data. The survey data was reviewed by the researcher before coding. The researcher collected 229 responses, and 196 were relevant, so $85.6 \%$ of the surveys 
were valid. The forty-six irrelevant responses were considered as unfinished surveys or were completed by respondents whose degrees were not conferred by Chinese design schools. The researcher encoded the 196 cases into a Microsoft Excel file. Next, data codes were analyzed through the IBM Statistical Package for the Social Science (SPSS), version 22.0. 


\subsection{Finding and Analysis}

Findings and results in this section are separated into two sub-sections. One is interpreting the interview data and the other is interpreting the survey data.

\subsection{Findings from Interviews}

Six participants were interviewed by the researcher. Two of the participants graduated from two different top design schools at the national level, and four graduated from renowned design schools at the level of regular public universities. Only one participant had been working for four years. The others had been working for less than three years.

4.1.1 Entrepreneurial aspirations and intentions. Findings from respondents' answers for interview question 2.1 (have you considered being a creative entrepreneur, entrepreneurial designer or self-employed person, why and why not) showed that entrepreneurial intentions (EIs) among both female and male participants existed, but the levels were different. Male participants' EIs developed slightly earlier than females. Males' EIs existed when they were in university. Females' EIs developed after one or two years of working. For example, one male participant said, "I have considered it. When I was in college, the first time I participated in an association that was a group related to entrepreneurship; so, it provided some activities for students related to entrepreneurship. Apparently, I encountered entrepreneurship quite early, and I was interested in it." One female designer said, "I had this idea probably when I was in my second year of work; when you work a bit longer, you will gradually come to understand your own situation better."

In terms of the level scale of entrepreneurial intentions (see Figure 8), both females and males' EIs were placed between level 2, slightly positive, and level 3, positive. Their interests in entrepreneurship and creating their own businesses were slightly strong. Some of them had even 
been starting to explore resources and opportunities for developing business. However, their EIs still need time to develop to the final level. Additionally, the findings for females' and males' experiences, in answer to interview question 2.2 (what kind of reasons or influence have caused you to consider becoming an entrepreneur or self-employed person) were various. One female and one male believed that their entrepreneurial intentions were not influenced by anyone. Alumni were seen as external motivators by one female and one male participant. The other participants gave varying answers (i.e., social celebrities, family members, and peers).

4.1.2 Entrepreneurial impediments and obstacles. Findings based on the answers to interview question 3.1 (what would be the obstacles that hinder you from starting a new, selfemployed venture) were diverse between female and male participants, but in answer to question 3.2 (what resources do you think would help you go through the barriers of starting a new brand or being self-employed) females and males had some commonalities. Keywords mentioned by female participants for question 3.1 were the following: business opportunity, business model, technologies, business knowledge, self-efficacy, knowledge of developing a business, production, and pricing. In contrast, male participants expressed concerns about personal skills and working experience, teams' development and support, dreams, and economic environment. These were found to be the major concerns that affected participants' intentions to create their own businesses. The only common concern that was raised by both female and male participants was capital. However, in the findings for questions 3.2, partners, teams, and mentors were mentioned by both male and female participants. Exterior motivating factors for each side were found to be incubated platforms, personal efficacy, and start-up aiding associations. Surprisingly to the researcher, Guanxi network (a personal social network) as one of important resources for 
starting and succeeding business (Taormina \& Lao, 2007) was only mentioned by one male participant.

Replies to interview question 3.3 (if you know some of your friends, family members, or peers who have been already running their own creative ventures, what kind of creative ventures are they doing and why) and question 3.4 (why do you think there are not many designers (industrial/product designers) starting their new ventures) were quite negative. On the one hand, all participants told the researcher that they had either met or knew designers who were running their own business or had heard their friends or peers (designers) mention someone who was running his or her own business. On the other hand, based on participants' responses, creative entrepreneurs who are operating design-consulting firms were more numerous because operating design-consulting firms is easier than running business combining designing, making, branding, and selling products. However, in both situations, the number of creative entrepreneurs is few. For instance, one male participant said, "They are operating their own brands, but very few of them do this. As far as I know, most of them are in the category of services, opening design firms serving their clients. This category includes a certain amount of them and perhaps close to $80 \%$ of them."

Findings explain that there are very few creative entrepreneurs because designers do not have knowledge about other disciplines. Particularly, they lack knowledge about business, production, marketing, branding, strategies, etc. In synthesis, designers lack entrepreneurial knowledge, skills, and experience. For instance, one female participant who was working in an innovative company explained the following to the researcher:

They will be thinking about products from a users' point of view, or they will focus on a product per se. The weak point for them is thinking about products from a business 
perspective. They have difficulties in investigating whether a product will really generate business value or not or how much business value can be produced by this product. They rarely look from this angle to think about a problem. This is a relatively large weakness of designers, who are creating their own brand or business. They do not know about how business and economics work.

4.1.3 Attitudes about creative entrepreneurship and design education. The findings based on the answers to interview question 4.1 (why do you think there are no creative entrepreneurial/business curricula for designers in design education in China) can be categorized into three reasons. The first reason is the sluggish development of design education. Participants considered creative entrepreneurial education to be a novel and advanced topic in current design education in China. The current system of design education still needs time to evolve. The second reason is that there is lack of studies and research about entrepreneurship education in design. Teachers and lecturers do not know how to catch students' entrepreneurial aspirations, motivations, and intentions, and students are not enthusiastic about entrepreneurial programs because they never have a chance to experience or learn about it. Finally, the current system and structure of China's design education are disorganized. Many design schools do not know how to systemize their programs and curricula. Some of them duplicate other design schools' outdated curricula and use these outdated curricula for teaching.

In the findings based on the answers to interview question 4.2 (what are your opinions about introducing creative entrepreneurial programs into design education in China) all participants positively considered that introducing creative entrepreneurial programs to design education in China is a great idea. In their answers to interview question 4.3 (as an incumbent designer in practice, would you suggest adding any coursework to the design school that you 
graduated from, in order to benefit students) participants suggested adding new programs that blend theoretical teaching and practical experiment. Moreover, participants also suggested that design schools should provide interdisciplinary programs to students. For instance, business courses or courses related to business were suggested by two participants. One female and male participant mentioned adding courses of design research, design thinking, and design methods. Participants' answers to the last interview questions were different. Two female participants stated that preferred creative entrepreneurial programs that are business-oriented, but one female participant had no specific preference. Two male participants were found to prefer both businessoriented and design-oriented programs, and one male participant selected design-oriented.

In sum, some issues that were addressed in the literature review were corroborated by participants' responses. For instance, design students' capacities are too limited. They are too concentrated on drawing, sketching, modeling, and rendering. The educational developments in new and unpopular design schools are far behind those of the top design schools. Moreover, the findings found that the level of entrepreneurial intention among Chinese designers is between level 2 and level 3. In other words, Chinese designers are positively interested in business creation, and they want to explore opportunities for creating ventures or brands. Based on the findings from the interview data, because designers lack entrepreneurial knowledge, skills, and experience, their desires for entrepreneurship cannot be fulfilled. The findings merely demonstrate some evidence, such as the specific levels of designers' EIs and some factors and drivers for entrepreneurship existing among a limited number of subjects; however, the findings do not explain what kinds of motivated factors and drivers for entrepreneurship exist in certain types of designers, offer suggestions for developing creative entrepreneurial education based on the existing motivated factors and drivers, or a way of identifying who potential creative 
entrepreneurs may be. In order to investigate and answer research questions completely, all findings from the interview data were used to develop a questionnaire survey. The next section explains the findings from the statistic data that was collected from 196 Chinese designers' survey responses.

\subsection{Findings from the Survey}

Because a number of variables were set in the survey, and because the number of respondents was high, the outcomes from this statistic analysis are complex and rich. In order to dismantle the complexity of the process of acquiring the findings from the survey data, the findings in this section are divided into four sub-sections, general analysis (frequency distribution analysis), factor analysis, cluster analysis, and cross-tabulations analysis (crosstabs analysis).

General analysis in this section uses a frequency distribution (FD) method to summarize how the values of each categorical variable were distributed in the general information section. Categorical variables "are those for which the value indicates different groupings" (DeCoster, 1998b, p. 4) such as gender, age, and type of students. FD provides representative percentages and values between variables (e.g., female verses male, students who graduated from tier one schools verses students who graduated from tier two and three schools, etc.).

Factor analysis is used to collect and "examine how underlying constructs influence the responses on a number of measured variables" (DeCoster, 1998b, p. 1). In other words, it is used to examine similar patterns based on each response from the Likert-type scale section. In this study, factor analysis is used to review the drivers of entrepreneurial intentions. Particularly, it is used to investigate similar features regarding entrepreneurial intentions, and motivations and obstacles for entrepreneurship. For instance, each respondent gave either similar or different 
responses to each item (question) in the Likert-type scale section. Factor analysis was used to discover similarities among responses. The consistency of similarities was categorized based on the Kaiser-Meyer-Olkin (KMO) measurement, which is a commonly used measure for factor analysis (more than 0.70 is good and more than 0.50 is acceptable) (Hair, Black, Babin, \& Anderson, 2009).

Cluster analysis is based on a mathematical method to group similar objects into sets from a data (Romesburg, 2004). "Objects with similar descriptions are mathematically gathered into the same cluster" (p. 2). In the survey findings, clusters are grouped from objects that are discovered from the factor analysis because factor analysis has already highlighted significant factors, or objects. If the researcher had used cluster analysis to group similar objects from variables in sub-sections it might not have been easier to discover and interpret significant clusters from all variables.

Crosstabs analysis is used to "compare two categorical variables by showing a table with the classes of one variables as the rows and the classes of the other variable as the columns" (Pontius \& Cheuk, 2006, p. 2). In the survey data, crosstabs analysis was used to discover if there were significant differences in responses between different items (questions). The significance or results were calculated based on the Pearson Chi-square measurement, which is $<0.05$. In sum, all the analyses, general analysis, factor analysis, cluster analysis, and crosstabs analysis are based on a linear process. Only significant results were addressed and interpreted in each analysis.

4.2.1 General analysis - Frequency distribution (FD). In Figure 11, it can be seen that female respondents constituted $40.8 \%$ (80) of the total respondents, and male respondents accounted for $59.2 \%$ (116). The biggest age group in both female and male respondents was the 
group of those between the ages of twenty-three and twenty-sex years old. This group accounted for $44.4 \%$ of the total respondents. The second biggest group was those between twenty-seven and thirty years old (see Figure 12). Ninety-two female and male respondents (46.9\%) graduated from tier one design schools (at the national level), seventy-five $(38.3 \%)$ of respondents earned their degrees from regular and renowned design schools (tier two), and twenty-nine (14.8\%) were educated at design schools at the level of colleges and private institutions (tier three) (see Figure 13). Respondents with educational background in arts and humanities constituted $66.8 \%$ (113) of respondents and science and engineering students accounted for 33.2\% (65) (see Figure 14).

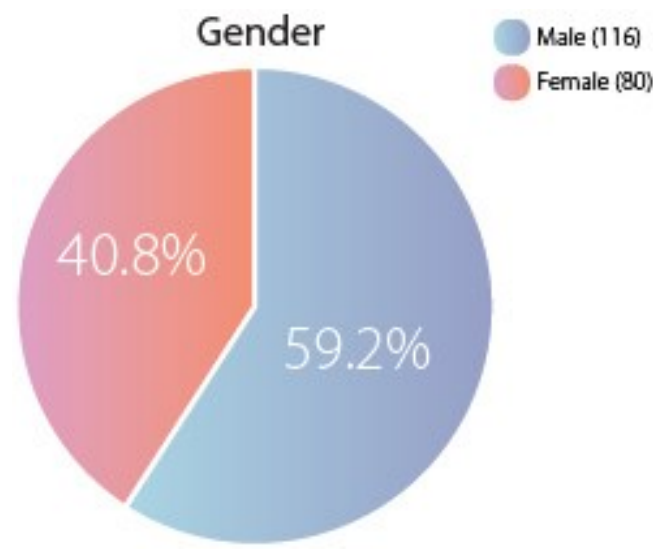

Figure 11. The values of respondents based to gender.

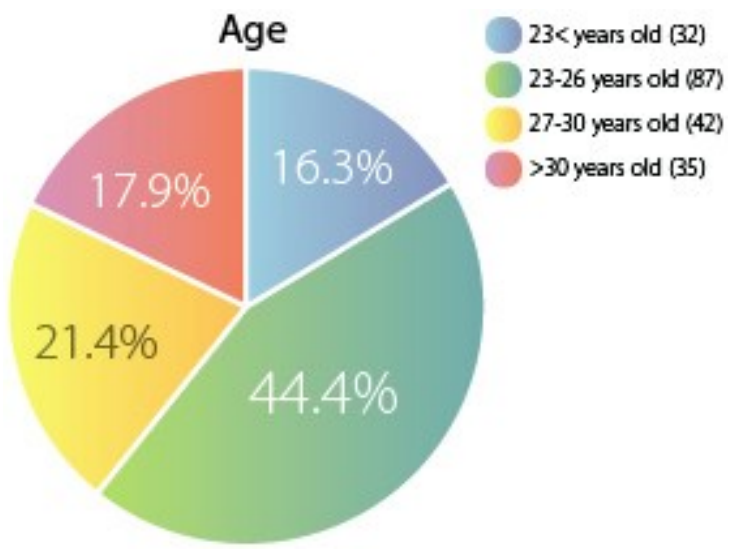

Figure 12. The values of respondents based to age 


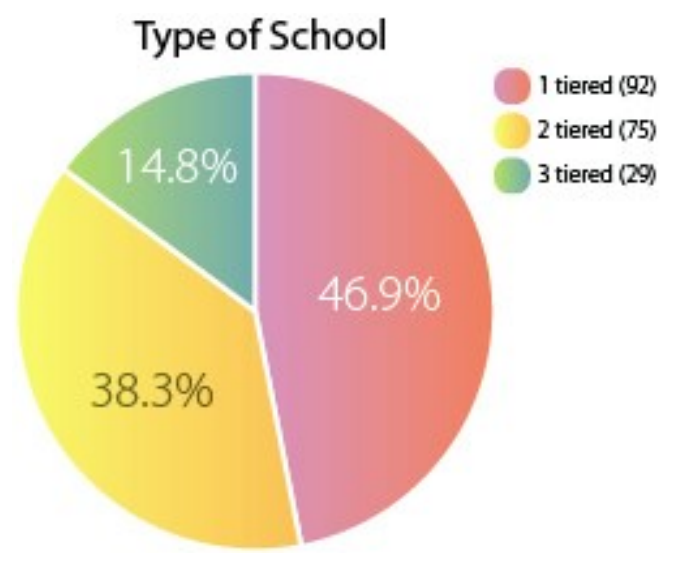

Figure 13. The values of respondents based to type of school.

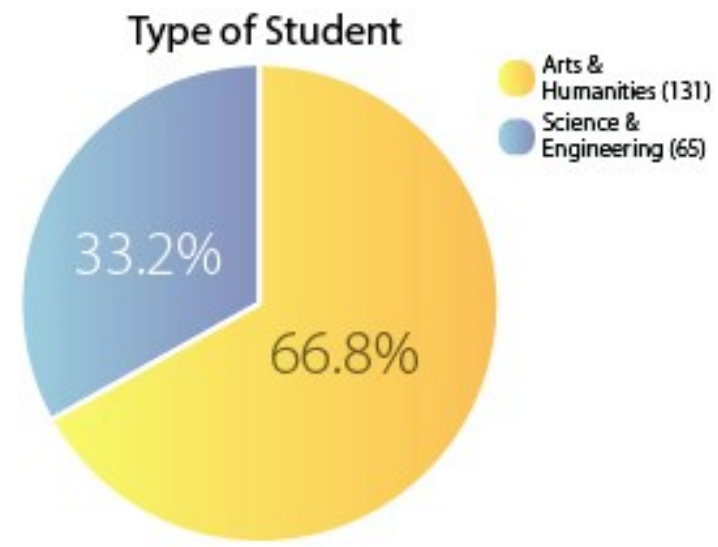

Figure 14. The values of respondents based to type of student.

One hundred and fifty-eight respondents $(65 \%)$ had bachelor's degrees, thirty-eight had master's degrees (19\%), twenty-five (12.8\%) had diplomas or associate degrees from college, three had Ph.D. degrees, and one had a middle-high school diploma (see Figure 15). Respondents who work for design consulting firms or companies whose major business is pertinent to design services accounted for $48.5 \%$ (ninety-five). Others, who work for companies that are not design firms, accounted for 51.5\% (101) (see Figure 16). 


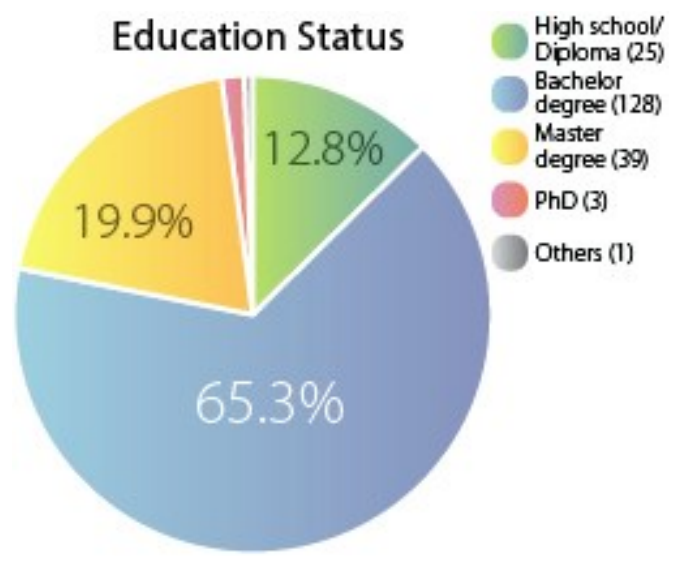

Figure 15. The values of respondents based to education status.

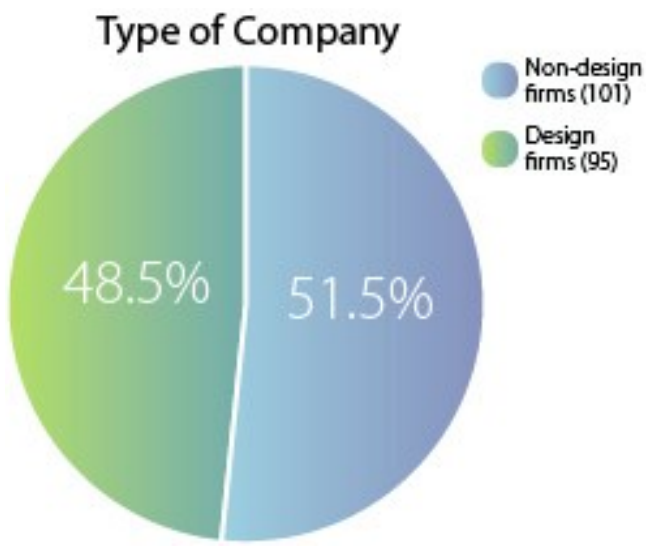

Figure 16. The values of respondents based to type of company.

In terms of position, $10.2 \%$ (twenty) were junior designers, $41.3 \%$ (81) were designers, and $17.9 \%$ (thirty-five) were senior designers. Designer managers and design researchers accounted for $14.3 \%$ (twenty-eight) and 3.1\% (six), respectively. Twenty-six (13\%) held other positions (see Figure 17). Seventy-three (37.2\%) respondents had been working for three to five years. Thirty-four (17.3\%) had one to two years of working experience, and thirty-seven (18.9\%) were at the earlier stages of their careers. Twenty-three (11.7\%) respondents had six to eight years of experience. Twenty-nine respondents had more than eight years of experience (see Figure 18). 


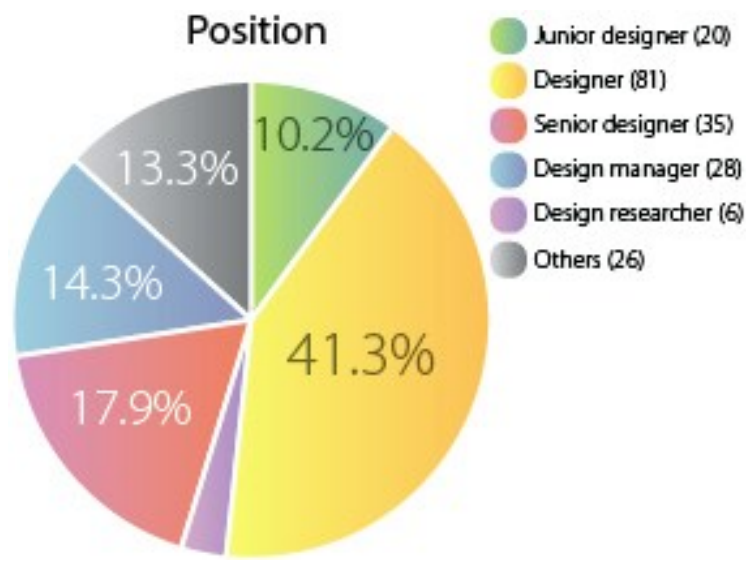

Figure 17. The values of respondents based to position.

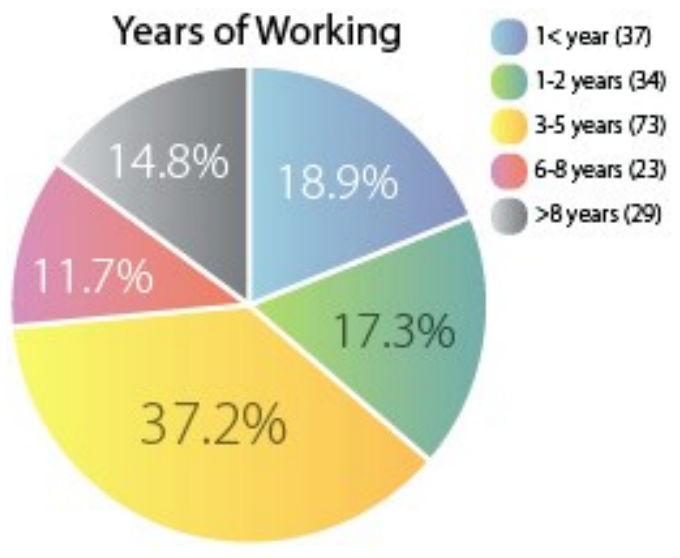

Figure 18. The values of respondents based to years of working.

Additionally, the most influential people for inspiring entrepreneurial intentions in respondents were found to be friends, classmates, and alumni. Sixty-two respondents $(31.6 \%)$ selected this group (see Figure 19). As far as the second most influential group, forty-nine respondents $(25 \%)$ considered their colleagues and other designers to be the source of EI motivation. Clearly, creative individuals tend to be motivated by those around them, such as friends, coworkers, classmates, schoolmates, and alumni. 


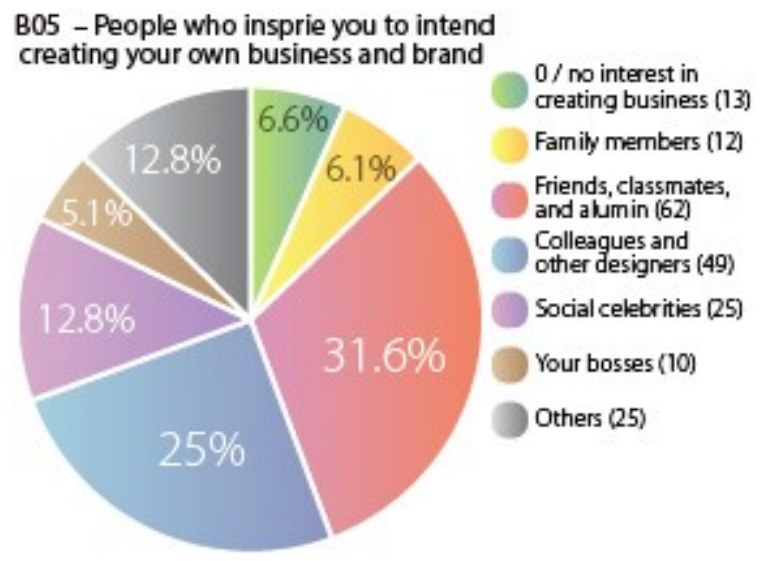

Figure 19. The values of respondents based on the most influential persons.

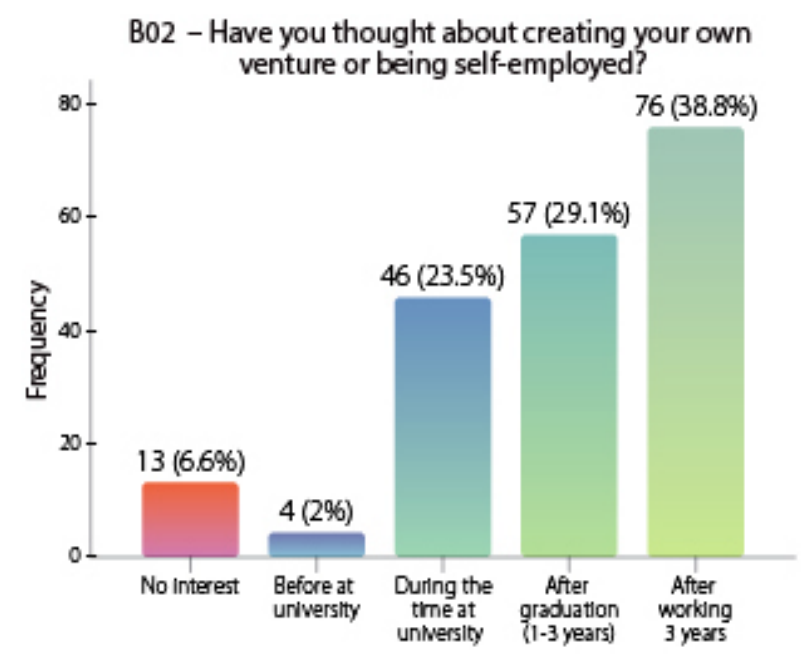

Figure 20. The values of respondents' entrepreneurial aspirations.

Finally, figure 20 shows that $93.4 \%$ of respondents have considered creating their own business. However, only four (2\%) respondents carried their entrepreneurial aspirations at the very early stage, which was before they were enrolled in university. More than forty-six (23.5\%) of them had their entrepreneurial aspirations during their academic journey, and fifty-seven (29.1\%) of them had their entrepreneurial aspirations when they started to gain some working experience. The latter two groups account for more than $50 \%$ of respondents. This supports the findings from the interview data - that Chinese designer's EIs are very positive. Furthermore, the working categories of respondents, such as industrial design, graphic design, interaction design, and web design, are not presented in the frequency distribution analysis. The reason for this is that many respondents' working tasks involve different categories. For example, one respondent works as an industrial designer but this respondent is also a freelance graphic designer. Often a designer needs work on two or three categories at the same time. 
4.2.2 Factor analysis. All the survey questions were coded into upper case alphabetic letters, from A to F (see Appendix 3). For example, A represents the general information section, A01 indicates gender, A02 means age, and so forth. One letter represents a set (i.e., A and B are two different sets). From the perspective of this study, sets C and D (entrepreneurial intentions and motivations and obstacles for entrepreneurship) were examined through a multivariate research approach. All questions from those sets were included as variables in the factor analysis. The researcher performed the Kaiser-Meyer-Olkin (KMO) test. The KMO measure of sampling adequacy tests determine whether the partial correlations among variables are small and determines if the data is not biased (Kajalo, Rajala, \& Westerlund, 2007). Based on the KMO measure and overlapping variables in the rotated factor solution, the researcher dropped out variables that had low communality values $\left(h^{2}<.50\right)$ and those that were loaded into several factors simultaneously. As a result, the factor analysis provided a clean factor load, showing no overlaps with communalities over 0.50 . The following variables were excluded from the final factor solution: C01, C07, C08, C10, D04, D06, D07, D09, D10, D12, and D13. The KMO of this solution was $0.75(p=.000)$, thus exceeding the 0.70 threshold for a good value (Hair et al., 2009). The rotated factor solution provided 8 different factors that explained $65.5 \%$ of the variance (Eigenvalue $>1$, Varimax rotation). These factors describe entrepreneurial drivers as perceived by respondents in the data. The researcher labeled eight factors based on the variables as follows: 1, knowledge; 2, entrepreneurial passion (and confidence); 3, entrepreneurial resources; 4, independency; 5 , ease of start; 6 , difficulty of finding job; 7 , second option; and 8, external support (see Table 2). See Appendix 4 for full results from the analysis. 
Table 2

Factors and factors loading based on variable sets $C$ and $D$

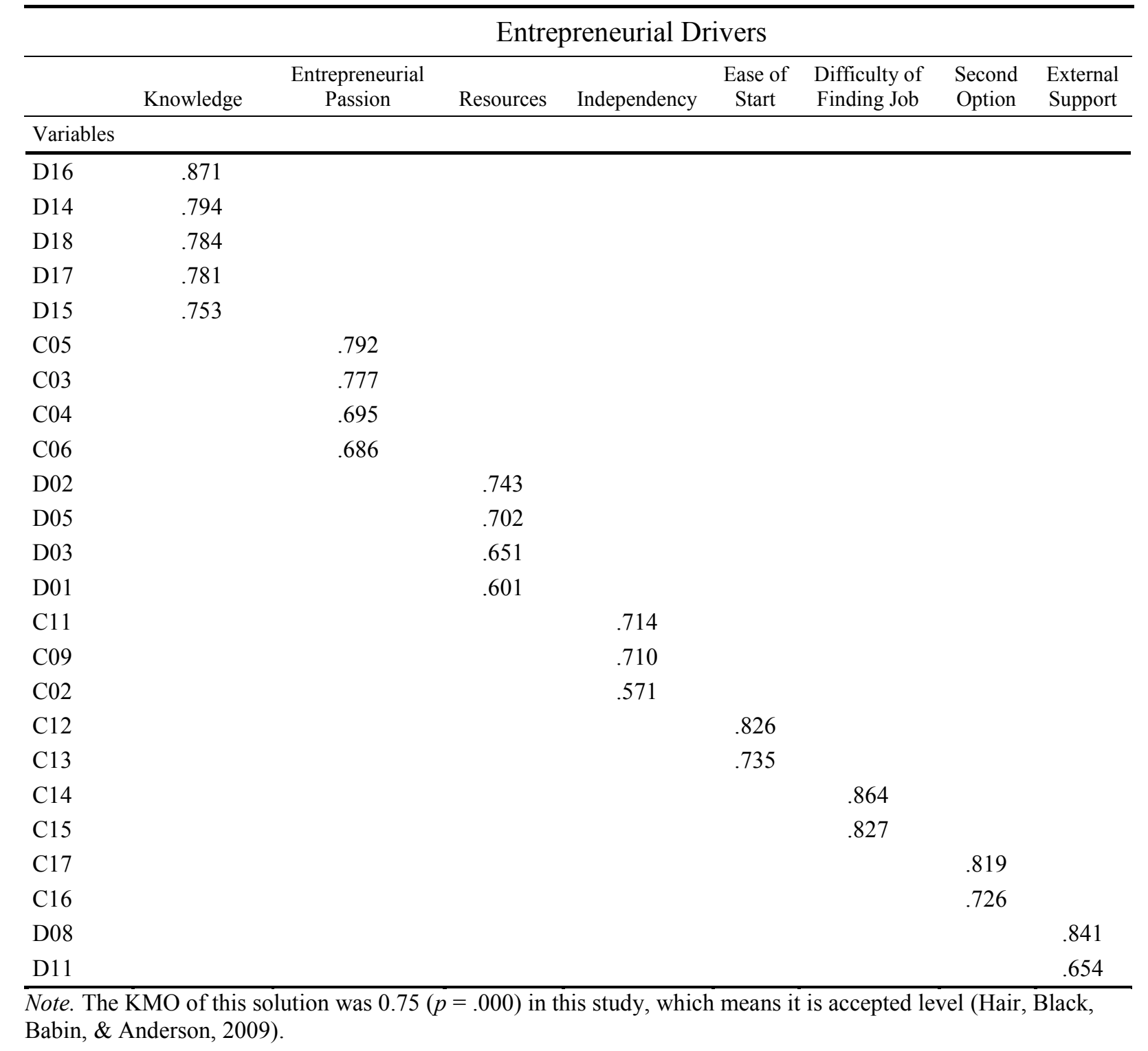

Knowledge (entrepreneurial and business knowledge). Based on the variables in set D, motivations and obstacles for entrepreneurship, variables in terms of D14, D15, D16, D17, and D18 are as follows: D14, the knowledge of economy and business; D15, the knowledge of manufacturing and production; D16, the knowledge of brand development; D17, the knowledge 
of marketing and e-marketing; and D18, entrepreneurship and management. The SPSS software found the comparable patterns from responses to these variables. Thus, the researcher synopsized all these factors as (entrepreneurial) knowledge.

Entrepreneurial passion (egoistic passion). The researcher summed up all factors from these variables and named them entrepreneurial passion because of similar patterns found in variables in terms of $\mathrm{C} 03, \mathrm{C} 04, \mathrm{CO}$, and $\mathrm{C} 06 . \mathrm{C} 03$ is about strong business acumen. $\mathrm{C} 04$ is related to adequate good ideas for generating business. C05 is pertinent to positive entrepreneurial intentions, and C06 is associated with confidence about successful business creation. Based on Bird's (1988) model of EIs, all the factors relate to internal factors, and these factors relate to entrepreneurial motivations in terms of self-efficacy, locus of control, and goal setting (Shane et al., 2003). The researcher considered these four variables as pertaining to personal confidence and enthusiasm. Thus, entrepreneurial passion was labeled as the factor description.

Entrepreneurial resources (availability). Four variables were grouped by the SPSS software: D01, a great idea; D02, a business model; D03, personal perseverance and confidence; and D05, time. Descriptions form these variables seem different. The SPSS software suggests patterns from these four variables are similar at some levels. According to Bird's (1988) model of EIs, D01 and D03 are considered as internal factors, and D02 and D05 belonging to external factors. The researcher decided to use resources as a neutral description for this factor because resources include the needs and necessities for entrepreneurship. Availability would be an alternative term for summing up these four aspects.

Independency. The researcher utilized independency as a factor description for variables $\mathrm{C} 02, \mathrm{C} 09$, and $\mathrm{C} 11$ because items in these variables are self-working, freedom, and personal 
interest. Self-working and freedom related to the suggestion of Shane et al. (2003) that independence is one of the motivated drivers.

Ease of start. Based on the variables in terms of $\mathrm{C} 12$ and $\mathrm{C} 13$ from the set $\mathrm{C}$, entrepreneurial intentions, and the SPSS software suggests these two variables have similar patterns, the researcher decided to use ease of start as the description for this factor. Thus, variable $\mathrm{C} 12$ and $\mathrm{C} 13$ are both referring to developing a brand and creating a business would be an easier task for designers.

Difficulty of finding job (social pressure). Based on the SPSS software findings, the researcher used difficulty of finding job as the description to sum up variables $\mathrm{C} 14$ and $\mathrm{C} 15$ because these two variables collected responses based on the difficulties of job applications for design graduates.

Second option (passivity). Variables C16 and C17 were grouped by the SPSS software. Based on the statements of these two variables, entrepreneurship was not the priority option for respondents. Thus, the researcher labeled these two variables as second option.

External support. As the last factor, variables D08 and D11 were both pertinent to external factors. They are team (support) and governmental policies. According to the model of EIs (Bird, 1988), these two items are external factors. Thus, external support was used as the description for these two variables by the researcher.

4.2.3 Cluster analysis. After identifying the entrepreneurial drivers through the factor analysis, these variables were subjected to K-means cluster analysis. The purpose of cluster analysis was to identify the different types of designers in terms of their attitudes toward entrepreneurship. The result of clustering was a five-group solution that can be logically interpreted. The one-way analysis of variance (ANOVA) results indicate that the eight factors, 
knowledge $(F=39.489, \mathrm{df}=191, p=.000)$, entrepreneurial passion $(F=8.153, \mathrm{df}=191, p$ $=.000)$, entrepreneurial resources $(F=9.135, \mathrm{df}=191, p=.000)$, independency $(F=25.945, \mathrm{df}$ $=191, p=.000)$, ease of $\operatorname{start}(F=8.959, \mathrm{df}=191, p=.000)$, difficulty of finding job $(F=$ $18.319, \mathrm{df}=191, p=.000)$, second option $(F=27.622, \mathrm{df}=191, p=.000)$, and external support $(F=12.104, \mathrm{df}=191, p=.000)$, were significant contributors to the cluster solution. This solution provided a balanced spread between the number of respondents in different clusters ( 53 , $55,40,18$, and 30 per cluster). The final clusters are presented in Table 3 . The clusters were labeled based on the most contributing factors to the solution (bolded values). The five clusters are as follows: 1, I'm not entrepreneur (53); 2, I have no options (55); 3, I want a side business (40); 4, It's all about good ideas (18); and 5, Business knowledge matters (30). See Appendix 5 for full results from the analysis.

Table 3

Five types of designers based on their entrepreneurial intentions

\begin{tabular}{|c|c|c|c|c|c|}
\hline & \multicolumn{5}{|c|}{ Potential Entrepreneurial Clusters } \\
\hline & $\begin{array}{c}1-\text { I'm not } \\
\text { entrepreneur } \\
\quad(n=53)\end{array}$ & $\begin{array}{c}2 \text { - I have no } \\
\text { options } \\
(\mathrm{n}=55)\end{array}$ & $\begin{array}{c}3 \text { - I want a } \\
\text { side business } \\
\quad(\mathrm{n}=40)\end{array}$ & $\begin{array}{c}4 \text { - It's all } \\
\text { about good } \\
\text { ideas }(n=18)\end{array}$ & $\begin{array}{c}5-\text { Business } \\
\text { knowledge } \\
\text { matters } \\
(\mathrm{n}=30)\end{array}$ \\
\hline \multicolumn{6}{|l|}{ Entrepreneurial Drivers } \\
\hline Knowledge & .45081 & -.33396 & .27692 & -1.81963 & .53838 \\
\hline Entrepreneurial Passion & -.54057 & -.08331 & .37475 & .40507 & .36505 \\
\hline Entrepreneurial Resources & .20140 & -.41230 & -.16953 & 1.01812 & .01525 \\
\hline Independency & .45462 & -.87926 & .52299 & .44253 & -.15402 \\
\hline Ease of Start & .46938 & .02744 & -.04175 & -.04755 & -.79534 \\
\hline Difficulty of Finding Job & .23053 & .53614 & -.93038 & .02380 & -.16397 \\
\hline Second Options & -.41421 & .46769 & .71999 & -.16806 & -.98481 \\
\hline External Support & .52857 & -.05550 & -.00740 & .12567 & -.89759 \\
\hline
\end{tabular}


The characteristics of these five clusters are discussed in more detail below:

Cluster 1: I'm not entrepreneur. The respondents in cluster 1 value the importance of external support (i.e., supportive teams and government policies), the ease of start-up, the feeling of independency from others, and the knowledge of relevant issues (i.e., business, production, brands, marketing, and entrepreneurial management) as the drivers that support becoming entrepreneurs. Conversely, the negative loading of entrepreneurial passion reflects that these respondents lack confidence, business acumen, and ideas required for entrepreneurship. In sum, these respondents understand what entrepreneurship means to them, but they are unwilling to become entrepreneurs unless they acquire some facilitators or encouragement.

Cluster 2: I have no options. The respondents in cluster 2 do not value independency from the others as a key driver for entrepreneurship. Moreover, they perceive that entrepreneurial resources (in terms of the idea, business model, personal confidence, and time) are not key motivators for them to become entrepreneurs. Conversely, they think that the difficulty of finding a job would drive them to become entrepreneurs. They have also thought about other options, such as postgraduate studies, in case they do not get employed as designers after graduation. In sum, these respondents would opt for entrepreneurship as a result of not being employed elsewhere.

Cluster 3: I want a side business. The respondents in cluster 3 are not driven by the difficulties of finding job. Rather, they would opt for entrepreneurship in order to find something meaningful to do if they failed to be employed after graduation or for the sake of gaining independency from others. They are probably already employed, or they feel quite confident about employment, but they are likely to consider entrepreneurship as an option for having a side business. 
Cluster 4: It's all about good idea. This is the smallest group and includes respondents, who perceive that knowledge of doing business in general is not the integral component for becoming an entrepreneur. Rather, these respondents emphasize the importance of entrepreneurial resources (especially business models and ideas), entrepreneurial passion. They are motivated by becoming independent from the others. The respondents in cluster 4 think that becoming an entrepreneur is all about having a good business idea. The lack of good ideas would likely prevent them from perusing entrepreneurship.

Cluster 5: Business knowledge matters. The respondents in cluster 5 observe that entrepreneurship does not depend on the lack of employment after graduation, the lack of support from others or the government, or the ease of starting up a business. Rather, they think the most important driver for becoming an entrepreneur is having generic business knowledge and skills, such as marketing and management skills. In sum, these respondents are not afraid of the lack of support from the environment; instead, they are concerned about their lack of business knowledge and skills.

4.2.4 Crosstabs analysis. After the factor analysis and cluster analysis, results from crosstabs tests were presented to discover if there were significant correlations between selected variables and/or groups (e.g., clusters). The results are significant if the Pearson Chi-square is $<.05$, suggesting that there is a statistically significant relationship between the selected variables. For this analysis, instead of using short codes, descriptive labels were used for the variables in order to make results easier to interpret. Only significant and reasonable results are reported and discussed in the following section and included in Appendix 6.

The crosstabs of type of school and gender $(A 03 * A 01)$. In the cross-tabulation of type of school and gender (Pearson's Chi-square $=.023$ ), it seems that the number of females 
respondents that graduated from top design schools (tier one) was slightly higher than the number of male respondents who graduated from tier one schools. However, the total percentage rate of male respondents was larger than female respondents. Thus, the per capita percentage of female respondents who graduated from top design schools is essentially higher. One out of two female respondents graduated from national level design schools (see Figure 21). The majority of male respondents have degrees conferred by regular level design schools. This means that, although the quantity of the female designers is still smaller than the number of males, the propensity is that there will be more female designers graduating from better design schools in China.

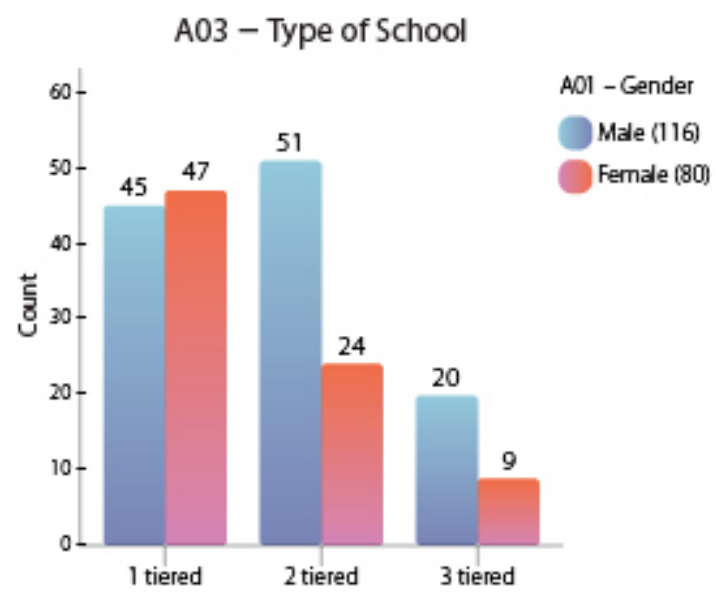

Figure 21. The crosstabs of type of school and gender $(\mathrm{A} 03 * \mathrm{~A} 01)$.

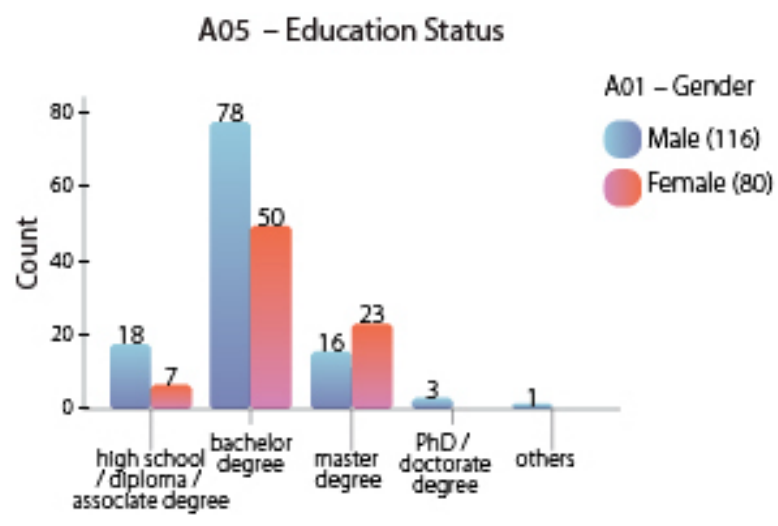

Figure 22. The crosstabs of education status and gender $(\mathrm{A} 05 * \mathrm{~A} 01)$.

The crosstabs of education status and gender $(A 05 * A 01)$. Results from the crosstabulation of education status and gender demonstrate that, in both female and male groups, the number of respondents who hold bachelor's degrees is extremely higher than the amount of 
respondents holding diplomas, master's degrees, or a doctorate degrees (Pearson's Chi-square $=.041)$. In addition, females have a higher level of educational status compared to males because the number of female respondents who have a master degrees is significantly higher than males (see Figure 22).

The crosstabs of education status and the final question $(A 05 * F)$. Results from the cross-tabulation of education status and the final question, if you had an opportunity to experience entrepreneurial courses, which courses do you think you would prefer to, demonstrate that the option of a design-business-mixed entrepreneurial program is enormously favorable to most of the respondents because there were one hundred and twenty-third respondents $(62.8 \%)$ selected it, and there were eighty-eight respondents (71.5\%) who have a bachelor degree selected this option (Pearson's Chi-square $=.000$ ). In Figure 23, the second favorable option is internettechnological-oriented entrepreneurial programs; 35 (17.9\%) respondents selected this option over the other two options, design-oriented (21/10.7\%) and business-oriented (17/8.7\%).

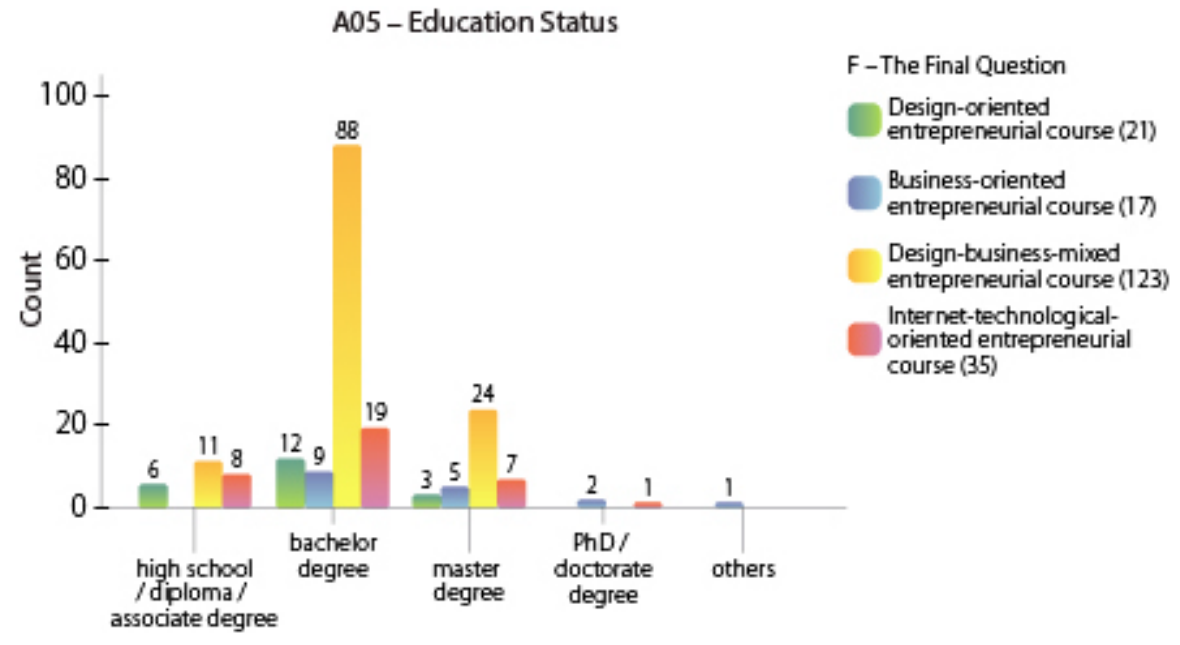

Figure 23. The crosstabs of education status and the final question (A05* F). 


\section{From variable set $B *$ to set $A$.}

The crosstabs of entrepreneurship and gender $(\mathrm{B01} * \mathrm{A01})$. The cross-tabulation of entrepreneurship and gender is demonstrated in Figure 24. It shows that males are more entrepreneurial than females (Pearson's Chi-square $=.008$ ). One out of four male respondents were running their own business; whereas, merely one out of ten females were running their own business. This signifies that entrepreneurship in design is still dominated by male designers.

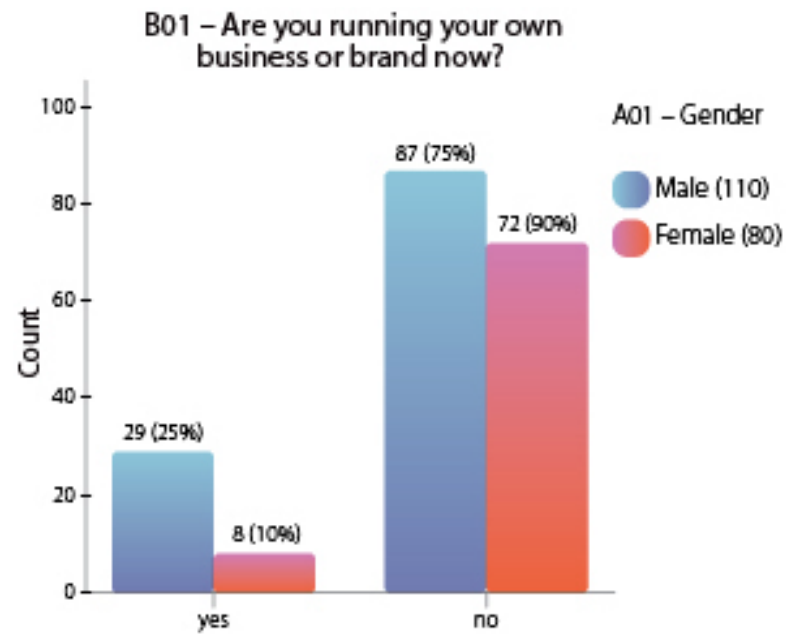

Figure 24. The crosstabs of entrepreneurship and gender $(\mathrm{B} 01 * \mathrm{~A} 01)$.

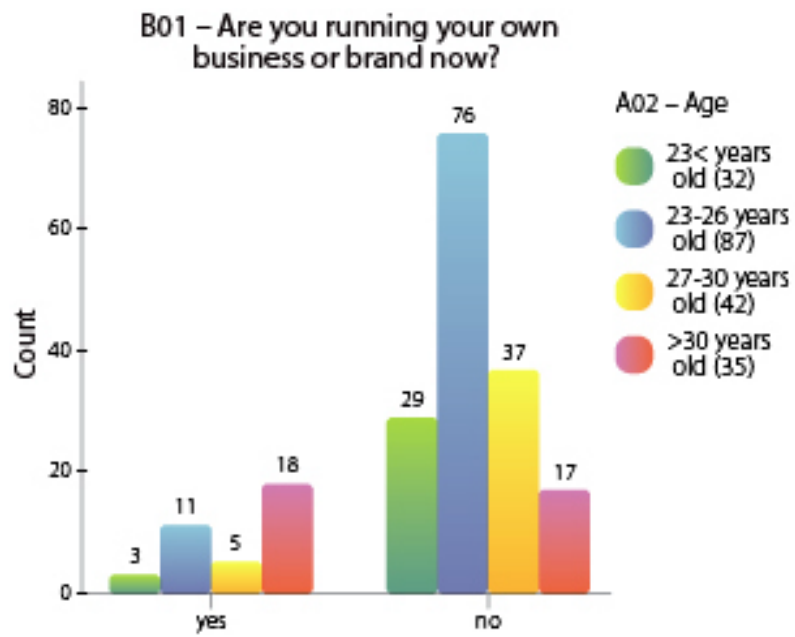

Figure 25. The crosstabs of entrepreneurship and age $(\mathrm{B} 01 * \mathrm{~A} 02)$.

The crosstabs of entrepreneurship and age $(\mathrm{B01} * \mathrm{A02})$. Results from the crosstabulation of entrepreneurship and age narrate that, although the percentage of existing entrepreneurship in group 1, the youngest respondents (green bars), is six times smaller than in group 4, the eldest respondents (red bars), the existing entrepreneurship among young respondents is still recognizable. This is because the percentage of existing entrepreneurship in the group 1 ( $23<$ years old) and group 2 (23-26 years old) together is $37.8 \%$. This means three 
out of eight youths are running their own business. The total rate of existing entrepreneurship is close to $19 \%$ (37 respondents), which means almost one in five respondents were running their own business. This also means the percentage of existing entrepreneurship among all respondents is relatively high (see Figure 25).

The crosstabs of entrepreneurship and type of school $(B 01 * A 03)$. In the crosstabulation of entrepreneurship and type of school (Pearson's Chi-square $=.041$ ), results represent that respondents who graduated from regular college-level design schools (tire two) have the highest percentage of entrepreneurship; almost one out of three respondents in this category was found to be running their own business. In contrast, respondents holding degrees conferred by national-level design institutions (tier one) has the lowest rate of entrepreneurship; close to one out of eight respondents in this category were running their own business (see Figure 26). This shows that creative individuals that graduate from top design schools have a low level of EIs. The reason would be that design students who graduated from tier one design schools could easily apply for better jobs than students who graduate from tier two and tier three design schools. Thus, the unemployed risk increases EIs in students who graduate from low tier design schools. 


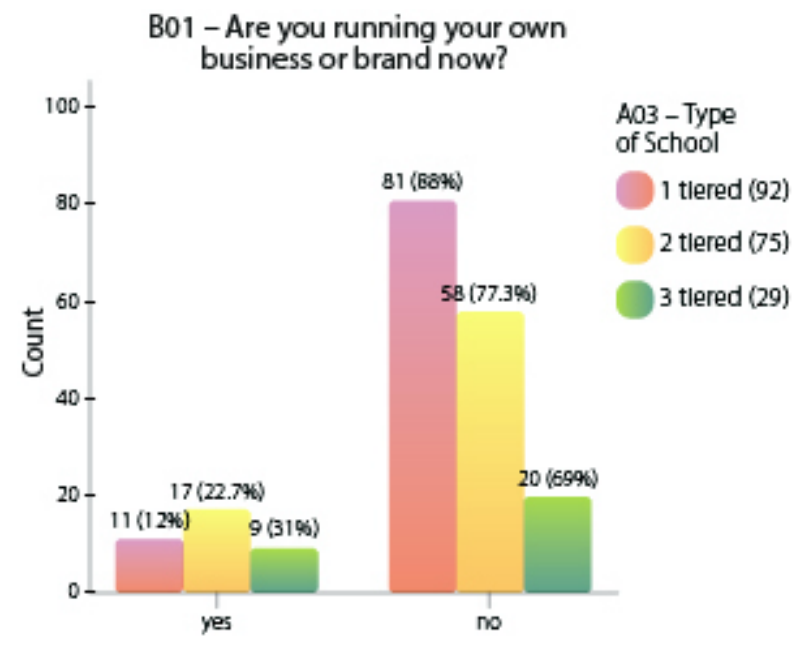

Figure 26. The crosstabs of entrepreneurship and type of school (B01*A03).

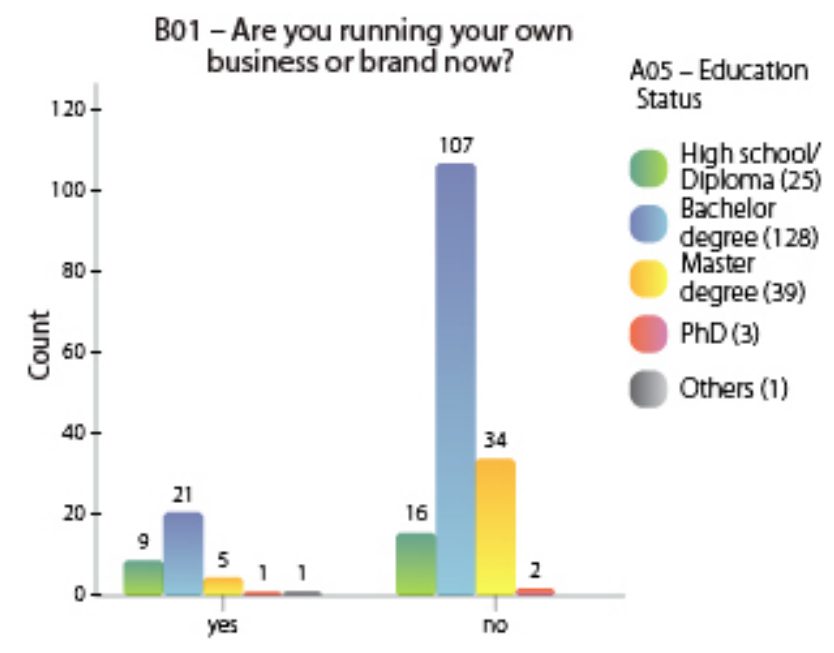

Figure 27. The crosstabs of entrepreneurship and education status (B01* A05).

The crosstabs of entrepreneurship and education status $(B 01 * A 05)$. Results in the cross-tabulation of entrepreneurship and education status show that those with lower education status has higher the percentages of entrepreneurship (Pearson's Chi-square $=.027$ ). One out of three respondents that holds diploma is running a business, and only one out of six respondents who held bachelor's degrees were operating a business (see Figure 27-13.3). This means that creative individuals who hold diplomas have higher entrepreneurial aspirations and motivations.

The crosstabs of entrepreneurship and type of company $(B 01 * A 06)$. In the crosstabulation of entrepreneurship and type of company (Pearson's Chi-square $=.000$ ), results demonstrate that opening design consulting companies is favorable to respondents. Thirty-one $(83.8 \%)$ respondents were running design firms and only to six $(16.2 \%)$ respondents were running non-design companies. This demonstrates that developing a design-consulting company is the first option for designers who intend to start their own business in China (see Figure 28). 


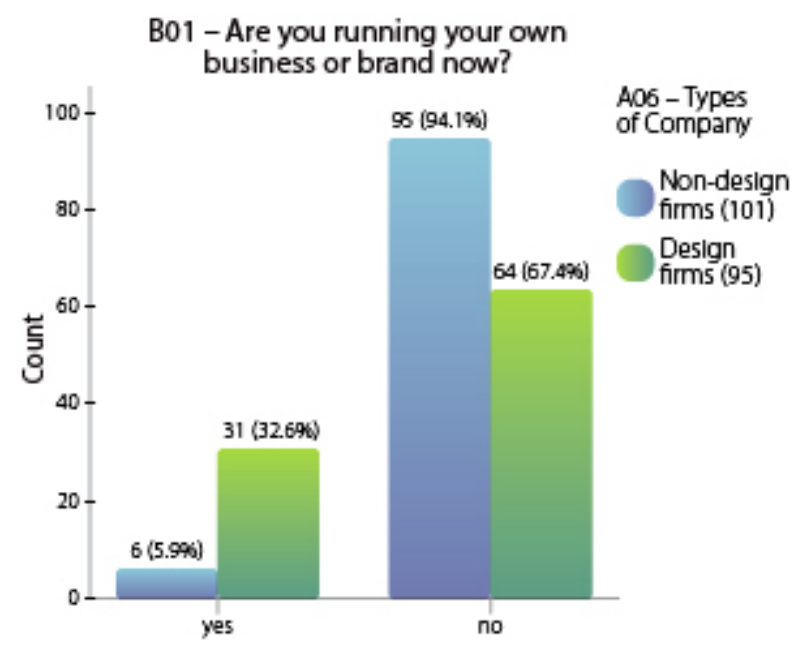

Figure 28. The crosstabs of entrepreneurship and type of company (B01* A06).

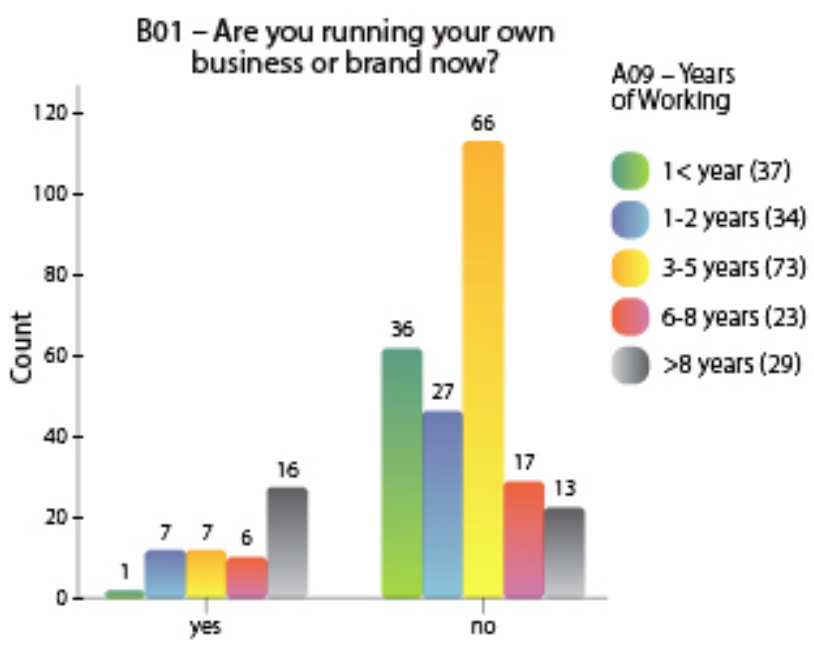

Figure 29. The crosstabs of entrepreneurship and years of working $(\mathrm{B} 01 * \mathrm{~A} 09)$.

The crosstabs of entrepreneurship and years of working (B01*A09). Results from the cross-tabulation of entrepreneurship and years of working illustrate that $16(43.2 \%)$ respondents who had more than eight years of working experience are business owners (Pearson's Chi-square $=.000)$. Thirty-seven point eight percent respondents who have one to three years of experience were running their business. Only one respondent who had less than one year of experience was a business owner (see Figure 29-13.5). This signifies that most of the respondents start to develop their businesses when they have already had some experience.

The crosstabs of start-up categories and gender $(B 03 * A 01)$. The cross-tabulation of the most appealing category to start a business and gender shows that two out of three respondents wanting to start a business related to media and photography were female. This is significantly different from the other groups, which were mostly male dominated (Pearson's Chi-square $=.044)$. Conversely, $80 \%$ of respondents (25) interested in IT products were male. This 
overemphasized male-dominance within the group is significant because $60 \%$ of the respondents (110) in the data were male. Given the overall gender spread of the data $(60 \%$ men, $40 \%$

women), the $50 / 50 \%$ result in the category of crafts and products means that in addition to media and photography, entrepreneurship in crafts and products appeals to more women than men (see Figure 30).

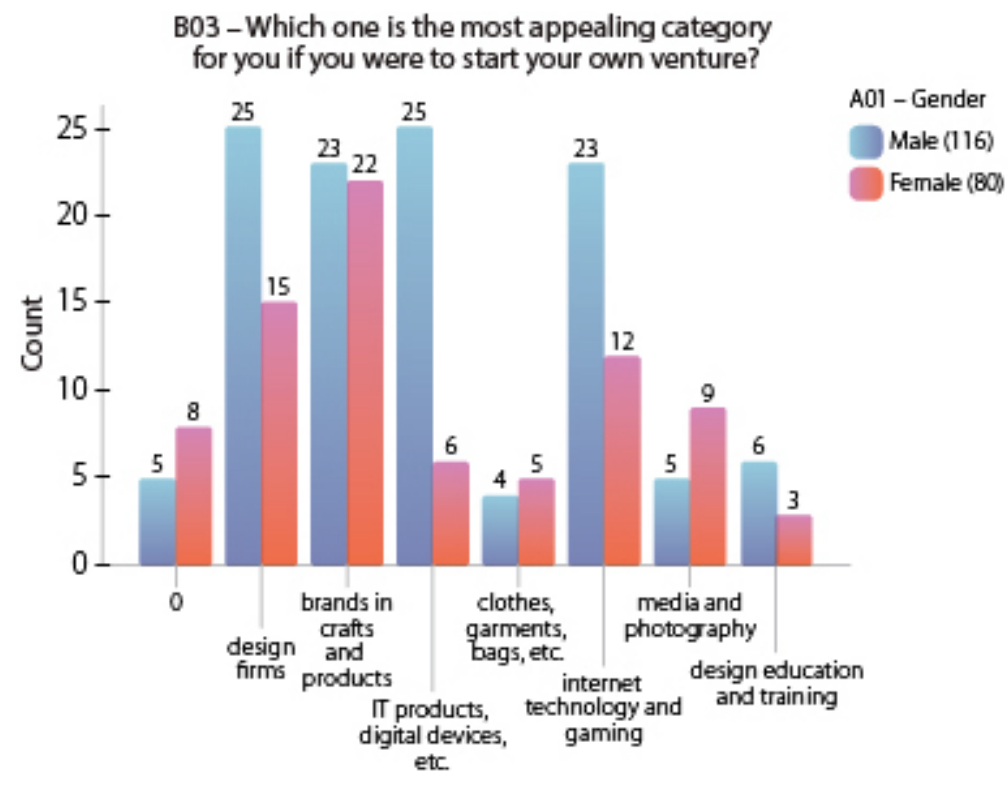

Figure 30. The crosstabs of start-up categories and gender (B03* A01).

The crosstabs of the likelihood of creating venture and age $(B 04 * A 02)$. Results from the cross-tabulation of the likelihood of venture creation and age demonstrates that the more experience respondents have and as they become older, the more likely they are to create businesses (Pearson's Chi-square $=.001)$. The likelihood of starting a business in the youngest group was very low; only one respondent (4\%) intended to create their venture within one to two years, and fourteen $(52 \%)$ intend to create their venture within five years. In contrast, six (40\%) 
respondents in group 4 (the eldest group) intend to create their own business in one to two years (see Chart 31). Most of the respondents considered creating their business in three to five years, or even later, from the time of the survey.

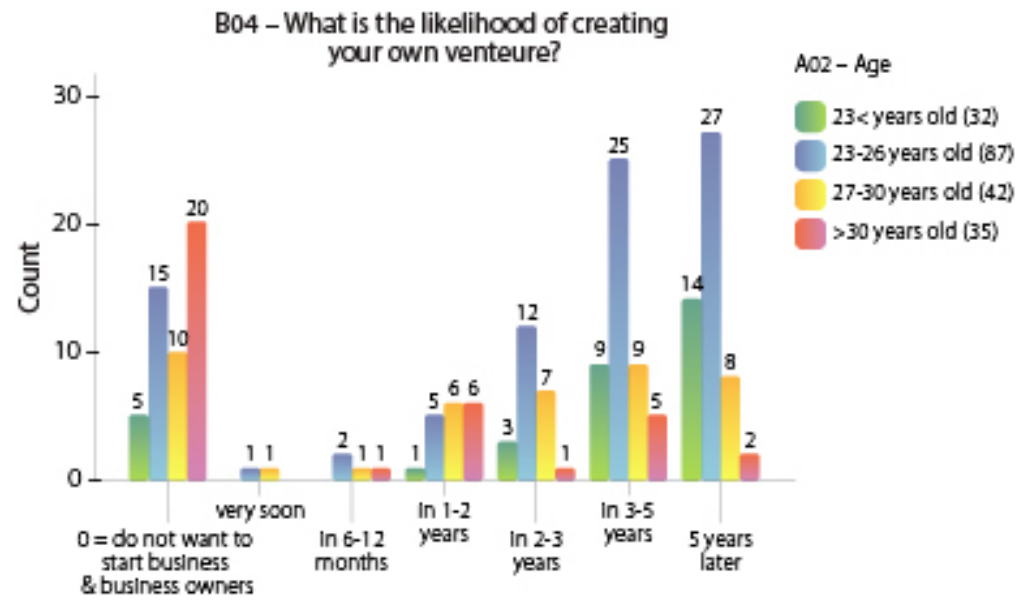

Figure 31. The crosstabs of the likelihood of creating venture and age (B04* A02).

The crosstabs of the likelihood of crating venture and type of company (B04*A06).

The cross-tabulation of the likelihood of venture creation and type of company shows that respondents who work for non-design companies intend to start creating their business sooner than respondents who work for design firms (Pearson's Chi-square $=.001)$. Additionally, respondents who work for non-design companies have a higher intention of entrepreneurship compared to those who work for design firms (see Chart 32). 


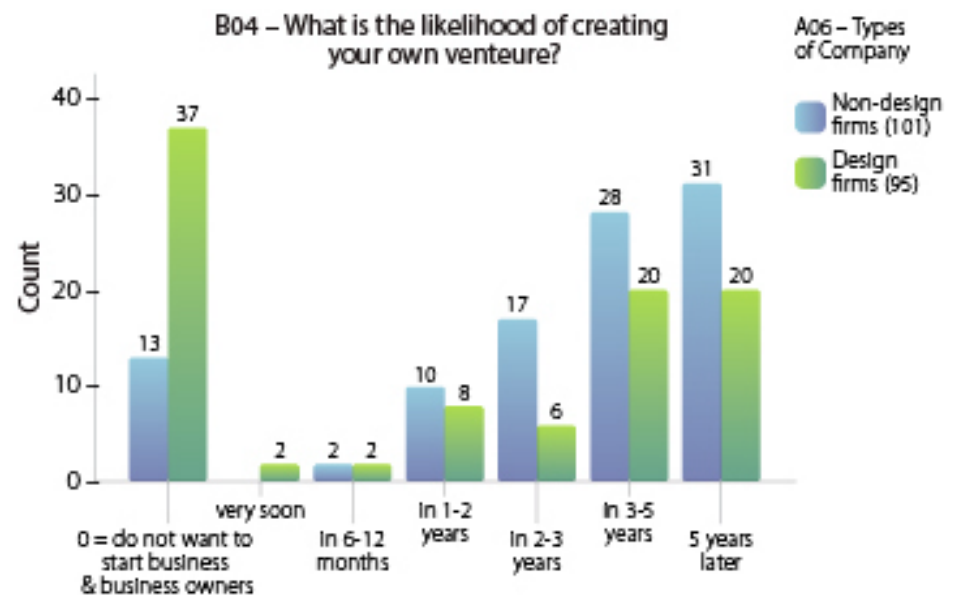

Figure 32. The crosstabs of the likelihood of creating venture and type of company (B04* A06).

The crosstabs of the likelihood of creating venture and years of working $(B 04 * A 09)$.

Results from the cross-tabulation of the likelihood of venture creation and years of working suggest that respondents who have three to five years of experience have a higher likelihood of developing their own business (Pearson's Chi-square $=.000$ ). Meanwhile, respondents who have very little working experience intend to create their own business much later than (see Figure 33). Conversely, in group 5, the most experienced group, eighteen (62.1\%) respondents decided they do not want to create their own business. 


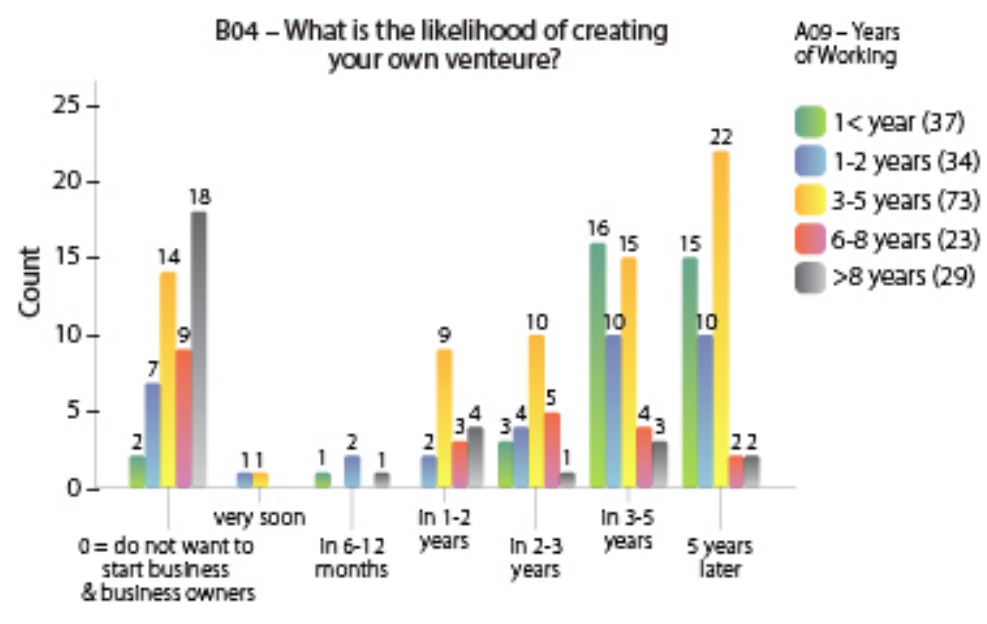

Figure 33. The crosstabs of the likelihood of creating venture and years of working (B04* A09).

The crosstabs of the likelihood of creating venture and clusters (B04*Clusters). The

likelihood of creating one's own venture seems to differ between the five clusters (Pearson's Chi-square $=.011)$. The likelihood of starting a business soon in groups 1 (green bars) and 2 (blue bars) is significantly lower than in groups 3 (yellow bars), 4 (red bars), and 5 (black bars) (see Figure 34). Respondents in groups 1 and 2 are likely to start their business after three to five years or longer, whereas respondents in groups 3, 4 and 5 are likely to start a business within one to three years. In the category of those who did not want to start any business, the numbers of group 1 and the group 2 were significantly higher than those in groups 3 , 4, and 5 . This means EIs in groups 3 and 4 are higher than in other groups. 


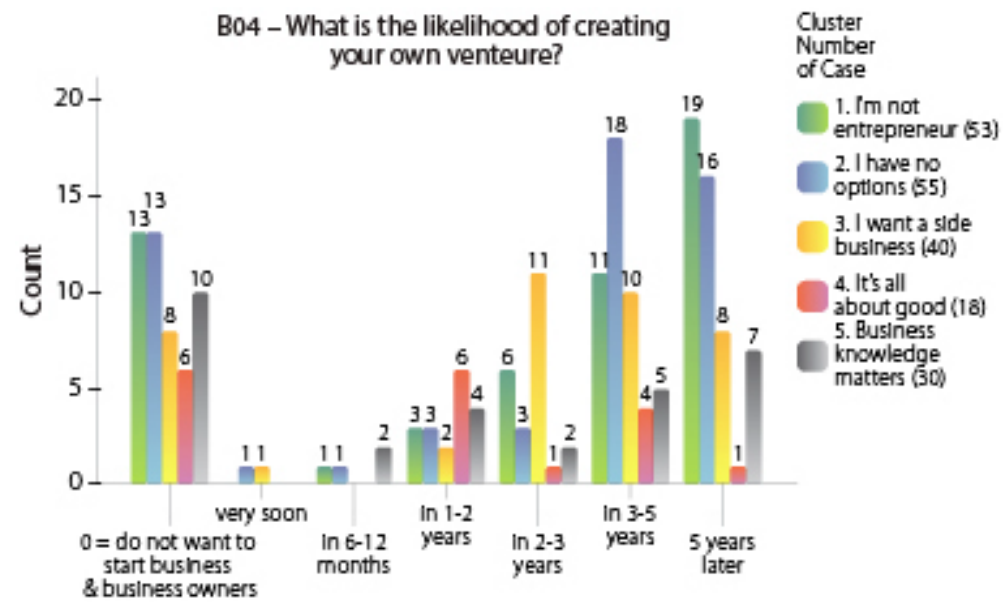

Figure 34. The crosstabs of the likelihood of creating venture and clusters (B04* Clusters).

\section{From variable set $E *$ to set $A$.}

The crosstabs of the obsolete design courses and gender $(E 01 * A 01)$. Results from the cross-tabulation of the obsolete design courses and gender present that male respondents agrees that design courses in schools are obsolete (Pearson's Chi-square $=.045)$. In contrast, the confirmation that design courses in schools are obsolete was vague in female respondents. For example, thirty-two $(27.6 \%)$ males were in the category of slightly agree in contrast to only twenty females (25\%). Additionally, and twenty-nine (25\%) males were in the category of agree, versus on thirteen $(16.3 \%)$ females with the same opinion. Oppositely, female respondents consider design courses in schools to still be relevant; for example, twenty-two $(27.5 \%)$ females are in the category of slightly disagree, while only thirteen $(11.2 \%)$ males indicated the same thing. Furthermore, eight (10\%) females and nine (7.8\%) males were in the category of disagree (see Figure 35). 


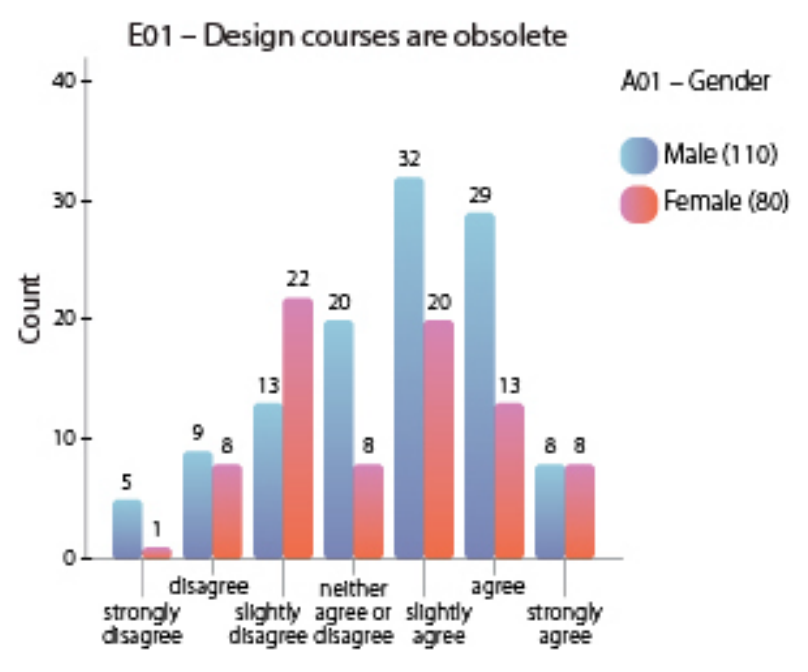

Figure 35. The crosstabs of the obsolete design courses and gender $(\mathrm{E} 01 * \mathrm{~A} 01)$.

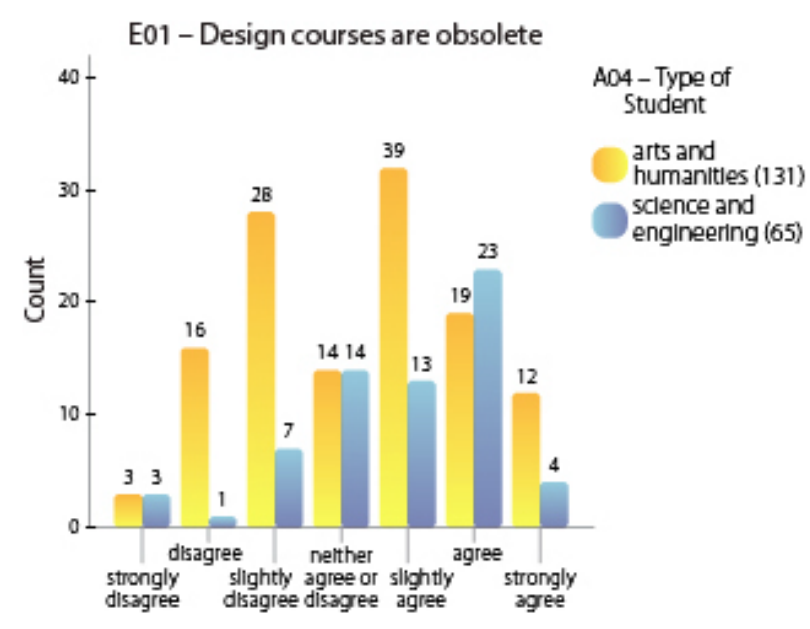

Figure 36. The crosstabs of the obsolete design courses and type of student (E01* A04).

The crosstabs of the obsolete design courses and type of student (E01*A04). Based on the results of the cross-tabulation of the obsolete design courses and type of student (see Figure 36), it was found that all respondents in both categories, arts and humanities and science and engineering, supported the statement that design courses in schools are obsolete (Pearson's Chisquare $=.001)$. However, due to the ratio of types of student in the data $(67 \%$ arts and humanities versus 33\% science and engineering), it can be interpreted that twenty-three respondents whose academic background are science and engineering (35.4\%) is considerably higher than the nineteen arts and humanities students with the same opinion (14.5\%).

The crosstabs of the yearning for more skills and knowledge about design methods and education status (E05*A05). The cross-tabulation of the yearning for more skills and knowledge about design methods and education status presents that respondents with lower 
educational statuses tend agreed more with the statement "I need to learn more about design methods" (Pearson's Chi-square $=.001)$. Moreover, respondents at the master's level also support the statement, but less agreed with it compared to respondents at the bachelor and diploma level (see Figure 37).

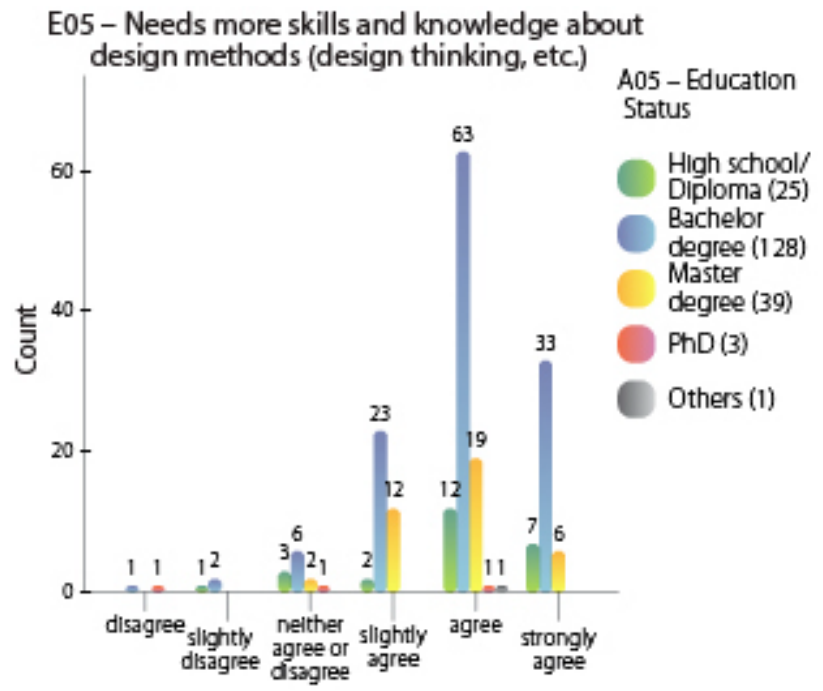

Figure 37. The crosstabs of the yearning for design methods and education status (E05* A05).

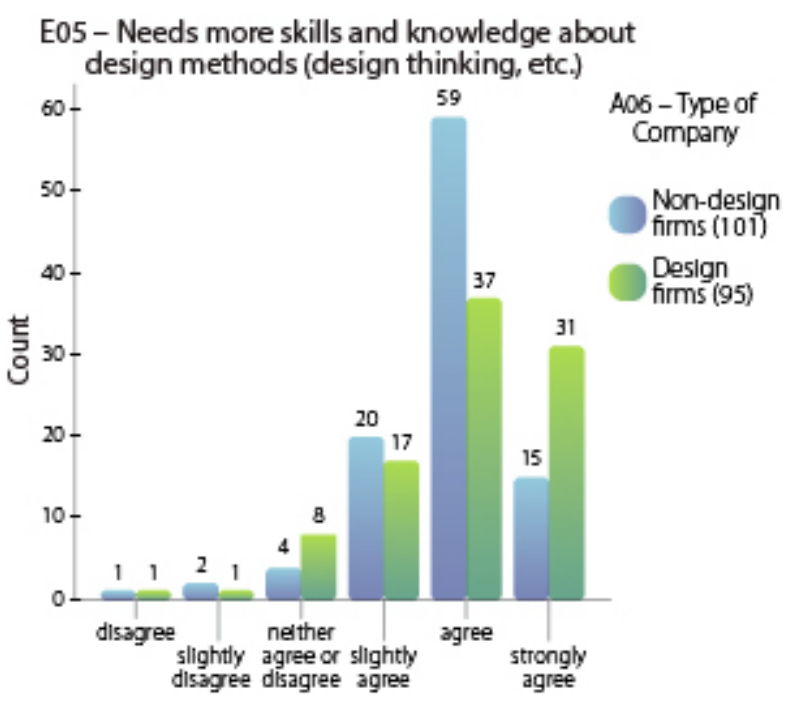

Figure 38. The crosstabs of the yearning for design methods and type of company (E05* A06).

The crosstabs of the yearning for more skills and knowledge about design methods and type of company $(\mathrm{E} 05 *$ A06). Results from the cross-tabulation of the yearning for more skills and knowledge about design methods and type of company demonstrates that respondents who work for non-design companies did not agree with the statement as much as respondents who work for design firms (Pearson's Chi-square $=.030)$. At the scale level of strongly agree, the 
number of respondents who work for design firms was over twice higher than the number for respondents who work for non-design firms (see Figure 38).

The crosstabs of the yearning for more skills and knowledge about software practice and education status $(E 06 *$ A05). The cross-tabulation of yearning for more skills and knowledge about software practice and education status shows that respondents at the diploma, bachelor's, and master's levels all recognized the need for more practices in software programs (Pearson's Chi-square $=.000)$. In contrast, respondents who have a Ph.D. degreed with the statement (see Figure 39). This means software skills and practices are still significant to the majority of designers in China.

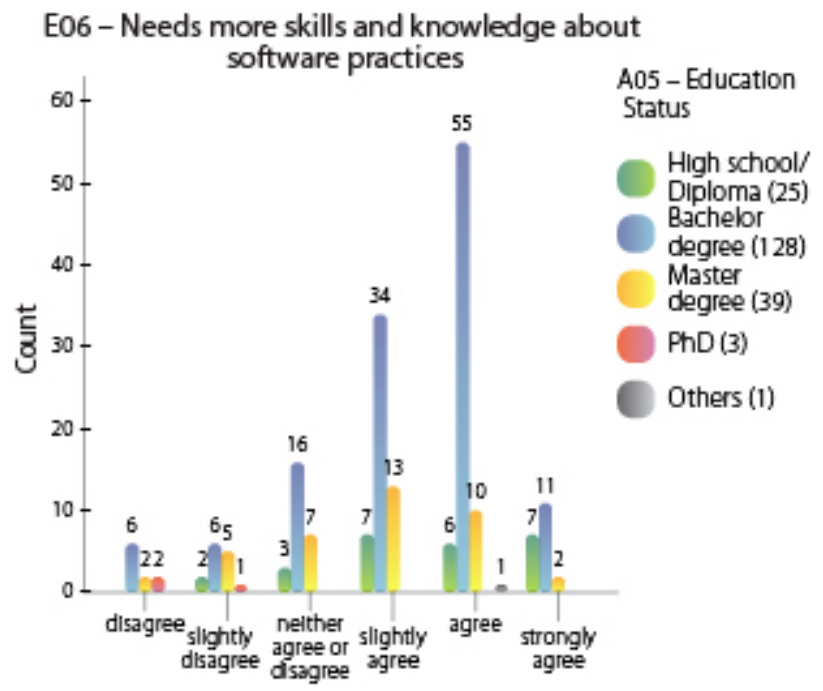

Figure 39. The crosstabs of the yearning for skills and knowledge about software practice and education status (E06* A05).

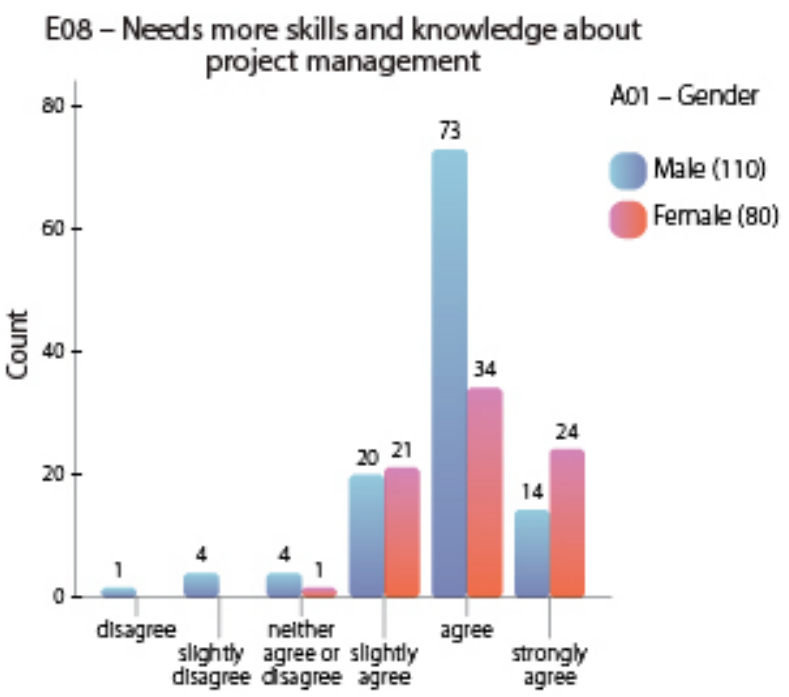

Figure 40. The crosstabs of the yearning for skills and knowledge about project management and gender (E08* A01). 


\section{The crosstabs of the yearning for more skills and knowledge about project}

management and gender $(\boldsymbol{E} 08 * A 01)$. The cross-tabulation of the yearning for more skills and knowledge about project management and gender shows that both female and male respondents unarguably support the statement; they yearn for more knowledge and skills of project management (Pearson's Chi-square $=.003)$. However, there is a slight difference at the scale level of agree and strongly agree. More males than females tended to agree, while females tended to strongly agree more than males (see Figure 40).

The crosstabs of the yearning for more skills and knowledge about project management and education status (E08*A05). Results from the cross-tabulation of the yearning for more skills and knowledge about project management and education status demonstrates that respondents with all levels of academic background supported the statement (Pearson's Chi-square $=.024)$. This finding suggests that skills and knowledge about project management are crucial to design education in China at different levels (see Figure 41). 


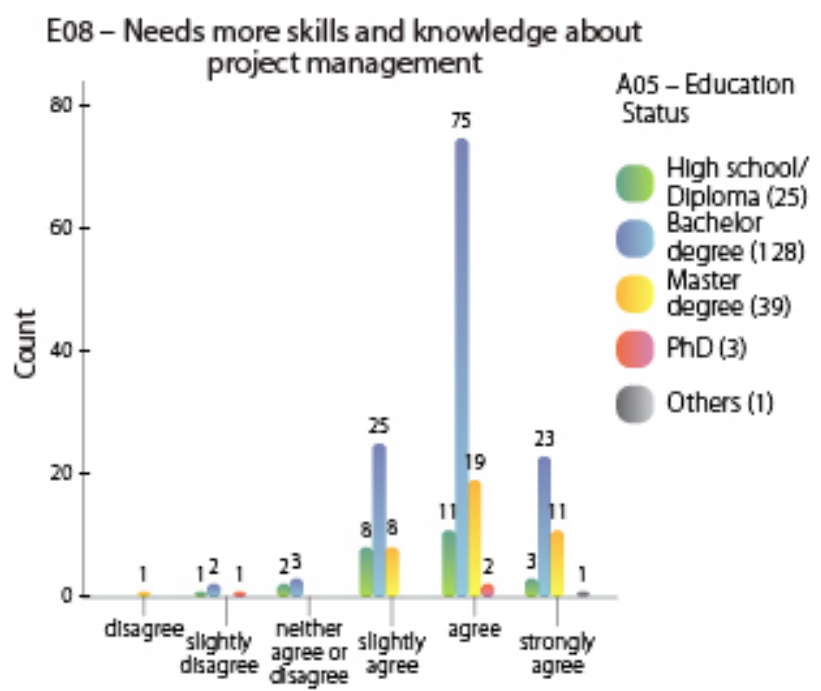

Figure 41. The crosstabs of the yearning for skills and knowledge about project management and education status $(\mathrm{E} 08 *$

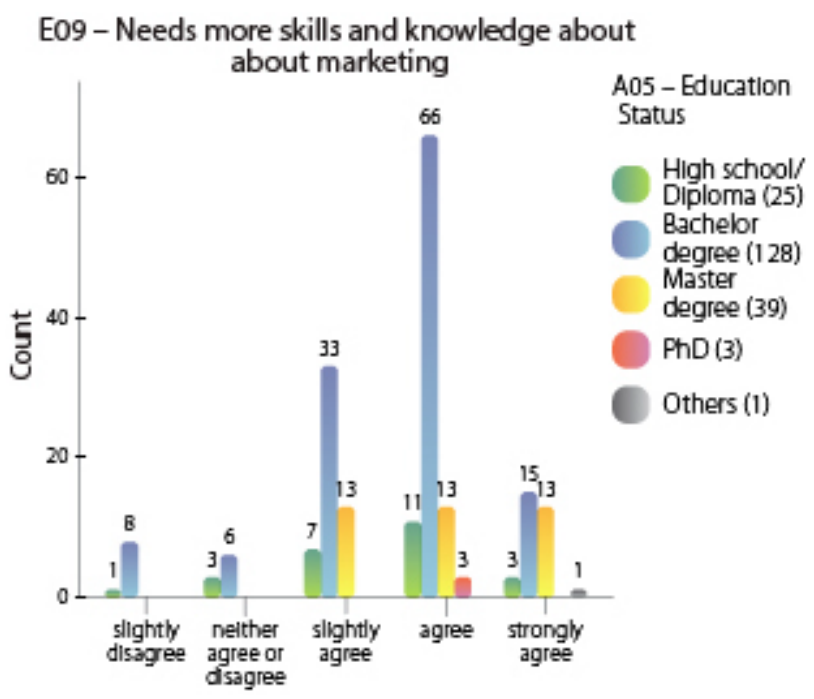

Figure 42. The crosstabs of the yearning for skills and knowledge about marketing and education status $(\mathrm{E} 09 *$ A05). A05).

The crosstabs of the yearning for more skills and knowledge about marketing and education status (E09*A05). The cross-tabulation of the yearning for more skills and knowledge about marketing and education status shows that respondents with all academic background levels agree with the statement (Pearson's Chi-square $=.036$ ). This result suggests that skills and knowledge about marketing are also important to design education in China at different levels (see Figure 42).

The crosstabs of difficulties of finding jobs for young design graduates and age (E14* A02). In the cross-tabulation of difficulties of finding jobs for young design graduates and age (Pearson's Chi-square $=.026)$, the results explain that age groups $1(23<$ years old $), 2(23-26$ 
years old), and 4 (>30 years old) noticeably supported the statement. In contrast, age group 3 (27-30 years old) slightly did not support the statement. The percentage from all negative scale levels, strongly disagree, disagree, and slightly disagree, in the group 3 were $42.8 \%$ (18) and all positive scale levels responses added up to 38\% (16) (see Figure 43). Because the majority of respondents in support were in groups 1 and $2(60.7 \% / 119)$, their agreement with the statement confirms that young design graduates are having difficulties finding jobs in the labour market in China.

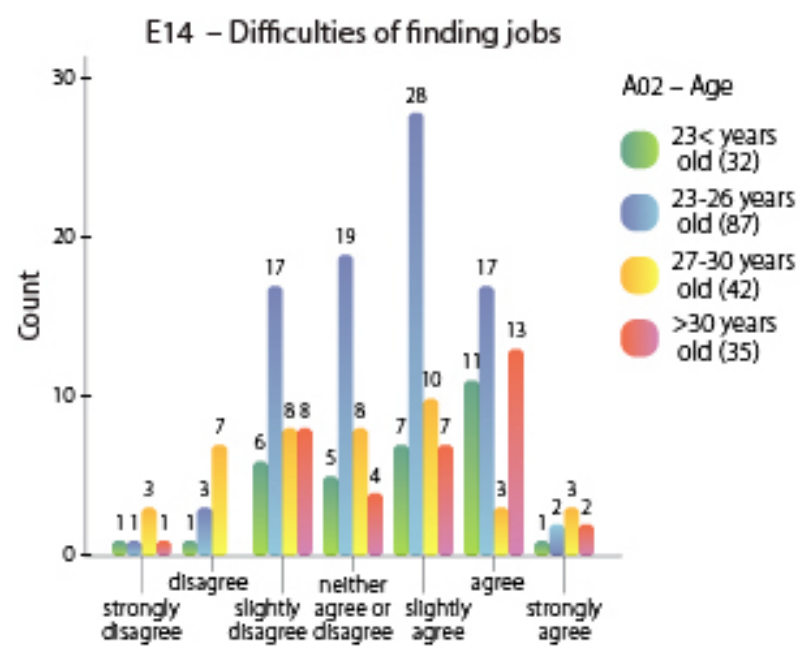

Figure 43. The crosstabs of difficulties of finding jobs for young design graduates and age $(\mathrm{E} 14 * \mathrm{~A} 02)$

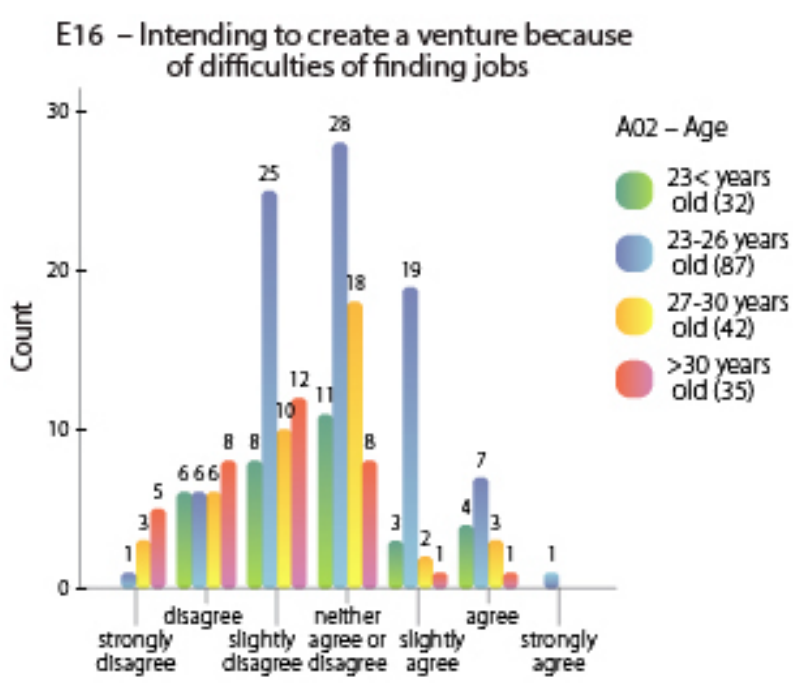

Figure 44. The crosstabs of venture creation because of difficulties' finding jobs and age $(\mathrm{E} 16 * \mathrm{~A} 02)$

\section{The crosstabs of venture creation because of difficulties' finding jobs and age (E16 *}

A02). In the cross-tabulation of venture creation as a result of difficulties finding jobs and age (Pearson's Chi-square $=.011$ ), the results illustrate that all respondents from the four different 
age groups disagreed with the statement. This means that respondents from age younger than twenty three to older than thirty do not think that if design graduates cannot find suitable design jobs, then they should intend to start developing their own business (see Figure 44). Precisely, group 4 demonstrated a sharper rate at the scale level of disagreement, $71.5 \%$ (25). Conversely, other groups' disagreement rates were moderate, $43.8 \%$ (14) in group 1, 36.7\% (32) in group 2, and $45.2 \%$ (19) in group 3 .

In sum, based on the factor analysis, eight entrepreneurial motivated factors were summarized by the researcher based on results of the KMO test. They including, knowledge (entrepreneurial and business), passion (egoistic passion), independency, difficulty of finding jobs (social pressure), second options (passivity), external support, resources (availability), and ease of start-up. Five types of creative individuals (clusters) were identified by the results of cluster analysis. These five clusters all have EIs but at different levels. Clusters 3 and 4 have higher EIs than others. However, they are all driven by diverse motivated factors. Meanwhile, findings from all crosstabs analysis explain imperative aspects that are pertinent to the research questions at different levels. For instance, respondents with bachelor's degrees prefer creative entrepreneurial programs are design-business-mixed programs. 


\subsection{Conclusions}

Creative entrepreneurship education is a novel topic in China, albeit a few countries have already been developing it for many years such as the UK and Australia. On the one hand, the major purpose of implementing creative entrepreneurship education is to complement the competence of creative graduates and enhance the development of self-employment and entrepreneurship; on the other hand, it also fertilizes the number of creative entrepreneurs to become bigger and sustain the creative industry's growth. In China, hundreds of thousands of designers are graduating from enormous design schools every year. Problems caused by the mass enrollment and expansion of design education cause failures to contribute to the growth of creative industries in China. Many young creative Chinese design graduates need to deal with aggressive global competition. Proposing an approach of introducing creative entrepreneurship education into design education in China could be a positive solution to tackle issues faced by design education. It could also increase the amount of potential creative entrepreneurs in China.

Nevertheless, before the actual proposal is formed, the factors that motivate and drive Chinese creative graduates to be self-employed need to be investigated. Additionally, in order to establish specific suggestions for developing creative entrepreneurship education, the types of creative graduates that can benefit from such education need to be identified. The researcher utilized a mixed method to investigate entrepreneurial aspirations, motivations, and intentions among a referential number of Chinese designers and provided possible advice for the future development of creative entrepreneurship education in China. Because there are not any existing studies based on the purpose and focus of this study, this study is a primary, leading study, especially for Chinese scholars. This study will also help to develop a database for the future 
research and illustrate a picture of something unknown in entrepreneurial aspirations among designers in China.

\subsection{Discussions}

Results and findings from the interview and survey' analysis demonstrate the positivity of entrepreneurial aspirations and intentions among Chinese creative graduates. They also illustrate explicit details about the factors and drivers that will motivate Chinese creative graduates to develop their potential entrepreneurship. Rationales, impediments, and difficulties that will obstruct Chinese designers' EIs are also presented. Meanwhile, suggestions for how to develop creative entrepreneurial programs in China were developed in order to answer the research questions:

1. What are the entrepreneurial drivers that would stimulate the development of selfemployment and entrepreneurship among designers in China?

2. Who would be potential creative entrepreneurs in China?

3. What aspects should be taken into consideration when designing creative entrepreneurship education for designers in China?

Discussions were divided into four subsections: discussions for general entrepreneurial intentions and motivated drivers (to answer question1), discussions about specific designers' entrepreneurial behaviours (to answer question 2), discussions about design education (to answer question 3), and future suggestions for creative entrepreneurial education programs (which also addressed the third research question).

\subsubsection{Discussion for general entrepreneurial intentions and motivated drivers.}

Findings from the interview and statistical analysis demonstrate that Chinese designers' EIs are at the middle level and higher (level 2 to 3). Their EIs are positive, and their entrepreneurial 
aspirations and intentions are driven by eight major factors (knowledge, passion, resources, independency, ease of start-up, difficulty of finding job, second option, and external support). Designers' EIs are not very strong (the final level in Figure 8) due to entrepreneurial impediments and obstacles. Findings from the interview analysis uncovered entrepreneurial impediments and obstacles, such as the lack of knowledge about entrepreneurship, production, business models, and the lack of self-efficacy. These impediments prevent designers from transforming their entrepreneurial aspirations and intentions into actions. If designers would change these impediments from disadvantages to advantages, these obstacles could be the drivers and catalysts for the development of designers' entrepreneurial potentials.

In fact, the eight essential factors would stimulate Chinese designers to transform their entrepreneurial aspirations and intentions into action. From the survey's analysis, knowledge is summed up by five variables, D14, D15, D16, D17, and D18. For passion and resources, each is summed up by variables: C03, C04, C05, and C06 for passion; and D01, D02, D03, and D05 for resources. Independency is summed up by three variables, C02, C09, and C11. For the rest of the drivers, each is summed up by two variables. Ease of start-up is summed up by C12 and C13. Difficulty of finding a job is summed up by $\mathrm{C} 14$ and $\mathrm{C} 15$. Second option is summed up by $\mathrm{C} 16$ and C17, and external support is summed up by D08 and D11.

For knowledge, it can see that many Chinese designers cease their entrepreneurial aspirations and intentions because they lack of knowledge about the economy, business, manufacturing, production, brand development, marketing, e-marketing, entrepreneurship, and management (see Appendix 3, set D). Ball's (2002) study also suggests that art and design graduates lack of business knowledge and business awareness. These impediments will prevent creative graduates' performance, either in self-employment or in working environments. 
Therefore, this implies that entrepreneurial knowledge would be a motivational driver for Chinese creative graduates to engage with entrepreneurship if they had the useful knowledge and skills.

The second entrepreneurial impediment is passion. Shane et al. (2003) suggest that egoistic passion refers to individuals' intentions to start their own ventures based on their own interests and enthusiasm. In fact, in order to persevere, this egoistic passion and personal interest needs self-confidence, self-development, and self-achievement. This demonstrates that many Chinese creative graduates do not transform their entrepreneurial aspirations and intentions into actions because they lack confidence, and they do not have enough passion. This also means passion is a motivational driver that stimulates Chinese creative graduates. Interestingly, Ball's (2002) study also demonstrates that art and design students lack self-confidence. This means egoistic passion and self-confidence are highly important factors that motivate entrepreneurial Chinese designers.

Another entrepreneurial impediment is resources. The term resources, in this case, does not mean its literal meaning, and its usage in this study was explained in the factor analysis section. In particular, it refers to ideas for developing a business or a business model, personal perseverance, stamina, and time. Impediments, such as capital (funds, money, and investment), which was mentioned by all participants in the interview but was not highlighted by the SPSS, the Guanxi network, economic environment, and partners, are primary factors that impact designers' entrepreneurial aspirations and intentions.

Based on the variables, independency, ease of start, difficulty of finding jobs, second option, and external support are relatively important compared to knowledge, passion, and resources. However, these five drivers are still more significant than others that were not 
highlighted by the SPSS from set C and D, such as the following: C01, satisfaction of current situation (position or job); C10, personal fulfillment; D04, the Guanxi network (a personal social network); D06, mentors; D07, partners; and D09, funds and money. According to Bird's (1988) model, knowledge, passion, and independency are internal factors of entrepreneurial intention. Difficulty of finding jobs, second option, and external support are the external factors of entrepreneurial intention. Resources and ease of start-up are in between internal and external. The reasons for this are that knowledge, passion, and independency are related to personal abilities, traits, and personalities. Difficulty of finding jobs could mean social pressure because there are not many available jobs in the market. Second option seems to be an internal factor because it relates to passivity. However, reasons that cause the second option to replace the first option are external difficulties. For example, an individual may not be able to find an appropriate job; therefore, this individual may intend create a business. As previously mentioned in the factor

analysis section, resources are comprised of both internal factors and external factors. Ease of start-up, as a motivated driver, is not an internal or an external factor. For instance, the reasons a business might be easy to start could involve having skills and capacities, having external support, or having both. Unexpectedly, the Guanxi network, D04, was not highlighted by the SPSS as an important factor. This could be explained by designers and creative individuals more individualistic and idiosyncratic tendencies. They may consider the Guanxi network not as an imperative motivator for their business establishment.

\subsubsection{Discussion for specific designers' entrepreneurial behaviours. Entrepreneurial}

behaviour among designers can be split into two categories: entrepreneurial behaviour in the existing creative entrepreneurs and entrepreneurial behaviour in the potential creative entrepreneurs. The differences between these two categories are determined by gender, age, 
working experience, etc. Behavioural diversity will affect the suggestions for the development of creative entrepreneurial programs.

Firstly, establishing design consulting firms is not as favorable for potential creative entrepreneurs as it used to be. Among the existing enterprises developed by designers, the number of design firms is larger than the number of non-design firms (see Figure 28). Potential creative entrepreneurs are favorable for different categories in their future enterprises (see Figure 30). The categories of IT products, digital devices, internet technologies, and gaming are the most popular future enterprises for potential male creative entrepreneurs. One of the obvious reasons to explain this is because of the ubiquitous phenomenon of the internet and the booming development of e-commence and technology in China (Millman et al., 2010).

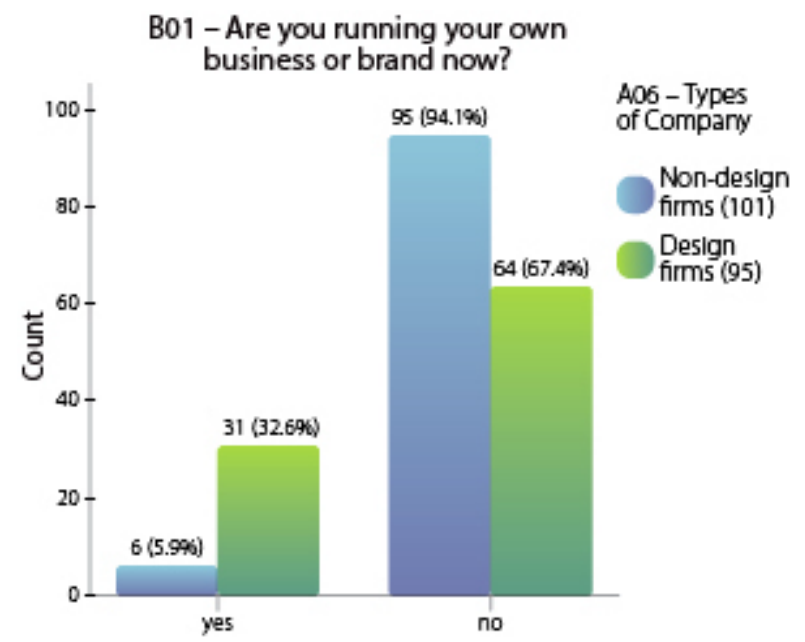

Figure 28. The crosstabs of entrepreneurship and type of company (B01* A06). 


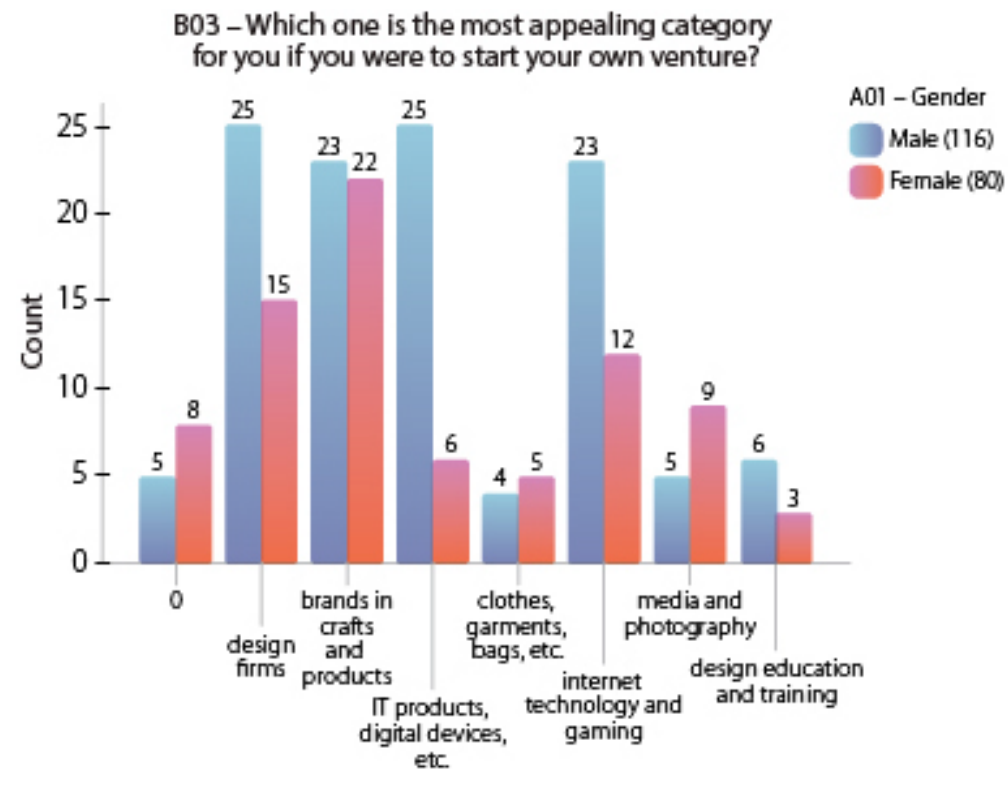

Figure 30. The crosstabs of start-up categories and gender (B03* A01).

Secondly, there is a gender disparity in the existing entrepreneurship among designers. The percentage of male creative entrepreneurs is bigger than females, $25 \%$ versus $10 \%$. However, the reasons causing this gender disparity in existing entrepreneurship are still unknown. Rationales behind this finding are likely connected to psychological and sociophenomenal influences.

Thirdly, as designers become older, the more working experience they have. This increases the probability that they will intend to create businesses. This does not explain existing entrepreneurship or the behaviour of creative entrepreneurs, but it can be applied to potential (non-existing) future entrepreneurship and the potential behaviours of creative entrepreneurs. Findings from the crosstabs of entrepreneurship and age $(\mathrm{B} 01 * \mathrm{~A} 02)$ demonstrated that respondents between the ages of twenty-three and twenty-six years old (group 2) had a higher percentage of entrepreneurship than the younger age groups (groups 1 and 2), and respondents 
above thirty years old (group 4) had a higher percentage of entrepreneurship among the older age groups (groups 3 and 4) (see Figure 25). This means that this finding does not follow the notion that, as designers become older, their entrepreneurial aspirations, intentions, and possibilities become higher.

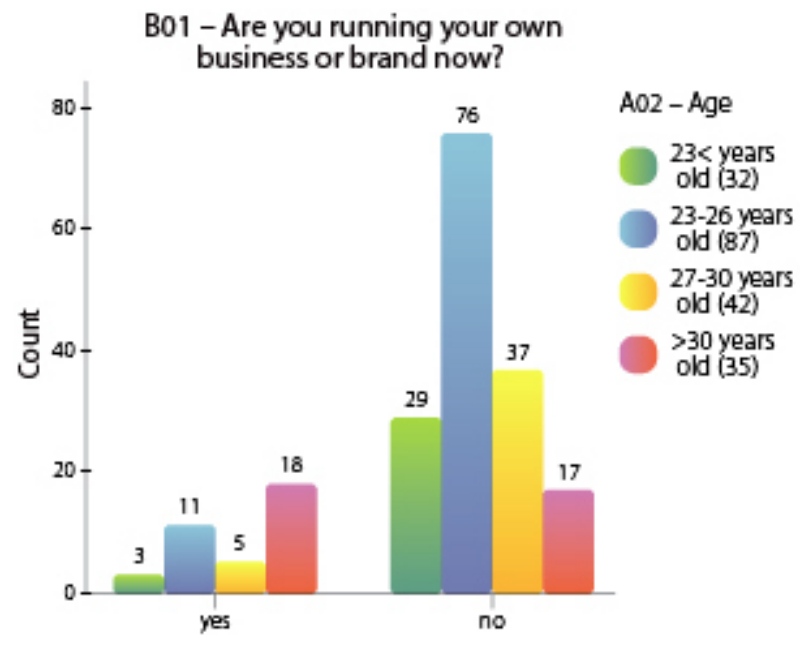

Figure 25. The crosstabs of entrepreneurship and age $(\mathrm{B} 01 * \mathrm{~A} 02)$.

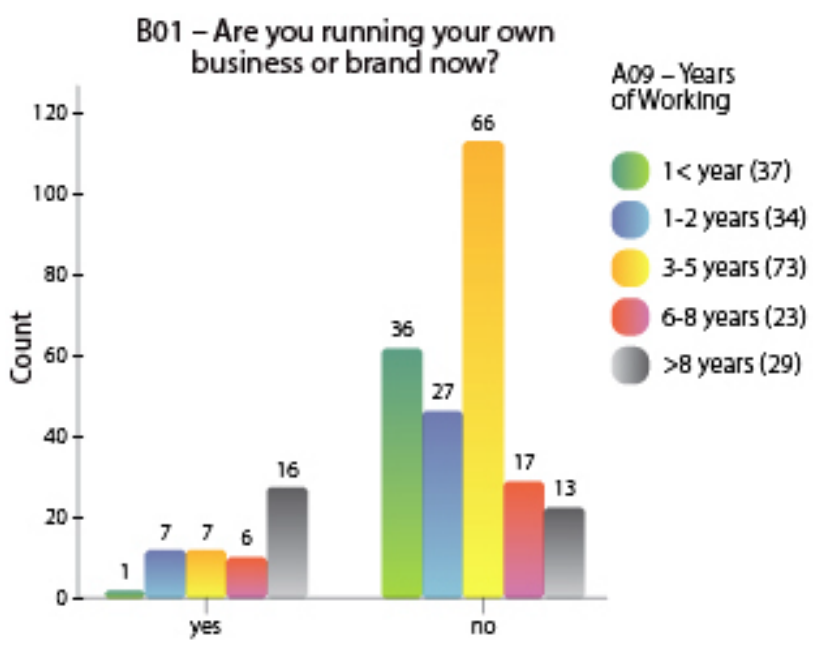

Figure 29. The crosstabs of entrepreneurship and years of working $(\mathrm{B} 01 * \mathrm{~A} 09)$.

Conversely, findings from the crosstabs of entrepreneurship and years of work experience $(\mathrm{B} 01 * \mathrm{~A} 09)$ show that the highest percentage of entrepreneurship exists in respondents who have the longest working experience (see Figure 29). This means that the more experience designers have, the more likely they are to developing creative design businesses of their own. It can be interpreted that, the older a designers becomes, the higher the feasibility that they will developing their own business. The results from the crosstabs of entrepreneurship and years of working (B01* A09) contradict with the results from the crosstabs of entrepreneurship and age $(\mathrm{B} 01 * \mathrm{~A} 02)$; however, the reasons behind this contradiction are unclear. 
Thirdly, and surprisingly, in design disciplines, designers with lower academic statuses were shown to have higher percentages of entrepreneurship (see Figure 27). This can be explained that the difficulty of job applications may drive designers with lower academic statuses for the possibility of entrepreneurship. This also can be interpreted to mean that designers who have lower levels of education would be more interested in entrepreneurship. This evidence matches $\mathrm{Wu}$ and Wu's (2008) study, "who are with diploma and undergraduate degree are more interested in start-up than those who are with postgraduate degree" (p. 763). However, in $\mathrm{Wu}$ and Wu's study, the studied sample was university students who were from non-design disciplines, such as business, engineering, biology, and physics. Based on this comparison, it can be interpreted that both individuals from design disciplines and individuals from non-design disciplines with lower educational statuses have stronger EIs.

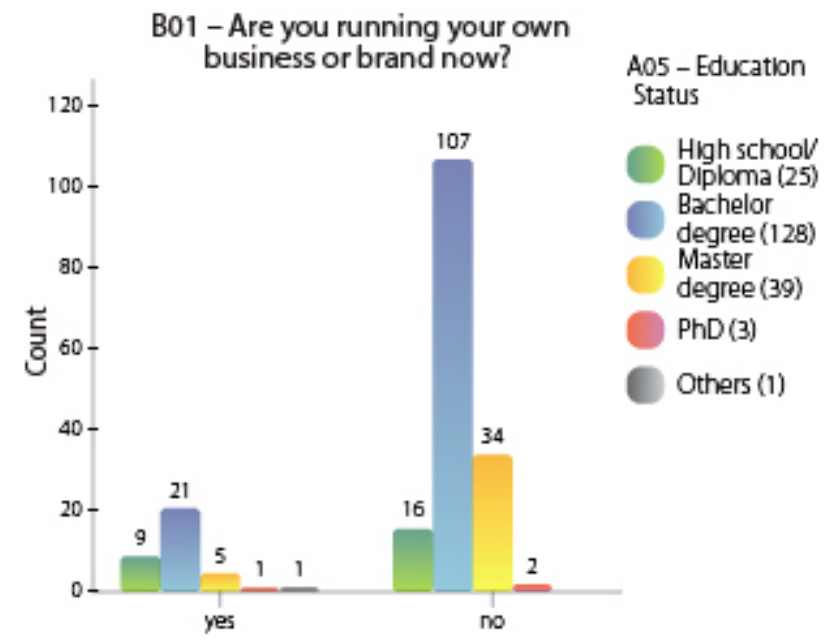

Figure 27. The crosstabs of entrepreneurship and education status (B01* A05).

5.1.3 Discussion for design education. Findings from the interview analysis, which pertained to designers' attitudes about China's design education and creative entrepreneurship 
education, provides a general rationale to expound problems existing in China's design education, which is slightly different to findings from the literature review. In the literature review, the problems existing in China's design education were found to be the disparity of resources and finances, the stagnation of pedagogy, inexperienced teachers, and students with inadequate capabilities. New findings elucidate that the problems existing in design education in China are caused by the disorganization of educational systems and structures, unsystematic design programs and curricula, and duplications of outdated curricula for teaching. However, findings from the interview analysis do not allude to the difficulty of finding jobs for young designer graduates, yet findings from the survey analysis do.

Findings from the survey analysis corroborate the fact that current design curricula are outdated, and design students' capabilities are inadequate. Instead of offering general information, findings from the survey analysis provide specific details. Findings from the crosstabs of the obsolete design courses, gender, and type of student all support the statement that design courses are regarded as obsolete. However, male designers seemed to agree with the statement more strongly than female designers. Designers with backgrounds in science and engineering strongly supported the statement in contrast to designers with backgrounds in the arts and humanities. A possible explanation for this could simply be that there are more male designers with backgrounds in science and engineering, while the majority of female designers have backgrounds in the arts and humanities.

The fact that design students lack the appropriate capacities is confirmed by the findings of the survey analysis. In particular, knowledge about design methods, project management, marketing (and e-marketing), and skills of using software were highlighted by the SPSS program. These are most important areas of knowledge that design graduates need to learn and 
improve. Designers with higher educational degrees, such as master's degrees, do not think they need to improve their knowledge about design methods, but designers with lower educational degrees, such as a bachelor's degrees or diplomas, do. This finding also supports findings from the interview analysis. It is suggested that design education for undergraduates should include more courses involving design methods. Surprisingly, designers who work for design firms agree that they need to learn more about design methods, whereas designers who work for non-design firms tend to agree less with this. This finding may point out that many design firms in China do not emphasize using design methods to solve design problems. Instead, they may more focus on providing aesthetic designs for their clients.

Moreover, skills and knowledge about software also is one of important requests among design graduates. Why design graduates think that they lack skills and knowledge about software and what kinds of software design graduates consider they need to learn about the most are still unknown. Knowledge about project management and marketing were highlighted by the SPSS as well. This can be explained by the fact that close to $50 \%$ respondents has more than three years of working experience. Many of them are senior designers and designer managers; they need this type of knowledge for their work. Based on findings from all analyses, designers support the approach of introducing creative entrepreneurship education into design education in China. Maybe participants realized the necessity of business skills and knowledge about business, management, and entrepreneurship. Perhaps, they see the need for these skills and knowledge, but they did not obtain them through their formal educations.

\subsubsection{Discussion for future suggestions about creative entrepreneurial programs.}

Existing creative entrepreneurship education varies. The first document instance of creative entrepreneurship education was the SPEED program in the UK (Rae, 2012), the second is the 
existing programs at the QUT in Australia, and the third was the workshop held by Ball (2012) in the School of Design at HKPU. How to establish creative entrepreneurial programs for Chinese design graduates is a vast challenge. Through all the findings and analyses of this study, couple of suggestions for establishing creative entrepreneurial programs for Chinese designer graduates can be extrapolated.

Firstly, in accordance with the findings from all analyses, the development of creative entrepreneurial education in China could start in design schools at the regular level, such as at the regular public universities, colleges, or private institutions. This is because $45.9 \%$ of existing creative entrepreneurs graduated from design schools at the regular level (tier two), and only $29.7 \%$ of the existing creative entrepreneurs graduated from design schools at the national level (tier one). In addition, programs should be established by design schools that are located in the three big economic areas, the BER, the YRDEZ, and the PRDEZ, because one of the purposes for developing creative entrepreneurship education is to increase self-employment rates and reduce the unemployment rate. The employment competition in these economic areas is severe. Creative entrepreneurial program would help design graduates from regular public universities to enter to another career option-self-employment.

Subsequently, creative entrepreneurial programs should be provided to undergraduate design students because findings from the statistical analysis suggest that designers with a bachelor's degrees or diplomas have higher entrepreneurial aspirations and intentions. These design graduates are more willing to develop their own businesses. Moreover, different programs should be designed for design graduates driven by diverse motivational factors. In this study, the cluster analysis revealed five types of design clusters, which the future development of creative entrepreneurship education should target. 
Thirdly, Design schools at the regular level should establish systematic and creative entrepreneurial programs that are available to undergraduate designers. These types of creative programs should focus on how to encourage, facilitate, and support design students in their entrepreneurship. Meanwhile, these programs should advocate entrepreneurial awareness in students as well as the significance of creating enterprises. Design students can not only learn entrepreneurial knowledge and skills from these programs but also gain encouragement and support from their peers and supervisors. Thus, students' confidence can grow stronger through these programs. Designers in cluster 1 (I'm not an entrepreneur) and cluster 2 (I have no options) could apply for these programs. One reason is because designers in cluster 1 are unwilling to see themselves as entrepreneurs unless they gain support and encouragement. These programs would fulfill their needs. Designers in cluster 2 are motivated by the risks of unemployment. Because they decide to start their careers as entrepreneurs, they need not only entrepreneurial knowledge and skills but also full support and facilitation.

Finally, few creative entrepreneurial programs for specific types of entrepreneurs could be offered, such as programs for, craftsmen entrepreneurship, technological entrepreneurship, and gaming entrepreneurship. These are just a few possible directions for these programs. Colleges and some public universities with explicit focuses could develop these creative entrepreneurial programs. Designers in cluster 4 (It's all about good idea) could apply for these programs once they have come up with a good idea. Because their idea and direction are explicit, specific programs will help them to start their entrepreneurship. Next, vocational colleges and private institutions also could provide some short-term creative entrepreneurial courses to designers. Designers in cluster 3 (I want a side business) could benefit from these courses because these designers consider having entrepreneurship as a result of personal interest. 
Another type of creative entrepreneurial program might be offered by business schools for which designers in cluster 5 (business knowledge matters) could apply. Designers in cluster 5 believe that business and management knowledge are the key drivers for their entrepreneurship.

In sum, the four subsections addressed above provided discussions and descriptions with details to articulate the findings from the analyses. These discussions precisely answered the three research questions. Explanations about findings in design education were mentioned in the discussions as well. However, the study still carries some limitations.

\subsection{Limitations}

Although a mixed method is utilized in this study for collecting and analyzing data, there are a couple of limitations in this study that need to be clarified. The first limitation is the questionnaires' design. Even though some questions in the survey were designed based on Ajzen's TPB (1991), Bird's (1988) model of EIs, and the study entrepreneurial motivations by Shane et al. (2003), they were still not enough. In fact, there were only two sets of questions pertinent to entrepreneurial aspirations, motivations, and intentions. This may affect the adequacy and legitimacy of data collection. Additionally, the survey was designed not only for gathering data to investigate Chinese designers' entrepreneurial aspirations, motivations, and intentions but also for understanding Chinese designers' attitudes about design curricula and creative entrepreneurial education. Thus, the specificity of the questionnaires could be argued against. Moreover, a section inquiring about attitudes concerning introducing creative entrepreneurship education into design education in China was missing in the survey.

The second limitation has to do with the sampling methods and sample size. Due to the limitation of time and budget, the researcher decided to use a convenient-purposive sampling for collecting interview data and an exponential non-discriminative snowball sampling for collecting 
survey data. Although qualitative research does not require a large sample size, the interviews in this study only included six participants. At the same time it may be noted that the interviews laid a basis for more detailed quantitative research.

It could be argued that snowball sampling as one of non-probability sampling methods be considered as a non-random sampling method (Explorable.com, 2009). The randomness of the survey data could be questioned. Moreover, the survey's samples were collected from different areas in China because the researcher did not select samples from a specific and geographic location, such as an area, a province, or a city. Instead, samples were collected through a social network. The number of Chinese designers is enormous. As a referential number, the survey's sample size may have been too small. Of the 229 samples, 196 were relevant. Thus, sampling methods and sample sizes may affect the objectivity of this study.

The third limitation is related to a defect of translation, from one language to another language and vice versa. This defect also occurs in the procedure of developing questionnaires for collecting data. In spite of the fact that the researcher has been reducing as many translation lapses as possible during the process of gathering data, there may be some interpretation errors in the study. For instance, all interview questions were written in English first then translated to Chinese later. There might be a few defects caused by the translating process. The defects of the translation may affect the original meaning of the interview questions as well. The researcher used Mandarin as the interview language to assemble data. After the interview, the researcher transcoded audio records into context. Then he translated all the transcripts from Mandarin to English. As a result, this second translation process may have caused a certain percentage of defects. This issue is the major limitation of this study. 
The fourth limitation was that the sampling category was only targeted at incumbent designers. The benefit of this type of sample is that incumbent designers have both work and school experiences. Therefore, they were the convenient sample for this study. However, one type of sample cannot provide enough information to study creative entrepreneurship education in China on its own. Other types of sample should be included in future research, such as undergraduate students, postgraduate students, and scholars. For instance, design students, particularly in their last year of study, may reveal attitudes about entrepreneurial aspirations and motivations more precisely. Their attitudes about design curriculum and the relevancy of programs may be more valid than incumbent designers. For instance, because of the burgeoning development in technologies and the prevalence of using the internet, many design schools have started to re-design their curricula and pedagogic methods. Incumbent designers may not know about new curriculum designs or the relevancy of pedagogic. In addition, the entrepreneurial aspirations, motivations, and intentions of incumbent designers' may be discouraged because they become more realistic or passive after a few years of work.

Another limitation will be the usage of research method. The researcher utilized a mixed method to investigate entrepreneurial aspirations and intentions among Chinese designers in order to suggest the introduction of creative entrepreneurship education into design education in China. The mixed research method (combining qualitative and quantitative methods) is still considered a novel research method. Hence, using this type of research method may cause some uncertainties in this study.

Finally, the last limitation is the issue of distance. As a broad topic with complexities, the researcher was not physically in China to conduct this study, including the interviews and surveys. This may affect the study. For example, even though the interviews were audio 
recorded, participants' facial reactions, emotions, and expressions were not absorbed by the researcher. In sum, all of these limitations may affect this study at certain levels.

\subsection{Recommendations for Future Research}

Based on all the results, analyses, findings and discussions, the research questions in this study have been answered. However, there are a couple of points that need to be articulated for future studies. Firstly, the sampling methods could be reconsidered and sample size could be increased in future studies, whether they are qualitative or quantitative. Probability sampling methods such as random sampling, systematic random sampling, or multi-stage random sampling could be useful for collecting additional quantitative data. Despite the fact that there is no standard for sample sizes in qualitative research, Marshall (1996) suggests that sample sizes in qualitative research should be between ten and sixty, depending on the purpose of the study and the usage of the data (Morse, 2000; Sandelowski, 1995). Sample sizes for quantitative research should be around three-hundred or more (Bartlett, Kotrlik, \& Higgins, 2001), but this is not an ultimate criteria. Subsequently, future researchers should study other types of samples. Samples in this study are incumbent Chinese designers who hold degrees or diplomas from Chinese design schools, and the majority of them are product designers and graphic designers. Future samples could be wider. For instance, future researchers could recruit Chinese designers who have degrees from foreign design schools, Chinese designers from Hong Kong, Taiwan, Singapore, and other countries, or designers from other design disciplines, such as fashion design, architecture, or interior design. Design academia, professors, or students are other potential future samples for studying EIs.

Secondly, future researchers should concern about problems caused by translation. It is arduous to translate terminologies from one language to another language and maintain the 
consistency of their meanings. Translating lapses must be reduced in future studies. Moreover, future researchers could investigate other issues and areas. For instance, future researchers could study about problems pertaining to pedagogic methods between different design schools that are located in diverse geographical areas. Future researchers could also study issues that are under the topic of the development of creative entrepreneurship education in China. For example, what are the successful business models of creative entrepreneurship for Chinese designers? How different would the development of creative entrepreneurship education be between developed and developing countries or areas? What is the difference between creative entrepreneurship education in Hong Kong, Taiwan, Macau, Singapore, and mainland China?

\subsection{Conclusions}

The researcher utilized a mixed method to perceive entrepreneurial aspirations, motivations, and intentions among creative graduates in order to suggest a hypothetic approach - introducing creative entrepreneurship education into design education in order to tackle issues that are related to the development of creative industries, design education, and entrepreneurship education in China.

According to all of the explanations in the discussion section, the research questions were answered. Firstly, potential entrepreneurial drivers that would stimulate the development of creative entrepreneurship among designers in China are entrepreneurial knowledge and skills, entrepreneurial resources, independency, entrepreneurial facilitators, unemployment stress and pressure, personal passions and interests, and external support. Moreover, potential creative entrepreneurs have been categorized through statistical analysis into five clusters. They are all potential creative entrepreneurs, but they are all at different levels. The people in two of these categories may more easily become potential creative entrepreneurs. Others may not. For 
example, designers in cluster 1 may not look like potential creative entrepreneurs based on the findings. However, if they could acquire entrepreneurial knowledge, external support (i.e., government policies), entrepreneurial facilitation, and encouragement, they probably will become potential creative entrepreneurs. In group 2, designers look at entrepreneurship as a passive option or a last resort. Unemployment will drive them toward entrepreneurship. Designers in groups 3, 4, and 5 look at entrepreneurship more positively. Designers in cluster 3 are willing to develop a business as a hobby rather than a main career. In group 4, designers desire to have their own businesses, and they are passionate about entrepreneurship. However, the lack of facilitation, resources, and good ideas thwarts their entrepreneurial aspirations and intentions. Designers in group 5 contemplate that business knowledge and skills could aid them in becoming creative entrepreneurs.

In accordance with these findings, creative entrepreneurship education should develop various strategies, courses, and programs. Design schools at the regular public universities should provide systematic, full-time creative entrepreneurial programs. These programs would increase students' entrepreneurial awareness, support students' needs, provide facilitators to students, and encourage students to develop their entrepreneurship skills. In addition, the universities that offer these programs should be located in the developed-economic areas, such as the BER, the YRDEZ, and the PRDEZ. Some vocational colleges and private institutions could also establish creative entrepreneurial courses for design graduates. Moreover, creative entrepreneurial programs should be established divergently. Some of them are more general, and some are more specific (i.e., creative entrepreneurial programs for gaming entrepreneurship or craftsmen entrepreneurship). Conventional business schools could also develop creative 
entrepreneurial programs for design graduates. For example, designers in cluster 5 would want to apply for these programs.

Eventually, in order to systematize an appropriate proposal for how to develop creative entrepreneurial programs in design education in China, enormous studies and research are required. As one of the preliminary studies approaching introducing creative entrepreneurship into design education, the researcher decided to study creative designers' entrepreneurial aspirations, motivations, and intentions in order to determine what drives and motivates design students to become entrepreneurs. Therefore, this study could be a valuable resource for future researchers who intend to study topics related to creative entrepreneurship, creative entrepreneurship education, and design education in China. 


\section{References}

Abe, M., Troilo, M., Juneja, J. S., \& Narain, S. (2012). Policy guidebook for SME development in Asia and the Pacific. Thailand: United Nations publication.

Acs, Z. J., Desai, S., \& Hessels, J. (2008). Entrepreneurship, economic development and institutions. Small Business Economics, 31(3), 219-234 . doi:10.1007/s11187-008-9135-9

Ajzen, I. (1991). The theory of planned behavior. Organizational Behavior and Human Decision Processes, 50(2), 179-211. doi:10.1016/0749-5978(91)90020-T

Anderson, C. (2012). Makers: The new industrial revolution. Toronto: Signal.

Aridas, T., \& Pasquali, V. (2013, March 07). Countries with the Highest GDP Average Growth, 2003-2013. Retrieved April 7, 2015, from Global Finance: https://www.gfmag.com/global-data/economic-data/countries-highest-gdp-growth

Atherton, A. (2007). Preparing for business start-up: "Pre-start" activities in the new venture creation dynamic. Journal of Small Business and Enterprise Development, 14(3), 404417. doi:10.1108/14626000710773510

Bai, L. (2006). Graduate unemployment: Dilemmas and challenges in China's move to mass higher education. The China Quarterly, 185, 128-144.

Ball, L. (2002). Preparing graduates in art and design to meet the challenges of working in the creative industries: a new model for work. Art, Design \& Communication in Higher Education, 1(1), 10-24. 
Ball, R., \& Overhill, H. (2012). Design Direct: How to start your own micro brand. Hong Kong: PTeC.

Bartlett, J. E., Kotrlik, J. W., \& Higgins, C. C. (2001). Organizational research: Determining appropriate sample size in survey research. Information Technology, Learning, and Performance Journal, 19(1), 43-50.

Begley, T. M., \& Boyd, D. P. (1987). Psychological characteristics associated with performance in entrepreneurial firms and smaller businesses. Journal of Business Venturing, 2(1), 7993. doi:10.1016/0883-9026(87)90020-6

Bird, B. (1988). Implementing entrepreneurial ideas: The case for intention. Academy of Management Review, 13(3), 442-453. doi:10.5465/AMR.1988.4306970

Bischoff, P. (2014, July 2). China's second-biggest ecommerce firm JD launches Kickstarter-like crowdfunding site. Retrieved March 19, 2015, from TechinAsia: https://www.techinasia.com/chinas-secondbiggest-ecommerce-firm-jd-launcheskickstarterlike-crowdfunding-site/

Bosma, N., Levie, J., Bygrave, W. D., Justo, R., Lepouter, J., \& Terjesen, S. (2010). Global entrepreneurship monitor: 2009 executive report. Retrieved October 25, 2014, from http://static.wamda.com/web/uploads/resources/GEM_2009_Global_Report_Rev_14041 $0 . p d f$

Bouma, G. D., Ling, R., \& Wilkinson, L. (2012). The research process (Second Canadian ed.). Don Mills, Ontario: Oxford University Press. 
Boyd, N. G., \& Vozikis, G. S. (1994). The influence of self-efficacy on the development of entrepreneurial intentions and actions. Entrepreneurship Theory and Practice, 18, 63-63.

CAFA. (2015). Schools and Colleges. Retrieved March 17, 2015, from China Central Academy of Fina Arts: http://www.cafa.edu.cn/aboutcafa/lan/?c=1105

Carey, C., \& Matlay, H. (2010). Creative disciplines education: A model for assessing ideas in entrepreneurship education? Education + Training, 52(8/9), 694 - 709. doi:10.1108/00400911011088999

Carey, C., \& Naudin, A. (2006). Enterprise curriculum for creative industries students: An exploration of current attitudes and issues. Education p Training, 48(7), 518-531. doi:10.1108/00400910610705908

Carter, N. M., Gartner, W. B., \& Reynolds, P. D. (1996). Exploring start-up event sequences. Journal of Business Venturing, 11, 151-166.

Castree, N., Kitchin, R., \& Rogers, A. (2013). A Dictionary of Human Geography. Oxford: Oxford University Press.

Cerny, B. A., \& Kaiser, H. F. (1977). A study of a measure of sampling adequacy for factoranalytic correlation matrices. Multivariate Behavioral Research, 12(1), 43-47.

Chen, D. Y. (2004). China's mass higher education: Problem, analysis, and solutions. Asia Pacific Education Review, 5(1), 23-33.

Chen, W. (2008). Sheji shi shengcun xianzhuang zhi diaocha baogao [An investigation report of designers' survival]. Meishu Bao [Art Journal](034), 1. 
China Education Center Ltd. (2015). Project 211 and 985. Retrieved June 20, 2014, from China Education Center Ltd.: http://www.chinaeducenter.com/en/cedu/ceduproject211.php

Chu, J.-f., Gao, F., \& Ma , W.-b. (2007). Shanghai chengshi yu chuangyi yuanqu xietiao fazhan yanjiu [A study of coordinating urban development and creative industrial parks in Shanghai]. Zhongguo renkou, ziyuan yu huanjing [China Population, Resources and Environment] , 6(17), 139-142.

Colwell, S., \& Carter, E. (2012). Introduction to Statistics for Social Sciences. New York: McGraw-Hill Higher Education.

Davey, G., Lian, C., \& Higgins, L. (2007). The university entrance examination system in China. Journal of further and higher education, 31(4), 385-396. doi:doi: $10.1080 / 03098770701625761$

DCMS. (2006). Developing entrepreneurship for the creative industries: Making the case for public investment . London: Department for Culture, Media and Sport, UK.

De Mozota, B. B. (2003). Design management: Using design to build brand value and corporate innovation. New York: Allworth Press.

DeCoster, J. (1998b, August 1). Overview of Factor Analysis. Retrieved April 5, 2015, from Statistical Notes: http://www.stat-help.com/factor.pdf

Ding, D. Z., Lan, G., \& Warner, M. (2001). A New Form of Chinese Human Resource Management? Personnel and Labour-Management Relations in Chinese Township and 
Village Enterprises: A Case-Study Approach. Industrial Relations Journal, 32(4), 328343.

Dobbs, R., Chen, Y., Orr, G., Manyika, J., Chui, M., \& Chang, E. (2013, March). China 's e-tail revolution. Retrieved March 19, 2015, from McKinsey \& Company: http://www.mckinsey.com/insights/asia-pacific/china_e-tailing

Doyle, C. (Ed.). (2011). A Dictionary of Marketing (3 ed.). Oxford: Oxford University Press.

Dziuban, C. D., \& Shirkey, E. C. (1974). When is a correlation matrix appropriate for factor analysis? . Psychological Bulletin, 81(6), 358-361. doi:10.1037/h0036316

Explorable.com. (2009). Snowball Sampling. Retrieved May 12, 2015, from Explorable.com: https://explorable.com/snowball-sampling

Flew, T. (2012). The creative industries: Culture and policy. London: Sage.

Florida, R. (2002). The rise of the creative class. New York: Basic Books .

Fung, A. S.-Y., \& Lo Choi, A. Y.-N. (2001). Design Education in China: New Proposals to Address Endemic Problems. International Journal Of Art \& Design Education, 20(2), 171-179.

Galloway, L., \& Brown, W. (2002). Entrepreneurship education at university: a driver in the creation of high growth firms? Education + Training, 44(8/9), 398 - 405. doi:10.1108/00400910210449231

Gibb, A. (2002). In pursuit of a new 'enterprise' and 'entrepreneurship' paradigm for learning: Creative destruction, new values, new ways of doing things and new combinations of 
knowledge. International Journal of Management Reviews, 4(3), 233-269. doi:10.1111/1468-2370.00086

Gibb, A. A. (1997). Small firms' training and competitiveness. Building upon the small business as a learning organisation. International Small Business Journal, 15(3), 13-29. doi:10.1177/0266242697153001

Gibb, A., \& Ritchie, J. (1982). Understanding the process of starting small businesses. International Small Business Journal, 1(1), 26-45. doi:10.1177/026624268200100102

Giudice, M., \& Ireland, C. (2014). Rise of the DEO: Leadership by Design. New Riders.

Government of Canada. (2015, February 9). Establishing a Joint Venture in China. Retrieved March 11, 2015, from The Canadian Trade Commissioner Service: http://www.tradecommissioner.gc.ca/eng/document.jsp?did=132234

Gunes, S. (2012). Design Entrepreneurship in Product Design Education. Procedia - Social and Behavioral Sciences, 64-68.

Hai, J., \& Siu, K. M. (2011). Design for all: Social innovation and service design education and practice in China. In P. L. Patrick Rau (Ed.), nternationalization, Design and Global Development (pp. 514-523). Orlando: Springer. doi:10.1007/978-3-642-21660-2_58

Hair, J. F., Black, W. C., Babin, B. J., \& Anderson, R. E. (2009). Multivariate data analysis (7th ed.). London: Prentice Hall. 
Hessels, J., Gelderen, M., \& Thurik, R. (2008). Entrepreneurial aspirations, motivations, and their drivers. Small Business Economics, 31(3), 323To-339. doi:10.1007/s11187-0089134-X

Howkins, J. (2007). The creative economy: How people make money from ides (updated ed.). London, England: Penguin Press (Original work published 2001).

Huang, F. (2013). WFOE Guide. Retrieved March 11, 2015, from Flora Huang Personal Website: http://www.shanghai-attorney.com/WFOE

Huenemann, R. W. (2013). Economic Reforms, 1978-Present. Oxford Bibliographies Online: Chinese Studies. doi:10.1093/obo/9780199920082-0008

Hunan University. (2008, October 3). About HNU Design. Retrieved July 1, 2014, from School of Design Hunan University: http://design.hnu.edu.cn/eng/index.php/about

Hynes, B. (1996). Entrepreneurship education and training - introducing entrepreneurship into non-business disciplines. Journal of European Industrial Training, 20(8), 10 - 17.

Investopedia, LLC. (2015). Foreign Direct Investment - FDI. Retrieved March 11, 2015, from Investopedia: http://www.investopedia.com/terms/f/fdi.asp

Jack, S. L., \& Anderson, A. R. (1999). Entrepreneurship education within the enterprise culture: Producing reflective practitioners. International Journal of Entrepreneurial Behaviour \& Research, 5(3), $110-125$. 
Jiangnan University. (2013). School of Design at Jiangnan University. Retrieved March 17, 2015, from School of Design at Jiangnan University: http://soden.jiangnan.edu.cn/en/List.asp?ID=77

Johnson, R. B., Onwuegbuzie, A. J., \& Turner, L. A. (2007). Toward a definition of mixed methods research. Journal of Mixed Methods Research, 1(2), 112-133. doi:10.1177/1558689806298224

Justice, L. (2012). China's Design Revolution. Cambridge, Massachusetts: The MIT Press.

Kaiser, H. F. (1970). A second generation little jiffy. Psychometrika, 35(4), 401-415. doi:10.1007/BF02291817

Kajalo, S., Rajala, R., \& Westerlund, M. (2007). Approaches to strategic alignment of business and information systems: A study on application service acquisitions. Journal of Systems and Information Technology, 9(2), 155-166. doi:10.1108/13287260710839238

Keane, M. (2009). Creative industries in China: four perspectives on social transformation. International Journal of Cultural Policy, 15(4), 431-443. doi:10.1080/10286630902989019

Keane, M. (2013). Creative industries in China. Cambridge, UK: Polity Press.

Kirby, D. A. (2004). Entrepreneurship education: can business schools meet the challenge. Education + Training, 46(8/9), 510-519. doi:10.1108/00400910410569632 
Krueger, N. F., Reilly, M. D., \& Carsrud, A. L. (2000). Competing models of entrepreneurial intentions. Journal of Business Venturing, 15(5-6), 411-432. doi:10.1016/S08839026(98)00033-0

Kuomintang. (2015, April 14). Retrieved March 14, 2015, from Wikipedia: http://en.wikipedia.org/wiki/Kuomintang

Law, J. (Ed.). (2009). A Dictionary of Business and Management (5 ed.). Oxford: Oxford University Press.

Li, F., Zhang, Y., \& Matlay, H. (2003). Entrepreneurship education in China. Education + Training, 45(8/9), 495-505. doi:10.1108/00400910310508883

Li, W. (2011). How creativity is changing China. (M. Keane, Ed., L. Hui, \& M. Guo, Trans.) London, UK: Bloomsbury Academic.

Li, X., \& Liu, L. (2010). Embedded guanxi networks, market guanxi networks and entrepreneurial growth in the Chinese context. Frontiers of Business Research in China, 4(3), 341-359. doi:10.1007/s11782-010-0101-4

Lin, J. (2011, June 17). Foreign designers popular. Retrieved July 10, 2014, from China Daily USA: http://usa.chinadaily.com.cn/epaper/2011-06/17/content_12723212.htm

Ling, J., \& Zhang, X. (2012). Zhongguo sheji chuangyi chanye fazhan xianzhuang yu yanjiu [Present conditions and research of China's creative design industry]. Chuangxin yu Sheji [Creation and Design], 4, 22-39. Retrieved from http://www.cnki.net/KCMS/detail/detail.aspx?QueryID=0\&CurRec=1\&recid=\&filename 
$=$ CYYS201204006 \&dbname $=$ CJFDLAST2013 $\& \mathrm{dbcode}=\mathrm{CJFQ} \& \mathrm{pr}=\& u r l i d=\& \mathrm{yx}=\& \mathrm{v}=$ MTMyOTBoMVQzcVRyV00xRnJDVVJMNmZZZVJtRmk3bFc3dk9KalRTZmJHNEg5 UE1xNDIGWW9SOGVYMUx1eFITN0Q=

Low, M. B., \& MacMillan, I. C. (1988). Entrepreneurship: Past research and future challenges. Journal of Management , 14(2), 139-161. doi:10.1177/014920638801400202

Marshall, M. N. (1996). Sampling for qualitative research. Family Practice, 13(6), 522-525. doi:10.1093/fampra/13.6.522

Matlay, H. (2005). Researching entrepreneurship and education: Part 1: What is entrepreneurship and does it matter? Education + Training, 47(8/9), 665 - 677. doi:10.1108/00400910510633198

Matlay, H. (2006). Researching entrepreneurship and education: Part 2: What is entrepreneurship education and does it matter? Education + Training, 48(8/9), 704 - 718. doi:10.1108/00400910610710119

Millman, C., Li, Z., Matlay, H., \& Wong, W.-c. (2010). Entrepreneurship education and students' internet entrepreneurship intentions: Evidence from Chinese HEIs. Journal of Small Business and Enterprise Development, 17(4), 569-590. doi:10.1108/14626001011088732

Millman, C., Matlay, H., \& Liu, F. (2008). Entrepreneurship education in China: a case study approach. Journal of Small Business and Enterprise Development, 15(4), 802 - 815. doi:10.1108/14626000810917870 
Ministry of Education of the People's Republic of China. (2006, October 2). Vocational Education in China. Retrieved March 11, 2015, from China.org.cn: http://www.china.org.cn/english/LivinginChina/185280.htm

Morse, J. M. (2000). Determining Sample Size. Qualitative Health Research, 10(1), 3 - 5. doi:10.1177/104973200129118183

Mu, Z. (2006). Woguo daxuesheng chuangye jiaoyu moshi tantao [Research on the mode of entrepreneurship education for undergraduates in China] . Journal of Higher Education, 79-84.

Muynck, B. d., \& Carriço, M. (2012). Design in China Mapping. Dutch Design Fashion Architecture. Shanghai: Movingcities. Retrieved from http://movingcities.org/projects/design-and-fashion-in-china-mappings/design/

Nabi, G., \& Holden, R. (2008). Graduate entrepreneurship: Intentions, education and training. Education + Training, 50(7), 545 - 551. doi:10.1108/00400910810909018

Newbigin, J. (2010, March 8). The creative economy: An introductory guide. Retrieved from British Council - Creative Economy: http://creativeconomy.britishcouncil.org/blog/10/03/08/creative-economy-introductoryguide/

ODM (own design manufacturer). (2013). Retrieved March 11, 2015, from Gartner: http://www.gartner.com/it-glossary/odm-own-design-manufacturer 
Original design manufacturer. (2015, March 9). Retrieved March 11, 2015, from Wikipedia: http://en.wikipedia.org/wiki/Original_design_manufacturer

Oxford University Press. (2015). Vocational Education and Training. Retrieved March 11, 2015, from Oxford Reference: http://www.oxfordreference.com/view/10.1093/oi/authority.20110803120135122

Penaluna , A., \& Penaluna, K. (2006). Business paradigms in Einstellung: Entrepreneurship education, a creative industries perspective. In Internationalizing Entrepreneurship Education and Training Conference (pp. 1-19). Brimingham: IntEnt.

Pontius, R. G., \& Cheuk, M. L. (2006). A generalized cross-tabulation matrix to compare softclassified maps at multiple resolutions. International Journal of Geographical Information Science, 20(1), 1-30. doi:10.1080/13658810500391024

Rae, D. (2005). Entrepreneurial learning: A narrative-based conceptual model. Journal of Small Business and Enterprise Development, 12(3), 323 - 335. doi: $10.1108 / 14626000510612259$

Rae, D. (2012). Action learning in new creative ventures. International Journal of Entrepreneurial Behaviour \& Research, 18(5), 603 - 623. doi:10.1108/13552551211253955

Rboten, D., O'Connor, E., \& Hackett, E. J. (2009). The act of collaborative creation and the art of integrative creativity: Originality, disciplinarity and interdisciplinarity. Thesis Eleven, 96(1), 83-108. doi:10.1177/0725513608099121 
Romesburg, C. H. (2004). Cluster analysis for researchers. Lulu Press.

Sandelowski, M. (1995). Sample size in qualitative research. Research in Nursing \& Health, 18(2), 179To-183. doi:10.1002/nur.4770180211

Scott, A. J. (2010). Cultural economy and the creative field of the city. Geografiska Annaler: Series B, Human Geography, 92(2), 115-130.

Shane, S., Locke, E. A., \& Collins, C. J. (2003). Entrepreneurial motivation. Human Resource Management Review, 13(2), 257-279. doi:10.1016/S1053-4822(03)00017-2

Shaver, K. G., \& Scott, L. R. (1991). Person, process, choice: The psychology of new venture creation. Entrepreneurship Theory and Practice, 16(2), 23-45.

Simkin, J. (2014, August). Kuomintang. Retrieved March 14, 2015, from Spartacus Educational: http://spartacus-educational.com/CHINAkuomintang.htm

Sinha, K. (2008). China's creative imperative: How creativity is transforming society and business in China. Singapore: John Wiley \& Sons (Asia) Pte. Ltd.

Taormina, R. J., \& Lao, S. K.-M. (2007). Measuring Chinese entrepreneurial motivation: Personality and environmental influences. International Journal of Entrepreneurial Behaviour \& Research, 13(4), 200 - 221. doi:10.1108/13552550710759997

Teixeria, C. (2010). The entrepreneurial design curriculum: Design-based learning for knowledge-based economies. Design Studies, 31(4), 411-418. 
The Hong Kong Polytechnic University School of Design . (2014). Design Practices. Retrieved November 11, 2014, from PolyU Design: http://www.sd.polyu.edu.hk/en/studydetail/design-practices

Toloken, S. (2010, Setempber 13). Foreign designers open shop in South China. Retrieved July 10, 2014, from Plastics News: http://www.plasticsnews.com/article/20100913/NEWS/309139969/foreign-designersopen-shop-in-south-china

Tsinghua University. (2010). History. Retrieved March 17, 2015, from Academy of Arts \& Design, Tsinghua University: http://www.tsinghua.edu.cn/publish/aden/1746/index.html

UNCTAD. (2008). Creative economy report 2008: The challenge of assessing the creative economy towards informed policy-making. Geneva: United Nations Conference on Trade and Development .

Vanchan, V., \& Bryson, J. R. (2013). Design and manufacturing: Global competitiveness of industrial design companies in United States, Europe, and China. The Industry Studies Association Annual Conference, (pp. 1-28). Kansas City.

Verganti, R. (2009). Design driven innovation: Changing the rules of competition by radically innovating what things mean. (H. B. Press, Ed.) Boston, Massachusetts.

Vincett, P. S., \& Farlow, S. (2008). "Start-a-Business": An experiment in education through entrepreneurship. Journal of Small Business and Enterprise Development, 15(2), 274288. doi: $10.1108 / 14626000810871673$ 
Wang, S. Z. (1989). Chinese modern design: A retrospective. Design Issues, 6(1), 49-78.

White, D., \& Korotayev, A. (2004, January 2). Chapter 5: Statistical Analysis of Cross-Tabs . Retrieved April 5, 2015, from http://eclectic.ss.uci.edu/ drwhite/courses/StatGuide.pdf

Wong, W. S. (2011). Design History and Study in East Asia: Part 2 Greater China: People's Republic of China/Hong Kong/Taiwan. Journal of Design History, 24(4), 375-395. doi:10.1093/jdh/epr034

Wong, W. S. (2001). Detachment and unification: A Chinese graphic design history in greater China since 1979. Design Issues, 17(4), 51-71. doi:doi:10.1162/07479360152681092

Wong, W. S. (2005). Torn between Tradition and Modernity:the Future of Design Education Directions of China. International Conference on Design Education: Tradition and Modernity, 565-572.

Wu, S., \& Wu, L. (2008). The impact of higher education on entrepreneurial intentions of university students in China. Journal of Small Business and Enterprise Development, 15(4), 752 - 774. doi:10.1108/14626000810917843

Xiang, T. (2015, January 23). China's Crowdfunding Market as of 2014. Retrieved March 19, 2015, from TechNode: http://technode.com/2015/01/23/chinas-crowdfunding-market2014/

Xiao, P., \& Wu, Y. (2011). Zhongguo yishu sheji jiaoyu yanjiu zongshu [A summary of Chinese art and design education research]. Wenyi Shenghuo (Yishu Zhongguo) [Arts in China], $08,1$. 
Xinhua. (2012, February 2). Migrants go west as factories relocate. Retrieved March 18, 2015, from China.org.cn: http://www.china.org.cn/opinion/2012-02/02/content_24529016.htm

Yeung, I. Y., \& Tung, R. L. (1996). Achieving business success in confucian societies: The importance of guanxi (connections). Organizational Dynamics, 25(2), 54-65. doi:10.1016/S0090-2616(96)90025-X

Yu, L., Chan, C., \& Ireland, C. (2007). China's New Culture of Cool: Understanding the world's festest-growing market. Berkeley: New Riders.

Zha, Q. (2011a). Understanding China's move to mass higher education from a policy perspective. In R. Hayhoe, J. Li, J. Lin, \& Q. Zha, Portraits of 21 st century chinese universities: In the move to mass higher education (pp. 20-57). Dordrecht: Springer.

Zhang, H., \& Parker, L. (2008). China Design Now. London: V\&A Publishing.

Zhang, J. (2011, December 12). Top 8 economic rims in China. Retrieved March 11, 2015, from China.org.cn: http://www.china.org.cn/top10/2011-12/12/content_24100913_6.htm

Zhang, T. (2007). Urban development patterns in China: New, renewed, and ignored urban spaces. In S. Yan, \& D. Chengri (Eds.), In urbanization in China: Critical issues in an era of rapid growth (pp. 3-27). Lincoln Institute of Land Use Policy.

Zhou, Z. (2008). Shengcun bu jinjinshi mousheng: "Sheji" wenjuan diaocha de qishi [Survival does not only mean making a living - Enlightenment of the "Design Surivial" questionnaire]. Zhuangshi [Art \& Design], 07, 24-26. 


\section{Appendix 1. Interview Questions}

\section{Interview Questions:}

\section{BASIC INFORMATION OF INTERVIEWEES}

1.1 Would you tell me a bit about your backgrounds, such as your age, educational background, educational status, and your position?

1.2 What is your available email address?

\section{ENTREPRENEURIAL ASPIRATIONS}

2.1 Have you considered being a creative entrepreneur, entrepreneurial designer or selfemployed person? Why and why not?

2.2 What kind of reasons or influence have caused you to consider becoming an entrepreneur or self-employed person?

\section{REALITY IN DEVELOPING ENTERPRISES}

3.1 What would be the obstacles that hinder you from starting a new, self-employed venture?

3.2 What resources do you think would help you go through the barriers of starting a new brand or being self-employed?

3.3 If you know some of your friends, family members, or peers who have been already running their own creative ventures, what kind of creative ventures are they doing, and why? 3.4 Why do you think there are not many designers (industrial/product designers) starting their new ventures?

\section{ENTREPRENEURIAL EDUCATION}

4.1 Why do you think there are no creative entrepreneurial/business curricula for designers in design education in China?

4.2 What are your opinions about introducing creative entrepreneurial programs into design education in China?

4.3 As an incumbent designer in practice, would you suggest adding any coursework to the design school that you graduated from, in order to benefit students.

4.4 If you had an opportunity to experience creative entrepreneurial education, do you think you would prefer design-oriented entrepreneurial education or more business-oriented entrepreneurial education? Why? 


\section{Appendix 2. The Survey and Questionnaires}

\section{A survey for incumbent professional designers}

This survey includes three parts, the general information section, the selected section, and the ranking scale section. It takes you close to $\mathbf{1 5}$ minutes to finish all blanks [ ] and checkboxes $\square$. Please read all the notices at the beginning of each section (with gray background color) carefully before you start.

When you decide to select a checkbox $\square$, you can use the cursor checkbox. If you want to cancel the checkbox that you have selected, you can re-select that checkbox again by using the cursor. When you finish all the blanks and checkboxes, please recheck everything to make sure that you will not miss any question and any checkbox in this survey.

After you finish this survey, please push $\mathrm{Ctrl}+\mathrm{S}$ on your keyboard to save this file. When you finish this survey and save it, please send this file to weiwen.yu@carleton.ca. I am sorry about taking you so much time to finish this survey. Thank you for your participation.

\section{The General Information Section}

Notice: This is the general information section, which is including email address, gender, age, educational information, working information, etc. Please read each category carefully, select options that belong to your category, and fill up the blanks [ ] and the checkboxes $\square$.

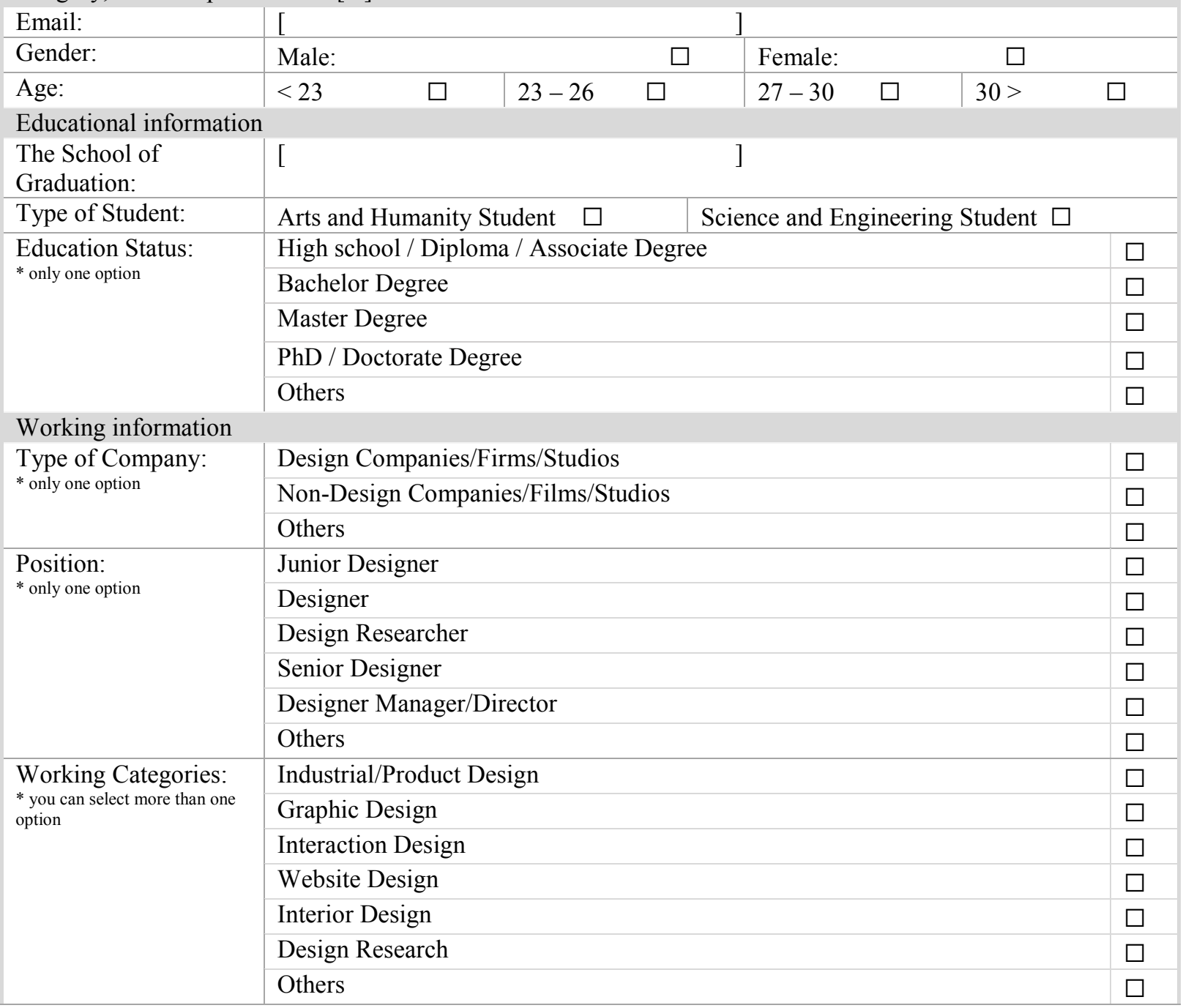




\begin{tabular}{|l|l|l|}
\hline $\begin{array}{l}\text { Years of working: } \\
\text { * only one option }\end{array}$ & $<1$ Year (less than a year) & $\square$ \\
\hline & 1 to 2 Years & $\square$ \\
\hline 3 to 5 Years & $\square$ \\
\hline & 6 to 8 Years & $\square$ \\
\hline & $>8$ Years (more than 8 years) & $\square$ \\
\hline
\end{tabular}

\section{Entrepreneurial Likelihood - The Selected Section}

Notice: This is the selected section. Please read each category carefully and select one option that mostly belongs to your category and selective the checkbox $(\square)$.

1. Are you operating or running your own business or brand now? * only one option

2. Have you thought about creating your own venture or being selfemployed?

* only one option

3. Which one is the most appealing category for you if you were to start your own venture?

* only one option

4. What is the likelihood of creating your own venture?

* only one option

5. Which group is the most influential one to inspire you intending to create your own business or brand? * only one option
Yes, I am.

No, I am not.

No (never have this consideration)

Before studying at the university

During the time at the university

After graduation and starting to work ( $1-3$ years)

After working 3 years

Design Companies/Firms/Studios (design consultancy)

Brands in Crafts and Products (designing, making, and selling artifacts, jewelry, small items, cards, paper notebooks, furniture, products for kitchens, etc.)

Brands' Development (designing, making, and

Personal selling IT products, digital devices, etc.)

Brands and Brands' Development (designing, making, and

Production selling clothes, garments, bags, etc.)

Internet Technology and Gaming (website design, apps development, games design, etc.)

Media and Photography (films, videos, photographing, editing, etc.)

Design Education and Training (teaching design methods and skills, teaching painting and drawing, educating students preparing for arts' exams, etc.)

Very soon (less than 6 months)

In $6-12$ months

In $1-2$ years

In $2-3$ years

In $3-5$ years

5 years later

Family Members and Relatives

Friends, Classmates, Schoolmates, and Alumni

Colleagues and Other Designers

Social Figures and Celebrities

Your Bosses

Others 


\section{The Ranking Scale Section}

Notice: In this section, you need to select one from seven ranking scales, strongly disagree, disagree, slightly disagree, neither agree or disagree, slightly agree, agree, and strongly agree. Please read each question carefully and select one check box $(\square)$ that you agree with.

\section{Entrepreneurial Intentions}

1) I am satisfied with my current situation (your working position and your job).

\begin{tabular}{l|l|l|l|l|l|l}
$\begin{array}{l}\text { Strongly } \\
\text { disagree }\end{array}$ & Disagree & $\begin{array}{l}\text { Slightly } \\
\text { Disagree }\end{array}$ & $\begin{array}{l}\text { Neither agree or } \\
\text { disagree }\end{array}$ & $\begin{array}{l}\text { Slightly } \\
\text { Agree }\end{array}$ & Agree & Strongly \\
$\square$ & $\square$ & $\square$ & $\square$ & $\square$ & $\square$ & $\square$
\end{tabular}

2) I like to work for myself rather than work for other people.

\begin{tabular}{l|l|l|l|l|l|l}
$\begin{array}{l}\text { Strongly } \\
\text { disagree }\end{array}$ & Disagree & $\begin{array}{l}\text { Slightly } \\
\text { Disagree }\end{array}$ & $\begin{array}{l}\text { Neither agree or } \\
\text { disagree }\end{array}$ & $\begin{array}{l}\text { Slightly } \\
\text { Agree }\end{array}$ & Agree & $\begin{array}{l}\text { Strongly } \\
\text { agree }\end{array}$ \\
$\square$ & $\square$ & $\square$ & $\square$ & $\square$ & $\square$ & $\square$
\end{tabular}

3) I think my business acumen is stronger than other people are.
Strongly
Disagree
Slightly
Disagree
Neither agree or
disagree

\begin{tabular}{l|l|l}
$\begin{array}{l}\text { Slightly } \\
\text { Agree }\end{array}$ & Agree & $\begin{array}{l}\text { Strongly } \\
\text { agree }\end{array}$ \\
$\square$ & & $\square$
\end{tabular}

4) I have many good ideas and concepts that can become good businesses.

\begin{tabular}{|c|c|c|c|c|c|c|}
\hline $\begin{array}{l}\text { Strongly } \\
\text { disagree } \\
\square\end{array}$ & $\begin{array}{l}\text { Disagree } \\
\square\end{array}$ & $\begin{array}{l}\text { Slightly } \\
\text { Disagree } \\
\square\end{array}$ & $\begin{array}{l}\text { Neither agree or } \\
\text { disagree } \\
\square\end{array}$ & $\begin{array}{l}\text { Slightly } \\
\text { Agree } \\
\square\end{array}$ & $\begin{array}{l}\text { Agree } \\
\square\end{array}$ & $\begin{array}{l}\text { Strongly } \\
\text { agree } \\
\square\end{array}$ \\
\hline \multicolumn{7}{|c|}{ 5) I want to be an entrepreneur. } \\
\hline $\begin{array}{l}\text { Strongly } \\
\text { disagree } \\
\square\end{array}$ & $\begin{array}{l}\text { Disagree } \\
\square\end{array}$ & $\begin{array}{l}\text { Slightly } \\
\text { Disagree } \\
\square\end{array}$ & $\begin{array}{l}\text { Neither agree or } \\
\text { disagree } \\
\square\end{array}$ & $\begin{array}{l}\text { Slightly } \\
\text { Agree } \\
\square\end{array}$ & $\begin{array}{l}\text { Agree } \\
\square\end{array}$ & $\begin{array}{l}\text { Strongly } \\
\text { agree } \\
\square\end{array}$ \\
\hline
\end{tabular}

6) I am confident that I can successfully create my own venture or brand.

\begin{tabular}{l|l|l|l|l|l|l}
$\begin{array}{l}\text { Strongly } \\
\text { disagree }\end{array}$ & Disagree & $\begin{array}{l}\text { Slightly } \\
\text { Disagree }\end{array}$ & $\begin{array}{l}\text { Neither agree or } \\
\text { disagree }\end{array}$ & $\begin{array}{l}\text { Slightly } \\
\text { Agree }\end{array}$ & Agree & Strongly \\
agree
\end{tabular}

7) Even if I fail many times of creating my own business, I will still keep on trying until I succeed.

\begin{tabular}{|l|l|l|l|l|l|l|}
$\begin{array}{l}\text { Strongly } \\
\text { disagree }\end{array}$ & Disagree & $\begin{array}{l}\text { Slightly } \\
\text { Disagree }\end{array}$ & Neither agree or & Slightly & Agree & Strongly \\
$\square$ & $\square$ & $\square$ & $\square$ & Agree & & agree \\
\hline$\square$ & $\square$ & $\square$ & $\square$ & $\square$ & $\square$
\end{tabular}

8) I think operating my own business, venture, or brand could be my second job or part-time job.
Strongly
disagree
Disagree
Slightly
Neither agree or
Slightly
Agree
Strongly
agree
9) If I could create my own business or brand, I felt I had more freedom.

\begin{tabular}{|l|l|l|l|l|l|l|}
$\begin{array}{l}\text { Strongly } \\
\text { disagree }\end{array}$ & Disagree & $\begin{array}{l}\text { Slightly } \\
\text { Disagree }\end{array}$ & $\begin{array}{l}\text { Neither agree or } \\
\text { disagree }\end{array}$ & $\begin{array}{l}\text { Slightly } \\
\text { Agree }\end{array}$ & Agree & Strongly \\
$\square$ & $\square$ & $\square$ & $\square$ & $\square$ & $\square$ & $\square$ \\
\hline
\end{tabular}

10) If I could create my own business or brand. I felt my personal values would be fulfilled.

\begin{tabular}{|c|c|c|c|c|c|c|}
\hline $\begin{array}{l}\text { Strongly } \\
\text { disagree } \\
\square\end{array}$ & $\begin{array}{l}\text { Disagree } \\
\square\end{array}$ & $\begin{array}{l}\text { Slightly } \\
\text { Disagree } \\
\square\end{array}$ & $\begin{array}{l}\text { Neither agree or } \\
\text { disagree } \\
\square\end{array}$ & $\begin{array}{l}\text { Slightly } \\
\text { Agree } \\
\square\end{array}$ & $\begin{array}{l}\text { Agree } \\
\square\end{array}$ & $\begin{array}{l}\text { Strongly } \\
\text { agree } \\
\square\end{array}$ \\
\hline \multicolumn{7}{|c|}{ 11) My own interests drive me to create my own business or brand. } \\
\hline $\begin{array}{l}\text { Strongly } \\
\text { disagree } \\
\square\end{array}$ & $\begin{array}{l}\text { Disagree } \\
\square\end{array}$ & $\begin{array}{l}\text { Slightly } \\
\text { Disagree } \\
\square\end{array}$ & $\begin{array}{l}\text { Neither agree or } \\
\text { disagree } \\
\square\end{array}$ & $\begin{array}{l}\text { Slightly } \\
\text { Agree } \\
\square\end{array}$ & $\begin{array}{l}\text { Agree } \\
\square\end{array}$ & $\begin{array}{l}\text { Strongly } \\
\text { agree } \\
\square\end{array}$ \\
\hline
\end{tabular}


12) I think creating a design-consulting firm is an easy way for a designer to create his or her own business.
Strongly
Disagree
Slightly
Disagree
Neither agree or
Slightly
Agree
Strongly
disagree
disagree
Agree
agree

$\square$

13) I think designing, making, selling products, and developing a brand is an easy way for a designer to create his or her own business.

\begin{tabular}{l|l|l|l|l|l|l}
$\begin{array}{l}\text { Strongly } \\
\text { disagree }\end{array}$ & Disagree & $\begin{array}{l}\text { Slightly } \\
\text { Disagree }\end{array}$ & $\begin{array}{l}\text { Neither agree or } \\
\text { disagree }\end{array}$ & $\begin{array}{l}\text { Slightly } \\
\text { Agree }\end{array}$ & Agree & $\begin{array}{l}\text { Strongly } \\
\text { agree }\end{array}$ \\
$\square$ & $\square$ & $\square$ & $\square$ & $\square$ & $\square$ & $\square$
\end{tabular}

14) I had a very difficult time finding my first suitable design job after my graduation.

\begin{tabular}{l|l|l|l|l|l|l}
$\begin{array}{l}\text { Strongly } \\
\text { disagree }\end{array}$ & Disagree & $\begin{array}{l}\text { Slightly } \\
\text { Disagree }\end{array}$ & $\begin{array}{l}\text { Neither agree or } \\
\text { disagree }\end{array}$ & Slightly & Agree & Strongly \\
$\square$ & $\square$ & $\square$ & Agree & & agree \\
$\square$ & $\square$ & $\square$ & $\square$ & $\square$ & $\square$
\end{tabular}

15) I had thought to seek for a non-design job if I could not find a suitable design job after my graduation.

\begin{tabular}{l|l|l|l|l|l|l}
$\begin{array}{l}\text { Strongly } \\
\text { disagree }\end{array}$ & Disagree & $\begin{array}{l}\text { Slightly } \\
\text { Disagree }\end{array}$ & $\begin{array}{l}\text { Neither agree or } \\
\text { disagree }\end{array}$ & $\begin{array}{l}\text { Slightly } \\
\text { Agree }\end{array}$ & Agree & $\begin{array}{l}\text { Strongly } \\
\text { agree }\end{array}$ \\
\hline
\end{tabular}

16) I had thought to start creating my own venture or brand if I could not find my first suitable design job after my graduation.

\begin{tabular}{l|l|l|l|l|l|l}
$\begin{array}{l}\text { Strongly } \\
\text { disagree }\end{array}$ & Disagree & $\begin{array}{l}\text { Slightly } \\
\text { Disagree }\end{array}$ & $\begin{array}{l}\text { Neither agree or } \\
\text { disagree }\end{array}$ & $\begin{array}{l}\text { Slightly } \\
\text { Agree }\end{array}$ & Agree & $\begin{array}{l}\text { Strongly } \\
\text { agree }\end{array}$ \\
$\square$ & $\square$ & $\square$ & $\square$ & $\square$ & $\square$ & $\square$
\end{tabular}

17) I had thought to apply for a postgraduate program or a doctoral program if I could not find my first suitable design job after my graduation.

\begin{tabular}{l|l|l|l|l|l|l|}
$\begin{array}{l}\text { Strongly } \\
\text { disagree }\end{array}$ & Disagree & $\begin{array}{l}\text { Slightly } \\
\text { Disagree }\end{array}$ & $\begin{array}{l}\text { Neither agree or } \\
\text { disagree }\end{array}$ & $\begin{array}{l}\text { Slightly } \\
\text { Agree }\end{array}$ & Agree & $\begin{array}{l}\text { Strongly } \\
\text { agree }\end{array}$ \\
$\square$ & $\square$ & $\square$ & $\square$ & $\square$ & $\square$ & $\square$
\end{tabular}

\section{Motivations and Obstacles for Entrepreneurship}

1) I consider a great idea or concept one of the most important aspects in order to create a new, self-employed venture or brand.

\begin{tabular}{l|l|l|l|l|l|l|}
$\begin{array}{l}\text { Strongly } \\
\text { disagree }\end{array}$ & Disagree & $\begin{array}{l}\text { Slightly } \\
\text { Disagree }\end{array}$ & $\begin{array}{l}\text { Neither agree or } \\
\text { disagree }\end{array}$ & $\begin{array}{l}\text { Slightly } \\
\text { Agree }\end{array}$ & Agree & $\begin{array}{l}\text { Strongly } \\
\text { agree }\end{array}$ \\
$\square$ & $\square$ & $\square$ & $\square$ & $\square$ & $\square$ & $\square$
\end{tabular}

2) I consider a business model one of the most important aspects in order to create a new, self-employed venture or brand.

\begin{tabular}{|l|l|l|l|l|l|l}
$\begin{array}{l}\text { Strongly } \\
\text { disagree }\end{array}$ & Disagree & $\begin{array}{l}\text { Slightly } \\
\text { Disagree }\end{array}$ & $\begin{array}{l}\text { Neither agree or } \\
\text { disagree }\end{array}$ & $\begin{array}{l}\text { Slightly } \\
\text { Agree }\end{array}$ & Agree & $\begin{array}{l}\text { Strongly } \\
\text { agree }\end{array}$ \\
\hline & & $\square$ & $\square$ & $\square$ & $\square$ & $\square$
\end{tabular}

3) I consider personal perseverance, stamina, and confidence one of the most important aspects in order to create a new, self-employed venture or brand.

\begin{tabular}{l|l|l|l|l|l|l}
$\begin{array}{l}\text { Strongly } \\
\text { disagree }\end{array}$ & Disagree & Slightly & Neither agree or & Slightly & Agree & Strongly \\
$\square$ & & Disagree & disagree & Agree & & \\
$\square$ & $\square$ & $\square$ & $\square$ & $\square$ & $\square$ & $\square$
\end{tabular}

4) I consider a powerful guan xi network (personal-social network) one of the most important aspects in order to create a new, self-employed venture or brand.

\begin{tabular}{|l|l|l|l|l|l|l|}
$\begin{array}{l}\text { Strongly } \\
\text { disagree }\end{array}$ & Disagree & $\begin{array}{l}\text { Slightly } \\
\text { Disagree }\end{array}$ & $\begin{array}{l}\text { Neither agree or } \\
\text { disagree }\end{array}$ & Slightly & Agree & Strongly \\
$\square$ & $\square$ & $\square$ & Agree & & agree \\
& & $\square$ & $\square$ & $\square$ & $\square$
\end{tabular}


5) I consider time one of the most important aspects in order to create a new, self-employed venture or brand.
Strongly
Disagree
Slightly
Neither agree or
Slightly
Agree
Strongly
disagree
Disagree
disagree
Agree
agree

6) I consider a mentor, a business-aiding association, or organization one of the most important aspects in order to create a new, self-employed venture or brand.

\begin{tabular}{l|l|l|l|l|l|l|}
$\begin{array}{l}\text { Strongly } \\
\text { disagree }\end{array}$ & Disagree & $\begin{array}{l}\text { Slightly } \\
\text { Disagree }\end{array}$ & $\begin{array}{l}\text { Neither agree or } \\
\text { disagree }\end{array}$ & Slightly & Agree & Strongly \\
$\square$ & $\square$ & $\square$ & $\square$ & Agree & & agree \\
& $\square$ & $\square$ & $\square$ & $\square$ & $\square$
\end{tabular}

7) I consider business partners one of the most important aspects in order to create a new, self-employed venture or brand.

\begin{tabular}{l|l|l|l|l|l|l|}
$\begin{array}{l}\text { Strongly } \\
\text { disagree }\end{array}$ & Disagree & $\begin{array}{l}\text { Slightly } \\
\text { Disagree }\end{array}$ & $\begin{array}{l}\text { Neither agree or } \\
\text { disagree }\end{array}$ & $\begin{array}{l}\text { Slightly } \\
\text { Agree }\end{array}$ & Agree & $\begin{array}{l}\text { Strongly } \\
\text { agree }\end{array}$
\end{tabular}

8) I consider a team (workers, secretaries, assistants, etc.) one of the most important aspects in order to create a new, self-employed venture or brand.

\begin{tabular}{l|l|l|l|l|l|l|}
$\begin{array}{l}\text { Strongly } \\
\text { disagree }\end{array}$ & Disagree & $\begin{array}{l}\text { Slightly } \\
\text { Disagree }\end{array}$ & $\begin{array}{l}\text { Neither agree or } \\
\text { disagree }\end{array}$ & $\begin{array}{l}\text { Slightly } \\
\text { Agree }\end{array}$ & Agree & $\begin{array}{l}\text { Strongly } \\
\text { agree }\end{array}$ \\
$\square$ & $\square$ & $\square$ & $\square$ & $\square$ & $\square$ & $\square$
\end{tabular}

9) I consider funds, money, and investment one of the most important aspects in order to create a new, selfemployed venture or brand.
Strongly
Disagree
Slightly
Neither agree or
Slightly
Agree
Strongly
Disagree
disagree
Agree
agree
10) I consider an incubating platform one of the most important aspects in order to create a new, self- employed venture or brand.

\begin{tabular}{l|l|l|l|l|l|l|}
$\begin{array}{l}\text { Strongly } \\
\text { disagree }\end{array}$ & Disagree & $\begin{array}{l}\text { Slightly } \\
\text { Disagree }\end{array}$ & $\begin{array}{l}\text { Neither agree or } \\
\text { disagree }\end{array}$ & $\begin{array}{l}\text { Slightly } \\
\text { Agree }\end{array}$ & Agree & $\begin{array}{l}\text { Strongly } \\
\text { agree }\end{array}$ \\
\hline$\square$
\end{tabular}

11) I consider the optimistic governmental policies one of the most important aspects in order to create a new, self-employed venture or brand.

\begin{tabular}{l|l|l|l|l|l|l}
$\begin{array}{l}\text { Strongly } \\
\text { disagree }\end{array}$ & Disagree & $\begin{array}{l}\text { Slightly } \\
\text { Disagree }\end{array}$ & $\begin{array}{l}\text { Neither agree or } \\
\text { disagree }\end{array}$ & $\begin{array}{l}\text { Slightly } \\
\text { Agree }\end{array}$ & Agree & $\begin{array}{l}\text { Strongly } \\
\text { agree }\end{array}$ \\
\cline { 2 - 4 } & & $\square$ & &
\end{tabular}

12) I consider the optimistic socioeconomic environment one of the most important aspects in order to create a new, self-employed venture or brand.
\begin{tabular}{l|l|l} 
Strongly & Disagree & Slightly
\end{tabular}
disagree
Disagree
Neither agree or
disagree
Slightly
Agree
Agree
Strongly agree

13) I consider appropriate suppliers (resources, materials, manufacturing, etc.) one of the most important aspects in order to create a new, self-employed venture or brand.
Strongly
Disagree
Slightly
Disagree
Neither agree or
Slightly
Agree
Strongly
disagree
Agree
agree

14) I consider the knowledge of economics and business one of the most important aspects in order to create a new, self-employed venture or brand.

\begin{tabular}{l|l|l|l|l|l|l}
$\begin{array}{l}\text { Strongly } \\
\text { disagree }\end{array}$ & Disagree & $\begin{array}{l}\text { Slightly } \\
\text { Disagree }\end{array}$ & $\begin{array}{l}\text { Neither agree or } \\
\text { disagree }\end{array}$ & $\begin{array}{l}\text { Slightly } \\
\text { Agree }\end{array}$ & Agree & $\begin{array}{l}\text { Strongly } \\
\text { agree }\end{array}$ \\
\hline
\end{tabular}


15) I consider the knowledge of manufacturing and production one of the most important aspects in order to create a new, self-employed venture or brand.

\begin{tabular}{|l|l|l|l|l|l|l|}
$\begin{array}{l}\text { Strongly } \\
\text { disagree }\end{array}$ & Disagree & $\begin{array}{l}\text { Slightly } \\
\text { Disagree }\end{array}$ & $\begin{array}{l}\text { Neither agree or } \\
\text { disagree }\end{array}$ & $\begin{array}{l}\text { Slightly } \\
\text { Agree }\end{array}$ & Agree & $\begin{array}{l}\text { Strongly } \\
\text { agree }\end{array}$ \\
\hline
\end{tabular}

16) I consider the knowledge of brand development one of the most important aspects in order to create a new, self-employed venture or brand.

\begin{tabular}{l|l|l|l|l|l|l|}
$\begin{array}{l}\text { Strongly } \\
\text { disagree }\end{array}$ & Disagree & $\begin{array}{l}\text { Slightly } \\
\text { Disagree }\end{array}$ & $\begin{array}{l}\text { Neither agree or } \\
\text { disagree }\end{array}$ & Slightly & Agree & $\begin{array}{l}\text { Strongly } \\
\text { agree }\end{array}$ \\
$\square$ & $\square$ & $\square$ & $\square$ & $\square$ & & \\
\hline
\end{tabular}

17) I consider the knowledge of marketing and e-marketing one of the most important aspects in order to create a new, self-employed venture or brand.
Strongly
Disagree
Slightly
Disagree
Neither agree or
Slightly
Agree
Strongly agree

18) I consider the knowledge of entrepreneurship and management one of the most important aspects in order to create a new, self-employed venture or brand.

\begin{tabular}{l|l|l|l|l|l|l|}
$\begin{array}{l}\text { Strongly } \\
\text { disagree }\end{array}$ & Disagree & $\begin{array}{l}\text { Slightly } \\
\text { Disagree }\end{array}$ & $\begin{array}{l}\text { Neither agree or } \\
\text { disagree }\end{array}$ & $\begin{array}{l}\text { Slightly } \\
\text { Agree }\end{array}$ & Agree & Strongly \\
agree
\end{tabular}

\section{Attitudes about Design Education in China}

1) The design courses that I took at university have become obsolete.
Strongly
disagree
Disagree
Slightly
Neither agree or
Slightly
disagree
Agree
Strongly
agree
Agree

2) The required courses that I took at university were very relevant to my major.
Strongly
Disagree
Slightly
Disagree
Neither agree or
disagree
Slightly
Agree
disagree

3) The options of elective courses at my university are very rare.

\begin{tabular}{l|l|l|l|l|l|l|}
$\begin{array}{l}\text { Strongly } \\
\text { disagree }\end{array}$ & Disagree & $\begin{array}{l}\text { Slightly } \\
\text { Disagree }\end{array}$ & $\begin{array}{l}\text { Neither agree or } \\
\text { disagree }\end{array}$ & Slightly & Agree & $\begin{array}{l}\text { Strongly } \\
\text { agree }\end{array}$ \\
$\square$ & $\square$ & $\square$ & $\square$ & $\square$ & & \\
\end{tabular}

4) I need to learn more about design research.

\begin{tabular}{|l|l|l|l|l|l|l|}
$\begin{array}{l}\text { Strongly } \\
\text { disagree }\end{array}$ & Disagree & $\begin{array}{l}\text { Slightly } \\
\text { Disagree }\end{array}$ & $\begin{array}{l}\text { Neither agree or } \\
\text { disagree }\end{array}$ & $\begin{array}{l}\text { Slightly } \\
\text { Agree }\end{array}$ & Agree & $\begin{array}{l}\text { Strongly } \\
\text { agree }\end{array}$ \\
$\square$ & $\square$ & $\square$ & $\square$ & $\square$ & $\square$ & $\square$
\end{tabular}

5) I need to learn more about design methods (design thinking, problem-solving, etc.).
Strongly
Disagree
Slightly
Disagree
Neither agree or
Slightly
Agree
Agree
disagree
$\square$
Strongly
agree

6) I need to learn more about software practices.
Strongly
disagree
Disagree
Slightly
Disagree
Neither agree or
Slightly
Agree
Agree
disagree
$\square$
7) I need to learn more about pragmatic design processing in real projects.
Strongly
Disagree
Slightly
Disagree
Neither agree or
disagree
$\square$
Slightly
Agree
disagree

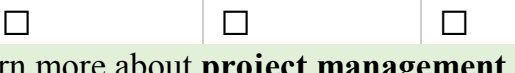

8) I need to learn more about project management. 


\begin{tabular}{|c|c|c|c|c|c|c|}
\hline $\begin{array}{l}\text { Strongly } \\
\text { disagree } \\
\square\end{array}$ & $\begin{array}{l}\text { Disagree } \\
\square\end{array}$ & $\begin{array}{l}\text { Slightly } \\
\text { Disagree } \\
\square\end{array}$ & $\begin{array}{l}\text { Neither agree or } \\
\text { disagree } \\
\square\end{array}$ & $\begin{array}{l}\text { Slightly } \\
\text { Agree } \\
\square\end{array}$ & $\begin{array}{l}\text { Agree } \\
\square\end{array}$ & $\begin{array}{l}\text { Strongly } \\
\text { agree } \\
\square\end{array}$ \\
\hline \multicolumn{7}{|c|}{ 9) I need to learn more about marketing and e-marketing. } \\
\hline $\begin{array}{l}\text { Strongly } \\
\text { disagree } \\
\square\end{array}$ & $\begin{array}{l}\text { Disagree } \\
\square\end{array}$ & $\begin{array}{l}\text { Slightly } \\
\text { Disagree } \\
\square\end{array}$ & $\begin{array}{l}\text { Neither agree or } \\
\text { disagree } \\
\square\end{array}$ & $\begin{array}{l}\text { Slightly } \\
\text { Agree } \\
\square\end{array}$ & $\begin{array}{l}\text { Agree } \\
\square\end{array}$ & $\begin{array}{l}\text { Strongly } \\
\text { agree } \\
\square\end{array}$ \\
\hline \multicolumn{7}{|c|}{ 10) I need to learn more about business management. } \\
\hline $\begin{array}{l}\text { Strongly } \\
\text { disagree } \\
\square\end{array}$ & $\begin{array}{l}\text { Disagree } \\
\square\end{array}$ & $\begin{array}{l}\text { Slightly } \\
\text { Disagree } \\
\square\end{array}$ & $\begin{array}{l}\text { Neither agree or } \\
\text { disagree } \\
\square\end{array}$ & $\begin{array}{l}\text { Slightly } \\
\text { Agree } \\
\square\end{array}$ & $\begin{array}{l}\text { Agree } \\
\square\end{array}$ & $\begin{array}{l}\text { Strongly } \\
\text { agree } \\
\square\end{array}$ \\
\hline \multicolumn{7}{|c|}{ 11) I need to learn more about entrepreneurial management. } \\
\hline $\begin{array}{l}\text { Strongly } \\
\text { disagree } \\
\square\end{array}$ & $\begin{array}{l}\text { Disagree } \\
\square\end{array}$ & $\begin{array}{l}\text { Slightly } \\
\text { Disagree } \\
\square\end{array}$ & $\begin{array}{l}\text { Neither agree or } \\
\text { disagree } \\
\square\end{array}$ & $\begin{array}{l}\text { Slightly } \\
\text { Agree } \\
\square\end{array}$ & $\begin{array}{l}\text { Agree } \\
\square\end{array}$ & $\begin{array}{l}\text { Strongly } \\
\text { agree } \\
\square\end{array}$ \\
\hline \multicolumn{7}{|c|}{ 12) I need to learn more about purchasing and selling management. } \\
\hline $\begin{array}{l}\text { Strongly } \\
\text { disagree } \\
\square\end{array}$ & $\begin{array}{l}\text { Disagree } \\
\square\end{array}$ & $\begin{array}{l}\text { Slightly } \\
\text { Disagree } \\
\square\end{array}$ & $\begin{array}{l}\text { Neither agree or } \\
\text { disagree } \\
\square\end{array}$ & $\begin{array}{l}\text { Slightly } \\
\text { Agree } \\
\square\end{array}$ & $\begin{array}{l}\text { Agree } \\
\square\end{array}$ & $\begin{array}{l}\text { Strongly } \\
\text { agree } \\
\square\end{array}$ \\
\hline \multicolumn{7}{|c|}{ 13) The educational system at my university is very suitable and qualified for educating young design students } \\
\hline $\begin{array}{l}\text { Strongly } \\
\text { disagree } \\
\square\end{array}$ & $\begin{array}{l}\text { Disagree } \\
\square\end{array}$ & $\begin{array}{l}\text { Slightly } \\
\text { Disagree } \\
\square\end{array}$ & $\begin{array}{l}\text { Neither agree or } \\
\text { disagree } \\
\square\end{array}$ & $\begin{array}{l}\text { Slightly } \\
\text { Agree } \\
\square\end{array}$ & $\begin{array}{l}\text { Agree } \\
\square\end{array}$ & $\begin{array}{l}\text { Strongly } \\
\text { agree } \\
\square\end{array}$ \\
\hline \multicolumn{7}{|c|}{ 14) Current young design graduates have difficulties finding a suitable design job after their graduation. } \\
\hline $\begin{array}{l}\text { Strongly } \\
\text { disagree } \\
\square\end{array}$ & $\begin{array}{l}\text { Disagree } \\
\square\end{array}$ & $\begin{array}{l}\text { Slightly } \\
\text { Disagree } \\
\square\end{array}$ & $\begin{array}{l}\text { Neither agree or } \\
\text { disagree } \\
\square\end{array}$ & $\begin{array}{l}\text { Slightly } \\
\text { Agree } \\
\square\end{array}$ & $\begin{array}{l}\text { Agree } \\
\square\end{array}$ & $\begin{array}{l}\text { Strongly } \\
\text { agree } \\
\square\end{array}$ \\
\hline \multicolumn{7}{|c|}{$\begin{array}{l}\text { 15) If current young design graduates could not find a suitable design job after their graduation, they should } \\
\text { seek for a non-design job. }\end{array}$} \\
\hline $\begin{array}{l}\text { Strongly } \\
\text { disagree } \\
\square\end{array}$ & $\begin{array}{l}\text { Disagree } \\
\square\end{array}$ & $\begin{array}{l}\text { Slightly } \\
\text { Disagree } \\
\square\end{array}$ & $\begin{array}{l}\text { Neither agree or } \\
\text { disagree } \\
\square\end{array}$ & $\begin{array}{l}\text { Slightly } \\
\text { Agree } \\
\square\end{array}$ & $\begin{array}{l}\text { Agree } \\
\square\end{array}$ & $\begin{array}{l}\text { Strongly } \\
\text { agree } \\
\square\end{array}$ \\
\hline \multicolumn{7}{|c|}{$\begin{array}{l}\text { 16) If current young design graduates could not find a suitable design job after their graduation, they should be } \\
\text { better to start creating their own, self-employed venture or brand. }\end{array}$} \\
\hline $\begin{array}{l}\text { Strongly } \\
\text { disagree } \\
\square\end{array}$ & $\begin{array}{l}\text { Disagree } \\
\square\end{array}$ & $\begin{array}{l}\text { Slightly } \\
\text { Disagree } \\
\square\end{array}$ & $\begin{array}{l}\text { Neither agree or } \\
\text { disagree } \\
\square\end{array}$ & $\begin{array}{l}\text { Slightly } \\
\text { Agree } \\
\square\end{array}$ & $\begin{array}{l}\text { Agree } \\
\square\end{array}$ & $\begin{array}{l}\text { Strongly } \\
\text { agree } \\
\square\end{array}$ \\
\hline \multicolumn{7}{|c|}{$\begin{array}{l}\text { 17) If current young design graduates could not find a suitable design job after their graduation, they should be } \\
\text { better to apply for a postgraduate program or a doctoral program. }\end{array}$} \\
\hline $\begin{array}{l}\text { Strongly } \\
\text { disagree } \\
\square\end{array}$ & $\begin{array}{l}\text { Disagree } \\
\square\end{array}$ & $\begin{array}{l}\text { Slightly } \\
\text { Disagree } \\
\square\end{array}$ & $\begin{array}{l}\text { Neither agree or } \\
\text { disagree } \\
\square\end{array}$ & $\begin{array}{l}\text { Slightly } \\
\text { Agree } \\
\square\end{array}$ & $\begin{array}{l}\text { Agree } \\
\square\end{array}$ & $\begin{array}{l}\text { Strongly } \\
\text { agree } \\
\square\end{array}$ \\
\hline
\end{tabular}

\section{The Final Question}

Notice: Please read each category carefully. You can only select one option ( $\square$ ) to answer the question below.

1. If you had an opportunity to experience entrepreneurial courses, which courses do you think you would prefer to? Design-oriented entrepreneurial courses Business-oriented entrepreneurial courses * only one option Design-Business-mixed entrepreneurial courses Internet-technological-oriented entrepreneurial courses 


\section{Appendix 3. The Code for Survey's Questions}

\section{A - The General Information Section}

A01 - Gender

A02 - Age

$$
\text { Male }=1 \quad \text { Female }=2
$$
$<23=1$
$23-26=2$
$27-30=3$
$30>=4$

A03 - The Rank of School

Projects 985/211 universities (1-tiered) = 1

Regular public universities (2-tiered) $\quad=2$

Junior colleges and private institutions $(3$-tiered $)=3$

A04 - Type of Student

Arts and Humanity $\quad=1 \quad$ Science and Engineering $=2$

A05 - Education Status

High school / Diploma / Associate Degree $\quad=1$

Bachelor Degree $\quad=2$

Master Degree $\quad=3$

$\mathrm{PhD} /$ Doctorate Degree $\quad=4$

Others $\quad=5$

A06 - Type of Company

Design Companies / Firms / Studios $\quad=1$

Non-Design Companies / Firms / Studios $\quad=0$

Others $\quad=0$

A07 - Position

$\begin{array}{ll}\text { Junior Designer } & =1 \\ \text { Designer } & =2 \\ \text { Design Researcher } & =3 \\ \text { Senior Designer } & =4 \\ \text { Designer Manager/Director } & =5 \\ \text { Others } & =6\end{array}$

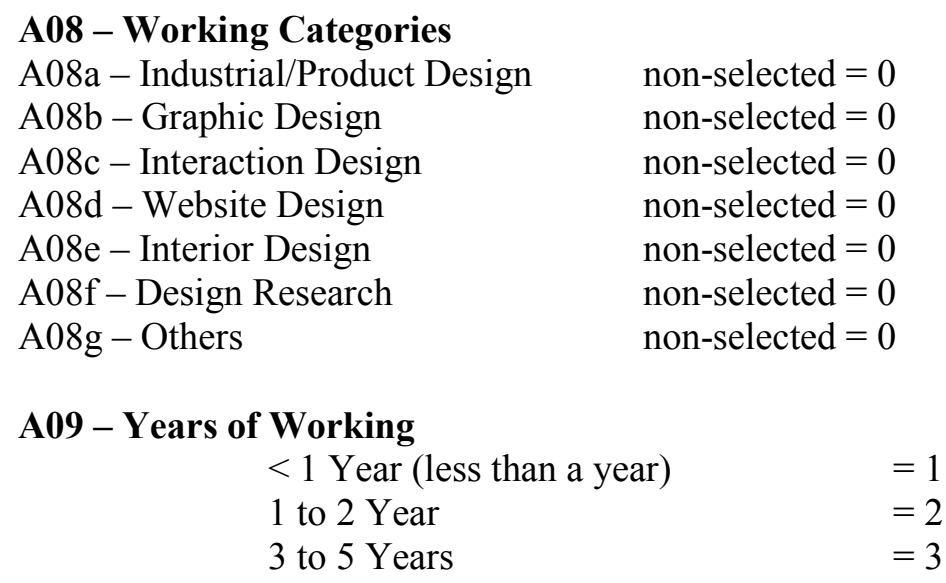


$\begin{array}{ll}6 \text { to } 8 \text { Years } & =4 \\ >8 \text { Years (more than } 8 \text { years) } & =5\end{array}$

B - Entrepreneurial Likelihood (the Selected Section)

B01 - Are you operating or running your own business or brand now?

Yes, I am. = $\quad$ No, I am not. $=2$

B02 - Have you thought about creating your own venture or being self-employed?

No (never have this consideration) $\quad=0$

Before studying at the university $\quad=1$

During the time at the university $\quad=2$

After graduation and starting to work $(1-3$ years $) \quad=3$

After working 3 years $\quad=4$

B03 - Which one is the most appealing category for you if you were to start your own venture?

No responsibility because selecting NO in B02 $\quad=\backslash(0)$

Design Companies/Firms/Studios $\quad=1$

Brands in Crafts and Products $\quad=2$

Brands' Development (... IT products, digital devices, etc.) $\quad=3$

Brands' Development (...clothes, garments, bags, etc.) $=4$

Internet Technology and Gaming $\quad=5$

Media and Photography $\quad=6$

Design Education and Training $\quad=7$

B04 - What is the likelihood of creating your own venture?

No responsibility because selecting YES in B01 $\quad=\backslash(0)$

No responsibility because selecting NO in B02 $\quad=\backslash(0)$

Very soon (less than 6 months) $\quad=1$

In $6-12$ months $\quad=2$

In $1-2$ years $\quad=3$

In $2-3$ years $\quad=4$

In $3-5$ years $=5$

5 years later $\quad=6$

B05 - Which group is the most influential one to inspire you intending to create your own business or brand?

No responsibility because selecting $\mathrm{NO}$ in $\mathrm{B} 02=\backslash(0)$

Family Members and Relatives $\quad=1$

Friends, Classmates, Schoolmates, and Alumni $=2$

Colleagues and Other Designers $\quad=3$

Social Figures and Celebrities $\quad=4$

Your Bosses $\quad=5$

Others $\quad=6$

$C, D, \& E-T h e$ Ranking Scale Section

Assess the following statements on a scale, where $1=$ strongly disagree and $7=$ strongly agree 


\section{C - Entrepreneurial Intentions}

C01. I am satisfied with my current situation (your working position and your job).

C02. I like to work for myself rather than work for other people.

C03. I think my business acumen is stronger than other people are.

C04. I have many good ideas and concepts that can become good businesses.

C05. I want to be an entrepreneur.

C06. I am confident that I can successfully create my own venture or brand.

C07. Even if I fail many times of creating my own business, I will still keep on trying until I succeed.

C08. I think operating my own business, venture, or brand could be my second job or part-time job.

C09. If I could create my own business or brand, I felt I had more freedom.

C10. If I could create my own business or brand. I felt my personal values would be fulfilled.

C11. My own interests drive me to create my own business or brand.

C12. I think creating a design-consulting firm is an easy way for a designer to create his or her own business.

C13. I think designing, making, selling products, and developing a brand is an easy way for a designer to create his or her own business.

C14. I had a very difficult time finding my first suitable design job after my graduation.

C15. I had thought to seek for a non-design job if I could not find a suitable design job after my graduation.

C16. I had thought to start creating my own venture or brand if I could not find my first suitable design job after my graduation.

C17. I had thought to apply for a postgraduate program or a doctoral program if I could not find my first suitable design job after my graduation.

D - Motivations and Obstacles for Entrepreneurship

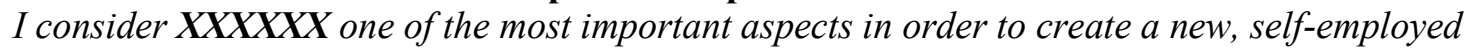
venture or brand.

D01. A great idea or concept

D02. A business model

D03. Personal perseverance, stamina, and confidence

D04. A powerful guan xi network (personal-social network)

D05. Time

D06. A mentor, a business-aiding association, or organization

D07. Business partners

D08. A team (workers, secretaries, assistants, etc.)

D09. Funds, money, and investment

D10. An incubating platform

D11. The optimistic governmental policies

D12. The optimistic socioeconomic environment

D13. Appropriate suppliers (resources, materials, manufacturing, etc.)

D14. The knowledge of economics and business

D15. The knowledge of manufacturing and production

D16. The knowledge of brand development

D17. The knowledge of marketing and e-marketing

D18. The knowledge of entrepreneurship and management 


\section{E - Attitudes about Design Education in China}

E01. The design courses that I took at university have become obsolete.

E02. The required courses that I took at university were very relevant to my major.

E03. The options of elective courses at my university are very rare.

E04. I need to learn more about design research.

E05. I need to learn more about design methods (design thinking, problem-solving, etc.).

E06. I need to learn more about software practices.

E07. I need to learn more about pragmatic design processing in real projects.

E08. I need to learn more about project management.

E09. I need to learn more about marketing and e-marketing.

E10. I need to learn more about business management.

E11. I need to learn more about entrepreneurial management.

E12. I need to learn more about purchasing and selling management.

E13. The educational system at my university is very suitable and qualified for educating young design students.

E14. Current young design graduates have difficulties finding a suitable design job after their graduation.

E15. If current young design graduates could not find a suitable design job after their graduation, they should seek for a non-design job.

E16. If current young design graduates could not find a suitable design job after their graduation, they should be better to start creating their own, self-employed venture or brand.

E17. If current young design graduates could not find a suitable design job after their graduation, they should be better to apply for a postgraduate program or a doctoral program.

\section{F - The Final Question}

F - If you had an opportunity to experience entrepreneurial courses, which courses do you think you would prefer to?

Design-oriented entrepreneurial courses $\quad=1$

Business-oriented entrepreneurial courses $\quad=2$

Design-Business-mixed entrepreneurial courses $\quad=3$

Internet-technological-oriented entrepreneurial courses $=4$ 


\section{Appendix 4. Factor Analysis for Questions in C and D Sets}

KMO and Bartlett's Test

\begin{tabular}{|c|c|c|}
\hline \\
\hline \multicolumn{2}{|c|}{$\begin{array}{l}\text { Kaiser-Meyer-Olkin Measure of Sampling Adequacy. } \\
\text { Bartlett's Test of Sphericity }\end{array}$} & 1383.878 \\
\hline & df & 276 \\
\hline & Sig. & .000 \\
\hline
\end{tabular}

\begin{tabular}{|l|r|r|}
\hline \multicolumn{3}{|c|}{ Communalities } \\
\hline & Initial & Extraction \\
\hline C02 & 1.000 & .570 \\
C03 & 1.000 & .656 \\
C04 & 1.000 & .570 \\
C05 & 1.000 & .708 \\
C06 & 1.000 & .653 \\
C09 & 1.000 & .593 \\
C11 & 1.000 & .600 \\
C12 & 1.000 & .705 \\
C13 & 1.000 & .668 \\
C14 & 1.000 & .759 \\
C15 & 1.000 & .725 \\
C16 & 1.000 & .636 \\
C17 & 1.000 & .691 \\
D01 & 1.000 & .559 \\
D02 & 1.000 & .633 \\
D03 & 1.000 & .588 \\
D05 & 1.000 & .608 \\
D08 & 1.000 & .766 \\
D11 & 1.000 & .661 \\
D14 & 1.000 & .650 \\
D15 & 1.000 & .616 \\
D16 & 1.000 & .786 \\
D17 & 1.000 & .669 \\
D18 & 1.000 & .667 \\
\hline Extaction
\end{tabular}

Extraction Method: Principal Component Analysis. 
Total Variance Explained

\begin{tabular}{|c|c|c|c|c|c|c|c|c|c|}
\hline \multirow[b]{2}{*}{ Component } & \multicolumn{3}{|c|}{ Initial Eigenvalues } & \multicolumn{3}{|c|}{$\begin{array}{c}\text { Extraction Sums of Squared } \\
\text { Loadings }\end{array}$} & \multicolumn{3}{|c|}{ Rotation Sums of Squared Loadings } \\
\hline & Total & $\begin{array}{c}\% \text { of } \\
\text { Variance }\end{array}$ & Cumulative \% & Total & $\begin{array}{c}\% \text { of } \\
\text { Variance }\end{array}$ & Cumulative \% & Total & $\begin{array}{c}\% \text { of } \\
\text { Variance }\end{array}$ & Cumulative $\%$ \\
\hline 1 & 4.397 & 18.321 & 18.321 & 4.397 & 18.321 & 18.321 & 3.513 & 14.638 & 14.638 \\
\hline 2 & 3.163 & 13.179 & 31.500 & 3.163 & 13.179 & 31.500 & 2.494 & 10.392 & 25.030 \\
\hline 3 & 1.902 & 7.924 & 39.424 & 1.902 & 7.924 & 39.424 & 2.061 & 8.589 & 33.620 \\
\hline 4 & 1.585 & 6.603 & 46.026 & 1.585 & 6.603 & 46.026 & 1.760 & 7.335 & 40.954 \\
\hline 5 & 1.380 & 5.752 & 51.778 & 1.380 & 5.752 & 51.778 & 1.608 & 6.701 & 47.655 \\
\hline 6 & 1.257 & 5.239 & 57.017 & 1.257 & 5.239 & 57.017 & 1.506 & 6.273 & 53.928 \\
\hline 7 & 1.039 & 4.330 & 61.347 & 1.039 & 4.330 & 61.347 & 1.459 & 6.078 & 60.006 \\
\hline 8 & 1.015 & 4.227 & 65.575 & 1.015 & 4.227 & 65.575 & 1.336 & 5.569 & 65.575 \\
\hline 9 & .922 & 3.840 & 69.414 & & & & & & \\
\hline 10 & .813 & 3.389 & 72.803 & & & & & & \\
\hline 11 & .723 & 3.014 & 75.817 & & & & & & \\
\hline 12 & .708 & 2.949 & 78.766 & & & & & & \\
\hline 13 & .622 & 2.591 & 81.357 & & & & & & \\
\hline 14 & .571 & 2.378 & 83.734 & & & & & & \\
\hline 15 & 556 & 2316 & 86051 & & & & & & \\
\hline & (50) & 2.510 & 00.031 & & & & & & \\
\hline 16 & .519 & 2.161 & 88.212 & & & & & & \\
\hline 17 & .457 & 1.903 & 90.114 & & & & & & \\
\hline 18 & .444 & 1.851 & 91.965 & & & & & & \\
\hline 19 & .404 & 1.682 & 93.648 & & & & & & \\
\hline 20 & .382 & 1.592 & 95.240 & & & & & & \\
\hline 21 & .346 & 1.440 & 96.680 & & & & & & \\
\hline 22 & 317 & 1.321 & 98.001 & & & & & & \\
\hline & & 1071 & & & & & & & \\
\hline 23 & .257 & 1.071 & 99.072 & & & & & & \\
\hline 24 & .223 & .928 & 100.000 & & & & & & \\
\hline
\end{tabular}

Extraction Method: Principal Component Analysis. 
Rotated Component Matrix ${ }^{a}$

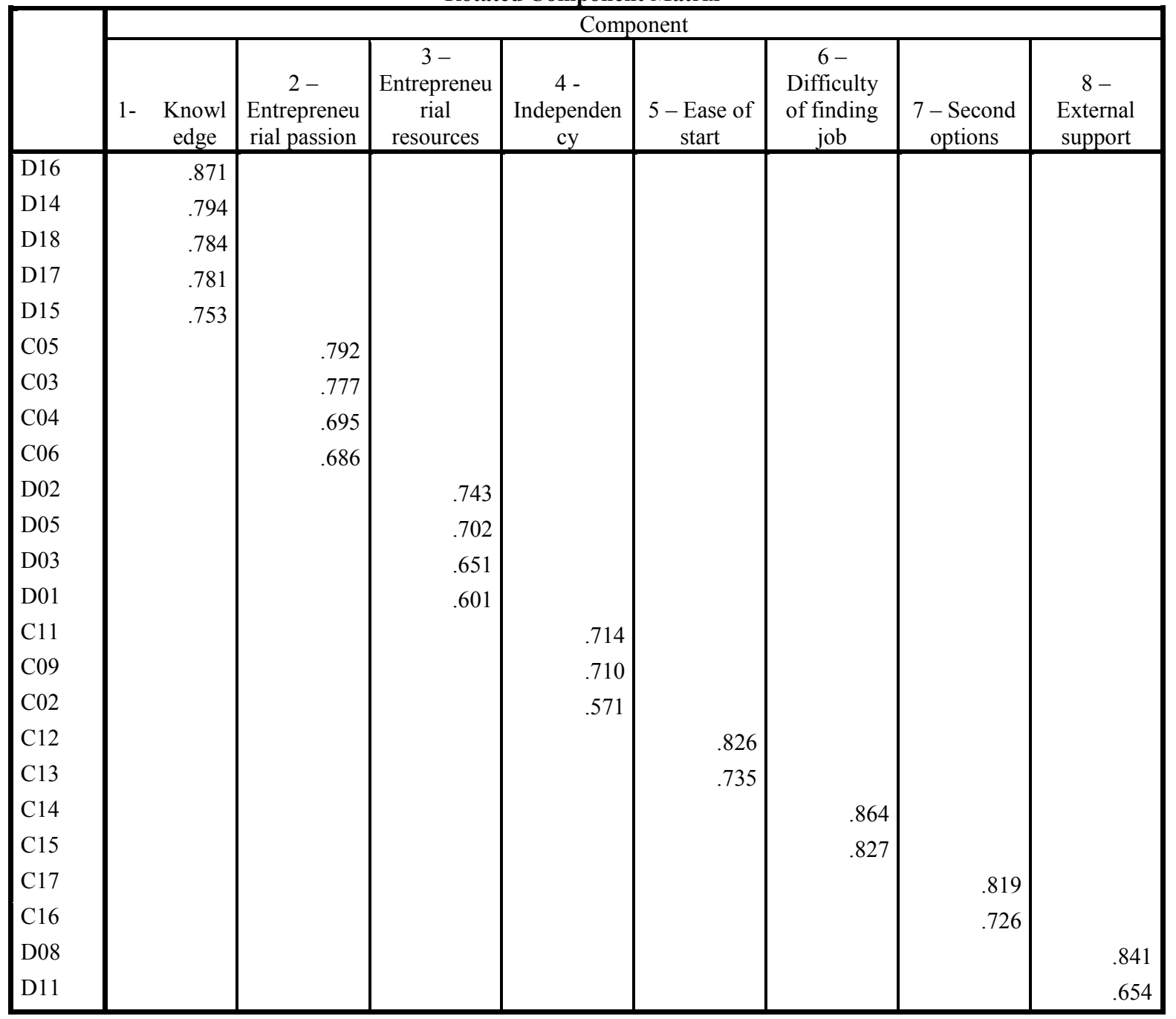

Extraction Method: Principal Component Analysis.

Rotation Method: Varimax with Kaiser Normalization.

a. Rotation converged in 6 iterations.

Component Transformation Matrix

\begin{tabular}{|c|c|c|c|c|c|c|c|c|}
\hline Component & 1 & 2 & 3 & 4 & 5 & 6 & 7 & 8 \\
\hline 1 & .717. & .324 & .454 & .226 & .232 & -.048 & .174 & .193 \\
\hline 2 & -.558 & .657 & .050 & .415 & .192 & -.018 & .205 & -.053 \\
\hline 3 & .083 & .056 & -.366 & -.315 & .359 & .599 & .512 & .087 \\
\hline 4 & -.356 & -.545 & .549 & .063 & .450 & .039 & .152 & .208 \\
\hline 5 & .097 & -.198 & .155 & .491 & -.212 & .587 & -.026 & -.544 \\
\hline 6 & -.172 & .206 & .423 & -.280 & -.597 & .385 & .035 & .407 \\
\hline 7 & .021 & -.063 & -.318 & .439 & .118 & .286 & -.476 & .616 \\
\hline 8 & .032 & -.278 & -.229 & .401 & -.404 & -.253 & .644 & .259 \\
\hline
\end{tabular}

Extraction Method: Principal Component Analysis.

Rotation Method: Varimax with Kaiser Normalization. 


\section{Appendix 5. Cluster Analysis}

Iteration History ${ }^{\mathrm{a}}$

\begin{tabular}{|l|r|r|r|r|r|}
\hline \multirow{2}{*}{ Iteration } & \multicolumn{6}{|c|}{ Change in Cluster Centers } \\
\cline { 2 - 6 } & 1 & 2 & 3 & \multicolumn{1}{c|}{5} \\
\hline 1 & 3.447 & 3.599 & 3.381 & 3.424 & 3.411 \\
2 & .153 & .152 & .247 & .261 & .272 \\
3 & .085 & .237 & .239 & .320 & .218 \\
4 & .112 & .253 & .177 & .284 & .417 \\
5 & .128 & .169 & .173 & .189 & .231 \\
6 & .206 & .198 & .113 & .157 & .173 \\
7 & .078 & .066 & .074 & .114 & .070 \\
8 & .126 & .053 & .093 & .111 & .150 \\
9 & .000 & .000 & .000 & .000 & .000 \\
\hline
\end{tabular}

a. Convergence achieved due to no or small change in cluster centers. The maximum absolute coordinate change for any center is .000 . The current iteration is 9 . The minimum distance between initial centers is 6.229 .

Final Cluster Centers

\begin{tabular}{|c|c|c|c|c|c|}
\hline & \multicolumn{5}{|c|}{ Cluster } \\
\hline & 1 & 2 & 3 & 4 & 5 \\
\hline REGR factor score 1 for analysis 1 & .45081 & -.33396 & .27692 & -1.81963 & .53838 \\
\hline REGR factor score 2 for analysis 1 & -.54057 & -.08331 & .37475 & .40507 & .36505 \\
\hline REGR factor score 3 for analysis 1 & .20140 & -.41230 & -.16953 & 1.01812 & .01525 \\
\hline REGR factor score 4 for analysis 1 & .45462 & -.87926 & .52299 & .44253 & -.15402 \\
\hline REGR factor score 5 for analysis 1 & .46938 & .02744 & -.04175 & -.04755 & -.79534 \\
\hline REGR factor score 6 for analysis 1 & .23053 & .53614 & -.93038 & .02380 & -.16397 \\
\hline REGR factor score 7 for analysis 1 & -.41421 & .46769 & .71999 & -.16806 & -.98481 \\
\hline REGR factor score 8 for analysis 1 & .52857 & -.05550 & -.00740 & .12567 & -.89759 \\
\hline
\end{tabular}

Distances between Final Cluster Centers

\begin{tabular}{|l|r|r|r|r|r|}
\hline Cluster & 1 & 2 & 3 & \multicolumn{1}{c|}{5} \\
\hline 1 & & 2.095 & 2.048 & 2.692 & 2.312 \\
2 & 2.095 & & 2.198 & 2.635 & 2.378 \\
3 & 2.048 & 2.198 & & 2.744 & 2.327 \\
4 & 2.692 & 2.635 & 2.744 & & 3.038 \\
5 & 2.312 & 2.378 & 2.327 & 3.038 & \\
\hline
\end{tabular}


ANOVA

\begin{tabular}{|c|c|c|c|c|c|c|c|}
\hline & & Cluste & & Error & & & \\
\hline & & Mean Square & $\mathrm{df}$ & Mean Square & $\mathrm{df}$ & $\mathrm{F}$ & Sig. \\
\hline $\begin{array}{l}\text { REGR factor score } \\
\text { analysis } 1\end{array}$ & 1 for & 22.067 & 4 & .559 & 191 & 39.489 & .000 \\
\hline $\begin{array}{l}\text { REGR factor score } \\
\text { analysis } 1\end{array}$ & 2 for & 7.109 & 4 & .872 & 191 & 8.153 & .000 \\
\hline $\begin{array}{l}\text { REGR factor score } \\
\text { analysis } 1\end{array}$ & 3 for & 7.829 & 4 & .857 & 191 & 9.135 & .000 \\
\hline $\begin{array}{l}\text { REGR factor score } \\
\text { analysis } 1\end{array}$ & 4 for & 17.163 & 4 & .662 & 191 & 25.945 & .000 \\
\hline $\begin{array}{l}\text { REGR factor score } \\
\text { analysis } 1\end{array}$ & 5 for & 7.701 & 4 & .860 & 191 & 8.959 & .000 \\
\hline $\begin{array}{l}\text { REGR factor score } \\
\text { analysis } 1\end{array}$ & 6 for & 13.517 & 4 & .738 & 191 & 18.319 & .000 \\
\hline $\begin{array}{l}\text { REGR factor score } \\
\text { analysis } 1\end{array}$ & 7 for & 17.866 & 4 & .647 & 191 & 27.622 & .000 \\
\hline $\begin{array}{l}\text { REGR factor score } \\
\text { analysis } 1\end{array}$ & 8 for & 9.858 & 4 & .814 & 191 & 12.104 & .000 \\
\hline
\end{tabular}

Number of Cases in each Cluster

\begin{tabular}{|ll|r|}
\hline Cluster & 1 & 53.000 \\
& 2 \\
& 3 \\
& 4 & 55.000 \\
& 5 & 40.000 \\
& & 18.000 \\
Valid & & 30.000 \\
\hline
\end{tabular}




\section{Appendix 6. Crosstabs Analysis}

$\mathbf{A 0 3} * \mathbf{A 0 1}$

A03 - Type of School * A01 - Gender Crosstabulation

\begin{tabular}{|c|c|c|c|c|c|}
\hline & & & \multicolumn{2}{|c|}{ A01 - Gender } & \multirow[b]{2}{*}{ Total } \\
\hline & & & Male & Female & \\
\hline \multirow[t]{9}{*}{ A03 - Type of School } & 1 tiered & Count & 45 & 47 & 92 \\
\hline & & $\%$ within A03 - Type of School & $48.9 \%$ & $51.1 \%$ & $100.0 \%$ \\
\hline & & $\%$ within $\mathrm{A} 01$ - Gender & $38.8 \%$ & $58.8 \%$ & $46.9 \%$ \\
\hline & 2 tiered & Count & 51 & 24 & 75 \\
\hline & & $\%$ within A03 - Type of School & $68.0 \%$ & $32.0 \%$ & $100.0 \%$ \\
\hline & & $\%$ within A01 - Gender & $44.0 \%$ & $30.0 \%$ & $38.3 \%$ \\
\hline & 3 tiered & Count & 20 & 9 & 29 \\
\hline & & \% within A03 - Type of School & $69.0 \%$ & $31.0 \%$ & $100.0 \%$ \\
\hline & & $\%$ within $\mathrm{A} 01$ - Gender & $17.2 \%$ & $11.3 \%$ & $14.8 \%$ \\
\hline \multirow[t]{3}{*}{ Total } & & Count & 116 & 80 & 196 \\
\hline & & $\%$ within A03 - Type of School & $59.2 \%$ & $40.8 \%$ & $100.0 \%$ \\
\hline & & $\%$ within A01 - Gender & $100.0 \%$ & $100.0 \%$ & $100.0 \%$ \\
\hline
\end{tabular}

Chi-Square Tests

\begin{tabular}{|c|c|c|c|}
\hline & Value & df & $\begin{array}{l}\text { Asymp. Sig. (2- } \\
\text { sided) }\end{array}$ \\
\hline Pearson Chi-Square & $7.579^{\mathrm{a}}$ & 2 & .023 \\
\hline Likelihood Ratio & 7.614 & 2 & .022 \\
\hline Linear-by-Linear Association & 6.170 & 1 & .013 \\
\hline $\mathrm{N}$ of Valid Cases & 196 & & \\
\hline
\end{tabular}

a. 0 cells $(0.0 \%)$ have expected count less than 5 . The minimum expected count is 11.84 .

Symmetric Measures

\begin{tabular}{|ll|r|r|}
\hline & & \multicolumn{1}{|c|}{ Value } & Approx. Sig. \\
\hline Nominal by Nominal & Phi & .197 & .023 \\
& Cramer's V & .197 & .023 \\
N of Valid Cases & & 196 & \\
\hline
\end{tabular}


A05 * A01

\begin{tabular}{|c|c|c|c|c|c|}
\hline & & & \multicolumn{2}{|c|}{ A01 - Gender } & \multirow[b]{2}{*}{ Total } \\
\hline & & & Male & Female & \\
\hline \multirow[t]{15}{*}{ A05 - Education Status } & high & Count & 18 & 7 & 25 \\
\hline & school/diploma/associ & $\%$ within A05 - Education Status & $72.0 \%$ & $28.0 \%$ & $100.0 \%$ \\
\hline & & $\%$ within $\mathrm{A} 01-$ Gender & $15.5 \%$ & $8.8 \%$ & $12.8 \%$ \\
\hline & bachelor degree & Count & 78 & 50 & 128 \\
\hline & & $\%$ within A05 - Education Status & $60.9 \%$ & $39.1 \%$ & $100.0 \%$ \\
\hline & & $\%$ within A01 - Gender & $67.2 \%$ & $62.5 \%$ & $65.3 \%$ \\
\hline & master degree & Count & 16 & 23 & 39 \\
\hline & & $\%$ within A05 - Education Status & $41.0 \%$ & $59.0 \%$ & $100.0 \%$ \\
\hline & & $\%$ within A01 - Gender & $13.8 \%$ & $28.7 \%$ & $19.9 \%$ \\
\hline & $\mathrm{PhD} /$ doctorate degree & Count & 3 & 0 & 3 \\
\hline & & $\%$ within A05 - Education Status & $100.0 \%$ & $0.0 \%$ & $100.0 \%$ \\
\hline & & $\%$ within A01 - Gender & $2.6 \%$ & $0.0 \%$ & $1.5 \%$ \\
\hline & others & Count & 1 & 0 & 1 \\
\hline & & $\%$ within A05 - Education Status & $100.0 \%$ & $0.0 \%$ & $100.0 \%$ \\
\hline & & $\%$ within $\mathrm{A} 01$ - Gender & $0.9 \%$ & $0.0 \%$ & $0.5 \%$ \\
\hline \multirow[t]{3}{*}{ Total } & & Count & 116 & 80 & 196 \\
\hline & & $\%$ within A05 - Education Status & $59.2 \%$ & $40.8 \%$ & $100.0 \%$ \\
\hline & & $\%$ within A01 - Gender & $100.0 \%$ & $100.0 \%$ & $100.0 \%$ \\
\hline
\end{tabular}

Chi-Square Tests

\begin{tabular}{|c|c|c|c|}
\hline & Value & df & $\begin{array}{l}\text { Asymp. Sig. (2- } \\
\text { sided) }\end{array}$ \\
\hline Pearson Chi-Square & $9.945^{\mathrm{a}}$ & 4 & .041 \\
\hline Likelihood Ratio & 11.343 & 4 & .023 \\
\hline Linear-by-Linear Association & 2.188 & 1 & .139 \\
\hline $\mathrm{N}$ of Valid Cases & 196 & & \\
\hline
\end{tabular}

a. 4 cells $(40.0 \%)$ have expected count less than 5 . The minimum expected count is .41 .

Symmetric Measures

\begin{tabular}{|ll|r|r|}
\hline & & \multicolumn{1}{|c|}{ Value } & Approx. Sig. \\
\hline Nominal by Nominal & Phi & .225 & .041 \\
& Cramer's V & .225 & .041 \\
N of Valid Cases & & 196 & \\
\hline
\end{tabular}


A05 - Education Status * F Crosstabulation

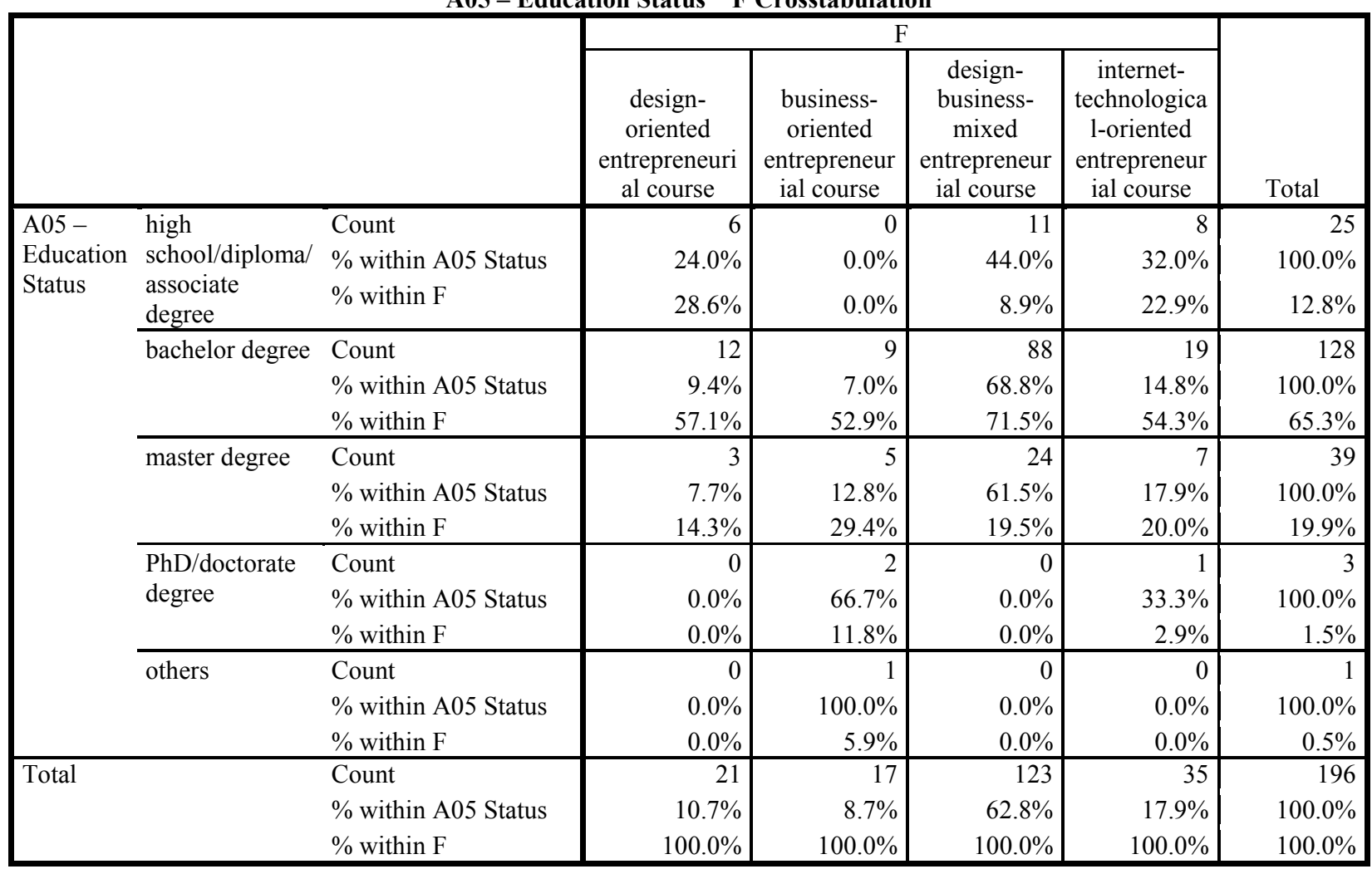

Chi-Square Tests

\begin{tabular}{|l|r|r|r|}
\hline & & & \multicolumn{2}{|c|}{$\begin{array}{c}\text { Asymp. Sig. (2- } \\
\text { sided) }\end{array}$} \\
\hline Pearson Chi-Square & Value & df & .000 \\
Likelihood Ratio & $38.368^{\mathrm{a}}$ & 12 & .005 \\
Linear-by-Linear Association & 28.599 & 12 & .771 \\
N of Valid Cases & .085 & 1 & \\
\hline
\end{tabular}

a. 13 cells $(65.0 \%)$ have expected count less than 5 . The minimum expected count is .09 .

Symmetric Measures

\begin{tabular}{|ll|r|r|}
\hline & & \multicolumn{1}{|c|}{ Value } & \multicolumn{1}{c|}{ Approx. Sig. } \\
\hline Nominal by Nominal & Phi & .442 & .000 \\
& Cramer's V & .255 & .000 \\
N of Valid Cases & & 196 & \\
\hline
\end{tabular}




\section{B01 * A01}

B01 - Are you operating or running your own business or brand now? * A01 - Gender Crosstabulation

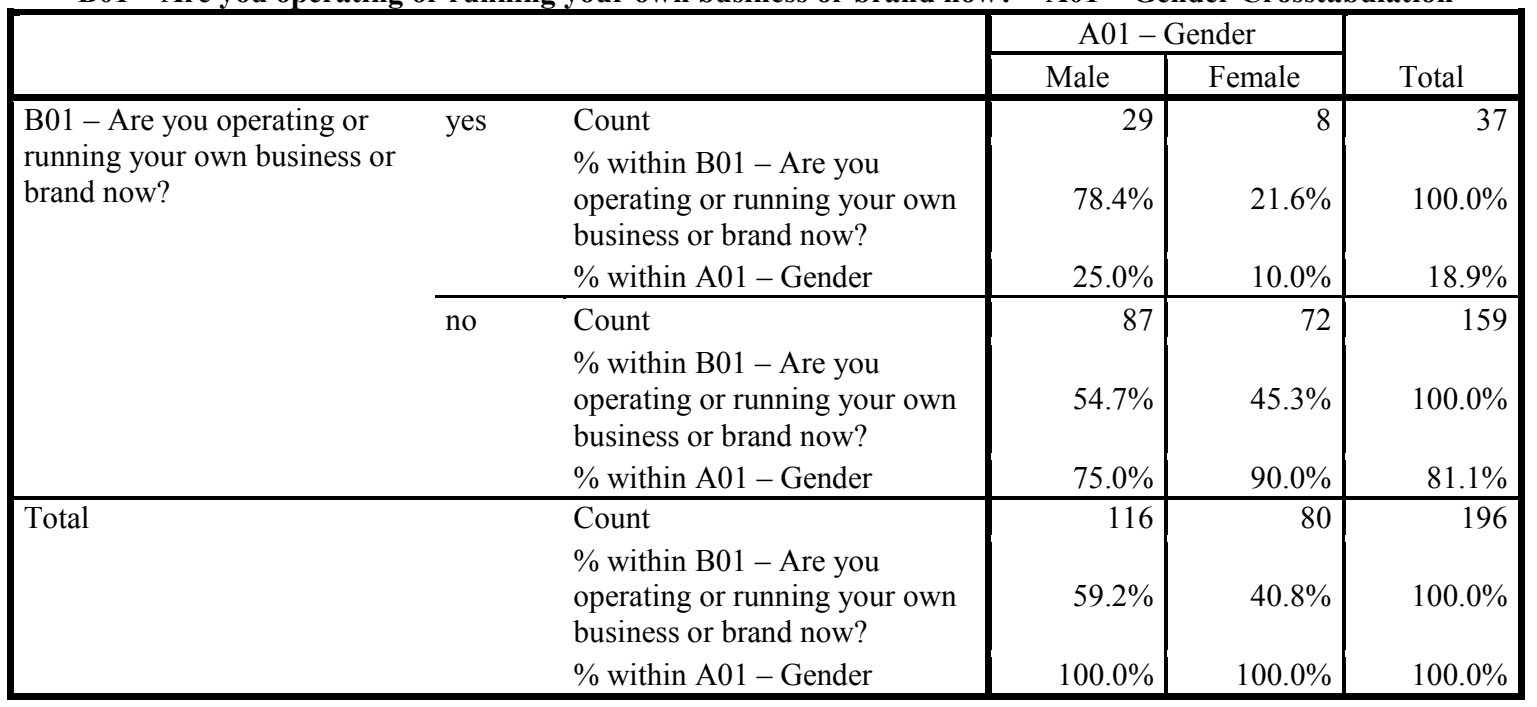

Chi-Square Tests

\begin{tabular}{|c|c|c|c|c|c|}
\hline & Value & $\mathrm{df}$ & $\begin{array}{l}\text { Asymp. Sig. (2- } \\
\text { sided) }\end{array}$ & $\begin{array}{l}\text { Exact Sig. (2- } \\
\text { sided) }\end{array}$ & $\begin{array}{l}\text { Exact Sig. (1- } \\
\text { sided) }\end{array}$ \\
\hline $\begin{array}{l}\text { Pearson Chi-Square } \\
\text { Continuity Correction }^{\text {b }} \\
\text { Likelihood Ratio } \\
\text { Fisher's Exact Test }\end{array}$ & $\begin{array}{r}6.956^{\mathrm{a}} \\
6.011 \\
7.426\end{array}$ & $\begin{array}{l}1 \\
1 \\
1\end{array}$ & $\begin{array}{l}.008 \\
.014 \\
.006\end{array}$ & .009 & .006 \\
\hline $\begin{array}{l}\text { Linear-by-Linear Association } \\
\mathrm{N} \text { of Valid Cases }\end{array}$ & $\begin{array}{r}6.921 \\
196\end{array}$ & 1 & .009 & & \\
\hline
\end{tabular}

a. 0 cells $(0.0 \%)$ have expected count less than 5 . The minimum expected count is 15.10 .

b. Computed only for a $2 \times 2$ table

Symmetric Measures

\begin{tabular}{|ll|r|r|}
\hline & & \multicolumn{1}{|c|}{ Value } & Approx. Sig. \\
\hline Nominal by Nominal & Phi & .188 & .008 \\
& Cramer's V & .188 & .008 \\
N of Valid Cases & & 196 & \\
\hline
\end{tabular}


B01 * A02

B01 - Are you operating or running your own business or brand now? * A02 - Age Crosstabulation

\begin{tabular}{|c|c|c|c|c|c|c|c|}
\hline & & & \multicolumn{4}{|c|}{ A02-Age } & \multirow[b]{2}{*}{ Total } \\
\hline & & & $\begin{array}{c}<23 \text { years } \\
\text { old }\end{array}$ & $\begin{array}{c}\text { 23-26 years } \\
\text { old }\end{array}$ & $\begin{array}{c}27-30 \text { years } \\
\text { old }\end{array}$ & $\begin{array}{c}30>\text { years } \\
\text { old }\end{array}$ & \\
\hline \multirow[t]{3}{*}{$\begin{array}{l}\text { B01 - Are you } \\
\text { operating or running } \\
\text { your own business or } \\
\text { brand now? }\end{array}$} & yes & $\begin{array}{l}\text { Count } \\
\% \text { within B01 - Are } \\
\text { you operating or } \\
\text { running your own } \\
\text { business or brand now? } \\
\% \text { within A02 - Age }\end{array}$ & $\begin{array}{l}8.1 \% \\
9.4 \%\end{array}$ & $\begin{array}{l}29.7 \% \\
12.6 \%\end{array}$ & $\begin{array}{l}13.5 \% \\
11.9 \%\end{array}$ & $\begin{array}{l}48.6 \% \\
51.4 \%\end{array}$ & $\begin{array}{r}100.0 \% \\
18.9 \%\end{array}$ \\
\hline & no & $\begin{array}{l}\text { Count } \\
\% \text { within B01 - Are } \\
\text { you operating or } \\
\text { running your own } \\
\text { business or brand now? }\end{array}$ & $18.2 \%$ & $47.8 \%$ & $23.3 \%$ & $10.7 \%$ & $100.0 \%$ \\
\hline & & $\%$ within A02 - Age & $90.6 \%$ & $87.4 \%$ & $88.1 \%$ & $48.6 \%$ & $81.1 \%$ \\
\hline \multirow[t]{2}{*}{ Total } & & $\begin{array}{l}\text { Count } \\
\% \text { within B01 - Are } \\
\text { you operating or } \\
\text { running your own } \\
\text { business or brand now? }\end{array}$ & $16.3 \%$ & $44.4 \%$ & $21.4 \%$ & $17.9 \%$ & $100.0 \%$ \\
\hline & & $\%$ within A02 - Age & $100.0 \%$ & $100.0 \%$ & $100.0 \%$ & $100.0 \%$ & $100.0 \%$ \\
\hline
\end{tabular}

Chi-Square Tests

\begin{tabular}{|c|c|c|c|}
\hline & Value & $\mathrm{df}$ & $\begin{array}{l}\text { Asymp. Sig. (2- } \\
\text { sided) }\end{array}$ \\
\hline $\begin{array}{l}\text { Pearson Chi-Square } \\
\text { Likelihood Ratio } \\
\text { Linear-by-Linear Association } \\
\mathrm{N} \text { of Valid Cases }\end{array}$ & $\begin{array}{r}29.645^{\mathrm{a}} \\
24.793 \\
18.783 \\
196\end{array}$ & $\begin{array}{l}3 \\
3 \\
1\end{array}$ & $\begin{array}{l}.000 \\
.000 \\
.000\end{array}$ \\
\hline
\end{tabular}

a. 0 cells $(0.0 \%)$ have expected count less than 5 . The minimum expected count is 6.04 .

Symmetric Measures

\begin{tabular}{|ll|r|r|}
\hline & & \multicolumn{1}{|c|}{ Value } & Approx. Sig. \\
\hline Nominal by Nominal & Phi & .389 & .000 \\
& Cramer's V & .389 & .000 \\
N of Valid Cases & & 196 & \\
\hline
\end{tabular}




\section{B01 * A03}

B01 - Are you operating or running your own business or brand now? * A03 - Type of School Crosstabulation

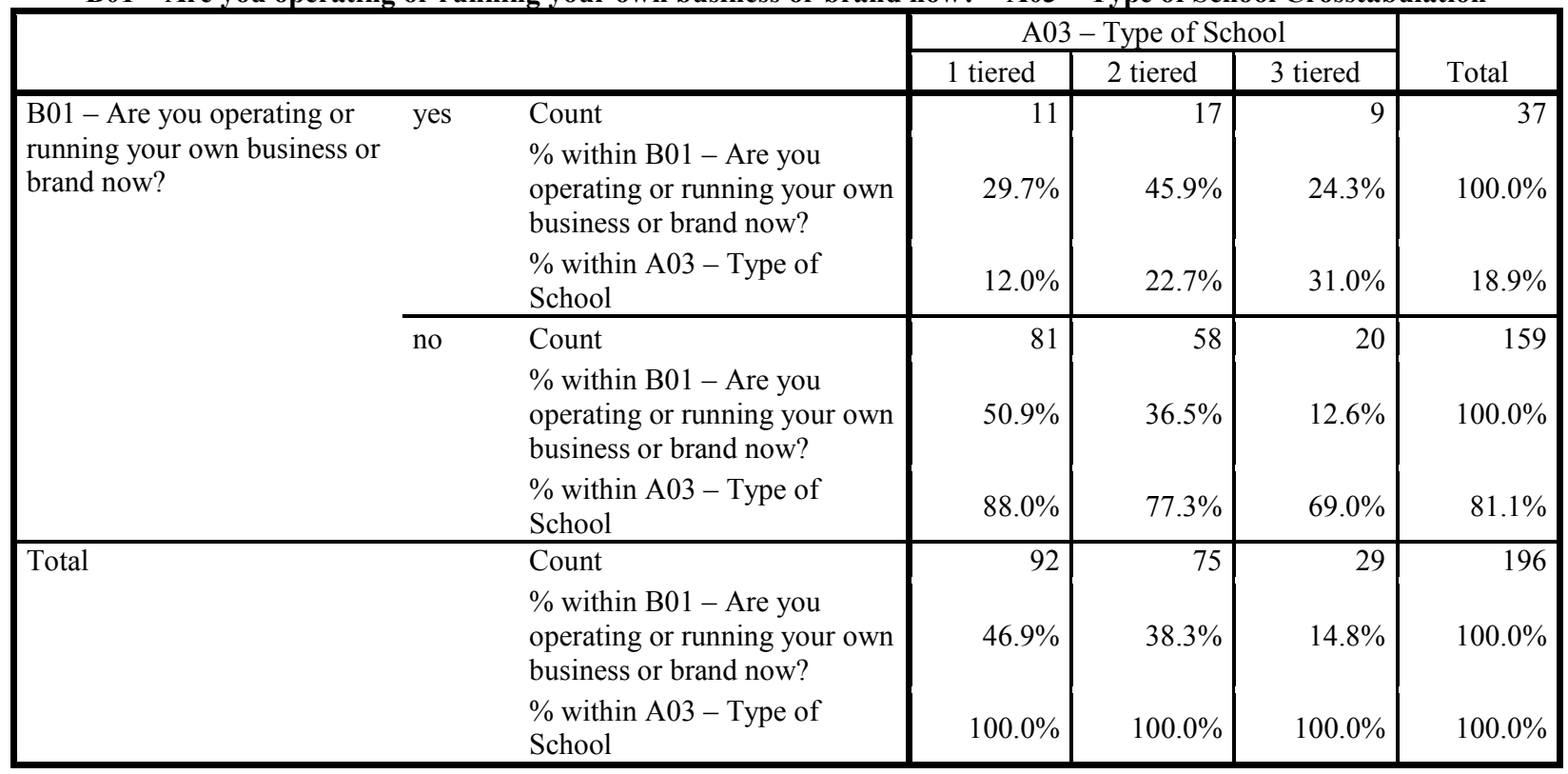

Chi-Square Tests

\begin{tabular}{|l|r|r|r|}
\hline & & & $\begin{array}{c}\text { Asymp. Sig. (2- } \\
\text { sided) }\end{array}$ \\
\hline Pearson Chi-Square & $6.380^{\mathrm{a}}$ & $\mathrm{df}$ & .041 \\
Likelihood Ratio & 6.340 & 2 & .042 \\
Linear-by-Linear Association & 6.311 & 1 & .012 \\
N of Valid Cases & 196 & & \\
\hline
\end{tabular}

a. 0 cells $(0.0 \%)$ have expected count less than 5 . The minimum expected count is 5.47 .

Symmetric Measures

\begin{tabular}{|ll|r|r|}
\hline & & \multicolumn{1}{|c|}{ Value } & Approx. Sig. \\
\hline Nominal by Nominal & Phi & .180 & .041 \\
& Cramer's V & .180 & .041 \\
N of Valid Cases & & 196 & \\
\hline
\end{tabular}




\section{B01 * A05}

B01 - Are you operating or running your own business or brand now? * A05 - Education Status Crosstabulation

\begin{tabular}{|c|c|c|c|c|c|c|c|c|}
\hline & \multicolumn{5}{|c|}{ A05-Education Status } & \multirow[b]{2}{*}{ Total } \\
\hline & & & $\begin{array}{c}\text { high } \\
\text { school/diplom } \\
\text { a/associate } \\
\text { degree }\end{array}$ & $\begin{array}{l}\text { bachelor } \\
\text { degree }\end{array}$ & $\begin{array}{l}\text { master } \\
\text { degree }\end{array}$ & $\begin{array}{c}\mathrm{PhD} / \text { doct } \\
\text { orate } \\
\text { degree }\end{array}$ & others & \\
\hline \multirow[t]{4}{*}{$\begin{array}{l}\text { B01 - Are you } \\
\text { operating or } \\
\text { running your } \\
\text { own business or } \\
\text { brand now? }\end{array}$} & yes & $\begin{array}{l}\text { Count } \\
\% \text { within B } 01 \text { - Are you } \\
\text { operating or running your } \\
\text { own business or brand } \\
\text { now? }\end{array}$ & $24.3 \%$ & $56.8 \%$ & $13.5 \%$ & $2.7 \%$ & $2.7 \%$ & $100.0 \%$ \\
\hline & & $\begin{array}{l}\% \text { within A05 - Education } \\
\text { Status }\end{array}$ & $36.0 \%$ & $16.4 \%$ & $12.8 \%$ & $33.3 \%$ & $100.0 \%$ & $18.9 \%$ \\
\hline & no & $\begin{array}{l}\text { Count } \\
\text { \% within B01 - Are you } \\
\text { operating or running your } \\
\text { own business or brand } \\
\text { now? }\end{array}$ & $10.1 \%$ & $67.3 \%$ & $21.4 \%$ & $1.3 \%$ & $0.0 \%$ & $100.0 \%$ \\
\hline & & $\begin{array}{l}\% \text { within A05 - Education } \\
\text { Status }\end{array}$ & $64.0 \%$ & $83.6 \%$ & $87.2 \%$ & $66.7 \%$ & $0.0 \%$ & $81.1 \%$ \\
\hline \multirow{2}{*}{\multicolumn{2}{|c|}{ Total }} & $\begin{array}{l}\text { Count } \\
\text { \% within B01 - Are you } \\
\text { operating or running your } \\
\text { own business or brand } \\
\text { now? }\end{array}$ & $12.8 \%$ & $65.3 \%$ & $19.9 \%$ & $1.5 \%$ & $0.5 \%$ & $100.0 \%$ \\
\hline & & $\begin{array}{l}\% \text { within A05 - Education } \\
\text { Status }\end{array}$ & $100.0 \%$ & $100.0 \%$ & $100.0 \%$ & $100.0 \%$ & $100.0 \%$ & $100.0 \%$ \\
\hline
\end{tabular}

Chi-Square Tests

\begin{tabular}{|c|c|c|c|}
\hline & Value & $\mathrm{df}$ & $\begin{array}{l}\text { Asymp. Sig. (2- } \\
\text { sided) }\end{array}$ \\
\hline $\begin{array}{l}\text { Pearson Chi-Square } \\
\text { Likelihood Ratio } \\
\text { Linear-by-Linear Association } \\
\mathrm{N} \text { of Valid Cases }\end{array}$ & $\begin{array}{r}10.938^{\mathrm{a}} \\
9.276 \\
.882 \\
196\end{array}$ & $\begin{array}{l}4 \\
4 \\
1\end{array}$ & $\begin{array}{l}.027 \\
.055 \\
.348\end{array}$ \\
\hline
\end{tabular}

a. 5 cells $(50.0 \%)$ have expected count less than 5 . The minimum expected count is .19 .

Symmetric Measures

\begin{tabular}{|ll|r|r|}
\hline & & \multicolumn{1}{|c|}{ Value } & \multicolumn{1}{c|}{ Approx. Sig. } \\
\hline Nominal by Nominal & Phi & .236 & .027 \\
& Cramer's V & .236 & .027 \\
N of Valid Cases & & 196 & \\
\hline
\end{tabular}




\section{B01 * A06}

B01 - Are you operating or running your own business or brand now? * A06 - Type of Company Crosstabulation

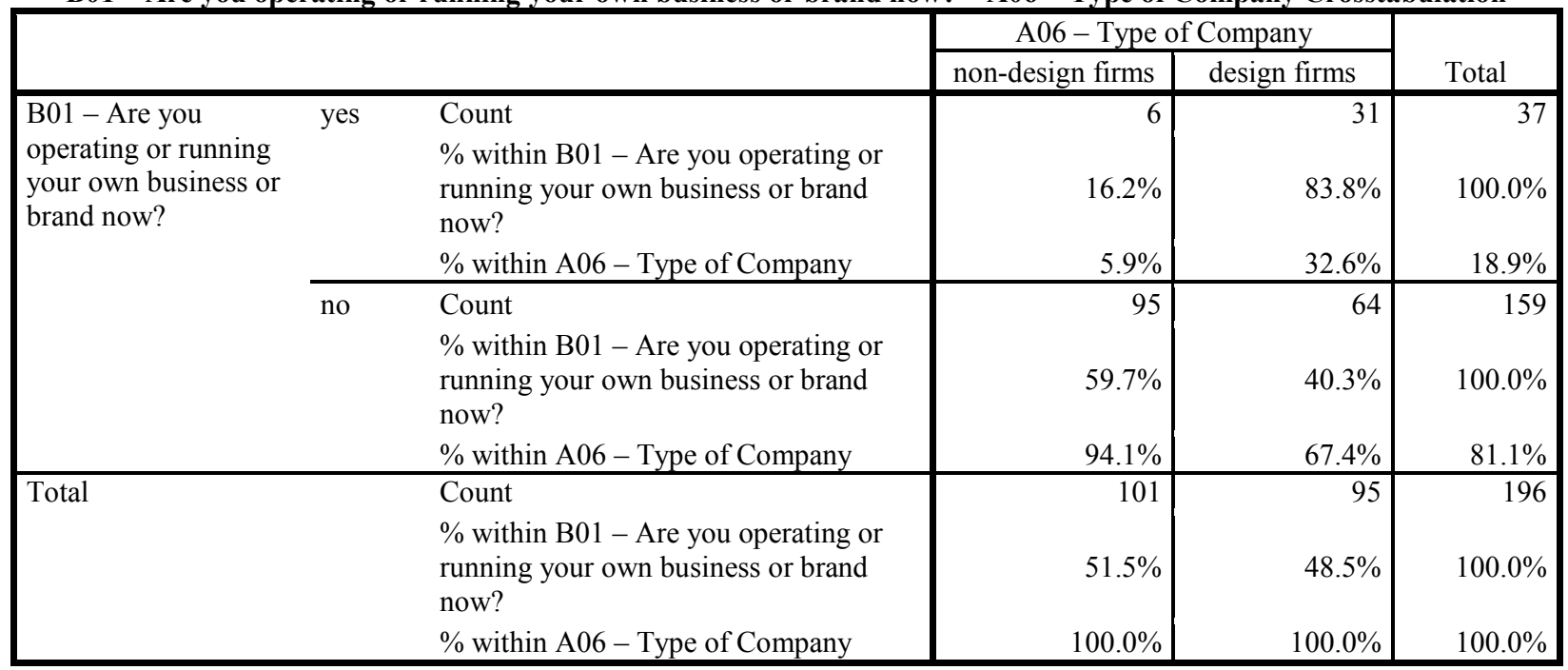

\section{Chi-Square Tests}

\begin{tabular}{|c|c|c|c|c|c|}
\hline & Value & df & $\begin{array}{l}\text { Asymp. Sig. (2- } \\
\text { sided) }\end{array}$ & $\begin{array}{l}\text { Exact Sig. (2- } \\
\text { sided) }\end{array}$ & $\begin{array}{l}\text { Exact Sig. (1- } \\
\text { sided) }\end{array}$ \\
\hline Pearson Chi-Square & $22.774^{\mathrm{a}}$ & 1 & .000 & & \\
\hline Continuity Correction $^{\mathrm{b}}$ & 21.064 & 1 & .000 & & \\
\hline Likelihood Ratio & 24.392 & 1 & .000 & & \\
\hline Fisher's Exact Test & & & & .000 & .000 \\
\hline Linear-by-Linear Association & 22.657 & 1 & .000 & & \\
\hline $\mathrm{N}$ of Valid Cases & 196 & & & & \\
\hline
\end{tabular}

a. 0 cells $(0.0 \%)$ have expected count less than 5 . The minimum expected count is 17.93 .

b. Computed only for a $2 \times 2$ table

Symmetric Measures

\begin{tabular}{|ll|r|r|}
\hline & & \multicolumn{1}{|c|}{ Value } & Approx. Sig. \\
\hline Nominal by Nominal & Phi & -.341 & .000 \\
& Cramer's V & .341 & .000 \\
N of Valid Cases & & 196 & \\
\hline
\end{tabular}




\section{B01 * A09}

B01 - Are you operating or running your own business or brand now? * A09 - Years of Working Crosstabulation

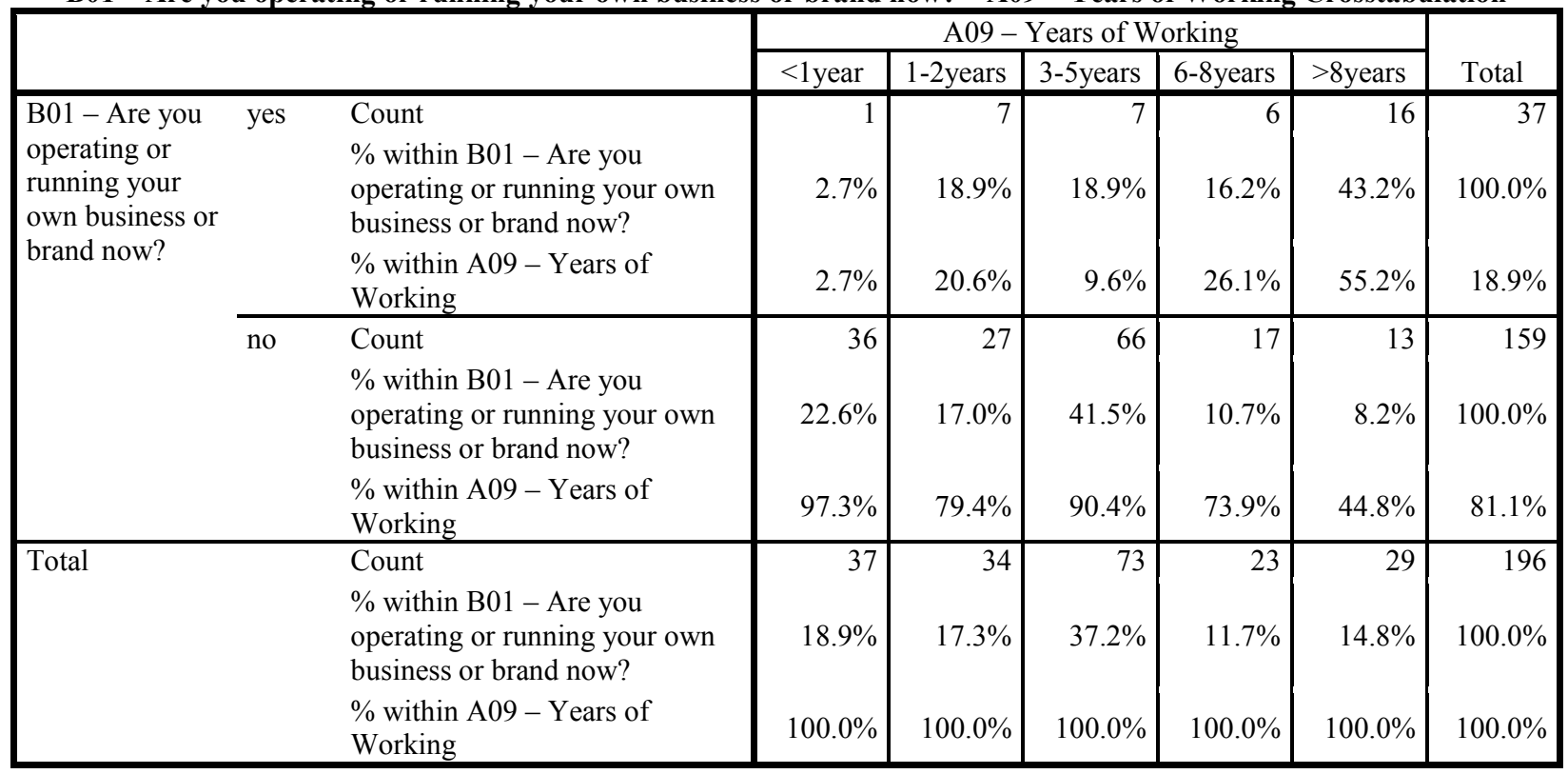

\section{Chi-Square Tests}

\begin{tabular}{|l|r|r|r|}
\hline & & & \multicolumn{2}{|c|}{$\begin{array}{c}\text { Asymp. Sig. (2- } \\
\text { sided) }\end{array}$} \\
\hline Pearson Chi-Square & Value & df & .000 \\
Likelihood Ratio & $36.225^{\mathrm{a}}$ & 4 & .000 \\
Linear-by-Linear Association & 23.708 & 4 & .000 \\
N of Valid Cases & 196 & 1 & \\
\hline
\end{tabular}

a. 1 cells $(10.0 \%)$ have expected count less than 5 . The minimum expected count is 4.34 .

Symmetric Measures

\begin{tabular}{|ll|r|r|}
\hline & & \multicolumn{1}{|c|}{ Value } & Approx. Sig. \\
\hline Nominal by Nominal & Phi & .430 & .000 \\
& Cramer's V & .430 & .000 \\
N of Valid Cases & & 196 & \\
\hline
\end{tabular}




\section{B03 * A01}

B03 - Which one is the most appealing category for you if you were to start your own venture? * A01 - Gender Crosstabulation

\begin{tabular}{|c|c|c|c|c|c|}
\hline & & & \multicolumn{2}{|c|}{ A01-Gender } & \multirow[b]{2}{*}{ Total } \\
\hline & & & Male & Female & \\
\hline \multirow{24}{*}{$\begin{array}{l}\text { B03 - Which one is } \\
\text { the most appealing } \\
\text { category for you if } \\
\text { you were to start } \\
\text { your own venture? }\end{array}$} & \multirow[t]{3}{*}{0} & Count & 5 & 8 & 13 \\
\hline & & \% within B03 & $38.5 \%$ & $61.5 \%$ & $100.0 \%$ \\
\hline & & $\%$ within A01 - Gender & $4.3 \%$ & $10.0 \%$ & $6.6 \%$ \\
\hline & \multirow[t]{3}{*}{ design firms } & Count & 25 & 15 & 40 \\
\hline & & \% within B03 & $62.5 \%$ & $37.5 \%$ & $100.0 \%$ \\
\hline & & $\%$ within A01 - Gender & $21.6 \%$ & $18.8 \%$ & $20.4 \%$ \\
\hline & \multirow{3}{*}{$\begin{array}{l}\text { brands in crafts and } \\
\text { products }\end{array}$} & Count & 23 & 22 & 45 \\
\hline & & $\%$ within B03 & $51.1 \%$ & $48.9 \%$ & $100.0 \%$ \\
\hline & & $\%$ within A01 - Gender & $19.8 \%$ & $27.5 \%$ & $23.0 \%$ \\
\hline & \multirow{3}{*}{$\begin{array}{l}\text { IT products, digital } \\
\text { devices, etc. }\end{array}$} & Count & 25 & 6 & 31 \\
\hline & & \% within B03 & $80.6 \%$ & $19.4 \%$ & $100.0 \%$ \\
\hline & & $\%$ within A01 - Gender & $21.6 \%$ & $7.5 \%$ & $15.8 \%$ \\
\hline & \multirow{3}{*}{$\begin{array}{l}\text { clothes, garments, bags, } \\
\text { etc. }\end{array}$} & Count & 4 & 5 & 9 \\
\hline & & $\%$ within B03 & $44.4 \%$ & $55.6 \%$ & $100.0 \%$ \\
\hline & & $\%$ within A01 - Gender & $3.4 \%$ & $6.3 \%$ & $4.6 \%$ \\
\hline & \multirow{3}{*}{$\begin{array}{l}\text { internet technology and } \\
\text { gaming }\end{array}$} & Count & 23 & 12 & 35 \\
\hline & & $\%$ within B03 & $65.7 \%$ & $34.3 \%$ & $100.0 \%$ \\
\hline & & $\%$ within A01 - Gender & $19.8 \%$ & $15.0 \%$ & $17.9 \%$ \\
\hline & \multirow[t]{3}{*}{ media and photography } & Count & 5 & 9 & 14 \\
\hline & & \% within B03 & $35.7 \%$ & $64.3 \%$ & $100.0 \%$ \\
\hline & & $\%$ within A01 - Gender & $4.3 \%$ & $11.3 \%$ & $7.1 \%$ \\
\hline & \multirow{3}{*}{$\begin{array}{l}\text { design education and } \\
\text { training }\end{array}$} & Count & 6 & 3 & 9 \\
\hline & & \% within B03 & $66.7 \%$ & $33.3 \%$ & $100.0 \%$ \\
\hline & & $\%$ within A01 - Gender & $5.2 \%$ & $3.8 \%$ & $4.6 \%$ \\
\hline \multirow{3}{*}{\multicolumn{2}{|c|}{ Total }} & Count & 116 & 80 & 196 \\
\hline & & \% within B03 & $59.2 \%$ & $40.8 \%$ & $100.0 \%$ \\
\hline & & $\%$ within A01 - Gender & $100.0 \%$ & $100.0 \%$ & $100.0 \%$ \\
\hline
\end{tabular}

Chi-Square Tests

\begin{tabular}{|l|r|r|r|}
\hline & & & \multicolumn{2}{|c|}{$\begin{array}{c}\text { Asymp. Sig. (2- } \\
\text { sided) }\end{array}$} \\
\hline Pearson Chi-Square & Value & df & .044 \\
Likelihood Ratio & $14.446^{\mathrm{a}}$ & 7 & .037 \\
Linear-by-Linear Association & 14.917 & 7 & .701 \\
N of Valid Cases & .147 & 1 & \\
\hline
\end{tabular}

a. 2 cells $(12.5 \%)$ have expected count less than 5 . The minimum expected count is 3.67 .

Symmetric Measures

\begin{tabular}{|ll|r|r|}
\hline & & \multicolumn{1}{|c|}{ Value } & Approx. Sig. \\
\hline Nominal by Nominal & Phi & .271 & .044 \\
& Cramer's V & .271 & .044 \\
N of Valid Cases & & 196 & \\
\hline
\end{tabular}




\section{B04 * A02}

B04 - What is the likelihood of creating your own venture? * A02 - Age Crosstabulation

\begin{tabular}{|c|c|c|c|c|c|c|c|}
\hline & & & \multicolumn{4}{|c|}{ A02-Age } & \multirow[b]{2}{*}{ Total } \\
\hline & & & $\begin{array}{c}<23 \text { years } \\
\text { old }\end{array}$ & $\begin{array}{c}23-26 \\
\text { years old }\end{array}$ & $\begin{array}{c}27-30 \\
\text { years old }\end{array}$ & $\begin{array}{c}30>\text { years } \\
\text { old }\end{array}$ & \\
\hline \multirow{21}{*}{$\begin{array}{l}\text { B04 - What is the } \\
\text { likelihood of } \\
\text { creating your own } \\
\text { venture? }\end{array}$} & \multirow{3}{*}{$\begin{array}{l}0=\text { Do not want } \\
\text { to start any } \\
\text { business }\end{array}$} & Count & 5 & 15 & 10 & 20 & 50 \\
\hline & & \% within B04 & $10.0 \%$ & $30.0 \%$ & $20.0 \%$ & $40.0 \%$ & $100.0 \%$ \\
\hline & & $\%$ within $\mathrm{A} 02-\mathrm{Age}$ & $15.6 \%$ & $17.2 \%$ & $23.8 \%$ & $57.1 \%$ & $25.5 \%$ \\
\hline & \multirow[t]{3}{*}{ very soon } & Count & 0 & 1 & 1 & 0 & 2 \\
\hline & & $\%$ within B04 & $0.0 \%$ & $50.0 \%$ & $50.0 \%$ & $0.0 \%$ & $100.0 \%$ \\
\hline & & $\%$ within $\mathrm{A} 02-\mathrm{Age}$ & $0.0 \%$ & $1.1 \%$ & $2.4 \%$ & $0.0 \%$ & $1.0 \%$ \\
\hline & \multirow[t]{3}{*}{ in 6-12 months } & Count & 0 & 2 & 1 & 1 & 4 \\
\hline & & \% within B04 & $0.0 \%$ & $50.0 \%$ & $25.0 \%$ & $25.0 \%$ & $100.0 \%$ \\
\hline & & $\%$ within A02 - Age & $0.0 \%$ & $2.3 \%$ & $2.4 \%$ & $2.9 \%$ & $2.0 \%$ \\
\hline & \multirow[t]{3}{*}{ in $1-2$ years } & Count & 1 & 5 & 6 & 6 & 18 \\
\hline & & $\%$ within B04 & $5.6 \%$ & $27.8 \%$ & $33.3 \%$ & $33.3 \%$ & $100.0 \%$ \\
\hline & & $\%$ within $\mathrm{A} 02-\mathrm{Age}$ & $3.1 \%$ & $5.7 \%$ & $14.3 \%$ & $17.1 \%$ & $9.2 \%$ \\
\hline & \multirow[t]{3}{*}{ in $2-3$ years } & Count & 3 & 12 & 7 & 1 & 23 \\
\hline & & \% within B04 & $13.0 \%$ & $52.2 \%$ & $30.4 \%$ & $4.3 \%$ & $100.0 \%$ \\
\hline & & $\%$ within A02-Age & $9.4 \%$ & $13.8 \%$ & $16.7 \%$ & $2.9 \%$ & $11.7 \%$ \\
\hline & \multirow[t]{3}{*}{ in $3-5$ years } & Count & 9 & 25 & 9 & 5 & 48 \\
\hline & & \% within B04 & $18.8 \%$ & $52.1 \%$ & $18.8 \%$ & $10.4 \%$ & $100.0 \%$ \\
\hline & & $\%$ within A02 - Age & $28.1 \%$ & $28.7 \%$ & $21.4 \%$ & $14.3 \%$ & $24.5 \%$ \\
\hline & \multirow[t]{3}{*}{5 years later } & Count & 14 & 27 & 8 & 2 & 51 \\
\hline & & $\%$ within B04 & $27.5 \%$ & $52.9 \%$ & $15.7 \%$ & $3.9 \%$ & $100.0 \%$ \\
\hline & & $\%$ within A02-Age & $43.8 \%$ & $31.0 \%$ & $19.0 \%$ & $5.7 \%$ & $26.0 \%$ \\
\hline \multirow{3}{*}{\multicolumn{2}{|c|}{ Total }} & Count & 32 & 87 & 42 & 35 & 196 \\
\hline & & \% within B04? & $16.3 \%$ & $44.4 \%$ & $21.4 \%$ & $17.9 \%$ & $100.0 \%$ \\
\hline & & $\%$ within $\mathrm{A} 02-\mathrm{Age}$ & $100.0 \%$ & $100.0 \%$ & $100.0 \%$ & $100.0 \%$ & $100.0 \%$ \\
\hline
\end{tabular}

Chi-Square Tests

\begin{tabular}{|l|r|r|r|}
\hline & & & \multicolumn{2}{|c|}{$\begin{array}{c}\text { Asymp. Sig. (2- } \\
\text { sided) }\end{array}$} \\
\hline Pearson Chi-Square & $42.802^{\mathrm{a}}$ & 18 & .001 \\
Likelihood Ratio & 43.883 & 18 & .001 \\
Linear-by-Linear Association & 27.877 & 1 & .000 \\
N of Valid Cases & 196 & & \\
\hline
\end{tabular}

a. 14 cells $(50.0 \%)$ have expected count less than 5 . The minimum expected count is .33 .

Symmetric Measures

\begin{tabular}{|ll|r|r|}
\hline & & \multicolumn{1}{|c|}{ Value } & Approx. Sig. \\
\hline Nominal by Nominal & Phi & .467 & .001 \\
& Cramer's V & .270 & .001 \\
N of Valid Cases & & 196 & \\
\hline
\end{tabular}




\section{B04 * A06}

B04 - What is the likelihood of creating your own venture? * A06 - Type of Company Crosstabulation

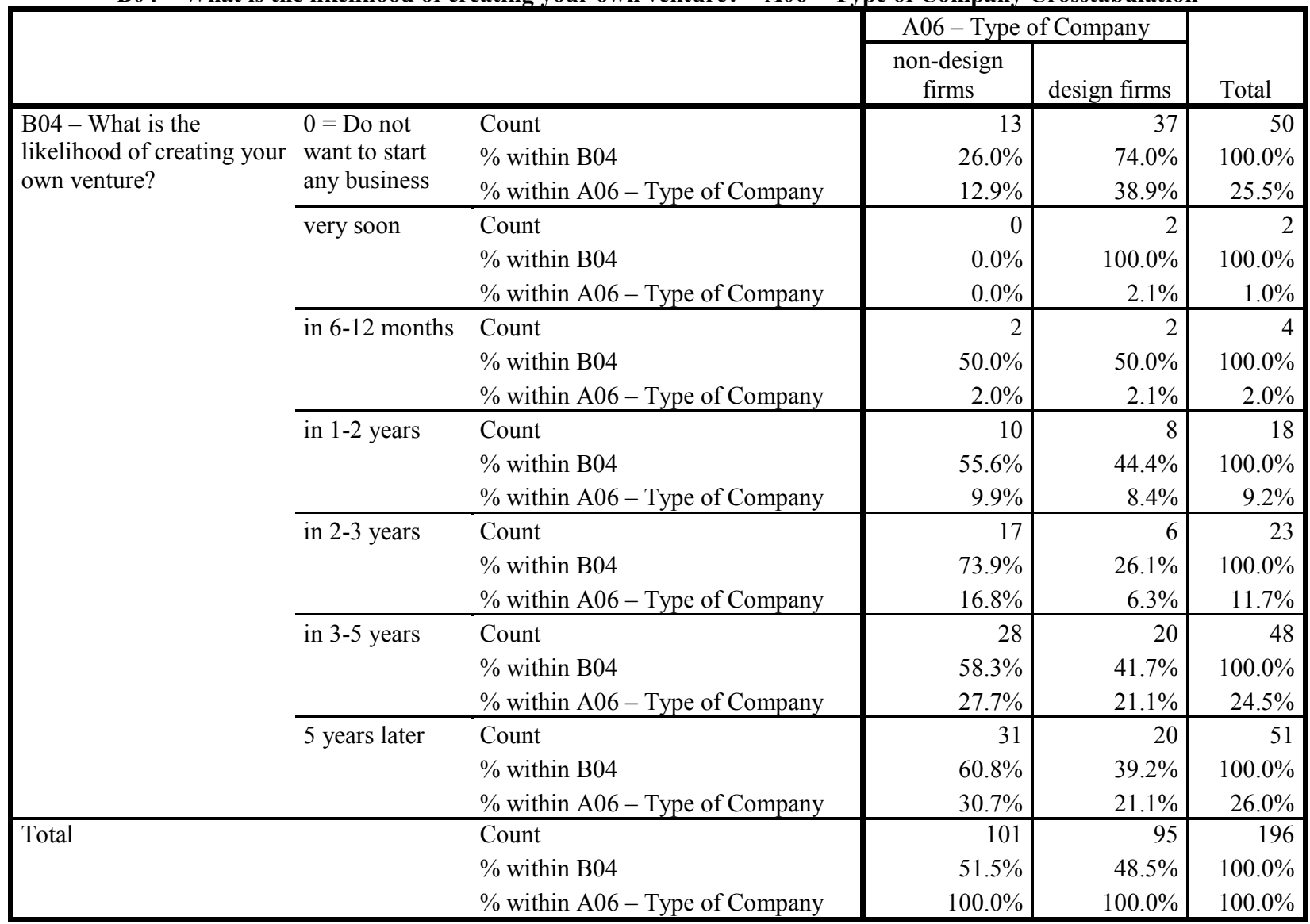

Chi-Square Tests

\begin{tabular}{|c|c|c|c|}
\hline & Value & df & $\begin{array}{l}\text { Asymp. Sig. (2- } \\
\text { sided) }\end{array}$ \\
\hline $\begin{array}{l}\text { Pearson Chi-Square } \\
\text { Likelihood Ratio } \\
\text { Linear-by-Linear Association } \\
\mathrm{N} \text { of Valid Cases }\end{array}$ & $\begin{array}{r}22.546^{\mathrm{a}} \\
24.034 \\
16.347 \\
196\end{array}$ & $\begin{array}{l}6 \\
6 \\
1\end{array}$ & $\begin{array}{l}.001 \\
.001 \\
.000\end{array}$ \\
\hline
\end{tabular}

a. 4 cells $(28.6 \%)$ have expected count less than 5 . The minimum expected count is .97 .

Symmetric Measures

\begin{tabular}{|ll|r|r|}
\hline & & \multicolumn{1}{|c|}{ Value } & Approx. Sig. \\
\hline Nominal by Nominal & Phi & .339 & .001 \\
& Cramer's V & .339 & .001 \\
N of Valid Cases & & 196 & \\
\hline
\end{tabular}




\section{B04 * A09}

B04 - What is the likelihood of creating your own venture? * A09 - Years of Working Crosstabulation

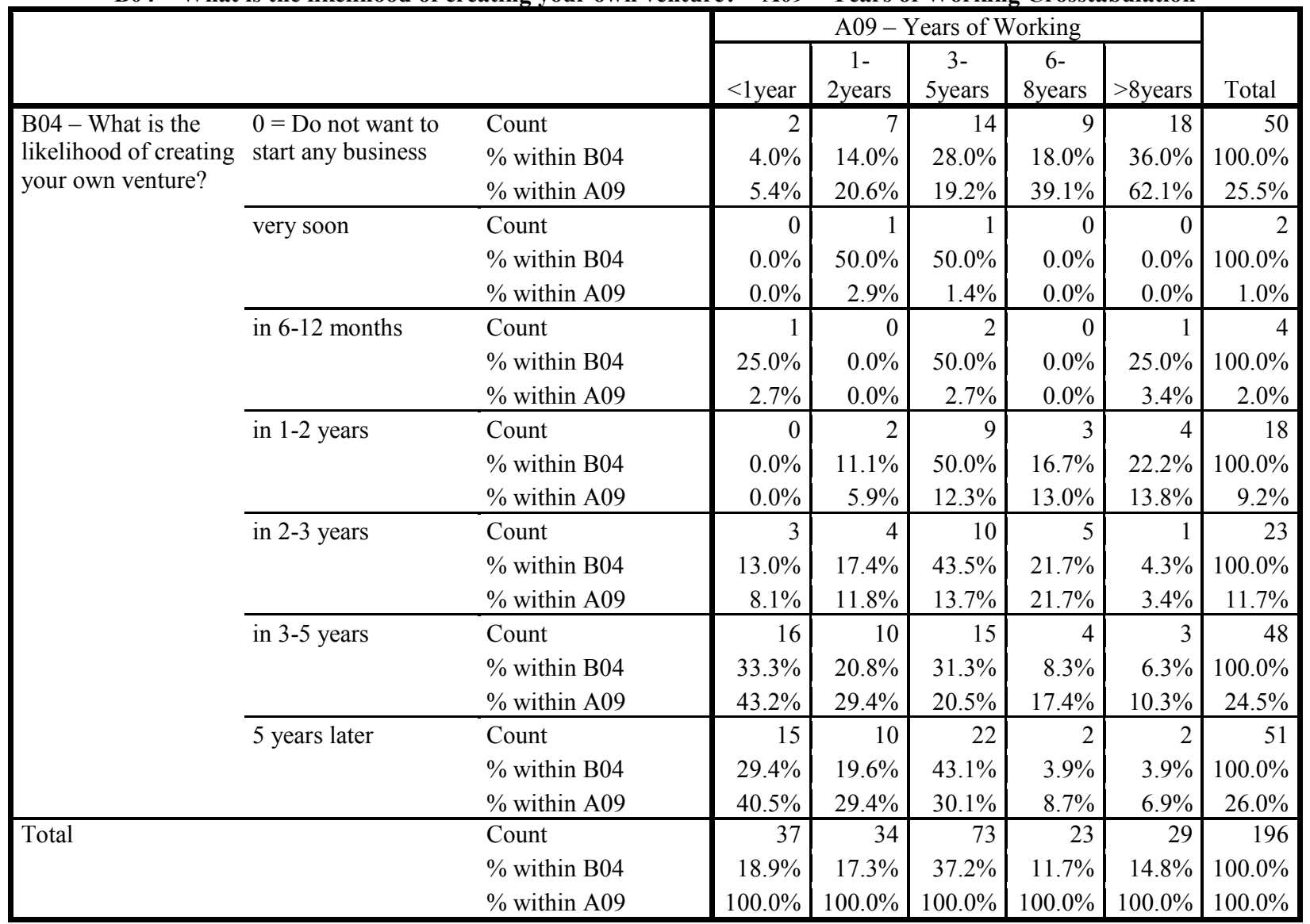

Chi-Square Tests

\begin{tabular}{|l|r|r|r|}
\hline & & & \multicolumn{2}{|c|}{$\begin{array}{c}\text { Asymp. Sig. (2- } \\
\text { sided) }\end{array}$} \\
\hline Pearson Chi-Square & $57.376^{\mathrm{a}}$ & $\mathrm{df}$ & .000 \\
Likelihood Ratio & 62.705 & 24 & .000 \\
Linear-by-Linear Association & 36.863 & 1 & .000 \\
N of Valid Cases & 196 & & \\
\hline
\end{tabular}

a. 18 cells $(51.4 \%)$ have expected count less than 5 . The minimum expected count is .23 .

Symmetric Measures

\begin{tabular}{|ll|r|r|}
\hline & & \multicolumn{1}{|c|}{ Value } & Approx. Sig. \\
\hline Nominal by Nominal & Phi & .541 & .000 \\
& Cramer's V & .271 & .000 \\
N of Valid Cases & & 196 & \\
\hline
\end{tabular}




\section{B04 * Clusters}

B04 - What is the likelihood of creating your own venture? * Cluster Number of Case Crosstabulation

\begin{tabular}{|c|c|c|c|c|c|c|c|c|}
\hline & & & & Cluster & Number & f Case & & \\
\hline & & & 1 & 2 & 3 & 4 & 5 & Total \\
\hline B04-What is the & $0=$ Do not want to & Count & 13 & 13 & 8 & 6 & 10 & 50 \\
\hline likelihood of creating & start any business & \% within B04 & $26.0 \%$ & $26.0 \%$ & $16.0 \%$ & $12.0 \%$ & $20.0 \%$ & $100.0 \%$ \\
\hline & & $\%$ within Cluster & $24.5 \%$ & $23.6 \%$ & $20.0 \%$ & $33.3 \%$ & $33.3 \%$ & $25.5 \%$ \\
\hline & very soon & Count & 0 & 1 & 1 & 0 & 0 & 2 \\
\hline & & $\%$ within B04 & $0.0 \%$ & $50.0 \%$ & $50.0 \%$ & $0.0 \%$ & $0.0 \%$ & $100.0 \%$ \\
\hline & & $\%$ within Cluster & $0.0 \%$ & $1.8 \%$ & $2.5 \%$ & $0.0 \%$ & $0.0 \%$ & $1.0 \%$ \\
\hline & in 6-12 months & Count & 1 & 1 & 0 & 0 & 2 & 4 \\
\hline & & \% within B04 & $25.0 \%$ & $25.0 \%$ & $0.0 \%$ & $0.0 \%$ & $50.0 \%$ & $100.0 \%$ \\
\hline & & $\%$ within Cluster & $1.9 \%$ & $1.8 \%$ & $0.0 \%$ & $0.0 \%$ & $6.7 \%$ & $2.0 \%$ \\
\hline & in $1-2$ years & Count & 3 & 3 & 2 & 6 & 4 & 18 \\
\hline & & $\%$ within B04 & $16.7 \%$ & $16.7 \%$ & $11.1 \%$ & $33.3 \%$ & $22.2 \%$ & $100.0 \%$ \\
\hline & & $\%$ within Cluster & $5.7 \%$ & $5.5 \%$ & $5.0 \%$ & $33.3 \%$ & $13.3 \%$ & $9.2 \%$ \\
\hline & in $2-3$ years & Count & 6 & 3 & 11 & 1 & 2 & 23 \\
\hline & & \% within B04 & $26.1 \%$ & $13.0 \%$ & $47.8 \%$ & $4.3 \%$ & $8.7 \%$ & $100.0 \%$ \\
\hline & & $\%$ within Cluster & $11.3 \%$ & $5.5 \%$ & $27.5 \%$ & $5.6 \%$ & $6.7 \%$ & $11.7 \%$ \\
\hline & in $3-5$ years & Count & 11 & 18 & 10 & 4 & 5 & 48 \\
\hline & & \% within B04 & $22.9 \%$ & $37.5 \%$ & $20.8 \%$ & $8.3 \%$ & $10.4 \%$ & $100.0 \%$ \\
\hline & & $\%$ within Cluster & $20.8 \%$ & $32.7 \%$ & $25.0 \%$ & $22.2 \%$ & $16.7 \%$ & $24.5 \%$ \\
\hline & 5 years later & Count & 19 & 16 & 8 & 1 & 7 & 51 \\
\hline & & $\%$ within B04 & $37.3 \%$ & $31.4 \%$ & $15.7 \%$ & $2.0 \%$ & $13.7 \%$ & $100.0 \%$ \\
\hline & & $\%$ within Cluster & $35.8 \%$ & $29.1 \%$ & $20.0 \%$ & $5.6 \%$ & $23.3 \%$ & $26.0 \%$ \\
\hline Total & & Count & 53 & 55 & 40 & 18 & 30 & 196 \\
\hline & & \% within B04 & $27.0 \%$ & $28.1 \%$ & $20.4 \%$ & $9.2 \%$ & $15.3 \%$ & $100.0 \%$ \\
\hline & & $\%$ within Cluster & $100.0 \%$ & $100.0 \%$ & $100.0 \%$ & $100.0 \%$ & $100.0 \%$ & $100.0 \%$ \\
\hline
\end{tabular}

Chi-Square Tests

\begin{tabular}{|l|r|r|r|}
\hline & & & \multicolumn{2}{|c|}{$\begin{array}{c}\text { Asymp. Sig. (2- } \\
\text { sided) }\end{array}$} \\
\hline Pearson Chi-Square & Value & df & .011 \\
Likelihood Ratio & $42.502^{\mathrm{a}}$ & 24 & .032 \\
Linear-by-Linear Association & 38.404 & 24 & .044 \\
N of Valid Cases & 4.057 & 1 & \\
\hline
\end{tabular}

a. 20 cells $(57.1 \%)$ have expected count less than 5 . The minimum expected count is .18 .

Symmetric Measures

\begin{tabular}{|ll|r|r|}
\hline & & \multicolumn{1}{|c|}{ Value } & Approx. Sig. \\
\hline Nominal by Nominal & Phi & .466 & .011 \\
& Cramer's V & .233 & .011 \\
N of Valid Cases & & 196 & \\
\hline
\end{tabular}




\section{E01 * A01}

E01 * A01 - Gender Crosstabulation

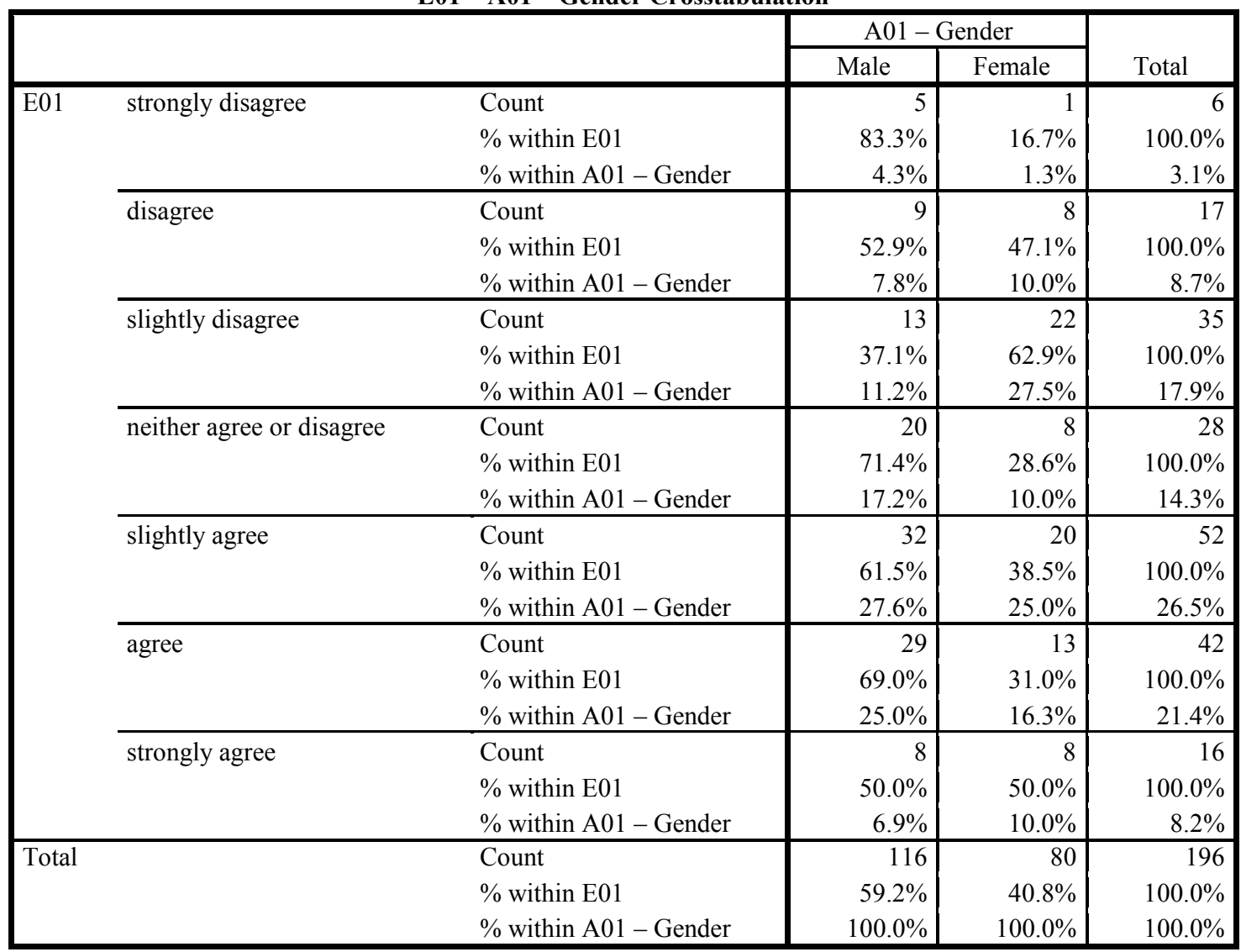

Chi-Square Tests

\begin{tabular}{|c|c|c|c|}
\hline & Value & $\mathrm{df}$ & $\begin{array}{l}\text { Asymp. Sig. (2- } \\
\text { sided) }\end{array}$ \\
\hline $\begin{array}{l}\text { Pearson Chi-Square } \\
\text { Likelihood Ratio } \\
\text { Linear-by-Linear Association } \\
\mathrm{N} \text { of Valid Cases }\end{array}$ & $\begin{array}{r}12.869^{\mathrm{a}} \\
13.020 \\
.977 \\
196\end{array}$ & $\begin{array}{l}6 \\
6 \\
1\end{array}$ & $\begin{array}{l}.045 \\
.043 \\
.323\end{array}$ \\
\hline
\end{tabular}

a. 2 cells $(14.3 \%)$ have expected count less than 5 . The minimum expected count is 2.45 .

Symmetric Measures

\begin{tabular}{|ll|r|r|}
\hline & & \multicolumn{1}{|c|}{ Value } & Approx. Sig. \\
\hline Nominal by Nominal & Phi & .256 & .045 \\
& Cramer's V & .256 & .045 \\
N of Valid Cases & & 196 & \\
\hline
\end{tabular}




\section{E01 * A04}

E01 * A04 - Type of Student Crosstabulation

\begin{tabular}{|c|c|c|c|c|c|}
\hline & & & \multicolumn{2}{|c|}{ A04 - Type of Student } & \multirow[b]{2}{*}{ Total } \\
\hline & & & $\begin{array}{c}\text { arts and } \\
\text { humanities }\end{array}$ & $\begin{array}{l}\text { science and } \\
\text { engineering }\end{array}$ & \\
\hline \multirow[t]{21}{*}{ E01 } & \multirow[t]{3}{*}{ strongly disagree } & Count & 3 & 3 & 6 \\
\hline & & \% within E01 & $50.0 \%$ & $50.0 \%$ & $100.0 \%$ \\
\hline & & $\%$ within A04 - Type of Student & $2.3 \%$ & $4.6 \%$ & $3.1 \%$ \\
\hline & \multirow[t]{3}{*}{ disagree } & Count & 16 & 1 & 17 \\
\hline & & \% within E01 & $94.1 \%$ & $5.9 \%$ & $100.0 \%$ \\
\hline & & $\%$ within A04 - Type of Student & $12.2 \%$ & $1.5 \%$ & $8.7 \%$ \\
\hline & \multirow[t]{3}{*}{ slightly disagree } & Count & 28 & 7 & 35 \\
\hline & & \% within E01 & $80.0 \%$ & $20.0 \%$ & $100.0 \%$ \\
\hline & & $\%$ within A04 - Type of Student & $21.4 \%$ & $10.8 \%$ & $17.9 \%$ \\
\hline & \multirow[t]{3}{*}{ neither agree or disagree } & Count & 14 & 14 & 28 \\
\hline & & \% within E01 & $50.0 \%$ & $50.0 \%$ & $100.0 \%$ \\
\hline & & $\%$ within A04 - Type of Student & $10.7 \%$ & $21.5 \%$ & $14.3 \%$ \\
\hline & \multirow[t]{3}{*}{ slightly agree } & Count & 39 & 13 & 52 \\
\hline & & \% within E01 & $75.0 \%$ & $25.0 \%$ & $100.0 \%$ \\
\hline & & $\%$ within A04 - Type of Student & $29.8 \%$ & $20.0 \%$ & $26.5 \%$ \\
\hline & \multirow[t]{3}{*}{ agree } & Count & 19 & 23 & 42 \\
\hline & & \% within E01 & $45.2 \%$ & $54.8 \%$ & $100.0 \%$ \\
\hline & & $\%$ within A04 - Type of Student & $14.5 \%$ & $35.4 \%$ & $21.4 \%$ \\
\hline & \multirow[t]{3}{*}{ strongly agree } & Count & 12 & 4 & 16 \\
\hline & & $\%$ within E01 & $75.0 \%$ & $25.0 \%$ & $100.0 \%$ \\
\hline & & $\%$ within A04 - Type of Student & $9.2 \%$ & $6.2 \%$ & $8.2 \%$ \\
\hline \multirow[t]{3}{*}{ Total } & & Count & 131 & 65 & 196 \\
\hline & & $\%$ within E01 & $66.8 \%$ & $33.2 \%$ & $100.0 \%$ \\
\hline & & $\%$ within A04 - Type of Student & $100.0 \%$ & $100.0 \%$ & $100.0 \%$ \\
\hline
\end{tabular}

Chi-Square Tests

\begin{tabular}{|c|c|c|c|}
\hline & Value & $\mathrm{df}$ & $\begin{array}{l}\text { Asymp. Sig. (2- } \\
\text { sided) }\end{array}$ \\
\hline $\begin{array}{l}\text { Pearson Chi-Square } \\
\text { Likelihood Ratio } \\
\text { Linear-by-Linear Association } \\
\mathrm{N} \text { of Valid Cases }\end{array}$ & $\begin{array}{r}23.676^{\mathrm{a}} \\
24.960 \\
4.118 \\
196\end{array}$ & $\begin{array}{l}6 \\
6 \\
1\end{array}$ & $\begin{array}{l}.001 \\
.000 \\
.042\end{array}$ \\
\hline
\end{tabular}

a. 2 cells $(14.3 \%)$ have expected count less than 5 . The minimum expected count is 1.99 .

Symmetric Measures

\begin{tabular}{|ll|r|r|}
\hline & & \multicolumn{1}{|c|}{ Value } & Approx. Sig. \\
\hline Nominal by Nominal & Phi & .348 & .001 \\
& Cramer's V & .348 & .001 \\
N of Valid Cases & & 196 & \\
\hline
\end{tabular}




\section{E05 * A05}

E05 * A05 - Education Status Crosstabulation

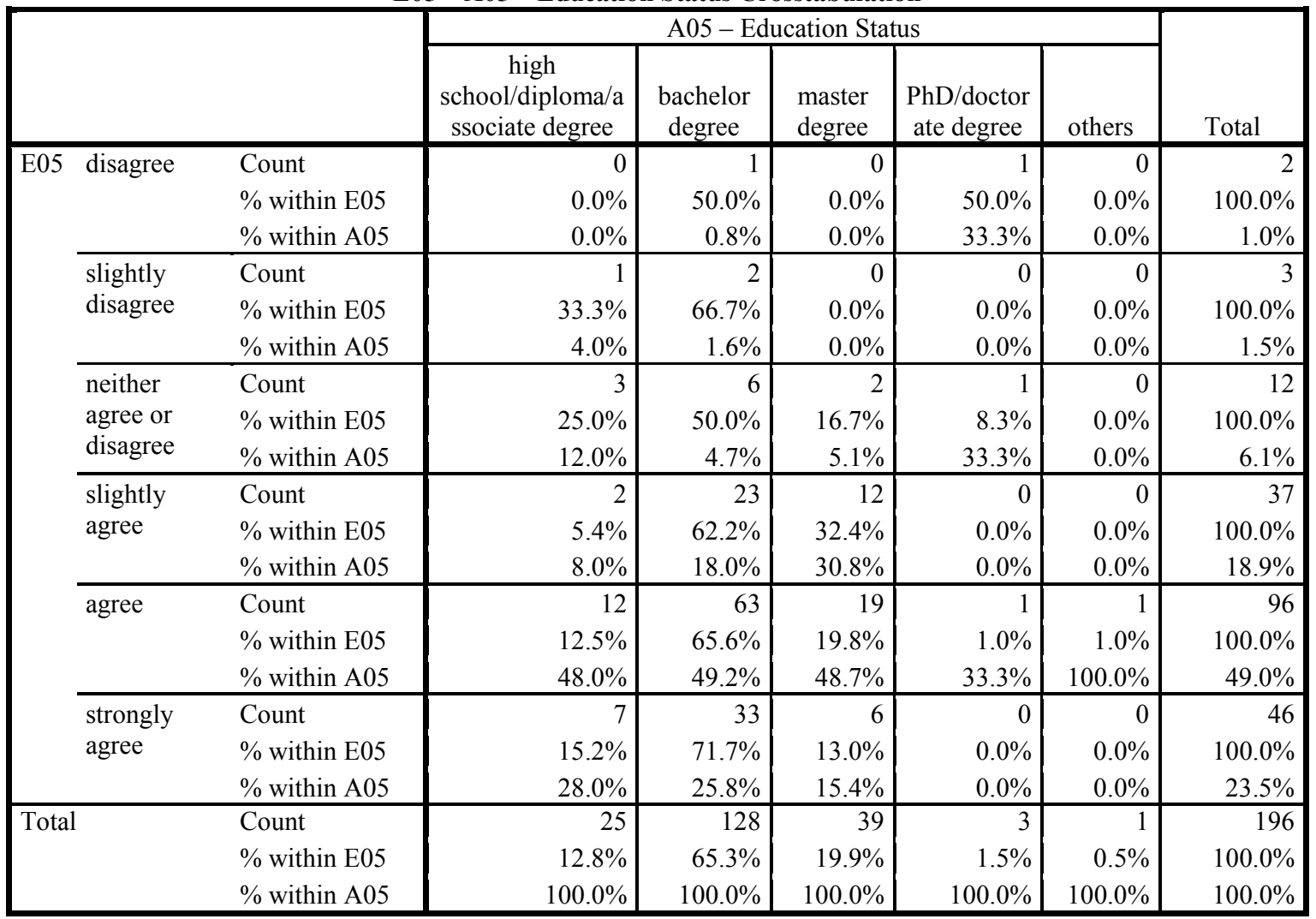

Chi-Square Tests

\begin{tabular}{|l|r|r|r|}
\hline & & & \multicolumn{2}{|c|}{$\begin{array}{c}\text { Asymp. Sig. (2- } \\
\text { sided) }\end{array}$} \\
\hline Pearson Chi-Square & Value & df & .001 \\
Likelihood Ratio & $27.204^{\mathrm{a}}$ & 20 & .332 \\
Linear-by-Linear Association & 2.602 & 20 & .107 \\
N of Valid Cases & 196 & 1 & \\
\hline
\end{tabular}

a. 21 cells $(70.0 \%)$ have expected count less than 5 . The minimum expected count is .01 .

Symmetric Measures

\begin{tabular}{|ll|r|r|}
\hline & & \multicolumn{1}{|c|}{ Value } & Approx. Sig. \\
\hline Nominal by Nominal & Phi & .491 & .001 \\
& Cramer's V & .245 & .001 \\
N of Valid Cases & & 196 & \\
\hline
\end{tabular}




\section{E05 * A06}

E05 * A06 - Type of Company Crosstabulation

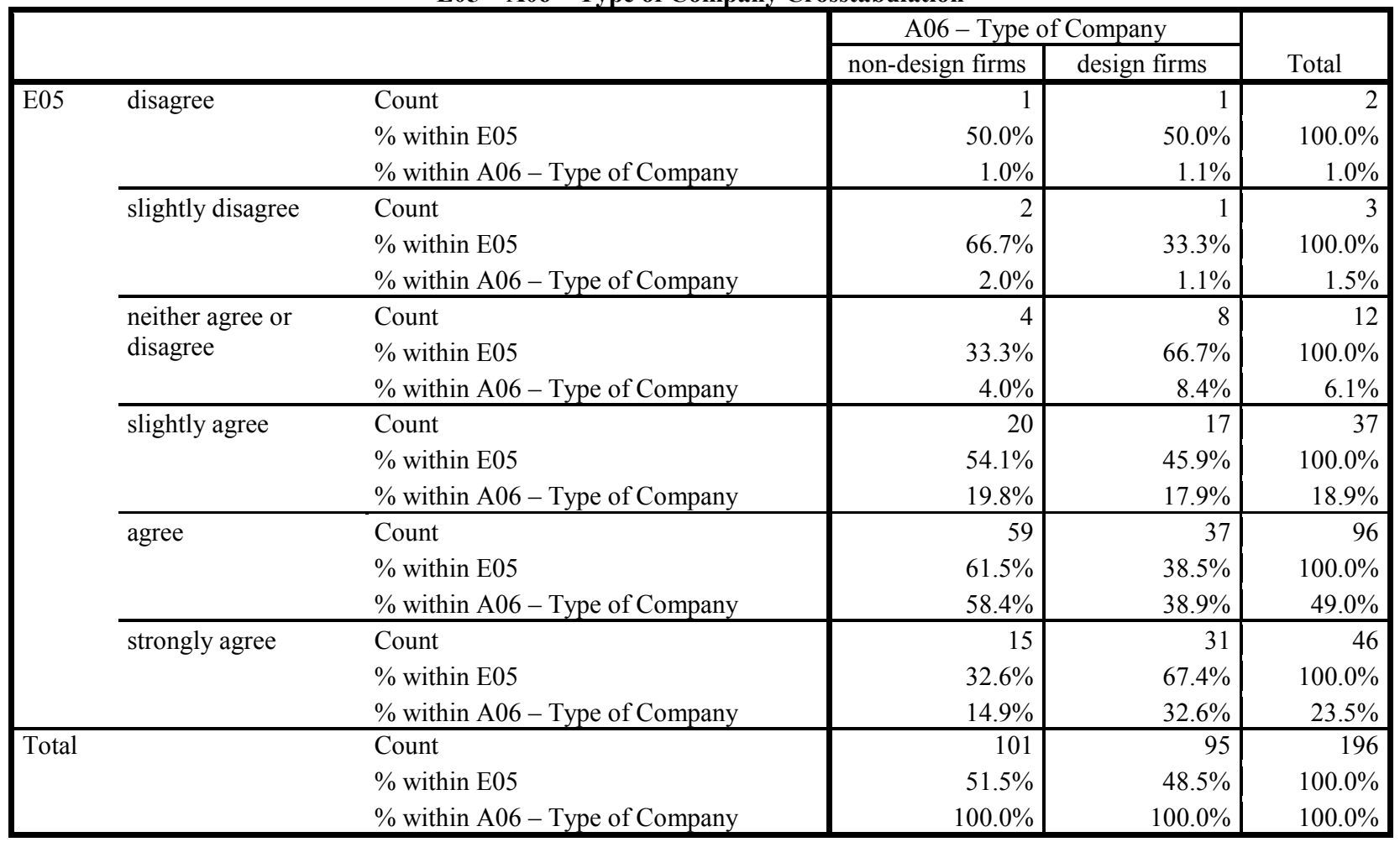

Chi-Square Tests

\begin{tabular}{|c|c|c|c|}
\hline & Value & df & $\begin{array}{l}\text { Asymp. Sig. (2- } \\
\text { sided) }\end{array}$ \\
\hline $\begin{array}{l}\text { Pearson Chi-Square } \\
\text { Likelihood Ratio } \\
\text { Linear-by-Linear Association } \\
\mathrm{N} \text { of Valid Cases }\end{array}$ & $\begin{array}{r}12.345^{\mathrm{a}} \\
12.529 \\
.914 \\
196\end{array}$ & $\begin{array}{l}5 \\
5 \\
1\end{array}$ & $\begin{array}{l}.030 \\
.028 \\
.339\end{array}$ \\
\hline
\end{tabular}

a. 4 cells $(33.3 \%)$ have expected count less than 5 . The minimum expected count is .97 .

Symmetric Measures

\begin{tabular}{|ll|r|r|}
\hline & & \multicolumn{1}{|c|}{ Value } & Approx. Sig. \\
\hline Nominal by Nominal & Phi & .251 & .030 \\
& Cramer's V & .251 & .030 \\
N of Valid Cases & & 196 & \\
\hline
\end{tabular}




\section{E06 * A05}

\section{E06 * A05 - Education Status Crosstabulation}

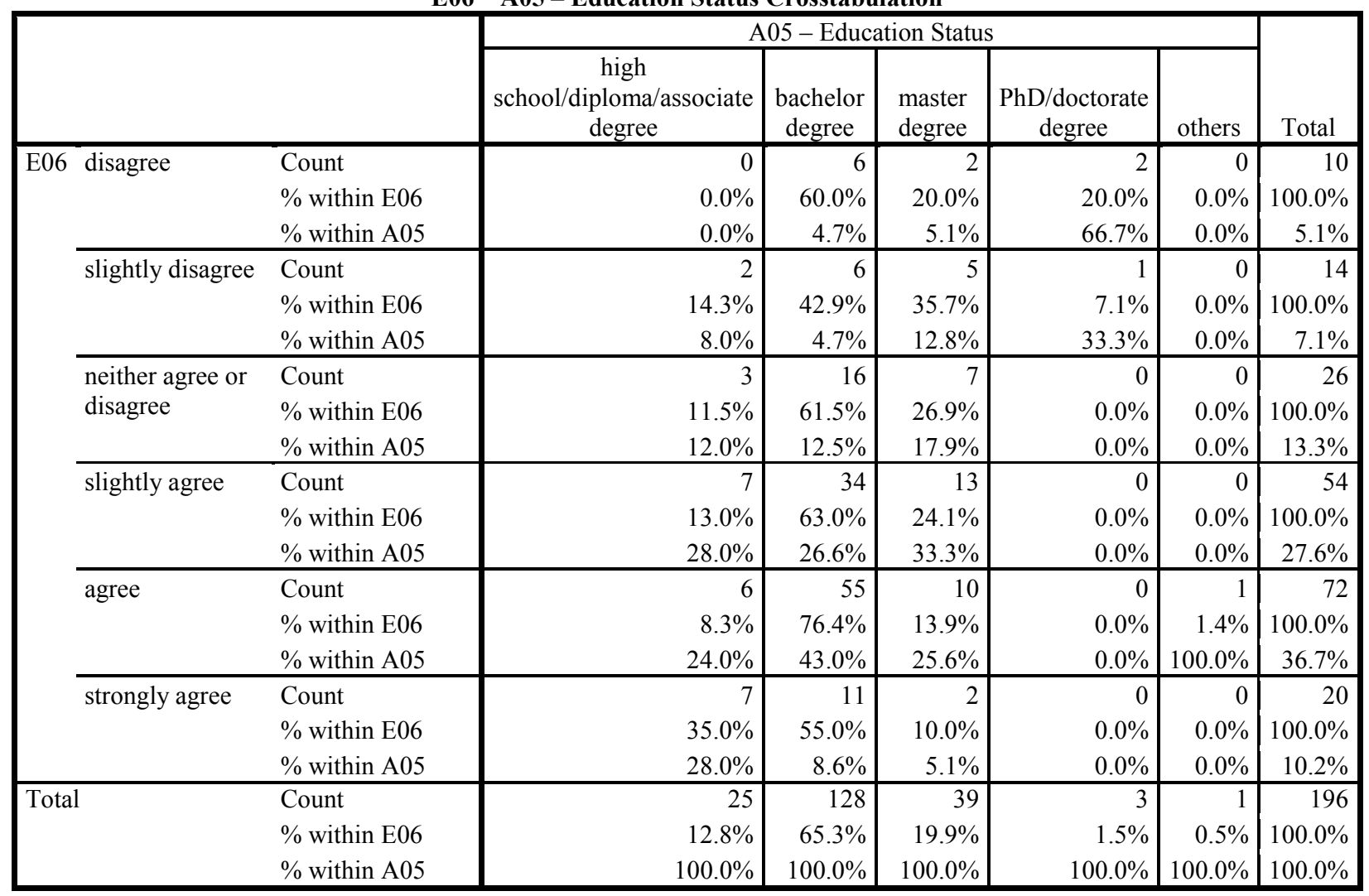

Chi-Square Tests

\begin{tabular}{|l|r|r|r|}
\hline & & & \multicolumn{2}{|c|}{$\begin{array}{c}\text { Asymp. Sig. (2- } \\
\text { sided) }\end{array}$} \\
\hline Pearson Chi-Square & Value & df & .000 \\
Likelihood Ratio & $47.793^{\mathrm{a}}$ & 20 & .037 \\
Linear-by-Linear Association & 32.586 & 20 & .001 \\
N of Valid Cases & 10.853 & 1 & \\
\hline
\end{tabular}

a. 19 cells $(63.3 \%)$ have expected count less than 5 . The minimum expected count is .05 .

Symmetric Measures

\begin{tabular}{|ll|r|r|}
\hline & & \multicolumn{1}{|c|}{ Value } & Approx. Sig. \\
\hline Nominal by Nominal & Phi & .494 & .000 \\
& Cramer's V & .247 & .000 \\
N of Valid Cases & & 196 & \\
\hline
\end{tabular}




\section{E08* A01}

E08 * A01 - Gender Crosstabulation

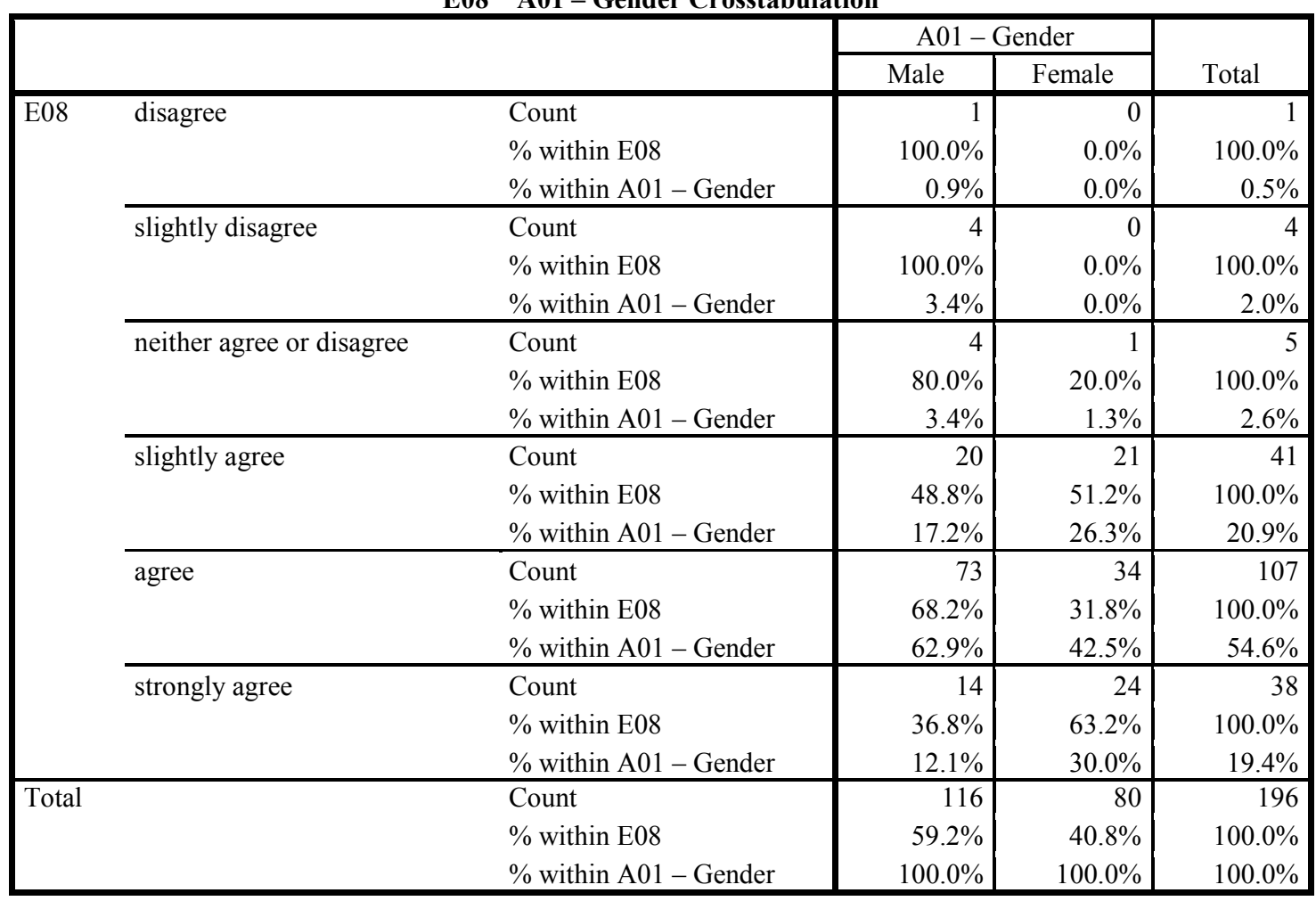

\section{Chi-Square Tests}

\begin{tabular}{|c|c|c|c|}
\hline & Value & $\mathrm{df}$ & $\begin{array}{l}\text { Asymp. Sig. (2- } \\
\text { sided) }\end{array}$ \\
\hline $\begin{array}{l}\text { Pearson Chi-Square } \\
\text { Likelihood Ratio } \\
\text { Linear-by-Linear Association } \\
\text { N of Valid Cases }\end{array}$ & $\begin{array}{r}17.654^{\mathrm{a}} \\
19.444 \\
4.626 \\
196\end{array}$ & $\begin{array}{l}5 \\
5 \\
1\end{array}$ & $\begin{array}{l}.003 \\
.002 \\
.031\end{array}$ \\
\hline
\end{tabular}

a. 6 cells $(50.0 \%)$ have expected count less than 5 . The minimum expected count is .41 .

Symmetric Measures

\begin{tabular}{|ll|r|r|}
\hline & & \multicolumn{1}{|c|}{ Value } & Approx. Sig. \\
\hline Nominal by Nominal & Phi & .300 & .003 \\
& Cramer's V & .300 & .003 \\
N of Valid Cases & & 196 & \\
\hline
\end{tabular}




\section{E08* A05}

\section{E08 * A05 - Education Status Crosstabulation}

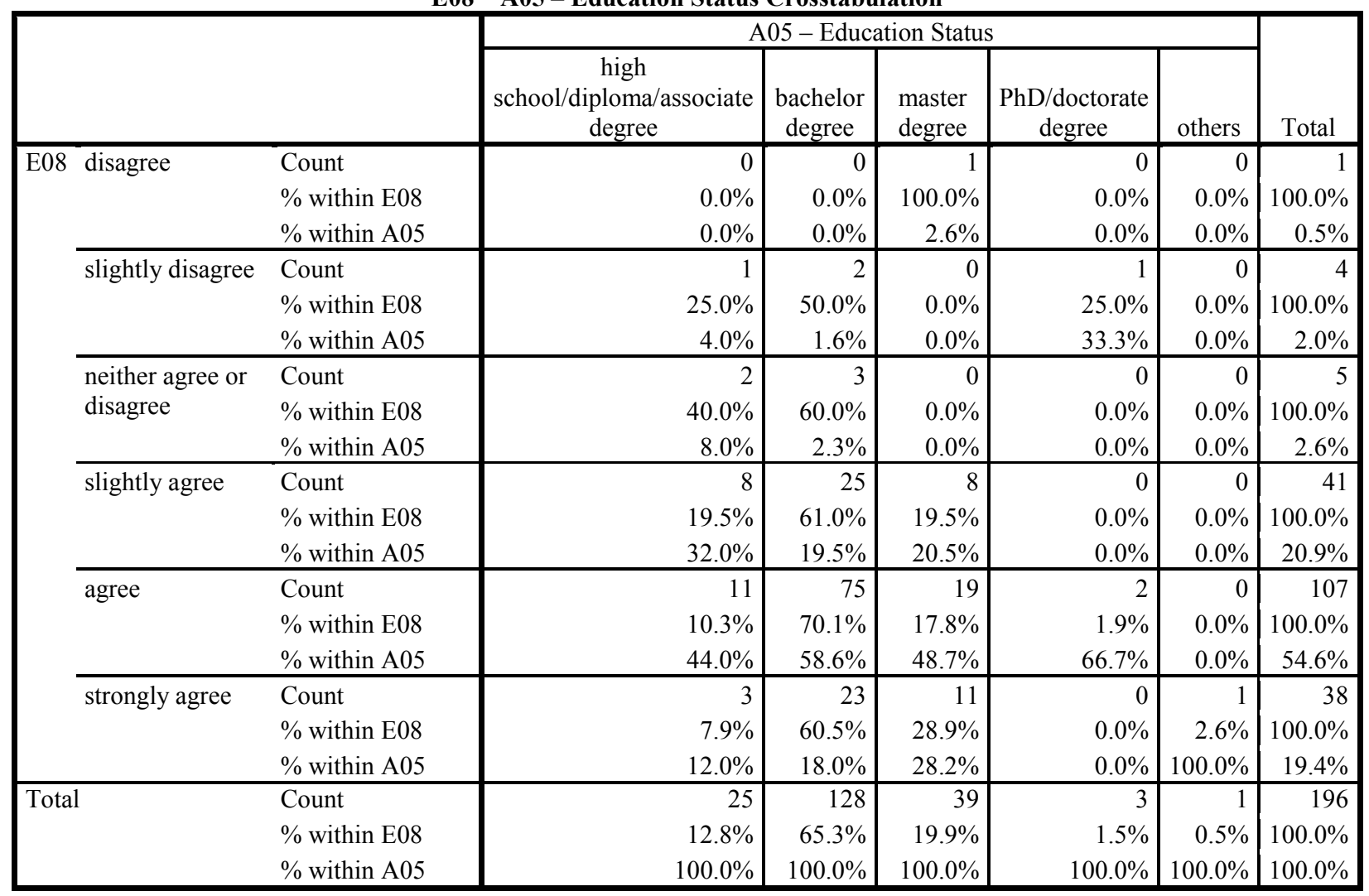

Chi-Square Tests

\begin{tabular}{|l|r|r|r|}
\hline & & & \multicolumn{2}{|c|}{$\begin{array}{c}\text { Asymp. Sig. (2- } \\
\text { sided) }\end{array}$} \\
\hline Pearson Chi-Square & Value & df & .024 \\
Likelihood Ratio & $34.399^{\mathrm{a}}$ & 20 & .255 \\
Linear-by-Linear Association & 23.707 & 20 & .147 \\
N of Valid Cases & 2.100 & 1 & \\
\hline
\end{tabular}

a. 22 cells $(73.3 \%)$ have expected count less than 5 . The minimum expected count is .01 .

Symmetric Measures

\begin{tabular}{|ll|r|r|}
\hline & & \multicolumn{1}{|c|}{ Value } & Approx. Sig. \\
\hline Nominal by Nominal & Phi & .419 & .024 \\
& Cramer's V & .209 & .024 \\
N of Valid Cases & & 196 & \\
\hline
\end{tabular}




\section{E09*A05}

\section{E09* A05 - Education Status Crosstabulation}

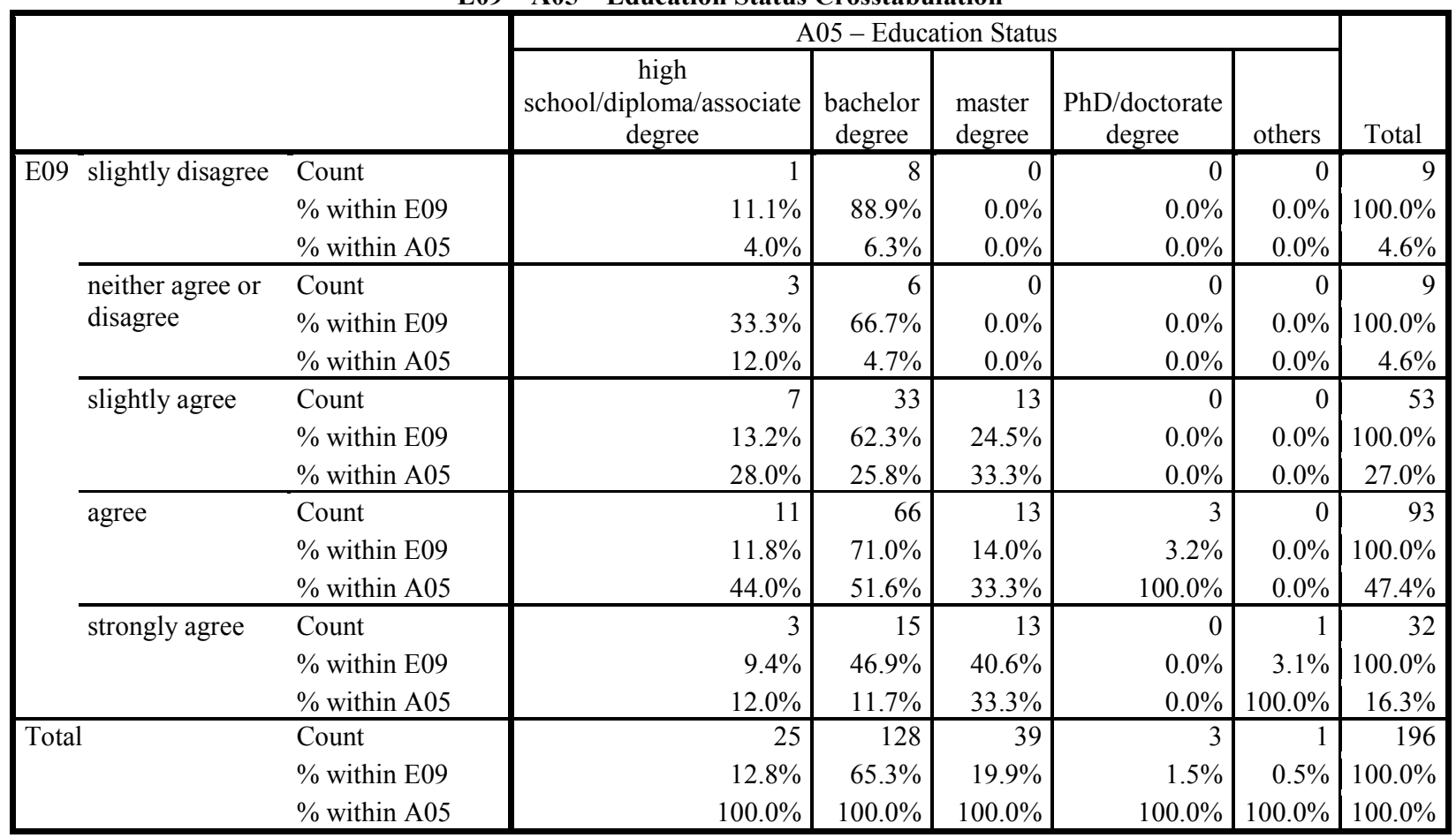

Chi-Square Tests

\begin{tabular}{|l|r|r|r|}
\hline & Value & df & \multicolumn{2}{|c|}{$\begin{array}{c}\text { Asymp. Sig. (2- } \\
\text { sided) }\end{array}$} \\
\hline Pearson Chi-Square & $27.477^{\mathrm{a}}$ & 16 & .036 \\
Likelihood Ratio & 28.441 & 16 & .028 \\
Linear-by-Linear Association & 7.431 & 1 & .006 \\
N of Valid Cases & 196 & & \\
\hline
\end{tabular}

a. 15 cells $(60.0 \%)$ have expected count less than 5 . The minimum expected count is .05 .

Symmetric Measures

\begin{tabular}{|ll|r|r|}
\hline & & \multicolumn{1}{|c|}{ Value } & \multicolumn{1}{c|}{ Approx. Sig. } \\
\hline Nominal by Nominal & Phi & .374 & .036 \\
& Cramer's V & .187 & .036 \\
N of Valid Cases & & 196 & \\
\hline
\end{tabular}




\section{E14 * A02}

E14 * A02 - Age Crosstabulation

\begin{tabular}{|c|c|c|c|c|c|c|c|}
\hline & & & \multicolumn{4}{|c|}{ A02-Age } & \multirow[b]{2}{*}{ Total } \\
\hline & & & $\begin{array}{c}23<\text { years } \\
\text { old }\end{array}$ & $\begin{array}{c}\text { 23-26 years } \\
\text { old }\end{array}$ & $\begin{array}{c}27-30 \text { years } \\
\text { old }\end{array}$ & $>30$ years old & \\
\hline \multirow[t]{21}{*}{ E14 } & \multirow[t]{3}{*}{ strongly disagree } & Count & 1 & 1 & 3 & 1 & 6 \\
\hline & & \% within E14 & $16.7 \%$ & $16.7 \%$ & $50.0 \%$ & $16.7 \%$ & $100.0 \%$ \\
\hline & & $\%$ within A02 - Age & $3.1 \%$ & $1.1 \%$ & $7.1 \%$ & $2.9 \%$ & $3.1 \%$ \\
\hline & \multirow[t]{3}{*}{ disagree } & Count & 1 & 3 & 7 & 0 & 11 \\
\hline & & \% within E14 & $9.1 \%$ & $27.3 \%$ & $63.6 \%$ & $0.0 \%$ & $100.0 \%$ \\
\hline & & $\%$ within A02 - Age & $3.1 \%$ & $3.4 \%$ & $16.7 \%$ & $0.0 \%$ & $5.6 \%$ \\
\hline & \multirow[t]{3}{*}{ slightly disagree } & Count & 6 & 17 & 8 & 8 & 39 \\
\hline & & \% within E14 & $15.4 \%$ & $43.6 \%$ & $20.5 \%$ & $20.5 \%$ & $100.0 \%$ \\
\hline & & $\%$ within A02 - Age & $18.8 \%$ & $19.5 \%$ & $19.0 \%$ & $22.9 \%$ & $19.9 \%$ \\
\hline & \multirow{3}{*}{$\begin{array}{l}\text { neither agree or } \\
\text { disagree }\end{array}$} & Count & 5 & 19 & 8 & 4 & 36 \\
\hline & & \% within E14 & $13.9 \%$ & $52.8 \%$ & $22.2 \%$ & $11.1 \%$ & $100.0 \%$ \\
\hline & & $\%$ within A02 - Age & $15.6 \%$ & $21.8 \%$ & $19.0 \%$ & $11.4 \%$ & $18.4 \%$ \\
\hline & \multirow[t]{3}{*}{ slightly agree } & Count & 7 & 28 & 10 & 7 & 52 \\
\hline & & \% within E14 & $13.5 \%$ & $53.8 \%$ & $19.2 \%$ & $13.5 \%$ & $100.0 \%$ \\
\hline & & $\%$ within A02 - Age & $21.9 \%$ & $32.2 \%$ & $23.8 \%$ & $20.0 \%$ & $26.5 \%$ \\
\hline & \multirow[t]{3}{*}{ agree } & Count & 11 & 17 & 3 & 13 & 44 \\
\hline & & \% within E14 & $25.0 \%$ & $38.6 \%$ & $6.8 \%$ & $29.5 \%$ & $100.0 \%$ \\
\hline & & $\%$ within A02 - Age & $34.4 \%$ & $19.5 \%$ & $7.1 \%$ & $37.1 \%$ & $22.4 \%$ \\
\hline & \multirow[t]{3}{*}{ strongly agree } & Count & 1 & 2 & 3 & 2 & 8 \\
\hline & & \% within E14 & $12.5 \%$ & $25.0 \%$ & $37.5 \%$ & $25.0 \%$ & $100.0 \%$ \\
\hline & & $\%$ within $\mathrm{A} 02-\mathrm{Age}$ & $3.1 \%$ & $2.3 \%$ & $7.1 \%$ & $5.7 \%$ & $4.1 \%$ \\
\hline \multirow{3}{*}{\multicolumn{2}{|c|}{ Total }} & Count & 32 & 87 & 42 & 35 & 196 \\
\hline & & \% within E14 & $16.3 \%$ & $44.4 \%$ & $21.4 \%$ & $17.9 \%$ & $100.0 \%$ \\
\hline & & $\%$ within A02 - Age & $100.0 \%$ & $100.0 \%$ & $100.0 \%$ & $100.0 \%$ & $100.0 \%$ \\
\hline
\end{tabular}

Chi-Square Tests

\begin{tabular}{|l|r|r|r|}
\hline & & & \multicolumn{2}{|c|}{$\begin{array}{c}\text { Asymp. Sig. (2- } \\
\text { sided) }\end{array}$} \\
\hline Pearson Chi-Square & \multicolumn{1}{|c|}{ Value } & df & .026 \\
Likelihood Ratio & 30.856 & 18 & .030 \\
Linear-by-Linear Association & .087 & 18 & .768 \\
N of Valid Cases & 196 & 1 & \\
\hline
\end{tabular}

a. 12 cells $(42.9 \%)$ have expected count less than 5 . The minimum expected count is .98 .

Symmetric Measures

\begin{tabular}{|ll|r|r|}
\hline & & \multicolumn{1}{|c|}{ Value } & Approx. Sig. \\
\hline Nominal by Nominal & Phi & .400 & .026 \\
& Cramer's V & .231 & .026 \\
N of Valid Cases & & 196 & \\
\hline
\end{tabular}




\section{E16 * A02}

E16 * A02 - Age Crosstabulation

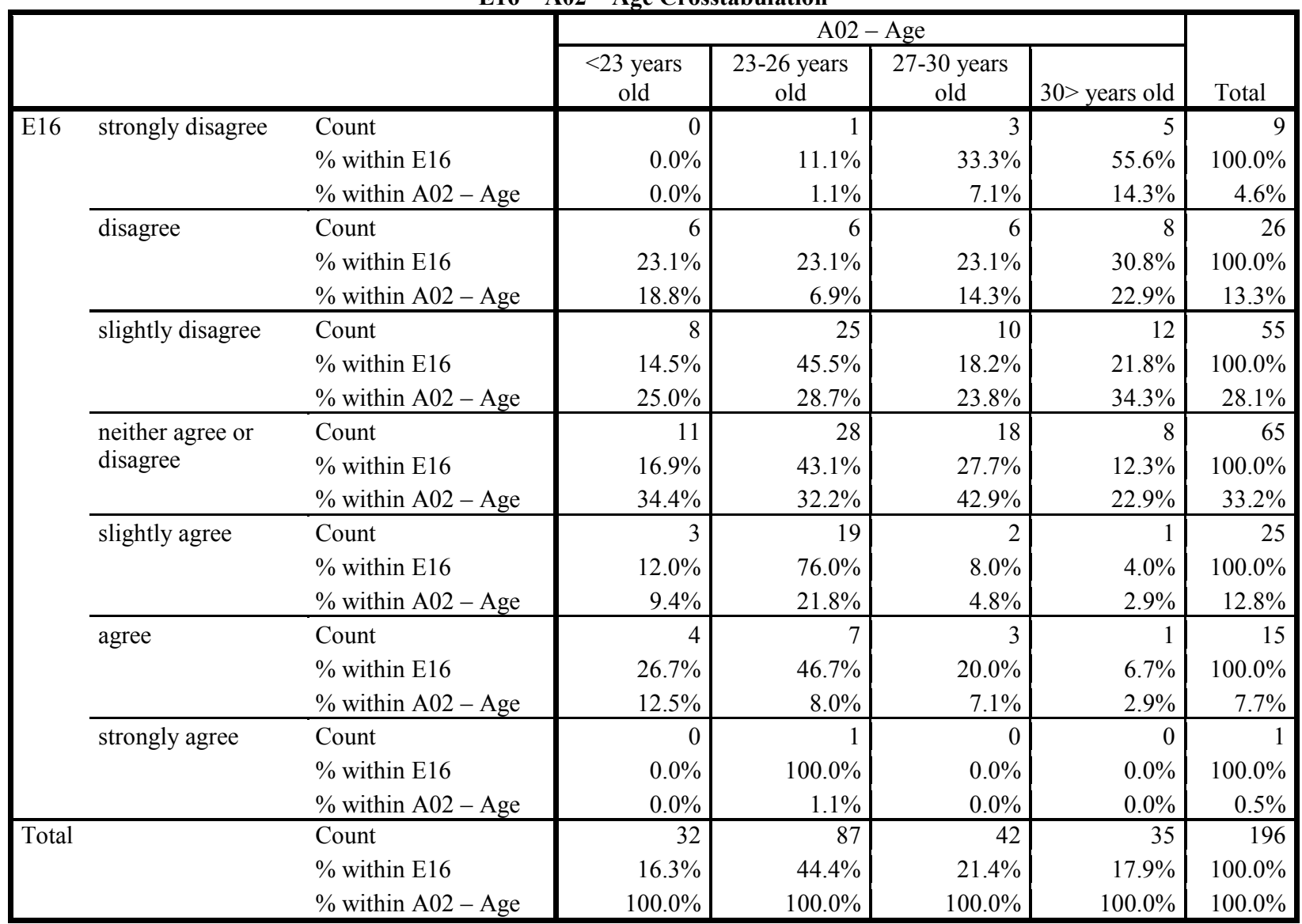

Chi-Square Tests

\begin{tabular}{|l|r|r|r|}
\hline & & & \multicolumn{2}{|c|}{$\begin{array}{c}\text { Asymp. Sig. (2- } \\
\text { sided) }\end{array}$} \\
\hline Pearson Chi-Square & Value & df & .011 \\
Likelihood Ratio & $34.570^{\mathrm{a}}$ & 18 & .007 \\
Linear-by-Linear Association & 35.898 & 18 & .000 \\
N of Valid Cases & 14.005 & 1 & \\
\hline
\end{tabular}

a. 15 cells $(53.6 \%)$ have expected count less than 5 . The minimum expected count is .16 .

Symmetric Measures

\begin{tabular}{|ll|r|r|}
\hline & & \multicolumn{1}{|c|}{ Value } & Approx. Sig. \\
\hline Nominal by Nominal & Phi & .420 & .011 \\
& Cramer's V & .242 & .011 \\
N of Valid Cases & & 196 & \\
\hline
\end{tabular}

